\title{
Between the Local and the National: The Free Territory of Trieste, "Italianita," and the Politics of Identity from the Second World War to the Osimo Treaty
}

\author{
Fabio Capano
}

Follow this and additional works at: https://researchrepository.wvu.edu/etd

\section{Recommended Citation}

Capano, Fabio, "Between the Local and the National: The Free Territory of Trieste, "Italianita," and the Politics of Identity from the Second World War to the Osimo Treaty" (2014). Graduate Theses,

Dissertations, and Problem Reports. 5312.

https://researchrepository.wvu.edu/etd/5312

This Dissertation is protected by copyright and/or related rights. It has been brought to you by the The Research Repository @ WVU with permission from the rights-holder(s). You are free to use this Dissertation in any way that is permitted by the copyright and related rights legislation that applies to your use. For other uses you must obtain permission from the rights-holder(s) directly, unless additional rights are indicated by a Creative Commons license in the record and/ or on the work itself. This Dissertation has been accepted for inclusion in WVU Graduate Theses, Dissertations, and Problem Reports collection by an authorized administrator of The Research Repository @ WVU.

For more information, please contact researchrepository@mail.wvu.edu. 


\title{
Between the Local and the National: the Free Territory of Trieste, "Italianità," and the Politics of Identity from the Second World War to the Osimo Treaty
}

\section{Fabio Capano}

Dissertation submitted to the Eberly College of Arts and Sciences at West Virginia University

in partial fulfillment of the requirements for the degree of

Doctor of Philosophy in Modern Europe

\author{
Joshua Arthurs, Ph.D., Co-Chair \\ Robert Blobaum, Ph.D., Co-Chair \\ Katherine Aaslestad, Ph.D. \\ James Siekmeier, Ph.D. \\ Antonio Varsori, Ph.D.
}

Department of History

Morgantown, West Virginia, 2014

Keywords: Italianità, Free Territory of Trieste, Osimo, Identity, Cold War, Adriatic Border, Irredentism, Zone B, Post-war Italy,

Nationalism

Copyright 2014, Fabio Capano 


\section{ABSTRACT}

\section{Between the Local and the National: the Free Territory of Trieste, "Italianità," and the Politics of Identity from the Second World War to the Osimo Treaty}

\section{Fabio Capano}

This dissertation examines the politicized use of the city of Trieste and its surrounding territory, a cosmopolitan municipality that became the theatre of one of the most heated disputes of the early Cold War years. Scholars have extensively studied the diplomatic dimension of the confrontation between Italy and former Yugoslavia, yet many have largely neglected the significance of the broader political process that led to the Osimo Treaty of 1975, the final settlement of Italy's eastern border. This dissertation reaffirms the importance of the Triestine territory as a contested sociopolitical space that experienced the logic of both Cold War containment and détente. It studies this issue through a pericentric interpretative framework and demonstrates that the intertwining effect of local, national, and international politics significantly impacted the strategy of the Italian government which both extended and moderated the confrontational rhetoric of the Cold War against Tito's regime.

I argue that political leaders, parties, and associations used a wide range of political, economic, and social activities, which I later refer to as the politics of identity, to claim Italian sovereignty over the contested Adriatic border and reassert the Italian identity or "Italianità" of the Triestine territory. Above all, these activities were instrumentally used by the central government to reinforce popular support and project the image of the Triestine territory as a stronghold of Western democracy and barrier to Slav-Communism. Thus, ideas that had previously underscored the Italian identity of the disputed border now took a more dynamic as well as political and economic meaning that increasingly detached from former notions of an "imagined community" which shared a common language, culture, and past. As a result, Cold War Trieste gradually transformed into a factory of ideas of nationhood in post-war Italy.

While this dissertation initially traces the fluctuating meaning of "Italianità" from nineteenthcentury irredentism to twentieth-century Fascism, it later explores government support of nationalist ambitions that survived the Second World War and only gradually adjusted to the dynamic logic of the Cold War. After Trieste's return to Italy in 1954, however, the new Center-left Christian Democratic coalition government reframed its politics of identity toward the city and its territory by upholding a policy of Adriatic friendship that promoted political and economic cooperation across the border. While these policies mirrored the new logic of Adriatic détente, they also met political and popular opposition inside Trieste, ultimately weakening local loyalty toward the nation-state and facilitating the re-emergence of both political localism and autonomist aspirations. The political process that accompanied the definition of Italy's northeastern frontier also reshaped the image of the Triestine border that, located at the Southern point of the Iron Curtain, transformed from a wall into a bridge toward the Communist world. Thus, this work sheds light on the politics of identity in Cold War regions, the dynamic relationship between capital and frontier cities and the fluidity of nationhood in post-war Italy. 


\section{Table of Contents}

Acknowledgements

Introduction

Chapter 1: "Italianità" on the Border: Trieste and Italian Irredentism from National

Unification to the Republic

Chapter 2: From Occupation to the London Memorandum 1945-1954: Trieste's Broken

Statehood and Contested "Italianità" on the Eastern Border

Chapter 3: After London: Re-Thinking Border Politics 1954-1962

Chapter 4: Trieste's Red Years: the Last Breath of Adriatic Irredentism 


\section{Acknowledgments}

The seeds of this project were first planted in my mind in the Fall of 2009 when Dr. Robert Blobaum asked "What happened to Adriatic irredentism?" To respond to his query I undertook the study of one of the most acclaimed irredentist goals: making Trieste Italian. Since then, this study has evolved and transformed into a political history of Italy's eastern border during the Cold War. To attempt to acknowledge all of the help I have received over the years seems almost impossible and here I can only partially express the gratitude that I owe to so many wonderful people that I have met during my studies as a Graduate Student at West Virginia University as well as during my archival research.

My most profound thanks go to my mentors who have trained me as a historian: Dr. Joshua Arthurs and Dr. Robert Blobaum. They have seen this project grow over the years and have given me confidence and guidance from the beginning. Their remarkable suggestions, comments, and expertise have been invaluable. I cannot express my gratitude for their intellectual stimulation, personal encouragement, and patience in proof reading and editing this project. I also owe an enormous thanks to the other members of this Dissertation Committee. Dr. Katherine Aaslestad has always been incredibly supportive and her expertise in nineteenth-century Europe has greatly helped me better understand Trieste's historical trajectory. Likewise, this project has greatly benefited from both Dr. James Siekmeier's expertise in the Cold War and Dr. Antonio Varsori's vast knowledge of post-war Italy in international politics.

I am especially grateful to scholars who I have met during my academic studies and conferences for their thoughtful comments and suggestions. Since my experience as an undergraduate student at University of Trento, Dr. Mark Gilbert has represented a continuous source of inspiration and constant support to my interest in history. I have also greatly benefited from my conversations with Italian scholars of the border who have expanded my understanding of the Adriatic region, among them Raoul Pupo, Roberto Spazzali, Anna Millo, Massimo Bucarelli, Elsa Damien, and Giuseppe Parlato. I am also grateful to young scholars with whom I have shared my research interests and exchanged ideas, among them Dr. Diego D'Amelio and Mirjana Morosini. In Trieste, I own a special thanks to Ravel Kodric for his input on Triestine politics and former Christian Democrat Giorgio Tombesi for making his private papers available and giving his time to be interviewed.

This dissertation would not have been possible without the financial support of the Department of History during my research in both American and Italian archives. Particular thanks go to my fellow graduate students at WVU as well as the faculty, staff, and Chair of the Department. I would also like to thank the personnel at numerous libraries and archives. The staff of the Library of Congress and the National Archives in Maryland has been particularly helpful. I also would like to sincerely thank the staff of the State Archives in Rome as well as the State and Municipal Archives in Trieste. In Rome, I especially would like to thank the personnel of the Office of the Border Zones and its archivist, Dr. Stefania Mariotti, the Historical Archive of the Ministry of Foreign Affairs, the Gramsci Institute, the Luigi Sturzo Institute, the Ugo Spirito Foundation, the Nenni Foundation, the Historical Archives of the Chamber of Deputies and the Senate, the Italian Army Archive, as well as the National Library. In Trieste, I would like to thank the personnel of the Archive of the Local Dioceses and the Coloni family for granting me access to Sergio Coloni's papers. I also would like to thank the personnel and archivists of the Attilio Hortis Library, the Archives of local associations such as the National League and the Istrian Union, as well as the local Institute for the Istrian Culture and the Institute for the History of the Liberation Movement in 
the Friuli Venetian Region. In Trento, I would like to give special thanks to the personnel of the History Museum Foundation.

I also must acknowledge my family and friends for their constant support and encouragement. My parents and my grandmother deserve special recognition for having always been supportive of my studies and research, even when it has taken me far away. Along with them, special thanks go to the Vester family for its support since I first arrived in Morgantown and many friends who have shared my experience as graduate and international students at WVU, above all Alessandro, Michelangelo, and Niki.

The one debt, however, which I must acknowledge beyond all other, is to my wife, Danielle. From Morgantown to Rome, Malatya to Washington DC, she has patiently put up with the research and writing of this dissertation which has uninterruptedly accompanied our first years as a married couple. Her input over the past few years has been very helpful. This dissertation is for her. 


\section{Abbreviations Used in the Main Text}

AMG Allied Military Government

AMI Associazione Mazziniana Italiana (Italian Mazzinian Association)

ANC Associazione Nazionale Combattenti (War Veteran National Association)

ANII Associazione Nazionale Italia Irredenta (National Italian Irredentist Association)

ANTT Associazione Nazionale Trento Trieste (National Association Trento Trieste)

ANVGD Associazione Nazionale Venezia Giulia e Dalmazia (National Association Venetia Julia and Dalmatia)

CIPE Comitato Interministeriale Programmazione Economica (Interministerial Committee for Economic Planning)

CLN Comitato di Liberazione Nazionale (National Liberation Committee)

CNC Centro Nazionale di Coordinamento per la Difesa Zona B e Istria (National Center for the Coordination of the Defense of Zone B and Istria)

DC Democrazia Cristiana (Christian Democratic Party)

EDC European Defense Community

FTT Free Territory of Trieste

LN Lega Nazionale (National League)

LPT Lista per Trieste (List for Trieste)

MSI Movimento Sociale Italiano (Italian Social Movement)

PCI Partito Comunista Italiano (Italian Communist Party)

UAR Ufficio Affari Riservati (The Office of Confidential Affairs)

UI Unione Isriani (Istrian Union)

UZC Ufficio Zone di Confine (Office of Border Zones) 


\section{Abbreviations Used in the Notes}

$\mathrm{AC}$

Archivio Storico Camera dei Deputati (Historical Archives of the Chamber of Deputies)

Archivio Centrale di Stato (Central State Archive)

ACT Archivio Comunale di Trieste (Municipal Archive of Trieste)

AFG Archivio Fondazione Istituto Gramsci (Gramsci Institute Foundation Archive)

ASL Archivio Storico Istituto Luigi Sturzo (Institute Luigi Sturzo Historical Archive)

ASR Archivio Storico Senato della Repubblica (Historical Archive of the Senate)

AST Archivio di Stato Trieste (State Archive of Trieste)

DT Diocesi di Trieste (Diocese of Trieste)

FBIS $\quad$ Foreign Broadcast Information Service

FMSdT Fondazione Museo Storico del Trentino, Trento (History Museum Foundation of Trentino, Trento)

FN Fondazione Nenni (Nenni Foundation)

IRCI Istituto Regionale per la Cultura Istriana (Regional Institute for the Culture of Istria)

IRSML FVG Istituto Regionale per la Storia del Movimento di Liberazione Friuli Venezia Giulia (Regional Institute for the History of the Liberation Movement of FVG)

ISEC Fondazione Istituto per la Storia dell'Età Contemporanea (Institute for the History of the Contemporary Age Foundation)

LC Library of Congress

ALN Archivio Lega Nazionale (Archive of the National League)

NARA National Archives and Records Administration

ASME Archivio Stato Maggiore Esercito Italiano (State Archive Italian Army)

AUI Archivio Unione Istriani (Archive of the Istrian Union)

AUS Archivio Fondazione Ugo Spirito (Ugo Spirito Foundation Archive)

UZC Archivio Ufficio Zone di Confine (The Archive of the Office of Border Zones) 


\section{Introduction}

In November 1968, Italian President Giuseppe Saragat visited Trieste to celebrate the fiftieth anniversary of the armistice ending World War One. This event was locally celebrated with a 55page edition of the Triestine newspaper Il Piccolo and the mass participation of 80,000 veterans. ${ }^{1}$ In his public speech, Saragat portrayed World War One as "the last war of national Risorgimento." Saragat stressed that, in 1918, the image of the Italian soldiers entering Trieste became "the symbol of Italian national unification." ${ }^{2}$ Saragat's speech catered to the endurance of patriotic arguments which traditionally depicted Trieste as the hallmark of Italian irredentist ambitions in the Adriatic.

By 1968, however, these ambitions had been deeply challenged by the events that followed 1945. After the Second World War, indeed, Trieste and northern Istria became symbols of a shattered nation and objects of an international dispute known as the "Trieste Question." ${ }^{3}$ In 1954, the London Memorandum ended the provisional Allied and Yugoslav military occupation of zones A and B of the "Territorio Libero di Trieste" (Free Territory of Trieste, FTT), a planned entity which was never established. At this time, zone A and the city of Trieste returned to Italian administration while Zone B of the FTT (northern Istria) remained under Yugoslav administration. Due to the provisional nature of the agreement, the Italian eastern border remained an unsettled issue for two decades until a solution was finally found with the Osimo Treaty in $1975 .{ }^{4}$ This bilateral treaty established the definitive state border between Italy and Yugoslavia and ended the “Trieste question" almost thirty years after the Paris Peace Treaty of $1947 .^{5}$

\footnotetext{
1“Manifestazione a Trieste per il cinquantenario della Vittoria," Il Secolo d'Italia (November 2, 1968).

${ }^{2}$ Sandro Caputo, "Una solenne e significativa commemorazione: il cinquantenario della Vittoria celebrato da Saragat a Trieste," Il Popolo (November 5, 1968).

${ }^{3}$ See Diego De Castro, La questione di Trieste: l'azione politica e diplomatica italiana dal 1943 al 1954 (2 vols), (Trieste: Lint, 1981).

${ }^{4}$ See Massimo Bucarelli, La “Questione jugoslava” nella politica estera dell'Italia Repubblicana,1945-1999 (Roma: Aracne, 2008).

${ }^{5}$ Trieste's experience is not unique in its genre, yet no other cities of a comparable strategic, political, and economic value came to find themselves entangled in such a context of prolonged ideological and ethnic rivalry. For a study of the post-1947 partition of the Italian city of Gorizia between Italy and Yugoslavia see Chiara Sartori, "Strong Identities: Localism and Nationalism in Gorizia" (PhD diss., Brown University, 2012). For studies of other European cities that became objects of dispute between bordering states especially after WWII, see Bartosz Nabradalik, "South-Eastern Poland between 1939 and the Final Soviet Frontier Demarcation in 1951-The Destruction of an Ethnic Mosaic."Journal of Slavic Military Studies 21(2008): 17-37 and Mark Mazower, Salonica, City of Ghosts:Christians, Muslims, and Jews 1430-1950 (New York: Random House, 2006).
} 
Nonetheless, within the context of the Cold War political leaders, parties and associations continued to claim the Italian identity or "Italianità" of Trieste and its Istrian region to reassert territorial sovereignty over Italy's northeastern border and, especially, maximize popular support for their different causes. These multiple political actors at both the national and local level pursued a wide range of political, economic, and social activities that, later referred to as the politics of identity, utilized national identity as a "political resource which could be modified, manipulated, and functionalized." ${ }^{6}$ Thus, ideas of "Italianità" as a "subjective dimension of self-projection by the local and national community," also took on malleable meanings which reinforced, challenged, or disrupted twentieth-century nationalist rhetoric. ${ }^{7}$ In drawing on Sabina Donati's interpretation of "Italianità" as "the collective phenomenon of national belonging, sometimes distinguishable from, more often blurred with, other identities of the self," this dissertation suggests that "Italianità" can be best understood as a dynamic rather than static territorial or cultural expression of national identity and investigates its political use in post-war Italy through the lenses of the border dispute over Trieste and its territory. ${ }^{8}$

In studying the Free Territory of Trieste, this work contributes to scholarly debates on three main issues. First, it investigates the politics of identity in border zones during the Cold War. In drawing on recent approaches which have shifted the focus from the diplomatic towards the social, political, and cultural dimension of the conflict, it highlights the influential role that Cold War ideology played in shaping both local and national views of the Yugoslav neighbor. ${ }^{9}$ Although scholars have extensively studied the "Trieste Question" as an issue of Cold War diplomacy, only a

\footnotetext{
${ }^{6}$ Gian Enrico Rusconi (ed.), Nazione, etnia,cittadinanza in Italia e in Europa. Per un discorso storico-culturale (Brescia: Editrice La Scuola, 1993), 26. For a similar approach which investigates the ephemeral essence of idea of nationhood in modern Italy see Gino Bedani and Haddock, B.A. (ed.), The Politics of Italian National Identity: a Multidisciplinary Perspective (Cardiff: University of Wales Press, 2001).

${ }^{7}$ See Silvana Patriarca, Italian Vices: Nation and Character from the Risorgimento to the Republic (Cambridge: University Press, 2010).

${ }^{8}$ See Sabina Donati, A Political History of National Citizenship and Identity in Italy 1861-1950 (Stanford: University Press, 2013).

${ }^{9}$ See Tobias Hochscherf, Christoph Laucht, and Andrew Plowman (ed.), Divided but not Disconnected: German Experiences of the Cold War (New York: Berghahn Books, 2010).
} 
few have examined its long-term significance and political implications for Italy, especially after 1954.

As Sabina Mihelj demonstrates, Italians in Trieste effectively thought of those living across the demarcation line as uncivilized, atheist, and "Slavo-Communists." 10 This stereotype, which recalled past views of a "civilized" Western Europe and barbaric Eastern Europe, strongly affected the representation of the "Slav" in and outside the border city of Trieste. Above all, I argue that this Cold War mapping reinforced both nationalist claims of "Italianità" and the symbolic representation of Italy's northeastern border as a bulwark against Yugoslav Communism. As a result, it fueled political antagonism towards Tito's Yugoslavia and hindered the process of Adriatic friendship.

Thus, my work ultimately challenges the idea that after 1954 the Adriatic border transformed into a source of mutual cooperation and understanding and instead emphasizes the prolonged tension that marked political relationships between the Adriatic neighbors and their border communities. At the same time, it also stresses that after 1954 the new Italian Republic gradually adjusted its former Cold War rhetoric to a new strategy of peaceful co-existence with Tito's Yugoslavia. Consequently, symbolic representations of the northeastern Adriatic border vacillated between those of a wall and a bridge, ultimately reframing meanings of national identity.

Second, in studying the complex political relationship between Rome and Trieste, this work contributes to both the study of Italy's northeastern border and, more broadly, to new approaches that emphasize the relationship between center and periphery. In her study of Trieste under Allied Military occupation, Anna Millo investigated the persistent tension between Roman and Triestine political elites during the immediate post-war years. ${ }^{11}$ Although Millo shows that conflicts and misunderstandings effectively debilitated the defense of the city's "Italianità" and facilitated the rise of local political extremism and pro-independence sentiments, her work only partially sheds light on the socio-political dynamics of "Italianità" along the contested Adriatic border. Indeed, its narrow

\footnotetext{
${ }^{10}$ Sabina Mihelj, "Drawing the East-West Border:Narratives of Modernity and Identity in the Northeastern Adriatic (1947-1954)," in Cold War Cultures: Perspective on Eastern and Western European Societies, ed. Annette Vowinckel, Marcus M.Payk, and Thomas Lindenberger (New York: Berghahn Books, 2012), 276-296.

${ }^{11}$ See Anna Millo, La Difficile intesa. Roma e Trieste nella questione giuliana 1945-1954 (Trieste: Italo Svevo, 2011).
} 
focus on the interaction between national and local political elites minimizes the pivotal role that the local public spheres played to support, oppose, and ultimately challenge politicized representations of national identity. This dissertation aims to fill this scholarly lacuna by investigating why and how the interaction between political elite and agents of the Triestine public sphere ultimately re-shaped the twentieth-century territorial meaning of Italian identity between 1945 and 1975.

Finally, this dissertation revises former influential historiographical interpretations of Italian nationalism as a political and cultural movement. ${ }^{12}$ Indeed, much of the current scholarship on this topic suggests that nationalist ideas of Italian identity disappeared in post-war Italy and political actors turned to the European myth of unity. ${ }^{13}$ Contrary to this interpretation, I argue that nationalist understandings of "Italianess" survived after 1945 and were strongly tied to the values of national patriotism and anti-Communism. ${ }^{14}$ Because of its location on the edge of the Adriatic iron curtain, various political actors imbued Italian rule over Trieste and its territory with an irredentist meaning of "Italianità." As Maura Hametz has demonstrated, national and local politicians strove to extend Italian statehood to Trieste and then to preserve it, yet their strategies were challenged by Trieste's cosmopolitan past and ambivalent political identity. ${ }^{15}$

At the same time, however, the new Republic's political elites forged an innovative understanding of national identity which, especially in frontier cities like Trieste, became connected to the values of Western democracy, anti-Communism, and modernization. Although nationalist expressions of Italian identity sporadically re-emerged in the 1960s and 1970s, nationalist definitions of "Italianità" decisively weakened after the city's return to Italian sovereignty in 1954. From that moment, "Italianess" from the perspective of Trieste gradually transformed into a complex social, political, and economic concept that measured the state's ability to fulfill promises

\footnotetext{
${ }^{12}$ See Emilio Gentile, La Grande Italia: ascesa e declino del mito della nazione nel ventesimo secolo (Milano: Mondadori, 1997).

${ }^{13}$ See Nicholas Doumanis, Inventing the Nation: Italy (New York: Oxford University Press, 2001).

${ }^{14}$ See Ariella Verrocchio, Trieste tra ricostruzione e ritorno all'Italia (1945-1954) (Trieste: Irsml, 2004).

${ }^{15}$ See Maura Hametz, Making Trieste Italian, 1918-1954 (New York: Royal Historical Society, 2005).
} 
of economic prosperity and protect the cultural and linguistic Italian identity of the border. ${ }^{16}$ Over time, the failing strategies of the central government facilitated the re-emergence of Trieste's past cosmopolitanism and political autonomy. Thus, Trieste, which was the first Italian city to experience both the ideological confrontation of the Cold War and the process of international detente, offers an invaluable window into popular and political understandings of post-war "Italianità."

This study strongly relies on a variety of primary sources from Italian and American archives, in particular the rich documentation of the Border Office in Rome which has only recently been made available. In closely investigating the Italian government's economic contribution to the Triestine economy, its financial support to the local neo-irredentist network and its defense of the rights of Italian émigrés from the region, this dissertation disputes common arguments regarding the government's indifference to Trieste and instead emphasizes the role that the elastic meaning of "Italianità" played in shaping governmental policies.

This work methodologically approaches the Triestine case by stressing its specificities yet is aware of the danger of over-estimating the significance of the local. ${ }^{17}$ As a study of identity politics and their negotiation between center and periphery, this dissertation explains the relationship between public opinion and political action. ${ }^{18}$ Therefore, it explores popular responses to state policies by means of governmental records, the daily press, official documents of political parties, and the records of émigré and patriotic associations, as well as private papers of leading political figures in order to assess the historical trajectory of Anderson's notion of "imagined communities" in Trieste. ${ }^{19}$

\footnotetext{
${ }^{16}$ For a similar approach to this issue see Roberto Dedenaro, "Postfazione: potersi sentire italiani: un percorso nell'identità italiana di Trieste," in Gli italiani dell'Adriatico orientale: esperienze politiche e cultura civile, ed. Lorenzo Nuovo e Stelio Spadaro (Gorizia: Libreria Editrice Goriziana, 2012), 329.

${ }^{17}$ Luigi Ganapini, Anche l'uomo doveva essere di ferro: classe e movimento operaio a Trieste nel secondo dopoguerra (Roma: Franco Angeli, 1986), 1.

${ }^{18}$ Geoff Eley and Ronald Suny, Becoming National (New York: Oxford University Press, 1996), 24.

${ }^{19}$ See Benedict Anderson, Imagined Communities (London: Verso, 1983).
} 
The examination of this abstract and constructed public space in which people recognized each other as members of the same community were firmly related to notions of common language, culture, and historical past. ${ }^{20}$ These values underscored local irredentist ambitions to first extend and later preserve "Italianità" in Trieste and the Istrian territory. Over time, liberal, fascist, and Republican elites, indeed, promoted a set of images, symbols, and values to demonstrate the voluntary and natural participation of the Italian border community in the life of the nation. Although ideas of membership and loyalty to the same national community remained central to post-war neo-irredentist propaganda, they also became blended with the cosmopolitan and local identity of Trieste after 1954.

In Chapter One I define Adriatic irredentism as a complex politically and socially constructed phenomenon that asserted the region's historical rights to cultural and linguistic autonomy. These views shaped local ideas of "Italianità" that advocated municipal rule rather than territorial separation from the Habsburg Empire. In the early twentieth century, however, loyalty to the Habsburgs was compromised and eventually contradicted by the rise of modern nationalism. ${ }^{21}$ Therefore, on the eve of the Great War, irredentist thinkers decisively re-conceptualized Italianess in ethno-territorial terms and decisively changed the cosmopolitan attitude of fractions of the Italian- speaking population in Trieste. The historical experience of national Fascism conferred a chauvinist and aggressive meaning to "Italianità," ultimately producing phenomena of south Slavic ethno-political retribution after Mussolini's fall in 1943. In such a context, however, ideas of democratic patriotism were rescued by the Triestine Committee of National Liberation which embodied Risorgimental ideas of "Italianità."

\footnotetext{
${ }^{20}$ Alberto Banti, La nazione del Risorgimento: parentela, sanità, e onore alle origini dell'Italia unita (Torino: Giulio Einaudi, 2000), 150.

${ }^{21}$ For a comprehensive historiographic study of the nationalist views of Attilio Tamaro and municipal views of Fabio Cusin, see Silvano Cavazza e Giuseppe Trebbi, Attilio Tamaro e Fabio Cusin nella storiografia triestina: atti del convegno in ricordo di Arduino Agnelli, Trieste, 15-16 Ottobre 2005 (Trieste: Deputazione di Storia Patria per la Venezia Giulia, 2007).
} 
The second chapter investigates the effect of the Cold War on local understanding of national identity. ${ }^{22}$ It studies the ethno-ideological dimensions of the border dispute that materialized on the southeastern edge of the Iron Curtain, which was depicted within the national public sphere as a moment of confrontation between Italian and Slav civilizations and between democracy and Communism. Throughout the chapter, I show that nationalist rhetoric still significantly affected the views of the Republic's new governing elite which consistently attempted to reassert Italian rule over the pre-war Adriatic borders. The views of the immediate postwar Italian government largely mirrored those of the Italian community in and outside Trieste yet were confronted by both the Communist and Triestine independence political movements. After years of diplomatic negotiations, Allied military government, and socio-political violence, the Italian government ultimately complied with the terms of the London Memorandum of 1954, a solution dictated by the imperative of international Cold War politics.

In the third chapter, I examine post-1954 "Italianità" through the lenses of the local economic crisis, the phenomenon of the émigrés, and the activities and propaganda of the neoirredentist network. Although neo-irredentist understandings of "Italianità" had effectively weakened within national public discourse, they continued to dominate in Trieste. At the same time, neo-irredentist associations of democratic rather than nationalist inspiration continued to benefit from the economic and political support of the central government. Nevertheless, the failure of the new Italian administration to respond to the deep economic and social crisis that gripped the city undermined the strength of its patriotic rhetoric and ultimately aroused local animosity toward Rome.

Chapter Four investigates the complex relationship between local interpretations of "Italianità" and the political experiment of the Center-Left coalition governments at the national level between 1963 and 1968. At this time, the central government definitively abandoned any

\footnotetext{
${ }^{22}$ For a new approach that studies the dynamics of the Cold War and its effects on people's daily lives see Frank Tallet, "Writing the History of Daily Life in the Cold War," in Daily Lives of Civilians in Wartime Twentieth-Century Europe, ed. Nichola Atkin (London: Greenwood Press, 2008): 141-162.
} 
residual irredentist ambitions in favor of a more progressive and conciliatory policy and embraced the idea of international negotiations to resolve the border dispute with Yugoslavia. Trieste, for its part, opposed the political and economic policies of the Italian government because they were perceived as threats to both its Italian identity and economic interests. What became known as the Hrescak case exposed the continuing strength of anti-Slovene political sentiment within the Italian Triestine community. Likewise, the city's opposition to the government's plan to restore the competitiveness of Trieste's port demonstrated growing popular animosity toward Rome. Searching for a definitive settlement of the eastern border, the central government underestimated the longterm consequences of the Triestine protests which gave further evidence of the weakness of the patriotic rhetoric of "Italianità."

Finally, the last chapter looks at Trieste's response to the Osimo Treaty. Within the context of political relaxation in East-West relations following the Prague Spring, I emphasize the increasing discrepancy between the views of the Christian Democratic led-coalition government and those of significant segments of the Triestine community who strenuously resisted Adriatic detente. Although the border dispute had become a marginal issue within national public opinion, the political costs of renouncing Italy's formal sovereignty over the former Zone B remained significant inside Trieste. Thus, the central government carried out secret negotiations which were facilitated by a set of international and domestic political factors that accelerated the resolution of the border dispute. The deceptive behavior of the Italian government and the economic terms of the Osimo Treaty, however, provoked an unpredictable socio-political backlash at the local level, which led to the victory of the local protest movement "Lista per Trieste" (List for Trieste, LPT) in municipal elections and ultimately exposed the fluid nature of Trieste's Italian and cosmopolitan identity.

This study of the politics of identity over the eastern border in postwar Italy concludes by discussing its long-term legacy in and outside of Trieste. The Julian city, a historical crossing point of Italian, German, and Slav civilizations, effectively maintained an ambivalent national and 
commercial identity that concurrently reinforced patriotic and cosmopolitan sentiments. Thus, centralized representations of "Italianità" became subjects of continuous negotiations that, within public discourse, paralleled the transformation of Trieste from a nineteenth-century outpost of Adriatic irredentism into a twentieth- century center of nationalism first and political regionalism later. Within the broader context of the Cold War, especially, the external projection of the Triestine territory as a source of Western democracy and well-being starkly contrasted with the dictatorial nature of Tito's regime. Thus, Trieste and its territory became symbols of both the policy of containment and détente, ultimately proving the ideological and geographical fluidity of Italy's eastern border. While this political process revealed the intertwining effects of international, national, and local politics, it also shed light on both the resilience of nationalist rhetoric and the new political relationships between frontier cities and their capitals in an age of Cold War. In postwar Italy, it produced a sense of "composed decadence" among Triestines which exposed the complexity, strident contradictions, and legacy of European modernity "from the birth of nationalisms to the profound crisis of the European subject." 23

\footnotetext{
${ }^{23}$ Claudio Minca, "Trieste Nazione and its Geographies of Absence," Social and Cultural Geography 10 (3) (2009):
} 258. 


\section{Chapter One}

\section{"Italianità" on the Border: Trieste and Italian Irredentism from National Unification to the}

\section{Republic}

During the late nineteenth and first half of the twentieth century, Trieste transformed from a Hapsburg to an Italian domain and, together with Trento, became focal points in the myth of an Italian national manifest destiny. ${ }^{1}$ This myth, rooted within the historical experience of the Italian “Risorgimento," was strongly informed by Giuseppe Mazzini’s idea of the nation as a voluntary association of people based on the principle of nationality. ${ }^{2}$ Therefore, in "language frontiers" 3 such as Trieste and its hinterland, the principle of nationality underscored ideas of self-determination as well as membership and mutual loyalty toward Italy's new imagined community.

Adriatic irredentism, a complex cultural, political, and social phenomenon that emerged on the shores of the Adriatic Sea during the nineteenth-century, became the harbinger of a local version of nationhood whose myths, symbols, and images shaped specific notions of Italian identity or "Italianità." Over time, irredentism transformed from the intellectual property of a tiny minority into "a shared experience for people who were conscious of their own identity." 4 At first, irredentist thinkers conceptualized "Italianità" as an expression of cultural and linguistic autonomy within the broader intellectual framework of Adriatic multi-nationalism. "Italianità," however, gradually changed and became a valuable political means to justify the territorial reincorporation of the "unredeemed" land within the borders of the new Italian state. Indeed, during the twentieth century, national identity was increasingly understood in "exclusionary and sometimes xenophobic terms.",5

\footnotetext{
${ }^{1}$ Ara Angelo e Eberhard Kolb, Regioni di frontiera nell'epoca dei nazionalismi: Alsazia e Lorena / Trento e Trieste (Bologna: Il Mulino, 1995), 13.

${ }^{2}$ For a historical examination of the role and values of individualism within Mazzini's thought, see Vetter Cesare e Andrea Stefanel, "Giuseppe Mazzini: felicità, reincarnazionismo e sacralizzazione della politica" Contemporanea: Rivista di Storia dell'800 e del '900 14 (2011) (1): 5-32.

${ }^{3}$ Pieter Judson, Guardians of the Nation: Activists on the Language Frontiers of Imperial Austria (Cambridge, Mass: Harvard University Press, 2006), 11.

${ }^{4}$ Diego Redivo, Le trincee della nazione: cultura e politica della Lega Nazionale (1891-2004) (Trieste: LN, 2004$), 21$.

${ }^{5}$ Dominique Reill, Nationalists who Feared the Nation: Adriatic Multi-Nationalism in Habsburg Dalmatia, Trieste, and Venice (Standford: University Press, 2012), 1.
} 
What scholar Alberto Banti defined as the "nationalizing cosmopolitanism" of Europe's nineteenth-century ideas of nation, inexorably faded on the eve of the Great War. ${ }^{6}$ During the interwar years, the fascist regime ultimately undermined any residual and conciliatory notion of "Italianità" and revealed its most aggressive and chauvinist features. Consequently, Italian language and culture became instruments as well as symbols of repression and imperialism for the Slavic population living along the Adriatic border. It was only in 1943, amidst Mussolini's fall, that a small group of local intellectuals desperately attempted to re-launch Mazzini's idea of national patriotism. Although their efforts remained largely ignored and were overshadowed by the prominent Communist-led movement of local resistance, their legacy contributed to the post-war revival of "Italianità" on the Adriatic border.

\section{Risorgimento and the Dawn of Adriatic Irredentism}

"Carso is the part of the Adriatic region between the eastern side of the Julian Alps (Italy's natural border) and the mountain range that runs through the Triestine gulf, cuts Istria in two distinct halves and reaches the Quarnero."7 With these words, the nineteenth century Triestine writer, Scipio Slapater, described the territory surrounding Trieste and imagined the geographical extension of the Italian Adriatic border. In his biographical narrative, "Il Mio Carso,” Slapater equated Italy to culture, liberty, and economic prosperity. This idea echoed the views of Adriatic irredentists who advocated for Italian territorial rule over Trieste, Istria, and Dalmatia which they believed were Italian in language and culture. ${ }^{8}$

At the beginning of the nineteenth century, however, the Italian-speaking bourgeoisie of Trieste promoted a version of Italian nationhood which recognized the multicultural nature of the city and its indissoluble association to the Austrian empire. ${ }^{9}$ In order to guarantee the opulence of

\footnotetext{
${ }^{6}$ Banti Alberto e Roberto Bizzocchi, Immagini della nazione nell'Italia del Risorgimento (Roma: Carocci Editore, 2002), 14.

${ }^{7}$ Scipio Slapater, Il mio Carso (Milano: Mondadori Editore, 1962), 16.

${ }^{8}$ See Carlo Schiffrer, Le origini dell'irredentismo triestino (1813-1860) (Verona: Del Bianco, 1978).

${ }^{9}$ Angelo Vivante, L'irredentismo adriatico (Trieste: Italo Svevo Edizioni, 1984), 23.
} 
the city, irredentist thinkers advocated the defense of Trieste's Italian cultural autonomy within the imperial public sphere rather than political or territorial separation for the Adriatic city. ${ }^{10}$ Pacifico Valussi, for instance, claimed that "distinct nations formed on the borderlands in conjunction with others nations would secure peace" and would favor socio-political harmonization among neighboring communities. ${ }^{11}$

This specific conceptualization of Trieste's Italian identity underscored ideas of the city as the "Hamburg of the Adriatic," a notion which highlighted its pivotal role within the multicultural, religious, and linguistic network of the maritime region. ${ }^{12}$ It also revealed the prominence of economic over political factors in shaping Italian group identity within the Habsburg framework. Indeed, commercial interests further reinforced cosmopolitanism among the Triestine elites and within the local public sphere for the years that anticipated the "springtime of nations" in $1848 .{ }^{13}$

At this time, a complex set of underground nationalist movements vigorously emerged and contested the multicultural nature of the Adriatic region. While undermining the peaceful coexistence of different national cultures, their propaganda also revealed the urgency of the nationality question within a multi-ethnic Empire such as Austria-Hungary. ${ }^{14}$ Moreover, popular disapproval of extensive taxation, conscription and the ongoing financial crisis, fomented revolutionary upheaval in Trieste. ${ }^{15}$ Anti-Habsburg sentiment, however, was not a clear expression of political separatism; ${ }^{16}$ it was rather a reaction to changes in the nature and scale of international commerce as well as the unequal language policies imposed by Vienna for secondary and higher

\footnotetext{
${ }^{10}$ See Emilio Cocco e Everardo Minardi, Immaginare l'Adriatico: contributo alla riscoperta sociale di uno spazio di frontiera (Milano: Franco Angeli, 2007).

${ }^{11}$ Reill (2012), 111.

${ }^{12}$ Reill (2012),82.

${ }^{13}$ For an account of the Triestine lifestyle during the Hapsburg era, see Silvia Bonucci, Voices From a Time: a Novel (New Hampshire: Steerforth Press, 2006).

${ }^{14}$ Reill (2012),200.

${ }^{15}$ Anna Millo, "Trieste,1830-70:From Cosmopolitanism to Nation," in Different Paths to the Nation, ed. Laurence Cole (New York: Palgrave MacMillan, 2007), 61.

${ }^{16}$ For a description of the events that stresses Trieste's participation to the revolutionary outburst of 1848 see Pacifico Valussi e Constantino Ressman, Trieste e l'Istria e le loro ragioni nella questione italiana (Milano: Libreria Brigola, 1861).
} 
education, viewed by the Habsburg state as a valuable means to achieve greater economic and social integration. ${ }^{17}$

After 1848 and within the context of "Risorgimento," the Italian struggle for national independence, not only elites but also common people were attracted by the promises and activism of nationalist agitators and responded by mobilizing on a local level in expectation of potential material benefits. ${ }^{18}$ In urban centers such as Trieste, the local Italian bourgeoisie attempted to protect its economic privileges and to respond to rising Slav nationalism by negotiating for local administrative autonomy with the Habsburg authorities. ${ }^{19}$ This strategy responded both to Hapsburg paternalistic policies and the gradual rise of pan-Slavism, yet it only partially succeeded. Based on the promotion of nation-building for historically disadvantaged ethnic groups, pan-Slavism "reinforced the national Croatian and Slovenian linguistic and cultural ties, thus limiting the capacities of national integration of the Italian dominant group. ${ }^{, 20}$ As a result, competing nationalisms arose, especially in areas inhabited by a Slavic-speaking majority, such as the rural areas of the Istrian region. ${ }^{21}$

Thus, when the Hapsburg administration refused to accept Italian as the official language of Istria, the Italian Liberal Party produced a memorandum that supported federalism in Trieste, Istria, and Dalmatia. ${ }^{22}$ Such initiatives were supported by local irredentist organizations such as the

\footnotetext{
${ }^{17}$ Gary Cohen, Educational and Middle-Class Society in Imperial Austria 1848-1918 (West Lafayette, Indiana: Purdue University Press, 1996), 9.

${ }^{18}$ On this issue see Alan Confino, The Nation as a Local Metaphor: Wurttemberg, Imperial Germany, and National Memory, 1871-1918 (North Carolina: University Press, 1997). For a broader analysis of the rise of competing nationlaism in a local municipality see Jeremy King, Budweisers into Czechs and Germans: A Local History of Bohemian Politics in 1848-1948 (Princeton: University Press, 2002).

${ }^{19}$ For studies of local and regional identity within the German speaking lands see Celia Applegate, "Localism and the German Bourgeoisie:the Heimat Movement in the Rhenish Palatinate before 1914," in The German Bourgeoisie:Essay on the Social History of the German Middle Class from the late Eighteenth to the Early Twentieth Century, ed. David Blackbourn and Richard J. Evans (New York: Routdlege, 1991), 238. Also see Katherine Aaslestad, Place and Politics. Local Identity, Civic Culture, and German Nationalism in North Germany during the Revolutionary Era (Boston: Brill, 2005).

${ }^{20}$ Vanni D'Alessio, "From Central Europe to the Northern Adriatic: Habsburg Citizens between Italians and Croats in Istria,” Journal of Modern Italian Studies 13(2) (2008): 238.

${ }^{21}$ For regional studies which provide an interesting comparative perspective see David Laven, Venice and Venetia under the Habsburg, 1815-1835 (New York: Oxford University Press, 2002). Luciano Monzali, The Italians of Dalmatia:from Italian Unification to WWI (Toronto:University Press, 2009). Dominique Reill, “A Mission of Mediation: Dalmatia's Multi-national Regionalism from the 1830s-60s," in Different Paths to the Nation, ed. Laurence Cole (New York: Palgrave MacMillan, 2007), 16-36.

${ }^{22}$ Schiffrer, 107.
} 
Triestine Council and the Triestine Society. More importantly, they confirmed the process of gradual politicization of Triestine society whose "municipal myth" had worked as an antidote to Italian nationalism and made Trieste "a city that does not think of itself in territorial terms but as a maritime city, as an Adriatic and Mediterranean cosmopolitan capital." ${ }^{23}$ At the same time, the most intransigent fringes of these organizations gradually began to develop separatist ambitions that took either a specifically liberal or socialist outlook. In claiming the Italian identity of Trieste, segments of the local Triestine bourgeoisie ultimately promoted exclusive solutions to the problem of nationality within the broader Adriatic space. ${ }^{24}$

The majority of the local Italian bourgeoisie, however, remained generally loyal to the Habsburg crown and bargained for political compensations. ${ }^{25}$ In particular, they pursued the defense of Italian commercial interests not only from the centralist policies of the Vienna administration but also from the economic competition of other local minorities. ${ }^{26}$ The city, indeed, attracted a large number of Slovenian peasant migrants from neighboring villages. ${ }^{27}$ In addition, local Slovenes developed their own associational network of banks and cooperatives while seeking political recognition from the Hapsburg administration. These demographic and economic changes significantly affected group identities and were accompanied by increasing ethno-political rivalry in Trieste. $^{28}$

After 1861, the creation of the Italian state strengthened the aspirations of national unification of local irredentist groups, yet the Triestine bourgeoisie still continued to rely on a strategy of political accommodation which better served its commercial interests. Niccolò

\footnotetext{
${ }^{23}$ Minca,261.

${ }^{24}$ Galliano Fogar, Dall'irredentismo alla resistenza nelle provincie adriatiche: Gabriele Foschiatti (Udine: Del Bianco, 1966), 18.

${ }^{25}$ Angelo Ara e Claudio Magris, Trieste: un 'identità di frontiera (Torino: Einaudi, 2007), 55.

${ }^{26}$ Marina Cattaruzza, "Population Dynamics and Economic Change in Trieste and its Hinterland, 1850-1914," in Population and Society in Western European Port-Cities, 1650-1939, ed. Richard Lawton and Robert Lee (Liverpool: University Press, 2002), 179.

${ }^{27}$ See Dean Krmac, "La popolazione di Trieste a metà ottocento. Una prima ricostruzione della topografia dei flussi migratori," Rivista Storica Italiana 119 (2) (2007): 835-895.

${ }^{28}$ Other works on the subject have emphasized the long-term effects of the 1848 bourgeois revolution. For example, see Bojan Baskar, "Raccontare il mare. La ridefinizione delle identita' nazionali nell'Adriatico nord-orientale," ed. Cocco and Minardi, 25-55.
} 
Tommaseo, the most prominent intellectual of Adriatic multi-nationalism, best exemplified the views of the Triestine bourgeoisie. Firmly believing that "variety helps us feel unity" Tommaseo stressed the importance of regional over national identity in ethnically heterogeneous areas such as the Adriatic region. ${ }^{29}$ The Dalmatian intellectual championed the "anational" nature of the Adriatic Littoral and the desirability of federal or confederate solutions, such as a Danubian Confederation, to maximize linguistic and cultural autonomy for its Italian community. ${ }^{30}$

Tommaseo's notions of regional cosmopolitan identity were partially reinforced by the Habsburg Empire's accommodative policies toward the Italian language, which remained unchanged until 1864 when German became compulsory in public schools. Afterwards, the third Italian war of Independence of 1866 drastically changed the ethnic and political configuration of the Venetian region and compounded the Austrian administration's distrust of the Italian community in Trieste and Dalmatia. ${ }^{31}$ In addition, the preservation of Italian, Croatian or Slovenian languages within a segregated school system and Vienna's decision to block local students from attending Italian universities aroused local animosity toward the Hapsburg administration. ${ }^{32}$

In such a context, Trieste increasingly became a micro-cosmic entity that embodied the conflict between Imperial sovereignty and nationalist ambitions. ${ }^{33}$ Consequently, factions of the local Italian bourgeoisie increasingly opposed the dominant role of local German speakers inside the state bureaucracy and embraced separatist strategies. ${ }^{34}$ Not simply political but especially economic changes to the privileged position of Trieste undermined the cosmopolitan attitudes of the Italian local bourgeoisie. ${ }^{35}$ Following the 1860 s crisis in exports to Italian markets, and especially after the 1869 opening of the Suez Canal and the construction of the Trieste-Vienna railway, the

\footnotetext{
${ }^{29}$ Reill (2012), 243.

${ }^{30}$ See Jozè Pirjevec, Niccolò Tommaseo tra Italia e Slavia (Venezia: Marsilio Editori, 1977).

${ }^{31}$ See Map I.

${ }^{32}$ Reill (2012),234.

${ }^{33}$ Carlo Ghisilberti, Adriatico e confine orientale: dal Risorgimento alla Repubblica (Napoli: Edizioni Scientifiche Italiane, 2008), 216.

${ }^{34}$ Anna Millo, "Un porto fra centro e periferia (1861-1918)," in Il Friuli Venezia Giulia, ed. Roberto Finzi, Claudio Magris, e Giovanni Miccoli (Torino: Einaudi, 2002), 204.

${ }^{35}$ Schiffrer, 159.
} 
Map I: the Changing Configuration of Italy's Eastern Border between 1866 and 1947

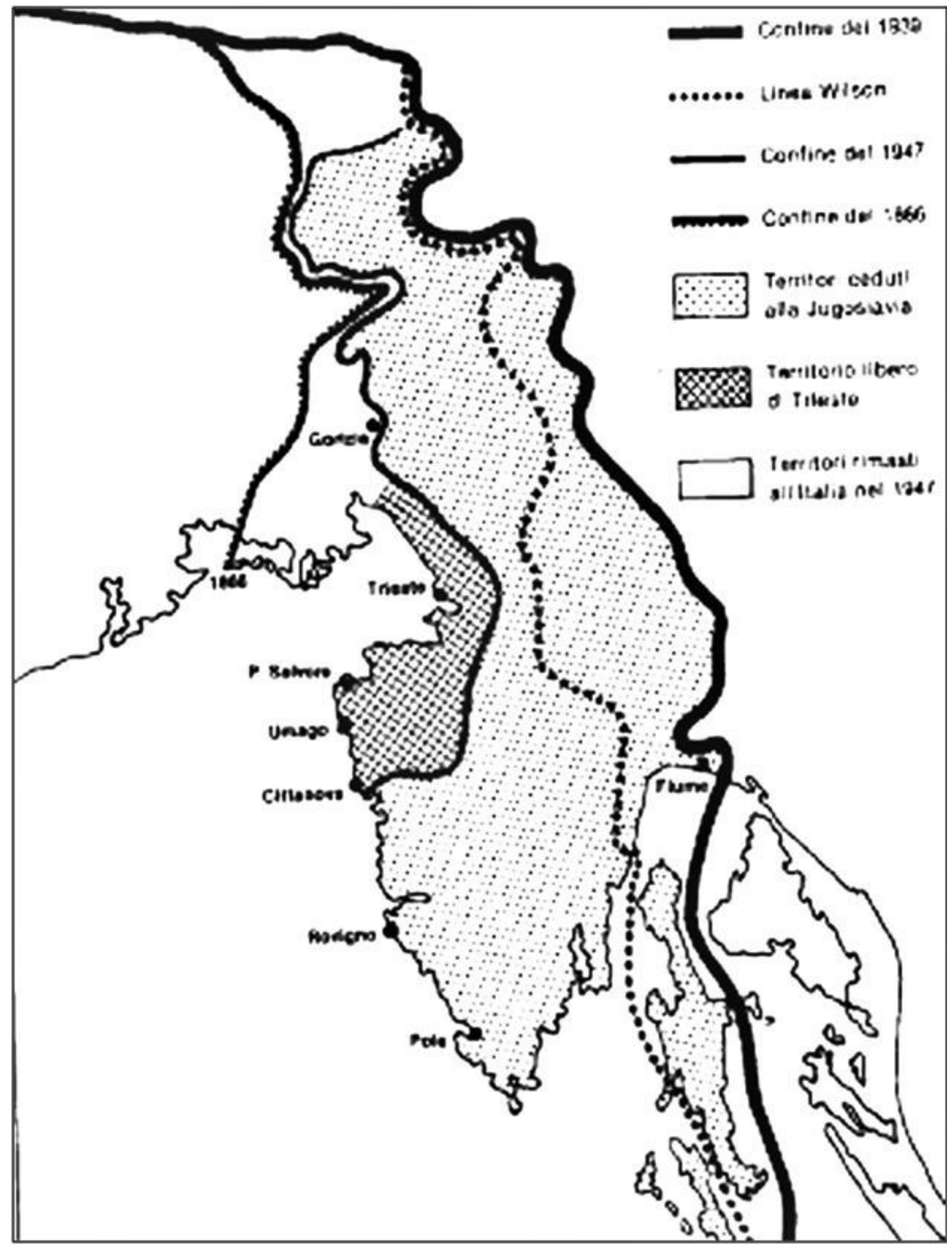


Triestine bourgeoisie claimed that Trieste's role was minimized to that of an obsolete and intermediary port; however, according to Italian scholar Claudio Minca, the Triestine bourgeoisie criticized Vienna's economic policy to obtain further concessions that later allowed "Triestine shipping and insurance companies to expand internationally." ${ }^{36}$ Nonetheless, the transformation of the Triestine port exacerbated the resentment of the Triestine commercial elites who, also responding to the rise of a politically and economically organized Slovenian minority, fatally undermined perspectives of socio-political accommodation.

Despite this, the lack of credibility of the Italian state undermined the local confidence of the Triestine bourgeoisie for the city's territorial incorporation into the new Italian Kingdom. Local Italian communities on the eastern border, indeed, negatively judged the new and amicable Italian foreign policy toward Austria-Hungary and Germany. The Andrassy report of 1874 effectively confirms that the Italian Kingdom intended to accommodate the German interests in the Adriatic in order to pursue expansionist goals in the Mediterranean. ${ }^{37}$ This pro-Austrian policy, hostile to irredentist organizations such as the Committee for Irredentist Italy in Naples formed in 1877, weakened the irredentist movement both inside and outside the Italian borders. In 1882, the formation of the "Triple Alliance" formalized the military alliance between Austria-Hungary, Italy, and Germany and led to the widespread repression of irredentist associations inside Italy. This process culminated in the arrest of Bottera Raimondo, a patriot and founder of the irredentist journal Italia Irredenta.

In response, Millo argues, some Italians in Trieste interpreted these events as a proof that their ambitions for national unification had been "sold out" by Rome, a feeling that survived into the twentieth century. ${ }^{38}$ Above all, the Triestine liberal newspaper of the Italian bourgeoisie, L'Indipendente, openly criticized the Italian government and its rising repression of irredentism as well as the ban on public discourse about the separation of Trento and Trieste from the Habsburg

\footnotetext{
${ }^{36}$ Minca, 264.

${ }^{37}$ Raoul Pupo, Il confine scomparso:saggi sulla storia dell'Adriatico orientale nel novecento (Trieste: Isrml Friuli Venezia Giulia, 2007), 15.

${ }^{38}$ Millo (2011), 216.
} 
Empire. ${ }^{39}$ Although this local newspaper proved critical of Italy's policy toward the eastern border, the new Italian nation was portrayed as the opponent of pan-Slavism and a "symbol of the material and moral civilizing of humanity." ${ }^{40}$ More important, these nationalist arguments threatened Trieste's economic prosperity which strongly depended on its geo-political status within the Habsburg Empire.

\section{Trieste's Turn to the Nation-State}

In Trieste, large segments of the commercial bourgeoisie promoted Italian language and culture without encouraging local political separatism until the late $1800 \mathrm{~s}^{41}$ At this time, however, the city experienced a strong economic crisis that decisively strengthened popular hostility toward Habsburg rule. In a city of 145,000 people of which 136,000 were Italians, fears of Slovene penetration of social state institutions and commercial sectors as well as governmental repression of expressions of self-determination boosted Italian popular nationalism. ${ }^{42}$ As a result, the propaganda of Adriatic irredentists, who had previously advocated Italian cultural autonomy within the Empire, aligned to that of Italian nationalists who were determined to incorporate Trieste within Italy's national borders.

Editions of L'Indipendente of the late 1880s confirmed that a widespread segment of the local population increasingly supported expression of political irredentism. In response to the Austrian ban on the Italian associational network in the Adriatic region and Austrian hostility toward the rights of the Italian students, the latter provoked mass protests inside Hapsburg universities which were promptly suppressed by the Imperial authorities. In addition, popular support for the initiatives of the local branch of the cultural association "Dante Alighieri," revealed the rising momentum of local expressions of Italian identity. ${ }^{43}$

\footnotetext{
${ }^{39}$ L'Indipendente (May 15, 1889).

${ }^{40}$ L'Indipendente (January 20, 1878).

${ }^{41}$ Ara (2007), 78 .

${ }^{42}$ Cattaruzza (2002), 180.

${ }^{43}$ L'Indipendente (September 15, 1888).
} 
L'Indipendente not only highlighted issues of linguistic discrimination but it also emphasized the damage that unfavorable Habsburg policies, such as, the abolition of Trieste's status as a free port and an increase in imports to other urban centers had caused to the economic interests of the local Italian commercial bourgeoisie. ${ }^{44}$ According to Adriatic intellectual Angelo Vivante, the reduced strength of trade, which had been the traditional vehicle of "Italianità" throughout the region, effectively weakened the cosmopolitanism of moderate irredentist factions within the local Triestine bourgeoisie. ${ }^{45}$ Thus, economic complaints compounded with irredentist propaganda against the educational privileges of the local Slav population, and ultimately aroused ethnic tension between the Slavic and Italian communities as well as hostility to Habsburg rule. ${ }^{46}$ Consequently, associations such as "Pro Patria" and especially the "Lega Nazionale" (National League), the leading voice in support of Trieste's Italian identity, gained popular support. ${ }^{47}$ Its impressive growth to 10,000 members symbolized the increasing strength of nationalist orientations among the Italianspeaking population. ${ }^{48}$

Over time, social, political, and economic factors decisively facilitated popular expressions of Adriatic irredentism. In this fashion, the Pirano revolt of 1894 became one of the most celebrated events in the narrative of popular irredentism. Pirano, an Istrian town populated by a small Italian population, was represented in the Diet of the Austrian Littoral. ${ }^{49}$ In response to the compulsory imposition of Italian and German bilinguism, the town's Italians violently revolted against the Habsburg local administration. Despite the nationalist and rhetorical depiction of the revolt, it appears that territorial unification to Italy did not represent the dominant goal among the rebels; rather, support of a Balkan Confederation or a group of independent nations received greater

\footnotetext{
${ }^{44}$ L'Indipendente (November 15, 1888).

${ }^{45}$ Vivante, 260.

${ }^{46}$ According to the newspaper, there were 13 Slovenian schools for a population of approximately 35,000 Slovenians in Trieste. L'Indipendente (July 15, 1892).

${ }^{47}$ See Paolo Sardos Albertini, Lega Nazionale storia di un sodalizio che attraversa tre secoli (Trieste: Lega Nazionale, 2011).

${ }^{48}$ L'Indipendente (December 1, 1892).

${ }^{49}$ See Almerigo Apollonio, Autunno istriano: la rivolta di Pirano del 1894 e i dilemmi dell'irredentismo (Trieste: Edizioni Italo Svevo, 1992).
} 
popular support. ${ }^{50}$ Local Italian associations such as the Istrian Political Society, for example, advocated administrative autonomy for the Italian population living in Istria. ${ }^{51}$

Indeed, arguments of Italy's everlasting cultural attractiveness, were still central to irredentist rhetoric. In claiming that "for each educated person Rome is the mother, for each pious soul Rome is the genesis," irredentists attempted to both relate Trieste's Italian identity and legitimize its inclusion within Italy's borders by means of the cultural heritage of Imperial Rome. ${ }^{52}$ Although some factions of the Triestine elite were still committed to the protection of commercial interests within the Hapsburg imperial framework, their perspective of "Italianità" had indeed deeply changed by the late nineteenth century. ${ }^{53}$

In addition, the inability of the Triestine Liberal Party to respond to the needs of the popular and underprivileged mass of Italians living in the city "made Trieste" one of the unhealthiest towns of the Hapsburg monarchy in pre-1914 period" and gradually weakened popular support for the moderates of this party. ${ }^{54}$ As a consequence, strongly separatist political views inside the city gradually attracted not only larger segments of the local commercial bourgeoisie but also other groups among the local population. ${ }^{55}$ Aware of the rising extremism within the irredentist movement, Italian politicians in Rome also grew increasingly sympathetic to Adriatic irredentism. ${ }^{56}$ In the early twentieth century especially, secessionist ambitions gained further momentum. In a December entry of 1904, L'Indipendente depicted attempts to mobilize student and civil society organizations at Innsbruck University as acts of "efficient and civil vigor" that paralleled the heroic resistance of the "Giovine Trieste" (Young Triestine Association) against German oppression. ${ }^{57}$ Nationalist rhetoric and separatist ambitions also proved particularly strong within local and

\footnotetext{
${ }^{50}$ Apollonio, 159 .

${ }^{51}$ L'Indipendente (April 1, 1895).

${ }^{52}$ L'Indipendente (November 1, 1895).

${ }^{53}$ Marina Cattaruzza, L'Italia e il confine Orientale, 1866-2006 (Bologna: Mulino, 2007), 62.

${ }^{54}$ Cattaruzza (2002), 207.

${ }^{55}$ This argument that relates to the crisis of democratic stances within the irredentist movement and the rise of political nationalism finds further evidence in Elsa Damien, "The Reversal of the Myths: Venetian Historiography and Adriatic Nationalism (1897-1922)," Italy and its Pasts, ASMI annual conference, (19-20 November 2010), 6.

${ }^{56}$ Hametz (2012), 29.

${ }^{57}$ L'Indipendente (December 15, 1904).
} 
national irredentist associations. Among them, the "Associazione Nazionale Trento Trieste" (National Association Trento Trieste, ANTT) became one of the main promoters of Italian territorial rule over both Trento and Trieste.

In 1905, a letter from a member of the association emphasized the strong commitment of the ANTT toward the Italian population living in border regions. It stated that "whereas the association Dante Alighieri embraces the entire world, we modestly pay attention only to our brothers under Austria." ${ }^{58}$ Moreover, the 1908 report highlighted the independence and autonomy of the ANTT from any political affiliation and strongly criticized the clerical tendencies (in Trieste usually perceived as supportive of pan-Slavism) within the association. ${ }^{59}$ In referring to the Venetian local branch of the ANTT and the repressive measures of the Austrian authorities against manifestations of "Italianità" in the school system, the ANTT stressed the necessity to financially support the activism of young monarchists and their press network on the eastern border. ${ }^{60}$

This radical turn inside the Adriatic irredentist movement provoked both resistance and support among traditional irredentist thinkers. For example, in 1909, Slapater argued that the local Italian bourgeoisie in Trieste was unable to overcome the issue of the primacy of economic over political and cultural interests of the Italian speaking population. In exchanges of correspondence published in the newspaper La Voce, Slapater defined irredentism as a cultural phenomenon located within the multicultural soul of Trieste which "was not irredentist." ${ }^{\text {" }}$ Numerous letters in response to Slapater criticized the irredentist thinker for his support of Trieste's ambivalent nationhood which strictly contrasted with the claims of aggressive irredentists who vouched for the extension of

\footnotetext{
${ }^{58}$ Fondazione Museo Storico del Trentino (FMSdT), Fondo Associazione Nazionale Trento Trieste, Busta 6, fasc.1 cc3 (May 25, 1905), 72.

${ }^{59}$ FMSdT, Busta 6, fasc. 1 cc3 (December 16, 1908), 76-85.

${ }^{60}$ FMSdT, Busta 6, fasc. 1 cc3 (November 22, 1909), 142.

${ }^{61}$ Scipio Slapater, Lettere triestine: col seguito di altri scritti vociani di polemica su Trieste (Trieste: Edizioni Deadolibri, 1988), 60.
} 
Italian rule from Trieste to Dalmatia. ${ }^{62}$ These two irreconcilable views of Trieste's national or multinational identity would later polarize future debates about the city’s "Italianità.,"63

By this time, however, uncompromising views increasingly pervaded the irredentist movement. In 1910, in an article entitled "Il Secondo Irredentismo" published within the March edition of the liberal newspaper La Grande Italia, Gualtiero Castellini compared the accomplishments of irredentism in the northeastern and southern regions. Castellini highlighted the necessity of an intellectual and moral regeneration of the nation as a whole which, together with the cultural activity of the "Dante Alighieri," would have achieved the final goal of political irredentism: territorial unification. ${ }^{64}$ Also, in its commentary on the national Congress of the ANTT in Mantua between May 31 and June 1, 1913, La Voce della Patria reported increasingly hostile national public opinion toward Austria-Hungary due to its violation and repression of the rights of the Italian minority and its cultural identity. The Congress recalled the glorious past of Rome and Venice and invoked the political and territorial redemption of the Adriatic lands "for Trento, for Trieste, for a greater Italy inside its own sacred borders. ${ }^{, 65}$ The rising hostility toward the Habsburg Empire found even more resonance in succeeding editions of the journal in 1913 and 1914. The journal fomented anti-Austrian feelings among local and national public opinion and highlighted the mistreatment of the Italian minority within educational institutions, the unfavorable terms of the Italian-Austrian alliance, and the necessity to "take up the sword" against the daily oppressive attitude of German civilization. ${ }^{66}$

In drawing a direct relationship between the cultural heritage of former "Italian" Empires and Trieste's Italian identity, irredentists aimed to foment public hostility toward the repressive rule of Austria-Hungary and strengthen political support for Italy. In a city whose urban population was

\footnotetext{
${ }^{62}$ Slapater (1988), 68.

${ }^{63}$ Such views were well summarized in the antagonist and irreconcible nature of the classless and humanitarian message of social irredentist Cesare Battisti that strictly contrasted to the nationalist, ethnic and imperialist thought of irredentist Ruggero Timeus.

${ }^{64}$ FMSdT, Busta 3, fasc.1, cc 221, La Grande Italia (March 6, 1910).

${ }^{65}$ La Voce della Patria (August 10, 1913).

${ }^{66}$ La Voce Patria (August 31, 1914).
} 
overwhelmingly Italian, the growing presence of Slovenian workers within the local industry as well as the Habsburg curtailment of the traditional commercial privileges of the Triestine bourgeoisie strengthened popular consensus toward the separatist strategy of the Italian local bourgeoisie. ${ }^{67}$ At the same time, however, its prospective solution to the nationality question in the Adriatic clashed with the socialist movement, producing tension on both ethnic and political lines. ${ }^{68}$

During the months anticipating Italy's entry into the First World War the intense propaganda campaign conducted by the new "Associazione Nazionalista Italiana" (Italian Nationalist Association) of 1910 and the ANTT was centered upon the idea of a struggle for survival against hostile German and Slav civilizations. For the ANTT the war was the maximum expression of Italian patriotism and popular ambitions of national unification. Its final goal was “to make Dante's dream possible and to assure that our flag rules over the sea and the shores in which our only language is and always has been spoken."69 This statement effectively mirrored the general orientations of the local Triestine bourgeoisie. In sharp contrast to earlier years, the larger part of this class identified its main interests with the imperialist ambitions of the Italian Kingdom. ${ }^{70}$ Although it responded to the growth of the Italian and Slovene working population by promoting bold views of Trieste's Italian identity, segments of the Italian speaking population retained a traditional cosmopolitanism that after the war re-emerged in the form of local municipalism.

Thus, in drawing a general picture of Adriatic irredentism in Trieste before the outbreak of the Great War, what emerges is the image of an urban center in an agricultural area in which the Italian commercial bourgeoisie gradually gravitated from compromise to open conflict with the German and Slav populations. The ambivalent nature of Trieste's identity was best exemplified by the concurrent myth of cultural Risorgimental independence and the reality of economic

\footnotetext{
${ }^{67}$ As clearly shown by government statistics of the early $1900 \mathrm{~s}$, about 142,000 Italians were present in Trieste while 147,000 were present in Istria. In addition, Fiume counted 26,000 Italians and Dalmatia had a population of 30,000 Italians. Even though by 1910 the Italian population in Trieste declined to 119,000 while the Slovenian population rose to 59,000 people, Italians still represented a significant majority of the total population: $52 \%$ compared to the Slovenian minority of $28 \%$ and, among others, the German, Greek, and Jewish minorities of about 20\%. Hametz (2005),105-106.

${ }^{68}$ For an overview on the relation between the nationality question, working class and socialism within Habsburg lands see Arduino Agnelli, Questione nazionale e socialismo (Bologna: Il Mulino, 1969).

${ }^{69}$ La Voce della Patria (September 27, 1914).

${ }^{70}$ Millo (2002), 227.
} 
dependence on Austria. This contradiction between economic interests and national consciousness put "irredentists against irredentism." ${ }^{, 71}$ Until the 1890s, sentiment toward self-determination among the Italian speaking- population was still in a formative stage and did not yet create a deep breach between the Italian population and Habsburg rulers. By the turn of the century, however, nationalist factions of the Triestine bourgeoisie attacked the Hapsburg bureaucracy and arrogated to themselves the right to ostracize or absorb the local Slav population. Due to the allegedly indisputable "Italianità" of those lands, these local elite rejected traditional Triestine cosmopolitanism and invoked the extension of Italian sovereignty over the Adriatic border.

\section{World War One and Fascism: making Trieste the "Italianissima" City}

It was only on the eve of the Great War that Adriatic irredentism indisputably became "a movement to incorporate irredenta, that is, lands or people represented as unredeemed because stranded under alien rule," and a classic example of homeland nationalism. ${ }^{72}$ It is also during this period that Trieste's disputed identity became object of a prolonged debate between supporters of nationalist notions of "Italianità" and those who advocated Trieste's traditional municipalism within the broader context of a multi-national Adriatic region.

These two conflicting views were best exemplified by the writings of Attilio Tamaro and Fabio Cusin. Tamaro, the most representative irredentist and fascist thinker of twentieth-century Trieste, was a fervent nationalist who championed the "indisputable" Italian identity of the city and drew support for his argument on a biased reading of Trieste's historical past. ${ }^{73}$ Tamaro greatly stressed manifestations of "Italianità" in Trieste in the form of its patriotic associations, press, and Masonic lodges and attributed the failure of patriotic uprisings to strong governmental censorship and repression. These uprisings were explained as the outcome of combined actions of patriots and local liberal elites whose defense of traditional municipal autonomy was connected to the Italian

\footnotetext{
${ }^{71}$ Vivante, 261.

${ }^{72}$ Rogers Brubaker, Nationalism Reframed: Nationhood and the National Question in the New Europe (New York: Cambridge University Press, 1996), 110.

${ }^{73}$ See Attilio Tamaro, Storia di Trieste (Trieste: Edizioni Lint, 1976).
} 
identity of Trieste. Even though Tamaro minimized the complex interconnection between economic interests and cultural identity and never changed his beliefs about the historic "Italianità" of Trieste, he later recognized that "Triestine irredentism had lost most of its romanticism" and had moved dramatically toward more aggressive and nationalist positions since the early 1900 s. $^{74}$

Already in 1915, Tamaro regarded "Italianità" as a natural trait of the city population and dismissed historical rivalry and competition between Venice and Trieste. In line with the overwhelmingly imperialist orientations of national and local irredentism, Tamaro presented the inclusion of Trieste within Italian state borders both as the best means to provide continuity to Venetian past and as a platform for the city's national rebirth. ${ }^{75}$ Tamaro, while highlighting the "anti-patriotic" positions of social democratic segments of the irredentist movement and stressing the problematic ethnic polarization of the city, also celebrated the contribution that high and middle layers of the Triestine society provided to the affirmation of the indisputable Italian identity of the city.

In contrast, Fabio Cusin proclaimed the benefits of Trieste's traditional municipalism. This anti-fascist intellectual of Italian-Jewish origin was born in Trieste during the Habsburg era and wrote extensively during both the inter-war and post-war years, becoming the leading voice of the local Independence Movement. Cusin, in a traditional nineteenth-century Adriatic multi-nationalist outlook, based the historic rights of a nation on cultural and linguistic principles. Moreover, he explained Italian national unification as the outcome of the will of a centralist and despotic entrepreneurial elite who manipulated irredentism for expansionist goals. According to Cusin, given a context such as that of Trieste in which the artificial character of "Italianità" was particularly visible, the myth of national unification greatly relied on the political opportunism of the Triestine bourgeoisie. $^{76}$

At the dawn of the Great War, the ongoing crisis that accompanied the re-conceptualization

\footnotetext{
${ }^{74}$ Attilio Tamaro, Trieste, storia di una città e di una fede (Milano: I.E.I, 1946), 231.

${ }^{75}$ See Attilio Tamaro, L'Adriatico golfo d'Italia l'italianità di Trieste (Milano: Treves, 1915).

${ }^{76}$ See Fabio Cusin, Antistoria d'Italia: una demistificazione della storia ufficiale: un'Italia sotto luce diversa (Milano: Mondadori, 1970).
} 
of "Italianità" on the border was best represented by the bitter diatribes between "Vociani" and the Futurists. While the former highlighted the multicultural nature of Trieste and the strength of its local identity or "Triestinità," the latter stressed that Trieste's geographical location gradually transformed the city into a bulwark of Italian national identity. ${ }^{77}$ In this context, nationalist rhetoric also affected the views of local Triestines and shaped negative perceptions toward the neighbors across the frontier. ${ }^{78}$ The fear of pan-Slavism and the commercial interests of the Italian political establishment in Trieste, Istria and Dalmatia ultimately played an important role in shaping ambivalent local attitudes toward the war which, at the popular level, were mediated by the traditions of Triestine cosmopolitanism..$^{79}$

Although these traditions were weakened and gradually overshadowed by the resonance of nationalist arguments, a significant portion of the Triestine population still supported Austrian rule of Trieste and remained loyal to the Habsburg crown. ${ }^{80}$ Indeed, about 50,000 men of the Italian Adriatic Littoral, served in the Austrian-Hungarian Army while only 1,000 defected in order to serve in the Italian Army. ${ }^{81}$ As these estimates suggest, inside the Venetian Julian region, which was inhabited by approximately 350,000 Italians and 470,000 Slavs, who were unevenly distributed in urban and rural centers, royal loyalty, deep-rooted regional identities, and economic interests reduced the attractiveness of political separatist views among the local Italian population. It also exemplified the problematic overlapping of cultural and newly politicized notions of national identity. Nationalist propaganda and ethno-territorial conceptualizations of "Italianità" in Trieste failed to account for the city's traditional cosmopolitanism and had to compete with its past municipal identity. In addition, nationalist arguments were further challenged by local socialists whose views of Trieste's identity mirrored those of nineteenth-century irredentists.

\footnotetext{
${ }^{77}$ John McCourt, The Years of Bloom: James Joyce in Trieste, 1904-1920 (Wisconsin: Wisconsin Press, 2000$), 171$.

${ }^{78}$ Katia Pizzi, "City of Paper, City of Light," in Bele Antiche Storie: Writing, Borders, and the Instability of Identity Trieste, 1719-2007, ed. Charles Klopp (New York: Bordighera Press, 2009), 53.

${ }^{79}$ Centro Italo-Romeno di Studi Storici, La Stampa italiana e la "polveriera" d'Europa" (1905-1919) (Verona: Edizione, Unicopli, 1988), 13.

${ }^{80}$ Elio Apih, Trieste (Bari: Laterza, 1988), 88.

${ }^{81}$ Hametz (2005), 15.
} 
These views were best exemplified by the political movement "Democrazia Sociale Irredenta" (Unredeemed Social Democracy) which attributed a specific meaning to the upcoming war for national liberation. ${ }^{82}$ In a traditionally Mazzinian outlook, this political group conceived the natural borders of the nation in Carso and Brennero and, in contrast to the most radical nationalist groups, did not support the inclusion of Dalmatia within the national territory. These movements, both of which were heirs of Risorgimental nationalism, proved the existence of two conflicting faces of Adriatic irredentism: romantic and tolerant versus violent and authoritarian.

During the war, nationalist views dominated the ANTT and the irredentist associational network more generally. War was portrayed as an invaluable means for defense against future German or Teutonic aggression as well as the instrument to reassert the "Italianità" of the unredeemed lands which naturally stretched from Trento to Dalmatia. ${ }^{83}$ To attain these goals the internal structure and organization of the association gradually became more centralized and efficient in its war-time propaganda. The Association strove to give a single voice to the panoply of irredentist organizations (i.e. Pro Fiume, Alto Adige, Pro Dalmazia, Latina Gens, etc.) and to propagate the long-term goal of unconditional liberation from Austrian rule. The ANTT also called for the creation of a Committee of Internal Resistance in Trieste and specific national and local branches whose duty was to provide food and assistance to the local Italian population as well as soldiers and veterans once the conflict was over. ${ }^{84}$

Interestingly, the activity of the Association was not solely limited to the national territory in which it counted seventy different sections, but it also found support in branches located abroad. ${ }^{85}$ These branches of the ANTT profited from the favorable attitude of foreign allied governments and lobbied for support of the Italian struggle for self-determination in countries such as France and

\footnotetext{
${ }^{82}$ Fogar,34.

${ }^{83}$ FMSdt, Busta 1, fasc. 3 cc 65 (1917), 31.

${ }^{84}$ FMSdT, Busta 2, fasc 5 cc249 (April 7, 1918), 73.

${ }^{85}$ According to the records of the Presidency of the TT, the Association extended its network to South America, Central America, and Northern Europe, and its members were not simply Italians but also other nationals, for example the Belgian Emeline Ruelle. FMSdt, Busta 3, fasc 8, pp. 185-202.
} 
Great Britain. ${ }^{86}$ The ANTT steadily pursued the idea of Italian annexation for Austrian territories by competing with German propaganda, emphasizing the political and territorial rights of the Italian minority in the Habsburg Empire, and raising financial support through private and governmental contributions. In particular, the Association strongly advocated the resolution of border disputes with the prospective Yugoslav neighbor and, confronting the uncertainties of diplomatic negotiations, threatened the use of mass demonstrations and popular agitation, claiming that "So far I have been quiet but if necessary I will bring them on the square." ${ }^{\prime 87}$ These threatening statements and strategies provide useful insight into the main views of the Association and its indisputable departure from the previously moderate views of nineteenth-century irredentists who had called for the peaceful coexistence of Slav and German minorities.

After the war, these hopes were swept away by the hubris of nationalist rhetoric and the rise of Italian Fascism which led to what scholars have called "Trieste's darkest hour." As scholar Maura Hametz clearly points out, in 1918, the presence of the warship Audace in the port of the city exemplified the symbolic passage of territorial sovereignty to Italy. In Italian public discourse, Trieste became the guardian of the eastern border as well as the ideal platform to spread the past vestige of Italian influence across the Adriatic. These claims were amplified by the ANTT which did not cease its activities with the conclusion of the war; rather, during the peace talks it sought to exert pressure on Prime Minister Orlando in order to achieve the restitution of territories necessary to "reaffirm the entire Italianità of the Adriatic." 88 After recalling the past experience and successes of Italian irredentism, the central Committee of the Association outlined the new goal of post-war irredentism at its National Congress of June 1and 2, 1919: the conquest of Fiume, Spalato, Malta, Corsica, and Nice. These goals demonstrated the rising imperialist and colonial inclination of the movement's strategies, best exemplified in the slogan "we will not put away our sword as long as a

\footnotetext{
${ }^{86}$ FMSdT, Busta 1, fasc 5 cc252 (February 13, 1919), 109.

${ }^{87}$ FMSdT, Busta 2, fasc 5 cc249 (December, 1918), 31.

${ }^{88}$ FMSdT, Busta 1, fasc 5 cc252 ( April 3, 1919), 122.
} 
corner of Italy will be enslaved." ${ }^{89}$ Indeed, within the post-World War I irredentist narrative and despite its human costs, war was perceived as the best means to accomplish national unification and the wartime experience became one of the leading themes of nationalist propaganda.

In particular, the vacuum of power in the Julian region that accompanied the development of the Versailles Treaty left behind a legacy of social disorder, poor administrative organization, and political instability. Italian claims at Versailles, especially in regard to the Dalmatian region, clashed with renewed French interest in the Balkans and the territory was also divided along ambiguous Wilsonian lines of national self-determination. ${ }^{90}$ Ian Grainger has shown the inefficiency of such a criterion by stressing that, despite Italian claims of ethnic and territorial homogenization, the number of Slovene-speaking Slavs within the new postwar Italian borders was substantial. ${ }^{91}$ Moreover, Yugoslav committees for Slav self-determination proved the presence of a Slovene and Croatian ethnic majority inside the population living in Istria. ${ }^{92}$ Even though the expectations of the 1915 London Pact were not fully satisfied, Italy made substantial territorial gains: Trento, Trieste, South Tyrol.

During the post-war period, the presence of Italian troops in Trieste, the rising feeling of insecurity among the Slovenian minority, and the tension between reformist and radical fringes of the Italian Socialist Party favored the emergence of the local "Fascio." Due to its location on the border, Trieste became one of the most fascist cities with about $18 \%$ of the party's national members. The majority of the party's members in Trieste consisted of Worl War One veterans and irredentists who were easily attracted by both fascist propaganda and idealized continuities between the rhetoric of nineteenth-century patriotism and twentieth-century nationalism. In particular, the

\footnotetext{
${ }^{89}$ FMSdT, Busta 3, fasc 8, 208.

${ }^{90}$ Cattaruzza (2007), 123.

${ }^{91}$ Ian Grainger, "Trieste and the Foibe: Nation and Memory," Bullettin of the Society for Italian Studies (37) (2004): 7.

${ }^{92}$ John Ashbrook, "Politicization of Identity in a European Borderland: Istria, Croatia, and Authenticity, 1990-2003"

Nationalities Papers 39 (6) (November, 2011): 877.
} 
nationalist discourse emphasized the superiority of the Latin over the Slav civilization and metaphorically portrayed Italy as a mother who was unconditionally tied to her daughter, Trieste. ${ }^{93}$

After the war, the Triestine bourgeoisie, confronting the rising requests of the workers' movement, gradually shifted toward an alliance with the Fascist Party. The unwillingness of the socialist and communist forces to ally with the conservative coalition resulted in their electoral defeat and ultimately facilitated the rise of the local Fascist Party. In order to further weaken the leftist and democratic parties, the Fascist Party exploited the question of Fiume, ethnic tensions, pre-war irredentist rhetoric, the connivance of the military government, and political violence. ${ }^{94}$

The new territorial configuration of the Eastern border was definitively established with the Rapallo Treaty, which was ratified on February 2, $1921 .{ }^{95}$ The treaty established the border at Monte Nevoso following the main lines drawn in the London Pact, yet left out Fiume which became a free city. ${ }^{96}$ In this regard, as Massimo de Leonardis argues, the Rapallo Treaty moved the Italian eastern border further east and made greater territorial concessions to Italy as compared to the London agreements and the Wilsonian line. ${ }^{97}$ As this case clearly demonstrates, the principle of nationality became a powerful means to promote an expansionist foreign policy, cloaked in previous irredentist arguments about the "Italianità" of these disputed lands.

In a multi-ethnic context like Trieste, these issues were used to legitimize the regime's policies, mobilize national and local public opinion, and shape national identity in opposition to the “other" border neighbor. Between 1919 and 1921, the eruption of workers' struggles throughout the country, also known as "the Red Two Years," further alienated moderate support for parliamentary liberalism, favored phenomena of political violence, and, especially in Trieste, anti-Slav feelings. Thus, the city became the ideal platform for the fascist expansionist campaign in the Adriatic as

\footnotetext{
${ }^{93}$ Katia Pizzi, A City in Search of an Author (London: Sheffield Academy Press, 2001), 58.

${ }^{94}$ Claudio Silvestri, Dalla redenzione al fascismo. Trieste 1918-1922 (Udine: Del Bianco, 1959), 52.

${ }^{95}$ See Map II.

${ }^{96}$ Cattaruzza (2007), 162.

${ }^{97}$ Massimo de Leonardis, "Il Confine orientale dell'Italia," Storia Urbana 117 (2007): 74.
} 
Map II: Italy's Eastern Border after the 1921 Rapallo Treaty

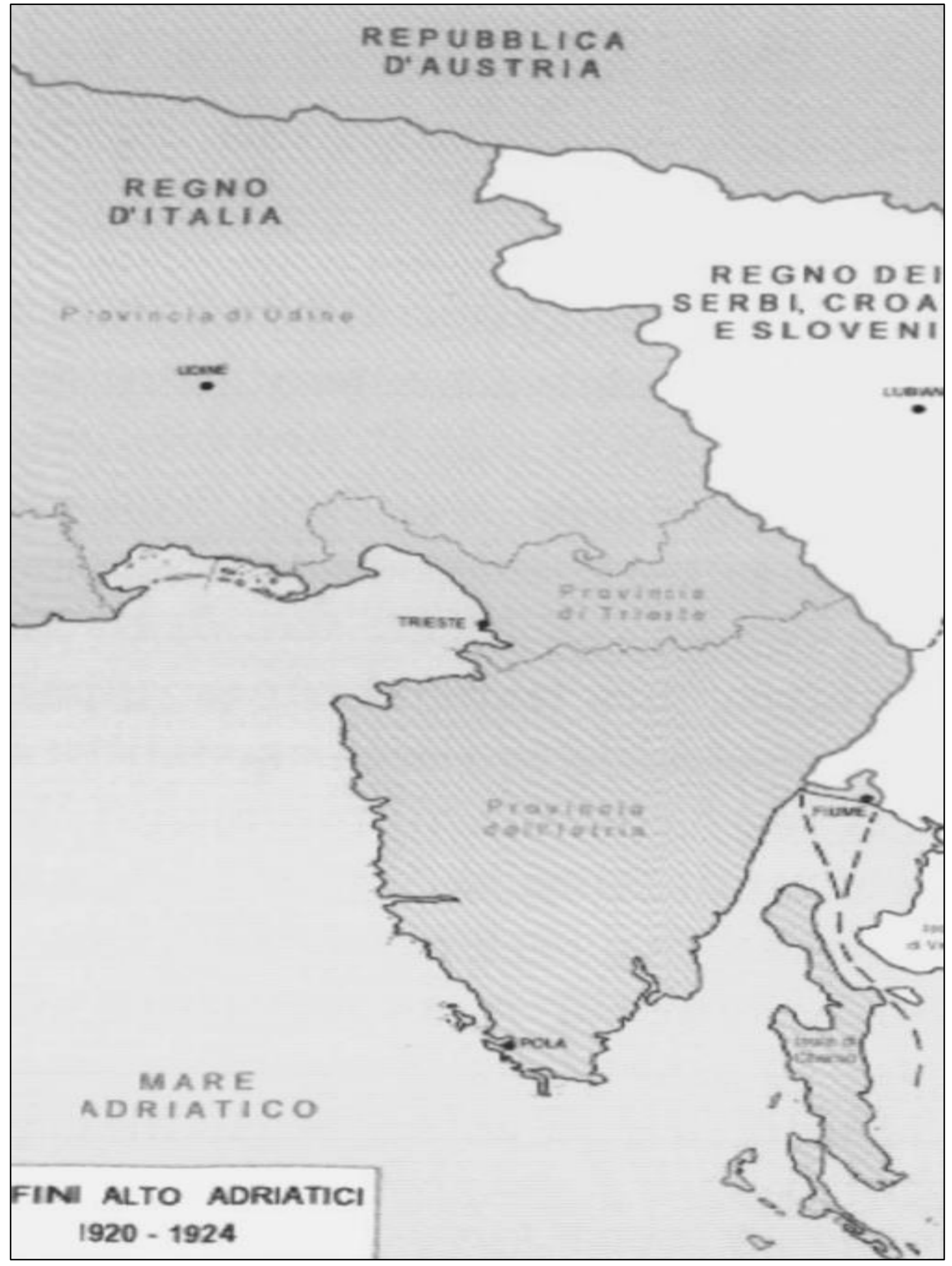


best exemplified by Mussolini's words, “When ethnicity does not agree with geography...it is ethnicity that must move." $" 98$

World War One also abruptly ended the special long-term relationship between Trieste and the Danubian-Habsburg hinterland. This traditional source of Trieste's prosperity never fully recovered from the wounds of the war and its aftermath. Despite the rhetoric that surrounded the acquisition of the Julian city, the national government failed to comprehend the detrimental effects of the Great War on the local economy. Consequently, trade of coffee, wood, and lumber strongly declined. Due to the lack of infrastructure and marginalization of the port within international trade, foreign firms withdrew investments from the local economy. The disruption of trade and the resulting endemic economic crisis contributed to the erosion of the cosmopolitan sources of Triestine identity. Fractions of the Triestine commercial bourgeoisie, however, still partially anchored to municipal traditions and hoping to protect its economic interests, showed "ambivalent loyalties" toward Mussolini's regime. ${ }^{99}$

In his work on Trieste between 1918 and 1922, Claudio Silvestri analyzes the transition from prewar irredentism to fascism and underscores the complex context in which the Triestine Socialist Party became the heir of nineteenth-century irredentism and actively supported the defense of minority rights and the political inclusion of minorities within the postwar Italian state. It became not just the strongest party of Trieste, but also the main promoter of political and administrative autonomy for the Julian city. ${ }^{100}$ The Socialists placed themselves between Mazzini and Tommaseo. While the former had envisioned the creation of a rationalized, centralist, and homogenized Italian nation by means of insurrection, the latter had proposed a gradual geo-political reformation that would ultimately establish a multi-national federation inside the Adriatic region. ${ }^{101}$ Socialist

\footnotetext{
${ }^{98}$ Arrigo Petacco, A Tragedy Revealed: the Story of the Italian Population of Istria, Dalmatia, and Venezia Giulia, 1943-1956 (Toronto: University Press, 2005), 14.

${ }^{99}$ Hametz (2005), 5.

${ }^{100}$ Silvestri, 9 .

${ }^{101}$ Reill (2012), 57.
} 
irredentists, while advocating Trieste's territorial incorporation inside the Italian state borders, also vouched for a political configuration that responded to its multi-cultural and heterogeneous reality.

In Trieste, especially, these ideas were largely shared by members of the combatants' movement who politically referred to the Republican Irredentist Front. In a study which strongly relied on the associational and national press as well as state documents, Giovanni Sabbatucci showed that the "Associazione Nazionale Combattenti” (National War Veteran Association, ANC), whose core was made of veterans from World War One, issued a programmatic manifesto declaring the pacifist, internationalist, and democratic orientations of this movement on November $4,1918 .^{102}$ In addition, the manifesto stressed the cult of homeland, the glorification of World War One martyrs, the independence from any political party, and the members' duty to follow a precise ethical and behavioral code. The movement also strongly criticized the Italian Liberal Party and condemned Italian adventurism in Fiume.

Luigi Gasparotto, one of the most representative figures of the ANC, expressed the movement's opposition to D'Annnunzio's adventurism and appealed to peace and political normalization of relations with the Yugoslav Kingdom. ${ }^{103}$ The ANC, however, failed to present itself as a viable alternative to competing liberal, fascist, and socialist political parties. ${ }^{104}$ Sabbatucci argues that the ranks of the movement showed considerable diffidence toward the Fascist Party until 1923; thereafter, political collaboration between the Fascist Party and the ANC significantly increased. ${ }^{105}$ Although an analysis of Gasparotto's papers partially contradicts Sabbatucci's findings and stresses that members of the ANC significantly supported fascism from 1919, it is hardly disputable that fascist rhetoric increasingly dominated the post-war nationalist network. ${ }^{106}$

\footnotetext{
${ }^{102}$ Giovanni Sabbatucci, I combattenti nel primo dopoguerra (Roma: Laterza, 1974), 71.

${ }^{103}$ Son of a Lombard patriot and ex-combatant in World War One, was appointed as head of the Associazione Nazionale Combattenti (ANC) and, after withdrawing to private life in 1924, went into exile in Switzerland. It was only in 1943 that he first joined the anti-fascist resistance and later the Southern Italian government during the last years of the Second World War. Fondazione Istituto per la Storia dell'Età Contemporanea (ISEC), Busta 1, Fasc.1, Documentazione Biografica.

${ }^{104}$ Sabbatucci, 223.

${ }^{105}$ Sabbatucci, 370 .

${ }^{106}$ Busta 1, Corrispondenza di L. Gasparotto Commissario Nazionale dell' ANC, Statuto dell'Anc, 26/12/1943 12/11/1951, fasc.14, s.fasc.1.
} 
Despite this, a study based on a set of letters, pamphlets, oral memories, and press associated with the figure of irredentist Gabriele Foschiatti highlights continuation of a democratic strain of "Italianità" within fringes of the Triestine post-war combatant movement which remained loyal to Republican irredentism. Although its prestige was locally undermined by the alliance between the local bourgeoisie and the rising Fascist Party, some Republican irredentists firmly condemned Fascism for its exploitation of national patriotism and broad use of violence. ${ }^{107}$

The competing views of various expressions of the post-war nationalist movement were outlined by the inter-war intellectual, Roberto Mirabelli. What emerges from Mirabelli's work is that irredentist propaganda diverged from the broader nationalist intellectual mainstream. In "Dalla Libia a Vittorio Veneto et ultra" (From Libya to Vittorio Veneto and Beyond), written in 1932, Mirabelli examined the main features of irredentism and emphasized the close connection between Italian rights in the Mediterranean and the Roman past. Mirabelli interpreted the Italian invasion of Libya as an "unavoidable duty" which pre-dated the conquest of Trieste. ${ }^{108}$ Indeed, expansion in the Mediterranean was portrayed as one of the imperative steps to complete the process of national unification and was used to depict irredentism as an internal force to break the external constraints imposed by the Triple Alliance.

Even though Mirabelli's arguments were full of nationalist rhetoric, he also called for the creation of a Republic to lead the new nation. Mirabelli not only criticized the fascist governmental structure but also implicitly criticized the regime's attitude and claims toward the Adriatic. Mirabelli argued that the "petty spirit of nationalism" mistakenly replaced national ambitions for redemption that, while legitimate on the Western border, still needed to be clarified with regards to the Dalmatia and more generally the eastern border. ${ }^{109}$ In disputing the extension of Italy's eastern border to the Dalmatian region, Mirabelli's arguments connected to nineteenth-century irredentism. Moreover, Mirabelli identified irredentism as a political phenomenon that pursued linguistic and

\footnotetext{
${ }^{107}$ Fogar, 65.

${ }^{108}$ Roberto Mirabelli, Dalla Libia a Vittorio Veneto et ultra (Milano: Società Editrice Dante Alighieri, 1932 ), 55.

${ }^{109}$ Ibid., 575.
} 
Republican unity and, embodying the Mazzinian goals of international brotherhood, created a "nation of Italians" who worked toward the establishment of a European federation in response to the vague Wilsonian ideas of self-determination. ${ }^{110}$ Thus, Mirabelli's notions of "Italianità" became more closely associated with Mazzinian notions of national patriotism rather than aggressive and expansionist territorial nationalism. Anchored to the enigmatic view of a Europe of nations, these convictions remained the intellectual property of a small elite which was unable to challenge the new exclusively fascist reading of nationality in border areas.

In Trieste, however, fascist efforts to mobilize public opinion around new mythological readings of the past such as the exhibition of the "Giugno Triestino (Triestine June)," the wide use of equestrian competitions and the exhibition of the "Three Venices," did not enthuse the local Triestine population, proving local resistance to fascist intellectual homogenization. ${ }^{111}$ The credibility of the regime was further impaired by its generally unsuccessful economic measures. Indeed, fascist policies damaged Trieste's port economy and only benefited pro-fascist or opportunist segments of the Triestine bourgeoisie in the short-term. Not only did the regime do little to improve Trieste's trade and railways, but the city came out on the short end of the regime's uneven reallocation of national resources. Between 1922 and 1936 the fascist government invested only 110 million in Trieste while bequeathing 425 million to another port city, Genoa. ${ }^{112}$ In combination with the economic depression of the late 1920s that encompassed Trieste and its Danubian hinterland, the Triestine economy was ultimately relegated to a position of subordination to an overwhelming German economic influence in the 1930s.

On a social level, fascist policies pursued the forced assimilation of the non-Italian population which, later referred to as "Italianization," reflected "fascist officials' heavy-handed attempts to Italianize the population" and justify Italian acquisition of the newly acquired eastern

\footnotetext{
${ }^{110}$ Mirabelli, 613.

${ }^{111}$ Hametz (2005), 92.

${ }^{112}$ Ibid., 62.
} 
borderlands. ${ }^{113}$ This policy undermined perspectives of peaceful coexistence of the Italian and Slav communities and strengthened native Slav resistance in the region as exemplified by the activities of organizations such as TIGR or Borba. ${ }^{114}$ Maura Hametz's study on the fascist surname policy in the Adriatic region demonstrates that Mussolini's regime used a combination of violence (i.e. the fascist destruction of the Trieste National Hall hosting the local Slovene Theatre in1921) and judicial decrees to legally persecute and ban the use of Slavic "alien names." 115 Indeed, the enforcement of such a legal provision forced the Slav inhabitants of the Adriatic region to change their names in order to avoid discrimination. In her most recent work, Hametz proves that this fascist policy was met with local resistance. Luigia Paulovich, an elderly Triestine widow, claimed that it was her duty to preserve her last name to honor her husband and family. Thus, she filed against the Prefect of Trieste in 1931 and successfully challenged the legislative provision that previously imposed the "Italianization" of her surname. Paulovich's case shows that legal resistance to fascist control could succeed and public officials' adherence to liberal principles of rule of law made the erosion of former political liberties a slow and gradual process. ${ }^{116}$

Nonetheless, ideas of "Italianità," loaded with a new and imperialist meaning, guided fascist domestic and foreign policies. ${ }^{117}$ The fascist regime pursued a strategy of homogenization that, especially in Trieste, was contrary to the traditional logic of assimilation and integration. Fascism's centralized and repressive policies systematically attempted to reshape the ethnic configuration of the Adriatic border and, while advancing the private interests of the traditionally Italian commercial elite, only partially accomplished the Italianization of Trieste and its surrounding region. Instead, it definitively undermined the traditionally hegemonic position of the Italian commercial network in the entire region. ${ }^{118}$ With regard to this issue, Giorgio Tombesi, a local prominent political figure of

\footnotetext{
${ }^{113}$ Hametz (2012), 3.

${ }^{114}$ Ashbrook, 878.

${ }^{115}$ Hametz (2010), 416.

${ }^{116}$ Hametz (2012), 9.

${ }^{117}$ The literary elites of the city, among them personalities such as Svevo, Saba, and Gambini gradually moved from position of diffidence to positions of manifest anti-fascism and harshly criticized the regime's manipulaiton of Mazzinian ideas of "Italianità." See Bruno Maier, Gli scrittori triestini e il Fascismo (Trieste: Italo Svevo, 1975).

${ }^{118}$ Ara and Magris (2007), 115.
} 
the Triestine Christian Democratic Party, argued that the city, traditionally ruled by a maritime rather than landowning bourgeoisie, was never fully fascist and was merely highly influenced by fascism. ${ }^{119}$ As Hametz has discussed, Triestine officials' enforcement of the surname legislation revealed a "disjuncture between local understanding of nationalism and fascist vision of the Italian nation." ${ }^{120}$ Residents like Paulovich understood her own "Italianità" as a form of patriotism and loyalty to an Italy that happened to be under fascist rule. Meanwhile, local governmental representatives also "remained confused and uncertain as to the contours of acceptable or expected acculturation and nationalization of fascist policy." ${ }^{\prime 21}$ Thus, the enforcement of central directives was characterized by contradictions and inconsistencies that undermined fascist ambitions for ethno-cultural homogenization of the border.

In addition, the late arrival of the Triestine society in the new Italian state and the collaboration between the Italian and Slovenian Communist movements boosted further resistance to the official policies of "Italianization" of the city and its surroundings. The radical left, in particular, vigorously opposed the harshness of the fascist repression on the Adriatic border between 1921 and 1928. ${ }^{122}$ In 1924, after Fiume's annexation, the government continued its policies of centralization which aimed to abolish regional autonomies, impose the use of Italian language at all social levels, and integrate the local society of this multicultural area into the national community. ${ }^{123}$

Fascistization along the Adriatic border, Hametz argues, was clearly rooted in pre-war nationalist programs that attempted to downgrade yet assimilate the Slav population of the region. Fascist policies, indeed, were strongly informed by late nineteenth-century eugenic views which stressed the inferiority of Slavic civilization and its identification with the socialist enemy.

\footnotetext{
${ }^{119}$ Tombesi was born in Udine in 1926 and was member of the Triestine bourgeoisie. He was member of the Italian Catholic University Federation (FUCI) and received a university degree in engineering. First employed inside the local administration, Tombesi gradually emerged as a leading members of the new post-war Triestine Christian democrats after 1956.

${ }^{120}$ Hametz (2012), 20.

${ }^{121}$ Ibid., 203.

${ }^{122}$ Pierluigi Pallante, La tragedia delle "foibe" (Roma: Editori Riuniti, 2006), 26.

${ }^{123}$ Cattaruzza (2007), 183.
} 
Beginning with the year 1930, however, these policies sharply diverged from early fascist policies of assimilation through education and moved toward a more exclusionary racial and ethnic approach toward local non-Italians. ${ }^{124}$

The population of the province of Trieste, which included five political districts stretching from Monfalcone to Capodistria, already counted 348,494 people of whom only 9,400 were nonItalians in 1931. ${ }^{125}$ Among them, about one third or 2,836 were Yugoslavs, 2,500 of whom lived in the urban area of Trieste. In 1936, the population rose to 357,142 , with only 6,052 identified as "foreigners" and about 1,496 as Yugoslavs. ${ }^{126}$ As these statistics show, Slav minorities were gradually forced out of Trieste's urban areas. In spite of this, scholars such as Raoul Pupo have disproved fascist claims of success in the process of denationalization and de-slavization. ${ }^{127}$ Pupo has shown that Slav minorities survived in the rural areas and maintained their economic assets despite fascist policies of expropriation. In fact, the fascist repression resulted in strengthening rather than weakening the irredentist claims of the Slovenian population. Contrary to what was expected by the regime, Slovenian irredentism did not disappear and rather strongly reemerged as part of the Yugoslav Communist resistance during World War Two.

Until 1938, the fascist regime carried out a process of changing Slavic names, suppressed the Slovenian associational network, implemented the systematic confiscation of property, and used physical violence in the form of deportation and death sentences despite local resistance. All of the aforementioned policies tended to deny the existence of a minority problem and, instead, magnified the assimilatory capacity of the superior Italian civilization, best exemplified by the idea of "Italianità." 128 Such logic became further radicalized after 1938 and was targeted especially at the Slovenian clergy whose members were traditionally considered the vanguard of Slav nationalism.

\footnotetext{
${ }^{124}$ Hametz (2012),48.

${ }^{125}$ Istituto Centrale di Statistica del Regno d'Italia, VII Censimento generale della popolazione (21 aprile 1931-IX, Volume II, Fascicolo 33 Provincia di Trieste), xiv.

${ }^{126}$ Istituto Centrale di Statistica del Regno d'Italia, VIII Censimento generale della popolazione (21 aprile 1936-XIV, Volume II, Fascicolo 34 Provincia di Trieste), x.

${ }^{127}$ Raoul Pupo, Il lungo esodo. Istria: le persecuzioni, le foibe, l'esilio (Milano: Rizzoli, 2005), 41.

${ }^{128}$ Glenda Sluga, "Italian National Identity and Fascism: Aliens, Allogenes and Assimilation on Italy's North-Eastern Border,” ed. Bedani and Haddock, 163-190.
} 
In addition, the city's Jewish population, which was highly represented among local nationalists and members of the middle-class, fell victim to fascist racial policies. In 1945, only 400-500 Jews had survived out of the total population of about 5,000 who had inhabited the city before the war. Indeed, once the war began, Trieste became an epicenter of fascist anti-Semitism whose actions were facilitated by a security apparatus put in place between 1938 and 1941.

Even though most of the local population acted as bystanders of the regime's policies, republican and communist leaders organized the movement of local resistance. ${ }^{129}$ In 1941 , after the Axis invasion of Yugoslavia, Italy occupied Dalmatia, the so- called province of Ljubljana (central and southern Slovenia), and Montenegro. The disastrous Italian military campaign in Greece, however, not only ended Mussolini's plan of a "parallel war", but also made Fascist Italy politically and militarily dependent on its German ally. As a consequence of the Barbarossa Operation, violence decisively escalated in the region. The Italian army carried out harsh and repressive policies against the Yugoslav partisans and set up a vast network of camps that incarcerated between 30,000 to 70,000 people. Thousands of partisans and civilians were executed during the Italian occupation yet the commanders of the Army remained unpunished after the war, despite military investigations of war crimes. ${ }^{130}$ Military occupation was opposed by the Yugoslav resistance, contributing to a vortex of violence which, pervaded by mutual acts of retribution and revenge, accompanied the last two years of the war and witnessed the demolition of Italian statehood along the Adriatic border.

\section{Surviving the War: The Experience of National Resistance and the Dark Age of "Italianità"}

On July 25, 1943, the fall of Mussolini’s regime immediately exposed the downsides of twenty years of fascism and its detrimental effect on pre-war expressions of Italian patriotism which

\footnotetext{
${ }^{129}$ Hametz (2005), 30.

${ }^{130}$ See Michele Battini, The Missing Italian Nuremberg: Cultural Amnesia and Post-War Politics (New York: Palgrave MacMillan, 2007). For an assessment of Italian policies of occupation from a Yugoslav perspective, also see Sabrina Ramet, The Three Yugolsavias: State Building and Legitimation,1918-2005 (Washington: Woodrow Wilson Center Press, 2006).
} 
had been strongly connected to the myth of Risorgimento. ${ }^{131}$ In his edited volume on the history, memory, and representation of Fascism, Patrizia Dogliani has shown that during fascist rule, this myth found symbolic expression in the cult of the flag and the parallel militarization of society and its associative networks. Such a myth, however, proved weak amid the war-time economic and military crisis that crossed the Italian peninsula and fueled popular disillusion. ${ }^{132}$

On September 8, after signing the military government's armistice with the Allies, the Italian Army fell apart. ${ }^{133}$ The Italian peninsula was occupied in the North by the Germans and the neo-Fascist Republic of Salò and in the South by the Allies. ${ }^{134}$ Some military officers and civilians called for national resistance in northern Italy while others decided to remain passive bystanders. The Italian scholar Ernesto Galli Della Loggia would later refer to September 8, 1943 as the "death of the fatherland," associating the disintegration of the national army and the collapse of the nationstate with the disruption of the nationalist ideas that were born from the nineteenth-century experience of Risorgimento. ${ }^{135}$

Sentiments of national identity that were traditionally anchored to the legitimizing forces of the monarchy or the experience of fascism were indeed swept away by the war. In this context, the national resistance, under the leadership of the Committee for National Liberation located in Rome (CLN) and the Committee for National Liberation of Northern Italy located in Milan (CLNAI), slowly coordinated its activities with the Allied forces and the provisional government of General Pietro Badoglio. ${ }^{136}$ From the beginning, however, a variety of conflicting political and social

\footnotetext{
${ }^{131}$ For an analysis of the most recent and exhaustive interpretations of Italian "Risorgimento" that provides a broad and thoughtful examination of the main scholarship on this subject, see Lucy Riall, Risorgimento: The History of Italy from Napoleon to Nation State (New York: Palgrave MacMillan, 2009).

${ }^{132}$ Patrizia Dogliani, "Constructing Memory and Anti-Memory: the Monumental Representation of Fascism and its Denial in Republican Italy," in Italian Fascism: History, Memory, and Representation, ed. R.J.B. Bosworth and Patrizia Dogliani (New York: St. Martin Press, 1999), 14.

${ }^{133}$ Gustavo Corni, "Italy," in Resistance in Western Europe, ed. Bob Moore (New York: Berg, 2000), 159.

${ }^{134}$ For an overall view of the events of 1943 in Italy see Aga Rossi. Una nazione allo sbando. L'armistizio italiano del settembre 1943 e le sue conseguenze (Bologna: Il Mulino, 2003). See also Philip Morgan. The Fall of Mussolini: Italy, the Italians, and the Second World War (New York: Oxford University Press, 2007).

${ }^{135}$ Ernesto Galli Della Loggia, La morte della patria: la crisi dell'idea di nazione tra resistenza, antifascismo e Repubblica (Roma: Editori Laterza, 1996), 15.

${ }^{136}$ It is in this context that the last years of war became also the formative years of the myth of national resistance. The "new" nation, suspicious of militarism, authoritarianism, and "statism," all synonymous with the fascist "ventennio," turned to the heroism and moral value of national resistance. This myth, centered on the experience of tiny minority
} 
orientations fragmented the movement of national resistance, ultimately weakening popular

sentiments of national identity. ${ }^{137}$

The resistance movement was highly divided especially in borderland cities such as Trieste and, therefore, experienced the internecine strife of the national civil war to a larger extent. ${ }^{138}$ In the words of local intellectual Carl Schiffrer, September 8 coincided with "the year zero of Italianità." ${ }^{139}$ From September 10, 1943 Trieste and its surrounding territory was occupied by the German Army which established the Operational Zone of the Adriatic Littoral. ${ }^{140}$ Thus, the northern Adriatic coast became a theatre of Nazi-fascist and Titoist violence that fueled the territorial aspirations of conflicting nationally and politically oriented movements. ${ }^{141}$ While violence from both partisans and collaborators became a daily occurrence for those living on the border, it also paralleled the social fragmentation and geo-political separation of Trieste from the rest of Italy and left an indelible mark in the memory of the Italian local population. ${ }^{142}$ Consequently, the dissolution of the Italian state and its institutions in the region promoted a deep sense of insecurity among the local Italian population and deprived it of any means of protection from Yugoslav waves of retribution. Therefore, whereas the Italian Armistice with the Allies became a day of national

\footnotetext{
that exemplified the idea of a nation in arms, provided a moral base for the new post-war Republic. On this subject, the Italian and English literature is very broad. For a good overview see, for example, Philip Cooke. The Italian Resistance: An Anthology (New York: St. Martin Press, 1997).

${ }^{137}$ This experience was a heterogeneous phenomenon whose narrative, articulated throughout five different historical phases in the post-war years, was shattered into "multiple" collective and individual memories that deeply diverged from each other. For example, see Philip Cooke. The Legacy of the Italian Resistance (New York: Palgrave MacMillan, 2011). In particular, the absence of a single and coherent account of the formative experience of the new Republic weakened not only its legitimacy but also common understanding of unifying notions of national identity. See Andrea Mammone, “A Daily Revision of the Past: Fascism, Anti-Fascism, and Memory in Contemporary Italy" Modern Italy 11 (2) (2006): 219.

${ }^{138}$ In one of the most compelling works on the subject, Claudio Pavone explained the nature of these last two years of war by adopting a classic tripartite categorization of civil war, war of liberation, and class war. He examined this war as a single violent experience that embodied hopes for peace and stability, the immense legacy left by the fascist regime, the dreams and illusions of Catholic, Socialist, and Communist resistant, and the uncertainty that pervaded the disbanded national Army. See Claudio Pavone. Una guerra civile: saggio storico sulla moralità nella resistenza (Torino: Bollati Boringhieri, 1991).

${ }^{139}$ Jozè Pirjevec, Foibe: una storia d'Italia (Turin: Einaudi, 2009), 38.

${ }^{140}$ See Map III.

${ }^{141}$ Pamela Ballinger, History in Exile (Princeton: University Press, 2003), 21.

${ }^{142}$ Giampaolo Valdevit, Trieste: storia di una periferia insicura (Milano: Bruno Mondadori, 2004), 38.
} 
Map III: the Operational Zone of the Adriatic Littoral

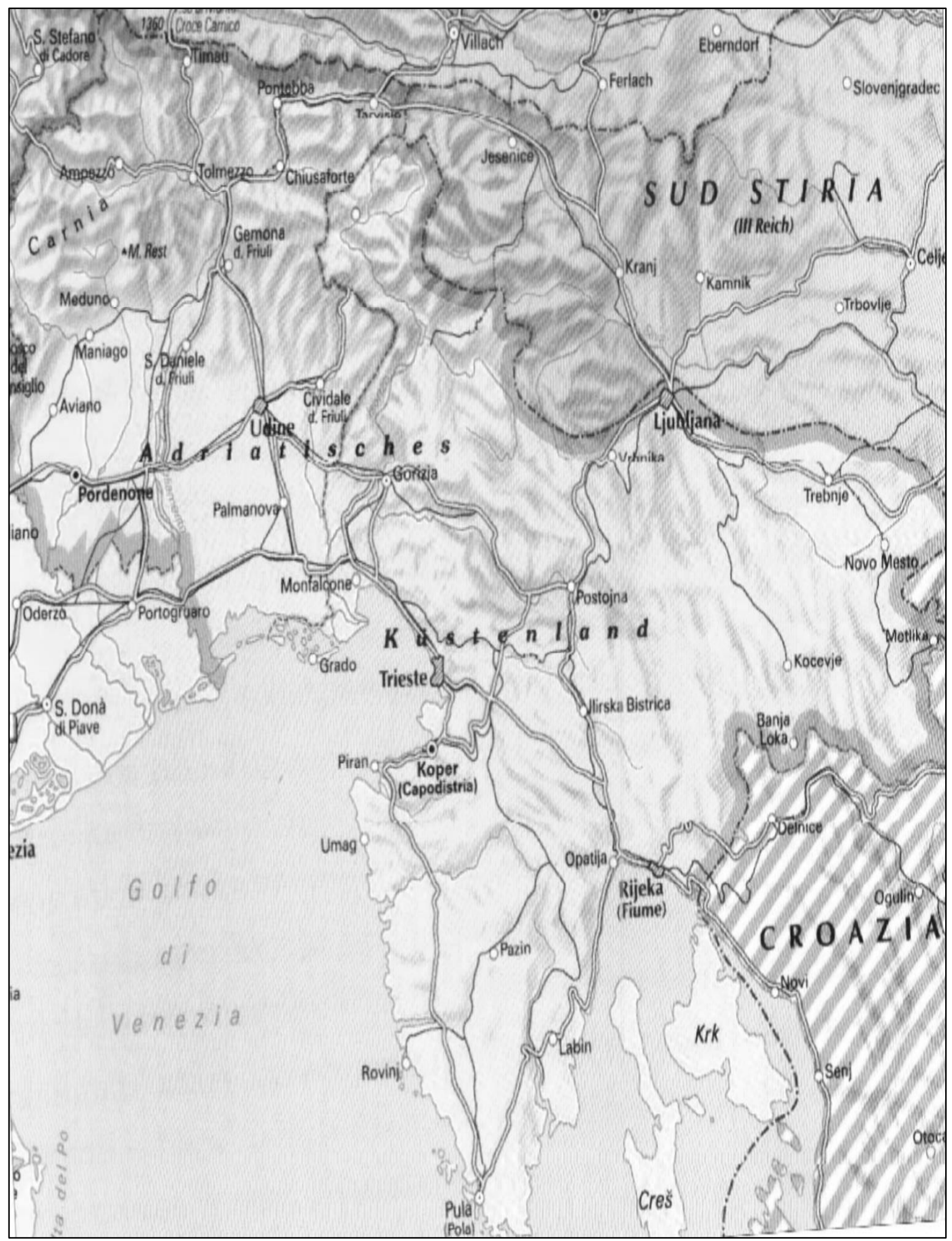


liberation in Slovenian popular memory, it represented defeat and mass murder in the memory of local Italians. ${ }^{143}$

From 1943, the armed communist led Yugoslav resistance (AVNOJ) responded to German occupation by declaring plans to annex the Istrian lands as part of the post-war territorial goals of the Yugoslav liberation movement. ${ }^{144}$ Only a small fraction of Italian soldiers, about 8,000 out of 40,000, joined Yugoslav communist resistance formations. Many of the remaining soldiers joined Italian partisan formations, were murdered or subjected to imprisonment in Titoist camps. ${ }^{145}$ Moreover, among the Italian local population were significant segments that felt trapped between German hostility for Italian betrayal and mass violent retribution by Yugoslav partisans. ${ }^{146}$

During the fall of 1943 and the spring of 1945 , about 4,000 to 10,000 people were murdered in caves in the Istrian region, also known as "Foibe Istriane" (Istrian Karsic Pits). ${ }^{147}$ These victims, who were mostly yet not exclusively Italian, became the main symbol of both the demise of Italian statehood on the eastern border and the aggressive Slav nationalism. ${ }^{148}$ Although scholars generally agree that the victims were members of the regional fascist hierarchy, collaborationists, civilians, potential political adversaries and, in particular, middle-class Italians, they still debate if the actions were planned or spontaneous. ${ }^{149}$ Most importantly, whether the "foibe" were means to ensure “Tito's territorial goals and nation-building" $" 150$ or a dehumanizing "project of ethnic cleansing

\footnotetext{
${ }^{143}$ Luciano Monzali, "La questione jugoslava nella politica estera italiana dalla prima guerra mondiale ai trattati di Osimo (1914-1975)," in Europa adriatica: storia, relazioni, economia, ed. Franco Botta e Italo Garzia (Bari: Laterza, 2004), 37.

${ }^{144}$ Cattaruzza (2007), 261.

${ }^{145}$ Cinzia Maggio, La questione giuliano-dalmata nelle carte del Pci: i rapporti tra comunisti italiani, sloveni e croati e l'alba della guerra fredda (Roma: Societa' Dalmata di Storia Patria, 2010), 129.

${ }^{146}$ Paolo Emilio Taviani, Politica a memoria d'uomo (Bologna: Il Mulino, 2002), 198.

${ }^{147}$ Valdevit (1999), 61.

${ }^{148}$ Victims were most yet not all being Italian. Silvio Maranzana, Border Crossing: vecchi e nuovi intrighi attraverso Trieste (Trieste: Hammerle Editori, 2001), 35.

${ }^{149}$ Authors such as Luigi Pallante (2006) stressed the genocidal and spontaneous nature of Slav violence and the absence of any kind of structural plan. To contrast, works from scholars such as Raoul Pupo argue that the Yugoslav resistance carried out an elaborated plan to assure control of the territory and from the very beginning, the declarations of the Yugoslav resistance resembled the nationalist Slovenian idea of "ethnic territory." The arrangement of labor camps, the number of death sentences, the propaganda, and the systematic terror against the Italian minority underpin ideas of organized state violence intended to ease the process of denationalization, eliminate competing claims of national sovereignty, and favor Communist nation-state building in the region. See Raoul Pupo. Foibe (Milano: Mondadori, 2003).

${ }^{150}$ Giampaolo Valdevit, La crisi di Trieste: maggio-giugno 1945: una revisione storiografica (Trieste: Istituto Regionale per la Storia del Movimento di Liberazione nel Friuli Venezia Giulia, 1995), 19.
} 
carried out deliberately to eradicate Italians from Istria by killing them or forcing them to flee,"151 over time they epitomized the anxiety and uncertainty of Trieste's wartime experience which was perceived as a "traumatic cut of the umbilical cord and loss of motherland." 152 As I discuss in the next chapters, this argument of Trieste's violent physical separation from the rest of the nation was often echoed in the post-war years and within national public discourse to justify the return of the city and its territory to Italian sovereignty.

In this climate of violence and military defeat, early twentieth-century irredentist figures played significant roles both within the neo-Fascist Republic and the broader resistance movement. Collaborationists such as Cesare Pagnini and Bruno Coceani, previous members of the ItalianGerman association, used their irredentist past to legitimize the role of the Civic Guard, an auxiliary formation that, in service to the Nazi occupation authorities, was presented as the defender of "Italianità" in Trieste. This military body, which was supported by former irredentists and fascists, used both force and propaganda (i.e. La Voce di Gorizia) to oppose the Triestine Committee for National Liberation (CLN). Moreover, the Civic Guard based its legitimacy on the untenable idea of "legal resistance," and presented itself as the single element of continuity of Italian statehood. Its authority also rested on its claim to protect the local Italian population from the violent revenge of both German soldiers and partisans. ${ }^{153}$

By contrast, the CLN, which was created from the anti-fascist Triestine group of patriots “Giustizia e Libertà" (Justice and Freedom), embraced the ideals of national "Risorgimento" and portrayed resistance to Nazi-fascism as the fourth war of national independence. ${ }^{154}$ In particular, the CLN conceptualized "Italianità" according to nineteenth-century irredentist views which deeply diverged from the expansionist tones of aggressive twentieth-century fascism and "advocated a

\footnotetext{
${ }^{151}$ Petacco, 48.

${ }^{152}$ Pizzi (2001), 169.

${ }^{153}$ Fogar, 202.

${ }^{154}$ Roberto Spazzali, L'Italia chiamò: resistenza politica e militare italiana a Trieste 1943-1947 (Gorizia: Libreria Editrice Goriziana, 2003), 18.
} 
moderate pro-Italian stance that sought reconciliation with minorities in the Italian state. ${ }^{, 155}$ As historian Roberto Spazzali effectively argues, by adopting a conceptualization of "Risorgimento" shorn of nationalist motifs and slanted towards ideals of passion and liberty, the CLN situated itself between Communist and fascist forces by claiming September 8 as a day of national and European rebirth.

The Committee, which represented the core of Julian democratic resistance, challenged traditional views of Trieste as a center of political and national extremism and sought to remake it as a post-war laboratory of democratic and European patriotism. It advocated Italian and Slav cultural autonomy in political union with the Italian state, a regime based on liberty and equality and integrated into a European Federation. In its view, the new Italian state would ideally guarantee peaceful co-existence between both the Italian and Slav elements of the region, whose free port would promote economic prosperity.

These new "Europeanist" views were strongly influenced by ideas of Triestine cosmopolitanism and were used by local intellectuals to reshape traditional understandings of Italian identity in a more conciliatory nuance that echoed the former ideals of nineteenth-century irredentism. ${ }^{156}$ Indeed, in the pamphlet "Il Problema Nazionale della Venezia Giulia Orientamenti Repubblicani e del Partito d'Azione" (The Problem of the Julian Venetian Region Republican Orientation and Views of the Action Party) published in July 1943, Gabriele Foschiatti envisioned the union of all Italians living on the border as a preliminary step to the creation of a European Federation in which each nationality reasserted its cultural autonomy. The inclusive nature of democratic-patriotism, firmly anchored to "risorgimental" political traditions, contrasted with the aggressive and exclusionary nature of past national fascism. Intellectuals such as Gabriele Foschiatti and Carlo Schiffrer, both leading figures of the local patriotic movement, advocated the

\footnotetext{
${ }^{155}$ Hametz (2012), 140 .

${ }^{156}$ See Karlsen Patrick e Stelio Spadaro. L'altra questione di Trieste: voci italiane della cultura civile giuliana 19431955 (Gorizia: LEG, 2006).
} 
defense of Trieste's Italian identity according to principles of self-determination and ethno-political tolerance. $^{157}$

The Committee's propaganda replaced the fascist myth of Imperial Rome with Mazzini's ideals. The element of voluntary participation, especially among students and WWI veterans, was presented as the leading nexus between nineteenth-century patriots and the non-communist resistance movement of World War II. In addition, the movement proposed a new political solution for Trieste and Istria that was based on the idea of political autonomy within a new democratic Italy. The CLN rejected both monarchy and fascism, attacked the vicious collaborationism of the local commercial bourgeoisie, and criticized workers' conformity and inaction. ${ }^{158}$ This group of intellectuals and political leaders was inspired by nineteenth-century ideas of nation which were echoed in journals such as Il Ponte or Giustizia e Libertà (The Bridge or Justice and Freedom) and guided the activities of patriotic associations such as the "Associazione Mazziniana Italiana" (AMI, Italian Mazzinian Association). More importantly, the experience of the Triestine CLN and its opposition to both Nazi-fascism and communist resistance represented an invaluable attempt to revitalize the unifying ideals of the past experience of national "Risorgimento" and advocate for Italian statehood over Trieste and its Istrian region.

Indeed, in 1944, Trieste's future territorial status became the object of political negotiations whose possible outcome depended on military and strategic considerations. Stalin clearly expressed his desire for the territorial incorporation of the Julian city and its surrounding area to Yugoslavia; however, he made such a solution dependent on the acquiescence of the civilian population in the new Yugoslav Federation. ${ }^{159}$ Palmiro Togliatti, the leader of the Italian Communist Party (PCI), was aware of the potentially dangerous repercussions of the Yugoslav occupation of Trieste yet he still

\footnotetext{
${ }^{157}$ Anna Millo, "Gabriele Foschiatti e Carlo Schiffrer nella tradizione di pensiero del patriottismo democratico a Trieste,” ed. Nuovo and Spadaro, 191.

${ }^{158}$ Fogar, 223.

${ }^{159}$ Leonid Gibjanskij, “L’Unione Sovietica, la Jugoslavia e Trieste,” ed. Valdevit (1995), 39-78.
} 
yielded to Yugoslav requests. ${ }^{160}$ This decision was strongly affected by the problem of "dual loyalty" toward international communism and the Italian nation that pervaded the national PCI. ${ }^{161}$ Failure to resolve this dilemma decisively affected its political actions toward the eastern border and, in an unclear response to Tito's annexationist ambitions, produced a "disturbed relationship" between the Italian and Yugoslav communist parties. ${ }^{162}$ At the same time, due the party's international and ideological interests, the defense of Italian sovereignty over the Triestine territory was downplayed within the actions and propaganda of the Communist resistance. ${ }^{163}$

Undaunted, Italian Communist partisan formations of the Julian Venetian Region complied with the directives of the Yugoslav resistance and acted with a single voice in the region until the summer of $1944 .{ }^{164}$ Slovene propaganda, massive retribution against Italians, incidents between Slovene and Italian partisan formations, and the inclusion of Triestine Communist formations (Garibaldi Brigades) within the XI Slovene Corp, alarmed the local population and heightened the concerns of the Italian national resistance movement for Tito's annexationist goals. ${ }^{165}$ Ultimately, the PCI, which recognized Slovene rights for self-determination, had to face the dilemma of supporting either Yugoslav assertions or the CLN's defense of Italian territorial rights in the region. In October 1944, Togliatti aligned with Stalinist and Yugoslav foreign policy and implicitly recognized Yugoslav claims to the Julian city by inviting the local Triestine population to support Tito's Army in the final struggle against the Nazi-Fascist regime of occupation. ${ }^{166}$ Within this

\footnotetext{
${ }^{160}$ Elena Aga Rossi and Victor Zaslavsky in Togliatti e Stalin: il PCI e la politica estera staliniana negli archivi di Mosca (Milano: Il Mulino, 2007) show the irreconcilable tension between the PCI's ideological affiliation to Moscow and its geographical location within the Western bloc. Rossi and Zaslavsky make a clear argument about Togliatti's moderate Stalinism and preference to advance class over national interest which resulted in the politicization rather than democratization of post-war Italy.

${ }^{161}$ Roberto Gualtieri, Il PCI nell'Italia Repubblicana1943-1991 (Roma: Carocci, 2005), 48.

${ }^{162}$ Maggio's emphasizes that the wartime unity of the Italian and Yugoslav communist forces that opposed the fascist occupation in the Adriatic region was broken after 1943 when, especially in Istria, the tension between selfdetermination and annexation resulted in political discrimination and organized violence against the Italian segments of the local population. After the 1944 "Salerno turn", Togliatti was forced by Moscow to minimize PCI support for Italian national interests on the Eastern border, support the wartime needs of the Yugoslav resistance and, despite his partial opposition, show acquiescence to Tito's territorial goals.

${ }^{163}$ See Peter Karlsen. Frontiera rossa: Il PCI, il confine orientale, e il contesto internazionale 1941-1955 (Gorizia: Libreria Editrice Goriziana, 2010).

${ }^{164}$ Pallante, 70.

${ }^{165}$ Maggio, 234.

${ }^{166}$ Cattaruzza (2007), 273.
} 
context, the PCI and its partisan formations left the Julian Committee of National Liberation whose leadership thereafter was entrusted to the "Partito d'Azione" (Action Party) along with the socialist, liberal, and Christian Democratic parties. ${ }^{167}$ This situation, which was undoubtedly complicated by the conflicting American and British strategic orientations toward the region, deepened the tensions among non-Communist Italian and Yugoslav partisan formations. ${ }^{168}$ Thus, between February and May, in his correspondence with Moscow, Togliatti asked for Soviet intervention to find a suitable accommodation with Tito and proposed the internationalization of Trieste. Despite this, he also recognized the legitimacy of specific Yugoslav rights over the pre-war Italian eastern border. ${ }^{169}$

In this context, Allied and Titoist forces competed in what became known as "The race for Trieste," a phase marked by mass violence and intense bombing that affected the entire population living in the region. The Italian-Slovenian Liberation Front successfully orchestrated a popular uprising on April 28, which anticipated the arrival of the Titoist formations. ${ }^{170}$ In commenting on the insurrection, which was preceded by negotiations between the local Italian bishop and the German forces, Spazzali has stressed that pro-Communist propaganda portrayed the actions of the CLN as "covert fascism." ${ }^{171}$ Instead, a sophisticated urban network, the efficient coordination of small clandestine cells inside the city, and the significant participation of previous military Italian formations and railways employees underscored the successful actions of the CLN, which, Spazzali argues, played a greater role than Tito's partisans in freeing Trieste. ${ }^{172}$

On May 1, 1945, Yugoslav forces entered the city and disarmed the indigenous Italian resistance movement whose united front was broken when workers aligned with Tito's partisan

\footnotetext{
${ }^{167}$ Rossi and Zaslavski, 141.

${ }^{168}$ In February 1945, under the command of the Slovenian IX Corps, a communist-oriented Italian partisan formation named after Garibaldi carried out the massacre of the Italian non-communist Osoppo Brigade. The attack was due to the Brigade's suspected bargaining for a military alliance with the fascist unit X Mas and its unwillingness to submit to the directives of the IX Corps. Petacco, 76.

${ }^{169}$ Rossi and Zaslavski, 144.

${ }^{170}$ The success of this uprising rested on an associational network that could count on about 2,000 members, a developed clandestine press, and about 14 brigades at the moment of the insurrection See Milan Pahor, "Sloveni e italiani insieme nella liberazione della città di Trieste. L'azione del comando citta' di Trieste e di unità operaia," Qualestoria 31(1) (2006): 77-78.

${ }^{171}$ Roberto Spazzali, Volontari della libertà: dalla resistenza politica all'insurrezione armata: documenti e testimonianze (Udine: Del Bianco Editore, 2008), 12.

${ }^{172}$ Spazzali (2003), 114.
} 
formations. ${ }^{173}$ The division between local pro-Italian and Communist resistance movements highlighted the complex distinction between patriots and resisters; the former was committed to defending the Italian identity of the city while the latter was devoted to defeating Nazi-fascism and relied both politically and militarily on the Yugoslav movement of resistance to do so. ${ }^{174}$ As a result, the CLN became a target of Yugoslav repression, persecution, and accusations of collaborationism. Fearing Yugoslav retribution, the German commander in the region finally surrendered to New Zealand forces on May 2.

For 40 days Trieste was held by the Yugoslav forces, resulting in a second wave of repression, deportation and murder of Italian fascists, collaborationists, and civilians as well as the abolition of any surviving Italian institutions. ${ }^{175}$ Tito's claims of "building socialism” became untenable amid the widespread violence in Trieste and forced de-Italianization of the Adriatic region which strengthened local feelings of anti-Communism. ${ }^{176}$ Even though Togliatti declared the indisputable "Italianità of Trieste" on May 7, the experience of Yugoslav occupation left a longlasting scar on the memories of the Italian population. ${ }^{177}$

It is noteworthy that the experience of the non-Communist resistance on the border and the actions of the Triestine CLN were both motivated by fear and antagonism toward Yugoslav retribution as well as the determination to reassert Italian territorial sovereignty of the Julian Venetian region. ${ }^{178}$ The idea of continuity with pre-fascist democratic traditions which, as highlighted previously, were instilled within the experience of nineteenth century Adriatic

\footnotetext{
${ }^{173}$ Rossi and Zaslavski, 289.

${ }^{174}$ Spazzali (2003), 76.

${ }^{175}$ The atrocities of those days, mainly aimed at Italians, are best symbolized by the unbearable detention and life conditions of the Goli Otok camp where about 30,000 to 50,000 prisoners transited over time. Especially after 1948, Stalinist domestic opposition to Tito became the main target of governmental repression and the camps quickly filled with regime's opponents also labeled as the "people's enemy." For an account of political violence in Tito's Yugoslavia see La Jugoslavia sotto il terrore di Tito (Roma: Edizioni di Cultura Sociale, 1949).

${ }^{176}$ Pallante, 121.

${ }^{177}$ Such a statement only partially succeeds to rehabilitate Togliatti's strategy toward the Eastern border. After the end of Yugoslav occupation on August 1945, Togliatti's plans prospected administrative autonomy for Trieste for a period of two or three years, later followed by a popular plebiscite. Such plans clashed with Yugoslav-Soviet proposals of total control on the region and in November 1945 the Italian communist party and the communist party of the Julian region separated. After Stalin's agreement on the internationalization of Trieste and its hinterland, Togliatti's again attempted to find a compromise with Tito. Togliatti proposed an exchange between Trieste and Gorizia that, labeled as unacceptable by Italian socialists, was also rejected by both local and national public opinion.

${ }^{178}$ Spazzali (2008), 103.
} 
irredentism, made the CLN "a small laboratory of democracy and antechamber to liberty.",179 Despite its invaluable efforts, the Triestine CLN occupied a marginal place within the post-war nationwide public discourse and was overshadowed by the uniform portrayal of the experience of national resistance.

The new Republic, indeed, depicting Fascism as a parenthesis in Italian history, highlighted the idea of national resistance as the continuation of the experience of Italian Risorgimento; ${ }^{180}$ however, the problematic reconciliation between its monolithic depiction and reality adversely affected the value of national resistance as a multi-faceted shared and regenerative experience for the entire nation. After 1945, when dealing with the eastern border, political leaders repeatedly turned to the myth of World War One and the idea of a nation in arms whose courage and sacrifice legitimized Italian rule of Trieste and its territory. On these bases, politicians and public opinion of center-right orientation relentlessly advocated Italian sovereignty of the eastern border in post-war years.

\section{A Complex and Violent Transition: from a Habsburg to an Italian City}

This chapter has underlined the existence of varied and unpredictable manifestations of Italian Risorgimento, among them Adriatic irredentism, that were partially eroded and supplanted by aggressive twentieth-century Italian nationalism. Mark Mazower has recently suggested that national irredentism embodied the nationalism of the nineteenth-century pan-Germans whose "goal had been to win the largest possible state, which left as few countrymen as possible outside its borders. $" 181$ This view has also been generally associated with nineteenth-century Italian irredentism and its goal of territorial expansion.

In contrast to this standard view of irredentism, I have emphasized that Adriatic irredentism within the Habsburg Imperial framework was not simply violent, radical, or separatist

\footnotetext{
${ }^{179}$ Spazzali (2008), 348.

${ }^{180}$ Fabio Fernando Rizi, Benedetto Croce and Italian Fascism (Toronto: University Press, 2003), 246.

${ }^{181}$ Mark Mazower, Hitler's Empire: How the Nazis Ruled Europe (New York: Penguin Press, 2008), 5.
} 
in its essence. Adriatic multi-national irredentists mainly promoted a national model of "consociationalism" which rested on the idea of cultural autonomy within a multinational state, namely the Habsburg Empire. ${ }^{182}$ In Trieste, especially, the Italian commercial bourgeoisie initially embraced these irredentist views which best served its economic interests and cosmopolitan orientation. $^{183}$

Due to the prominence of economic over political considerations, the Triestine bourgeoisie endowed "Italianità" with a cultural rather than territorial essence which found its best representation within an imaginary and constructed cultural community. Within this community both the commercial bourgeoisie and Italian-speakers in Trieste gradually identified themselves as Italian. This elite-led movement forged a specific ideal of Italian identity that enabled the coexistence of national groups who reinterpreted their own national myth in differing ways without necessarily resulting in violent conflict between them. At the same time, Adriatic multi-national irredentists also emphasized the strength of regional cultures, municipal traditions as well as dynastic loyalty during a period usually seen as the golden age of nationalism.

In particular, until the late nineteenth-century, manifestations of autonomous cultural and linguistic ambitions, which became an ever-present theme within the public sphere for the Italianspeaking population, supported ideas of "Italianità" and underscored Adriatic irredentism and its network of associations. During this period, Trieste's active patriotism was more an elite rather than mass phenomenon that strongly relied on a European conceptualization of self-determination as the indisputable right of historic nations. ${ }^{184}$ Afterwards, however, multiple interpretations of "the nation" grew and competed with each other, fostering mutual ethnic and cultural antagonisms both in Trieste and its hinterland. Such conflictual relations undermined the traditionally peaceful coexistence between Italian and Slav communities, whose presence respectively dominated the region's urban and rural areas. In Trieste in particular, the Triestine bourgeoisie increasingly used

\footnotetext{
${ }^{182}$ See Ephraim Nimni. "Nationalism, Ethnicity, and Self-Determination: A Paradigm Shift?" Studies in Ethnicity and Nationalism 9 (2) (2009): 319-332.

${ }^{183}$ Jan Morris, Trieste and the Meaning of Nowhere (New York: Simon \& Schuster, 2001), 173.

${ }^{184}$ Ara and Kolb (1995), 60.
} 
the politics of national "redemption" as an instrument to protect their economic interests and oppose the emancipation of Slovene or Croatian peasants and traders. ${ }^{185}$

Thus, Adriatic irredentism was gradually transformed and came to provide an increasingly ethnic and exclusive meaning to the idea of Trieste's Italian identity or "Italianità." ${ }^{186}$ While evolving into a clear and recognizable political actor with secessionist ambitions, the elite irredentist movement that had initially sought recognition for a specific Italian cultural identity merged with the nationalist mainstream of the twentieth century. Trieste's socio-economic degradation and liberal cultural assumptions that highlighted the dangerously backward nature of Slav civilization strongly emerged and fed the "clash of civilization" mentality among competing nationalisms. In a context of mutually exclusive economic competition and governmental discrimination, the Triestine irredentists radicalized their views. Although their claims found increasing support among significant segments of the local population, the cosmopolitan and municipal orientations of Trieste never entirely disappeared.

On the eve of the Great War, irredentist thinkers promoted the radical transformation of "Italianità" from a cultural and linguistic into an ethno-territorial concept. Notably, the reincorporation of Trieste inside the national borders after the war became the hallmark of nationalist propaganda. Furthermore, as argued by Glenda Sluga, Trieste came to exemplify the complexity and drawbacks of the conceptualization of national sovereignty along ethnic lines that had originally emerged from the Versailles Settlement. ${ }^{187}$ World War One indeed provided the spark that inflamed mutually exclusive claims of state territorial sovereignty in this traditionally mixed ethnic area. After 1918, the surviving ideas of nineteenth-century irredentism were adopted by the socialist movement and strongly opposed by radical nationalists. These ideas were further

\footnotetext{
${ }^{185}$ Vanni D’Alessio, “Identità collettive, stato e territorio. Sulle origini del nazionalismo in Istria” ed. Cocco and Minardi, 179-182.

${ }^{186}$ See Virginio Gayda, Modern Austria, Her Racial and Social Problems (London: T.F. Unwin, 1915).

${ }^{187}$ Glenda Sluga, The Problem of Trieste and the Italo-Yugoslav Border: Difference, Identity, and Sovereignty in Twentieth Century Europe (New York: State University Press, 2001), 6.
} 
weakened by the nationalist propaganda of the "mutilated victory" and, unable to compete with the attractiveness of fascist "Romanità," were relegated outside the new national narrative. ${ }^{188}$

Twenty years of Fascism and the process of "fascistization" further promoted the transformation and radicalization of "Italianità" as the Mussolini regime's overwhelmingly imperialist and expansionist ambitions turned toward the Mediterranean. ${ }^{189}$ During the fascist era, ideas of "Romanità" were further reinforced by the historical experience of Venice and its correlated notions of "Venezianità" in the Adriatic. It seems that both categories mutually reinforced each other and underscored colonial and imperialist conceptualizations of "Italianità." As Elsa Damien has recently pointed out, "Venice became associated with the idea of a strong, dynamic and colonial state, eventually embodying national-fascist ideals of "Italianità" and its imperial model was even more Italian than the one proposed by Rome." 190

While both "Venezianità" and "Romanità" became fruitful means to legitimize national territorial expansion during the inter-war years, surviving notions of local identity or "Triestinità" strongly contrasted with the goals of fascist political centralization. "Triestinità," indeed, forged a specific sense of belonging which, rooted within the intellectual legacy of Adriatic multinationalism, was based upon past traditions of administrative self-autonomy. ${ }^{191}$ Historically, Trieste's identity was effectively informed by four competing myths which were based upon its Hapsburg, irredentist, multicultural, and municipal past. The city's cultural diversity made Trieste a political and territorial crucible of geo-political changes that could hardly be reconciled with fascist policy to assimilate and homogenize its local population. ${ }^{192}$

\footnotetext{
${ }^{188}$ See Joshua Arthurs, Excavating Modernity: the Roman Past in Fascist Italy (Cornell: University Press, 2012).

${ }^{189}$ For a comprehensive analysis of Mussolini's foreign policy and fascist expansionist strategy in the Mediterranean see Robert Mallett, Mussolini and the Origins of the Second World War, 1933-1940 (New York: Palgrave MacMillan, 2003).

${ }^{190}$ Elsa Damien, "The Reversal of the Myths: Venetian Historiography and Adriatic Nationalism (1897-1922)" (paper presented at the annual conference for the Association for the Study of Modern Italy, London, UK, November 19-20, 2010), 10 .

${ }^{191}$ Pizzi (2001), 33.

${ }^{192}$ Antonella Pocecco, "Incontro di culture e frammentazione territoriale nell'alto Adriatico: il caso Trieste" ed. Cocco and Minardi, 145.
} 
Consequently, the imperialist and aggressive policies of the fascist regime aggravated antiItalian feelings among the Slavic population in the Julian region and further reinforced aspirations for national self-determination among Slovenes and Croats. The downsides of the fascist attempt to achieve cultural and ethnic homogenization visibly manifested themselves on the eastern border during the last few years of the Second World War. ${ }^{193}$ Any claim that stressed the Italian territorial nature of the Adriatic border was mainly understood by the Yugoslav Communist resistance as a residual expression of Italian Fascism and its proponents became victims of a wave of violence and repression that was accompanied by the dramatic experience of the "foibe." Among the Italian speaking population of the eastern border, however, the defense of Trieste's Italian identity was rescued by a small group of intellectuals who provided it political legitimacy after September 8 , 1943.

In connecting to Mazzinian conceptualizations of national identity, the Julian democratic resistance reasserted the Italian identity of Trieste and its Istrian region and advocated the continuity of Italian statehood in the region. This effort, however, was strongly undermined by the ambiguous role of the Italian communist resistance whose support for Tito's partisans adversely affected Italian claims on the border. Moreover, after 1943 the wartime Allies also debated the future settlement of the post-war Italian eastern border in diplomatic talks which, revealing the gradual divergence of Soviet-Yugoslav and Anglo-American views on the political fate of Trieste and its Istrian region, paved the way to its territorial partition.

In conclusion, the importance of Adriatic irredentism was gradually undermined by the nationalist impetus of the late nineteenth-century, the years of the Great War, national Fascism, and the complex experience of resistance, all of which radically transformed earlier ideas of "Italianità." Traditionally associated with the ideals of Risorgimento and national patriotism, "Italianità" became synonymous with revanchist and aggressive Italian nationalism. Within a national and international context that shaped the formative stages of what became the "Trieste question," a small group of

\footnotetext{
${ }^{193}$ For a study that emphasizes the hybrydity of Trieste, see David Laven and Timothy Baycroft, "Border Regions and Identity," European Review of History 15 (3) (June, 2008): 255-275.
} 
intellectuals and political leaders used nineteenth-century ideas of "Italianità" to legitimize the extension of Italy's eastern border and Trieste's role as a barrier to the Slav-Communist threat. After 1945, however, the new Republic, torn between the need to defend its sovereignty of the Triestine territory and an unfavorable diplomatic context, searched for a compromise that prolonged Trieste's occupation for nine long years. 


\section{Chapter Two}

\section{From Occupation to the London Memorandum 1945-1954: Trieste's Broken Statehood and Contested "Italianità" on the Eastern Border}

The end of the war cast serious doubt on the future territorial status of the Adriatic border. Together with the problematic definition of Italy's northern border with its Austrian neighbor, the “Trieste question" monopolized Italian foreign policy until 1954. Italian diplomatic efforts to preserve national sovereignty over the eastern border were greatly influenced by the Cold War. ${ }^{217}$ American diplomat Adlai Stevenson effectively summarized this inescapable interdependence between national foreign policy and post-war international politics by stating that "any individual political acts may have an importance far beyond their local consequences." ${ }^{, 218}$

While coping with the new dynamics of the Cold War, the Italian government also had to respond to widespread public concern for the possible territorial loss of Trieste and its Istrian region. As discussed in the previous chapter, the experience of national resistance was presented by the governmental coalition as a re-generative experience for the whole nation which, in upholding Mazzini's ideas of self-determination, had opposed Nazi-fascist occupation and strove to defend Italian national borders. ${ }^{219}$ As a consequence, after the signing of the 1947 Paris Peace Treaty and the formal creation of the Free Territory of Trieste (FTT), the defense of the border's "Italianità" and the re-affirmation of Italian sovereignty over Trieste and its territory became powerful political tools used not only to mobilize a defeated nation but also contest the terms of what was depicted as a dictated peace.

The postwar government's firm defense of Italian sovereignty over the FTT, however, was opposed by Communist and local independent political movements which advocated the partition or the internationalization of Trieste and its territory. Italian hopes of rule over the territory initially

\footnotetext{
${ }^{217}$ See Christopher Duggan and Christopher Wagstaff (ed.), Italy in the Cold War: Politics, Culture, and Society, 1948 1958 (Washington D.C.: Berg, 1995).

${ }^{218}$ Roberto Rabel, Between East and West: Trieste, the United States, and the Cold War, 1941-1954 (Durham: Duke University Press, 1988), ii.

${ }^{219}$ Manlio Graziano, The Failure of Italian Nationhood: the Geopolitics of a Troubled Identity (New York: Palgrave MacMillan, 2010), 153.
} 
overlapped with the Anglo-American goal of containing Soviet communism and limiting the gains of its Yugoslav ally; however, when Tito's regime suddenly split from Moscow and proclaimed its new policy of non-alignment, the "Trieste question" turned into a source of geo-political tension between the new Republic and the Western Allies. Post-war Italian foreign policy, which had trumpeted the ideals of European and Atlantic unity, was now forced to face one of the internal contradictions of Cold War politics: the reconciliation of conflicting national and international interests. To respond to the pressure of significant segments of public opinion, political parties and patriotic associations, the national government and its Christian Democratic majority vocally advocated Italian rule over Trieste and its territory.

Over time, however, this strategy risked jeopardizing American efforts to distance Tito from the Soviet sphere and to bring Yugoslavia closer to the West. Until 1954, Washington and Rome attempted to resolve this conflict of interest that had poisoned their diplomatic relations and fostered mutual misunderstanding. Belgrade, on the other hand, significantly benefited from the new views of the American administration. Guided by Western needs for peace and stability in the region, American pressure and staunch diplomacy eventually led to a compromise between Italy and Yugoslavia. This compromise, while partially deflating local irredentist dreams, also forced the Italian government to re-think its post-1954 politics of identity toward the Adriatic border.

\section{Post-war Trieste: from the Morgan Line to the Paris Peace Conference}

"It was therefore necessary to induce them to go away with all sorts of pressures. So we were told and it was done." ${ }^{220}$ With these words, Milovan Djilas remembered when, in 1946, he and Edvard Kardelj went to Istria to organize anti-Italian propaganda and legitimize in ethnic terms the territorial demands of the Yugoslav government at the Paris peace conference. The forced emigration of the Italian minority in Istria was an integral part of the war experience on the eastern border and became a powerful means to advance post-war Yugoslav territorial interests. The early

\footnotetext{
${ }^{220}$ Petacco, 14.
} 
years of the Cold War, however, provided Italy the most favorable domestic and international context for challenging Tito's claims on the Adriatic frontier.

On May 21, 1945, after an uninterrupted series of diplomatic negotiations, the Allied and Yugoslav governments established the provisional division of Trieste along the Morgan line. ${ }^{221}$ On June 9, 1945, the territorial partition was officially sanctioned with the Belgrade agreement and Trieste was freed of Yugoslav troops. ${ }^{222}$ This agreement, however, did not bring an end to the wartime suffering of its inhabitants, in particular the Italian population which experienced a mass exodus from the Adriatic region; ${ }^{223}$ rather, the émigrés who arrived in Italy were depicted by the parties of the left as fascists escaping from the Eastern lands under Yugoslav control and became victims of sporadic episodes of popular intolerance and denigration. ${ }^{224}$

\section{Between June 12, 1945 and October 5, 1954, the Allied Military Government (AMG)} administered Trieste and intensively engaged in a feat of massive propaganda that underscored the goals of post-war economic and social reconstruction. ${ }^{225}$ Initially, the AMG directly ruled the three provinces of Trieste, Gorizia, and Pola. Its head replaced the local "Prefetto" (Prefect) and was supported by the activity of zone Councils. ${ }^{226}$ The AMG also abrogated both the previous Italian fascist and Yugoslav communist legislation. Despite the repeal of fascist laws, the de-fascistization of Triestine society was far from successful. ${ }^{227}$

During Allied occupation, national and local pundits as well as political parties and associations of center-right inspiration continued to call for the reincorporation of Trieste and its territory within the Italian state. Nationalist forces, especially, championed the "Trieste question" by

\footnotetext{
${ }^{221}$ The line was named after the British representative who negotiated with Tito. Rebel, 63.

${ }^{222}$ Italy retained about one-sixth of the territory that was under its sovereignty before the war while the Julian Venetian region and its four provinces, Trieste, Gorizia, Fiume, and Pola, were divided in two separated zones named A and B, under Allied and Yugoslav control respectively.

${ }^{223}$ The post-war exodus of the Italian population from Istria, Quarnero, Fiume, and Dalmatia began in 1946 and went on until the 1960s with its peaks in 1947 and 1953. The public oblivion that surrounded the issue adversely affected the rights of the émigrés whose property became the subject of a long and still ongoing dispute. See Piero Delbello, Esodo (Trieste: I.R.C.I., 2004).

${ }^{224}$ Petacco, 120 .

${ }^{225}$ See SimonaTobia, Advertising America. The United States Information Service in Italy (1945-1956) (Milano: LED Edizioni Universitarie, 2009).

${ }^{226}$ See Monica Rebeschini, “Organigrammi e Carriere nel GMA dellaVenezia Giulia," in Dopoguerra di confine, ed. Tullia Catalan, Giulio Mellinato and Pio Nodari (Trieste: Tipografia Adriatica, 2007), 113-125.

${ }^{227}$ Hametz (2005), 38.
} 
presenting themselves as the sole defenders of Italian sovereignty over the Adriatic region. ${ }^{228}$ Italian nationalist and neo-fascist movements invariably profited from the Triestine problem in an effort to regain political legitimacy and consensus after the ignominy of Italian Fascism and the dramatic experience of World War Two. ${ }^{229}$ In an attempt to directly link the territorial defense of the border to irredentism rather than fascism, these movements relied on the emotional leverage of Trieste's Italian identity ${ }^{230}$ however, their nostalgic and aggressive tones only partially succeeded in winning national popular support. ${ }^{231}$

Indeed, in an article published in Italia Libera on July 6, 1945, Gianni Stuparich, a significant voice of the Triestine Committee of National Liberation (CLN), condemned the fascist expropriation of the national myth of Trieste. Stuparich reasserted the specific national rather than nationalistic meaning of the borders established after the Great War that made Trieste an Italian city and fulfilled the goals of national unification. To legitimize the extent of Italian statehood to Trieste and its territory, leaders of the Republican Party exalted the continuity among patriots of "Risorgimento" and resisters of World War Two. They argued that their actions made it possible not only to legitimately dispute Tito's claims on the Adriatic border but also prove the Italian nature of Trieste. ${ }^{232}$ By contrast, both socialist and communist segments of national public opinion advocated the independence of the Julian city and its territory as a shield from Tito's annexationist ambitions, which were perceived as a "pretext for nationalist forces."233

Competing political views well reflected the diversity, uncertainty, and fragmentation of both national and local public opinion as proposed solutions to the "Trieste question" became polarized according to ideological dichotomies of East vs. West and Communism vs. Democracy. ${ }^{234}$

\footnotetext{
${ }^{228}$ Marco Mapelli, "La destra italiana e la questione di Trieste (1946-1954): la ricerca di una rileggitimazione italiana," Quaderni Giuliani di Storia (2) (1987): 26.

${ }^{229}$ See Istituto Regionale per la Storia del Movimento di Liberazione nel Friuli-Venezia-Giulia, Nazionalismo e neofascismo nella lotta politica al confine orientale 1945-1975 (Trieste: IRCM, 1977).

${ }^{230}$ See Claudio Tonel, Dossier sul neofascismo a Trieste (1945-1983) (Trieste: Edizioni Dedolibri, 1991).

${ }^{231}$ For a comprehensive analysis of the phenomenon of neo-fascism in the early years of the Republic see Giuseppe Parlato. Fascisti senza Mussolini: le origini del neofascismo in Italia, 1943-1948 (Bologna: Il Mulino, 2006).

${ }^{232}$ Rodolfo Pacciardi, “Tito a Trieste,” La Voce Repubblicana (May 8, 1945).

${ }^{233}$ Foreign Broadcast Information Service (FBIS), (April-May, 1945).

${ }^{234}$ Pupo (2007), 140.
} 
In Trieste, especially, Slovenians became a national minority within a non-Slavic city whose identification with Tito's Yugoslavia was increasingly perceived by the Italian Triestines as a threat to the Italian identity of the city. ${ }^{235}$ Consequently, political anxiety and insecurity toward the future territorial settlement of the border inflamed relations between the Slovene and Italian populations and produced local incidents. In commenting on the local mass demonstrations of late 1945, the American Political Adviser in Trieste clearly predicted an increase in urban violence. In his report, he wrote that over the last few months local pro-Italian parties had been increasingly determined "to counteract aggressive pro-Yugoslav propaganda" and their activities "might result in overt clashes and violence." 236

In addition, another report from the US Embassy in Rome confirmed that "local disorder provoked criticisms of the AMG for having failed to protect Italian citizens from attacks by filoSlav elements. ${ }^{2237}$ In line with such criticisms, local nationalists claimed that Allied authorities' mild attitudes toward the strong and organized communist propaganda could easily lead to another Yugoslav occupation. In a city like Trieste, these fears fostered a steady sense of endangerment among the Italian local population and consequentially the AMG quickly became the main target of popular grievances.

In response to local needs for security and stability, the AMG initially created municipal and fire forces from the Italian police corps and entrusted local administration to personnel mainly coming from the British service until 1947, the year in which the American presence became predominant. By 1946, the "Venezia Giulia" (Venetian Julia) police force, led by Anglo-American commanders, could count on approximately 3,500 members, the majority of which was made up of members of Italian non-communist partisan formations, state police, and both communist and

\footnotetext{
${ }^{235}$ Minca, 272.

${ }^{236}$ National Archives and Records Administration (NARA), RG 84 Foreign Service Posts of the Department of State (Fsp), Rome Embassy and Consulate General Records 1945, United States Political Adviser Allied Headquarters, Trieste, November 10, 1945, Box 144.

${ }^{237}$ NARA, RG 84 (Fsp), Italy U.S. Embassy, Rome Classified General Records 1946-1964, "Report on Trieste,” August 14, 1946, Box 6.
} 
partisan Slav units. ${ }^{238}$ This police force, however, became the object of uncompromising criticism and attacks by Slav-communist propaganda which depicted it as an "army serving reaction, acting as an instrument of dark forces of the Fascist organization of CLN." ${ }^{239}$ As this passage shows, local governmental institutions were attacked by both nationalist and communist propaganda which weakened their popular support and fueled political extremism.

In addition, Moscow's open support of Yugoslav annexationist claims to Trieste aggravated the fears of the local Italian community. Coinciding with negotiations at the Paris peace conference, demonstrations in support of Trieste's "Italianità" were paralleled by acts of sabotage and terrorism against the AMG as well as violent clashes between Italian and Slav segments of the local population. An Allied report on the political situation of July 1946 stated that "neither side agrees with the decisions of the foreign ministers to internationalize Trieste" and even though representatives of the local CLN called for cooperation with Slovenes in a future Julian Free State, these views did not "represent the majority of their countrymen." ${ }^{240}$ For months, indeed, mass demonstrations of solidarity for Trieste spread from Milan to Palermo and accompanied the negotiations of the Paris peace talks. ${ }^{241}$ In commenting on these negotiations, Prime Minister Alcide De Gasperi firmly reiterated Italy's opposition to any territorial renunciation of Trieste and the northern part of the Istrian region. ${ }^{242}$

\footnotetext{
${ }^{238}$ Undergoing strict physical and physiological examinations these units were open to female participation only in 1949. Since 1948, 200 members of these units made up the special unit "Nucleo Mobile" which played a crucial role in the following years to suppress protests and demonstrations and become the main object of Italian accusations of AMG responsibility for the deaths of November 1953 (discussed in detail later in this chapter). For an exhaustive study on the local police forces see Vittorio Leschi, Le milizie triestine (Mariano del Friuli: Edizioni della Laguna, 2006).

${ }^{239}$ NARA, RG 84 (Fsp), Italy U.S. Embassy, Rome Classified General Records 1946-1964, "Report on Trieste,” August 14, 1946, Box 6.

${ }^{240}$ NARA, RG 84 (Fsp), Italy U.S. Embassy, Rome Classified General Records 1946-1964, "Report on Trieste 1946," July 31, 1946, Box 6.

${ }^{241}$ FBIS (June-December, 1946).

${ }^{242}$ Alcide De Gasperi was born in 1881 in Pieve Tesino, a small village near the northern city of Trento, AustriaHungary. In 1911, De Gasperi was elected to the Austrian Parliament as an Italian representative and supported the annexation of Trentino by Italy. After the region was incorporated inisde Italy's borders, De Gasperi was elected to the Italian Parliament and became one of the founders of the Italian Popular Party. During the inter-war years, De Gasperi was first arrested for his anti-fascism and after being released served as a librarian at the Vatican. After 1943, he became the secretary of the Christian Democratic Party and from 1945 to 1953 remained in office as Prime Minister. A fervent Europeanist and anti-Communist, De Gasperi was strongly supportive of US foreign policyduring the Cold War and died in Sella di Valsugana (Italy) in 1954. See Pier Luigi Ballini, Alfredo Canavero, Francesco Malgeri, Alcide De Gasperi (Catanzaro: Soveria Mannelli, 2009).
} 
Political as well as popular desires and expectations, however, badly fit the new reality of international politics. In 1946, The Nation, one of the leading American magazines devoted to politics and culture, described the narrow territory of the Julian Venetian region, calling it as "a concentrated example of the bitter fruits of our victory over fascism. ${ }^{243}$ For the American magazine, the Julian case best exemplified the shameless reality of power politics which, instrumentally presented as a competition between Latin and Slav civilizations, hid the real nature of the problem: the geo-political competition between East and West for the magnificent harbor. The magazine strongly criticized the pro-Italian bias of the AMG which further complicated the cumbersome process of reconciliation between Slovene and Italian inhabitants of the region. It correctly highlighted that the Triestine common man proved little interested in the political nature of the dispute and was eager to restore past Habsburg prosperity. Trieste's economic and social reconstruction, however, became a prominent goal of the Allied administration only after 1947. Instead, throughout 1946 and 1947 the Italian government and the Allies financially and militarily supported a variety of socio-political movements that, according to historian Spazzali, gathered under the umbrella of "Second Irredentism." ${ }^{244}$ This secret network was created to oppose Yugoslav communism and its local political formations. ${ }^{245}$ In a report of 1946, the US Political Advisor to Rome described in detail the structure of one of its formations, the "Fronte Unico di Italianità” (United Front of Italianess, FUDI). This military organization could count on approximately 800 members and mobilize a network of 9000 men to oppose an eventual Yugoslav

\footnotetext{
${ }^{243}$ G.E.R. Geyde, "Reflections in Trieste," The Nation (October 5, 1946).

${ }^{244}$ See Roberto Spazzali. Secondo irredentismo: tra patriottismo democratico e rivendicazione integrale dell'italianità sulla Venezia Giulia (Trieste: Università di Trieste, 2011).

${ }^{245}$ Beginning with 1946, officers of the Italian secret service financed and armed both Italian ex-partisans and neofascist squads, secretly aiming to carry out a coup d'état and establish a fascist Republic in cooperation with monarchic forces. Among them, the "Folgore" (Lightning) unity also benefited of the support of the American secret services and cooperated with ex-Nazi officers for anti-Yugoslav actions on the Adriatic border. In 1947 about 10,000 members of the third division of "Corpo Volontari Libertà" (Freedom Volunteers Corp), mainly made up of Osoppo brigades and a tiny representation of moderate ex-fascists and neo-fascists, joined rightist military units in the territory. The CVL could count on a total of 35,000 armed men under the leadership of General Raffaele Cadorna. Colonel Giovanni Messe was appointed as the head of the anti-communist movement in Northern Italy. These forces benefited from American support on all territory but the FTT, momentarily left out to not interfere with the ongoing peace talks. See Nicola Tranfaglia. La “Santissima Trinità.” Mafia, Vaticano e servizi segreti all'assalto dell'Italia (Milano: Bompiani, 2011), $176-213$.
} 
coup. $^{246}$ Other such organizations appeared on the Adriatic border and the American Information Service documented the creation of clandestine cells of neo-fascists both inside and beyond the provisional Morgan Line. ${ }^{247}$ These secret cells opposed Yugoslav rule in Istria by means of propaganda and sought to expose Yugoslav repressive policies toward the Italian minority. This practice, also broadly appearing inside the pages of La Voce Libera, was used to validate rumors of a possible Yugoslav occupation. ${ }^{248}$

Most important is the fact that while supporting Italian sovereignty of the border, a panoply of movements and associations of moderate as well as extremist nationalist orientations, which I later refer to as neo-irredentist, ultimately attempted to rally a nation in ruins around the "Trieste question" and its patriotic meaning. Among them, the "Lega Nazionale" (National League, LN) played a pivotal role to promote the idea of Italian statehood on the border as the best guarantee of independence and liberty from the oppressive policies of the Titoist regime. ${ }^{249}$ Communist propaganda responded to the pro-Italian campaign of the association by equating "Italian sentiment to fascist ideology." ${ }^{250}$ On March 19, 1946, the National League publicly announced its program and in May 1946, after months of internal debates and discussions, it approved a provisional statute. It clearly supported the promotion of "Italianità" among the local population in educational, recreational, and cultural activities that were funded by benefactors, membership fees, governmental contributions, and the local political network.

Support for the activities of associations such as the National League was part of a broader governmental strategy. Due to the necessity to compensate for diplomatic weakness and cope with

\footnotetext{
${ }^{246}$ NARA, RG 84 (Fsp), Italy U.S. Embassy, Rome. Classified General Records 1946-1964, Top secret, No.259, US Political Advisor, American Embassy, Rome, May 2, 1946, Box 6.

${ }^{247}$ Since 1945 both a pro-Soviet information network and an anti-communist organization was active on the Julian border. Anti-communist squads were organized and both military and financially supported by the Italian government which also benefited from the cooperation and acquiescence of local Masonry and relevant political figures, among them the future Christian Democrat and Triestine mayor Marcello Spaccini, as well as the anti-Titoist communist leader Vittorio Vidali. These relations between national elites and political extremists are based upon the information contained inside the diary of local war collector Diego de Henriquez and outlined in Maranzana (2001), 49-63.

${ }^{248}$ FBIS (May, 1946).

${ }^{249}$ Andrea Vezzà e Pitero Comelli, Trieste a destra. Viaggio nelle idee diventate azione lontane da Roma: dalle origini del Msi alla svolta di An, dalla fusione nel Pdl allo strappo dei futuristi (Trieste: Battello Stampatore, 2013 ), 23.

${ }^{250}$ Roberto Spazzali, Contributi di ricerca per una storia della Lega Nazionale 1946: la ricostituzione (Trieste: Edizioni Trieste Press, 1987), 13.
} 
the Allied military occupation and the perceived Yugoslav threat, the Italian government created a special office for the border areas: "Ufficio Zone di Confine" (Office of Border Zones, hereafter,UZC). ${ }^{251}$ The UZC, located in Rome and connected to the Ministry of Interior, was directed by Silvio Innocenti. ${ }^{252}$

In a 1945 letter to the Ministry of Interior, Innocenti wrote that "even though Fiume was publicly perceived as a symbol of fascist adventurism, it rather represented the center of "Italianità" in Eastern Istria and a strategic part of the Danubian railways." ${ }^{, 253}$ In stressing the Italian nature of the city, its indissoluble economic ties to Trieste, and its role as a center of Italian culture in the Adriatic, the letter reveals a pronounced irredentist tone and provides an interesting example of the motives that drove the actions of the UZC. The Ministry of Interior indeed controlled military groups, orchestrated pro-Italian propaganda, and exercised informal pressures on local and national authorities. ${ }^{254}$ It also greatly benefited from the presence and activities of significant Catholic figures and organizations both in Trieste and in the Istrian region, among them Bishop Antonio $\operatorname{Santin}^{255}$ and Catholic priest Don Marzari. ${ }^{256}$ Likewise, in the area that was subjected to Yugoslav

\footnotetext{
${ }^{251}$ The UZC was created in 1947 to continue the activity of the Office Venetia Julia, originally founded in 1946 and aiming to assist the emigration of Italians from the Adriatic region. The UZC promoted the propaganda of "Italianità" in the border regions by means of financial support to Italian cultural associations, newspapers, and political formations. The UZC mirrored the political culture of the national elite and uninterruptedly supported the "Italianità" of Trieste until 1954 when its named was changed into the "Ufficio Regioni" (Office of Italian Regions). Its documents were made available at the Archive of the Presidency of the Ministry Council only in February 2010 and this dissertation has carried out an in-depth examination of those records, especially for the years from 1954 to 1975. For a description of the archival sources available, see Raoul Pupo, "Fonti e archivi," Quale Storia (2) (December, 2010): 7-79.

${ }^{252}$ Silvo Innocenti was born in 1889 in Florence. He became member of the Fascist Party (PNF) in 1925 and was appointed as Prefect of Rome in 1942 after a career of 24 years. Expert in foreign languages and international law, Innocenti worked in 1943 as Prefect of Taranto during the Allied landing in Sicily. After September $8^{\text {th }}$ he joined the Southern government and worked as head of civil affair. Often labeled as a reactionary and conservative, Innocenti was harshly criticized from communist members of the Badoglio's government for his alleged fascist intemperance and collaboration with the German forces of occupation. Such accusations were dismissed by Prime Minister Ivanoe Bonomi in a letter to De Gasperi on December 18, 1945. In this letter, Bonomi praised Innocenti's role in the Southern government and highlighted the broad support he enjoyed from both officers and academics, among them Benedetto Croce. Innocenti was later appointed as Prefect of Bolzano on January 9, 1946, and after November 19,1946 moved to the Presidency of Council as state advisor. Archivio Centrale di Stato (ACS), Fasc. Permanenti, Prefetture-Prefetti 1944-1966, B.9.

${ }^{253}$ UZC, Sez.II, Fondo Fiume, "Letter from Innocenti to Ministry of Interior," April 8, 1945, Busta 1.

${ }^{254}$ Millo (2011),45.

${ }^{255}$ See Ettore Malnati, Antonio Santin: un vescovo tra profezia e tradizione 1938-1975 (Trieste: Mgs Press, 2003).

${ }^{256}$ Don Marzari, head of Catholic organizations such as "ACLI" or "Opera Figli del Popolo", participated in the Paris Peace conference as an expert on the Julian question and firmly supported the Wilson line by producing documentation and evidence about the Italian nature of the Adriatic urban centers. Don Marzari, embracing the values of freedom and national unity set in the Atlantic Charter, assisted the mass of incoming émigrés from the Istrian region and, firmly
} 
military occupation, the Istrian C.L.N. became the strongest expression of post-war Italian resistance to Tito's policy of de-Italianization. ${ }^{257}$

As discussed so far, after 1945 the "unredeemed" city, rhetorically depicted as bastion of Italian civilization, remained central to post-war conceptualizations of Italy's imagined community. Both inside and outside Trieste people mobilized in support of Trieste's "Italianità" and advocated its defense against Tito's Yugoslavia. The Allied authorities, torn between Yugoslav accusations of favoring resurgent Fascism and local fears toward Yugoslav communism, experienced increasingly hostility from both local Italians and Slovenes and attempted to maintain public order. Meanwhile, the Italian government, exploiting the Allies' anti-communism and eager to prove its uncompromising attitude toward any change of the Italian border in the Northern Adriatic, strengthened the Italian front inside Trieste by indistinctly supporting the activities of multiple military groups and associations of democratic or neo-fascist orientation. Despite the efforts of the Italian government, however, the border's fate greatly depended on the decisions that were taken at the Paris peace conference.

\section{The Free Territory of Trieste: an Unworkable Solution}

In Paris, Italian diplomats proved impotent when dealing with Yugoslav territorial claims, strongly backed by the Soviet Union; however, after the Allies' refusal to declare Trieste a free city under Yugoslav sovereignty, Stalin agreed to the French proposal for a new border. ${ }^{258}$ This decision, which settled the borders of the prospective Free Territory of Trieste (FTT), represented a compromise between Soviet views of the economic link of Trieste to the Danubian lands and Allied ideas of its Italian ethnicity. ${ }^{259}$ It is interesting to note that both the US and British representatives perceived the French border line proposal as the "nearest approach to a strictly ethnic solution" yet

\footnotetext{
opposing resurgent neo-fascism, supported the democratization of local youth. See Libero Pelaschiar, Edoardo Marzari: sacerdote in terra di confine (Brescia: Morcelliana, 2003).

${ }^{257}$ See Andrea Vezzà, Il C.L.N. dell'Istria (Trieste: Associazione delle Comunità Istriane, 2013).

${ }^{258}$ Rossi and Zaslavski, 150.

${ }^{259}$ See Map IV.
} 
Map IV: Proposed Borders of the Free Territory of Trieste at the Paris Peace Conference

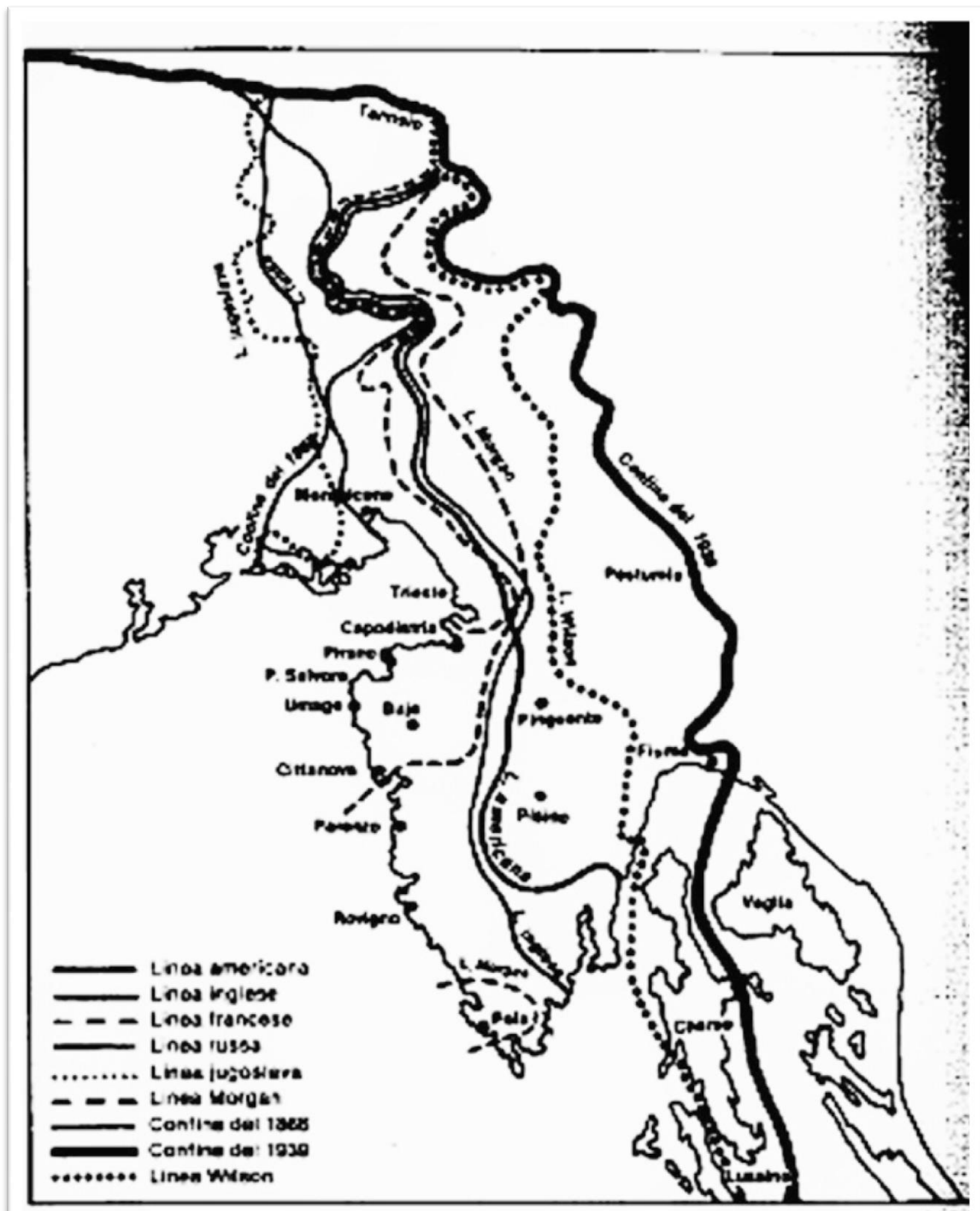

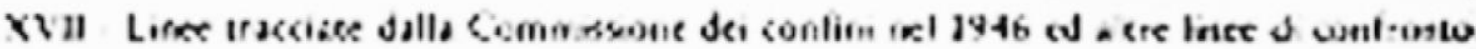


"too restrictive as a boundary for a free territory" and they unsuccessfully attempted to extend it further south. ${ }^{260}$ In addition, the American administration, aware of the uneven Italian and Slav ethnic distribution in urban and rural areas, understood that Italian anxiety over the possible loss of Trieste was acute and its internationalization, in a context whereby its population was overwhelmingly Italian, would only create tension on the path of post-World War One Danzig. ${ }^{261}$ Strongly influenced by domino theories of international politics and aware of the complexity of the Triestine case, the American administration therefore eagerly replaced its British junior partner in the Allied Military Government to prevent communist "diseases and unrest" in the Adriatic region. $^{262}$

Furthermore, Soviet support for Yugoslav requests and Western will to impose a solution suitable to its strategic interests made a popular plebiscite an impracticable option. ${ }^{263}$ De Gasperi, concerned about both the potential results of a plebiscite in the Adriatic region after months of forced de-Italianization and political pressure to agree to a popular plebiscite in other border areas such as South Tyrol, accepted the internationalization of Trieste and its territory. ${ }^{264}$ De Gasperi also hoped to exploit the recurring tension among former wartime allies yet his decision was criticized in many quarters. For example, Ernesta Battisti, wife of the socialist irredentist martyr, attributed De Gasperi's unwillingness to support the idea of a popular plebiscite to his insufficient "Italianità." In her mind, De Gasperi was ethnically Italian yet loyal to Austria and was driven by religious instead of irredentist faith that made him a great politician rather than patriot. ${ }^{265}$ By focusing on De Gasperi's personality, this kind of interpretation unfairly minimized the diplomatic environment which, highly unfavorable to Italian interests, made the chance of upholding past irredentist claims

\footnotetext{
${ }^{260}$ NARA, Records of the Office of the Western European Affairs, 1941-1954, Subject Files, Box 9, "Secret Note on Territorial Question, Italian-Yugoslav Boundary," August 16, 1946.

${ }^{261}$ NARA, National Intelligence Estimates Microfish, R\&A 3467 (945AH3482S/C), December, 1946.

${ }^{262}$ Cristiana Colummi, “Aspetti e problemi della navalmeccanica triestina: i problemi di una crisi," ed. Ganapini, 35.

${ }^{263}$ Ghisilberti (2008), 185.

${ }^{264}$ See Gianni Giuricin, "Il plebiscito a Parigi e Copenaghen,” in La sconfitta rimossa: 1947-2007 a sessant'anni dal trattato di pace, ed. Delbello Piero e Roberto Spazzali (Trieste: IRCI, 2008), 63-91.

${ }^{265}$ See Ernesta Battisti, Italianità di De Gasperi (Firenze: Parenti Editore, 1957), 60-71.
} 
on Trieste and its Istrian region untenable, whatever the personal beliefs and orientations of the Italian leader.

On February 10, 1947 the Peace Treaty was signed in Paris and postulated the partition of Trieste and the northern part of the Istrian region, under Anglo-American and Yugoslav administrations respectively. ${ }^{266}$ The Peace Treaty strongly reduced Italian influence in the Adriatic and Balkan regions and forced Italian post war foreign policy to accommodate itself to the bipolar logic of the Cold War, even if the restoration of national sovereignty of Trieste and its hinterland remained a formal goal of the new Republic. ${ }^{267}$ De Gasperi, indeed, publicly called for a "passionate revolt at the unmerited fate of the Italian people of Trieste and Pola... who he cannot save,"268 stating that "Italy won't leave you alone... there are no borders able to break kinship.." ${ }^{269}$ De Gasperi's speech was followed by demonstrations of workers, former partisans, and war veterans who came to Italian cities with flags of Fiume, Dalmatia, and Istria to show popular opposition to what was perceived as an "unjust peace."

As a consequence of the Peace Treaty, Italian emigration from the Yugoslav region further accelerated and peaked between $1947-1949$, rising to 50,000 people. ${ }^{270}$ The incoming émigrés were dispersed across the peninsula, fled abroad, or were victims of a campaign of public denigration and politically ostracized. ${ }^{271}$ Pro-governmental newspapers such as Il Corriere della Sera proved sympathetic toward the incoming Italians and used the exodus to endorse national claims over the

\footnotetext{
${ }^{266}$ The Treaty sanctioned the Italian loss of all its colonies (Libya, Dodecanese islands, Eritrea, Somalia, Ethiopia, Tientsin in northern China and the Sazan island in Albania), the territory on the Eastern borders to the advantage of the reborn Yugoslav state, the permanence of the South Tyrol inside the Italian border regardless of the Austrian claims, the payment of the war reparations, and restrictions on the weapons of the Italian Army.

${ }^{267}$ Bucarelli (2008), 19.

${ }^{268}$ FBIS (February, 1947).

269 "Promessa della patria ai figli suoi piú colpiti," Difesa Adriatica (September 18, 1947).

${ }^{270}$ During the Istrian exodus, which mainly affected the Italian middle class, people called for the exercise of the "right of option" as postulated in the Italian-Yugoslav agreement. This right was made more visible in 1952 by the activity of the Committee for the defense of Italians that provided the émigrés the right to choose between Italian and Yugoslav citizenship and be compensated for their abandoned properties.

${ }^{271}$ Incoming émigrés were among the main targets of the national PCI and depicted as fascists, a general representation that only partially reflected their political views. Togliatti himself defined the exodus as a maneuver of the national government that aimed to discredit the friendly Yugoslav regime. See Marco Clementi, L'alleato Stalin: l'ombra sovietica sull'Italia di Togliatti e De Gasperi (Milano: Rizzoli, 2011), 191-237.
} 
Istrian region. ${ }^{272}$ At the opposite end, the communist journal L'Unità instead stressed that for the first time in history, "it is the population who reasserts its rights on lands inhabited for centuries to voluntarily leave those lands to people of different nationality.",273

In line with former articles that depicted Yugoslavia as the worker paradise and minimized the drama of the Italian population along the border, L'Unità portrayed the exodus as the outcome of the political intrigues orchestrated by the Italian government to assert its rule of those lands. Examination of the personal accounts and judicial-political declarations of the Julian émigrés, however, debunks the distortions of both the Communist Party and its propaganda. Italian citizens who escaped from the zone B reported the planned and coordinated nature of communist violence against elements of pro-Italian sentiments as well as associations of clear Italian inspiration, especially those related to the Catholic Church. Their accounts stressed the inhumane suffering and treatment of priests and nuns in the prison of Stara Gradiska. In addition, they reported Yugoslav torture, bans to celebrate Mass, as well as mass arrests and expulsions from local convents that later became boarding houses for Communist students. ${ }^{274}$

Pola, one of the main Italian urban centers on the Adriatic shore was also assigned to the new Yugoslav Federation by the Paris Peace Treaty. To protest this decision, Maria Pasquinelli, an unrepentant fascist, murdered the Allied General in that city, Robert De Winton. A New York Times article depicted the assassin as "dry-eyed, cold and calculating" with no regret for her actions. Pasquinelli defended the murder by claiming it was revenge for the Allies' decision to strip Pola from the new Republic. Due to the lack of any connection between her action and any organized conspiracy, the article partially minimized its importance yet pointed out the existence of an "Italian tendency to regard her as a martyr."275

\footnotetext{
${ }^{272}$ The Corriere della Sera stressed the senselessmess of the discussion surrounding the Italian Venetian Julian region. A territorial disposition made with the consensus of the Allied powers in 1920 was now disputed by the same powers and promised to reinvigorate Italian nationalist claims . Rinaldo Caddeo, "La questione di Trieste," Il Corriere della Sera (May 23, 1947).

${ }^{273}$ Luigi Longo, “Chi ha ingannato i fratelli di Pola?” L'Unità (February 14, 1947).

${ }^{274}$ Istituto Regionale per la Cultura Istriana (IRCI), Fondo CLN, “Dichiarazioni Politiche,” DP 1.

${ }^{275}$ W.H. Lawrence, "Pola Assassin not Sorry," The New York Times (February 12, 1947).
} 
Pasquinelli's case, rather than proving the endurance of fascist sympathies among the local population, clearly exemplified local fears and anger toward the Western Allies which were publicly perceived as responsible for the upcoming Yugoslav administration. In Trieste these sentiments were partially mediated by the presence of the AMG, publicly perceived as a barrier to Tito's plans for the annexation of the city. American officers indeed emphasized that, despite the low status of local public morale, "a great reservoir of good-will towards the Allies should not be dissipated"276 yet recommended that actions be taken to compensate for the weakness of Italian propaganda which implicitly benefited the local Communist movement. ${ }^{277}$

Nevertheless, the fear of a possible Yugoslav infiltration that could remove local anticommunists and pave the way for a pro-Communist plebiscite seemed untenable, even to the AMG. The American intelligence confirmed that the local Italian front, mainly consisting of former soldiers and neo-fascists, could now count on a force of about 8000 men in the Osoppo brigades in the Northern area of the region and 2000 men in the Julian division that operated in the Isonzo area. ${ }^{278}$ These forces represented a valuable counterforce to the eventual penetration of 3500 Yugoslav communist partisans. ${ }^{279}$ At the same time, however, they could become an additional threat to the precarious socio-political stability of the city whose Italian majority greatly feared Trieste's Balkanization. $^{280}$

Indeed, the Allies proved increasingly concerned about achieving a diplomatic solution to temporarily minimize political tensions over the Adriatic city. Consequentially and notwithstanding Italian and Yugoslav protests, on September 15, 1947 the United Nation Security Council formally

\footnotetext{
${ }^{276}$ NARA, RG 59 Records of the Office of Western European Affairs, 1941-1954 Subject Files, 1947, “Observation of Demonstration in Trieste," May 1, 1947, Box 9.

${ }^{277}$ NARA, RG 59 Records of the Office of Western European Affairs, 1941-1954 Subject Files, 1941-54,

"Memorandum on Italian Government Activities in zone A, Venezia Giulia," May 7, 1947, Box 9.

${ }^{278}$ These military units, trained and supported by members of both the Italian and American military intelligence, became the backbone of the "Stay Behind" network or "Gladio" organization which was formally established in 1956 to resist a possible Communist invasion of the Warsaw Pact. Vezzà and Comelli, 67.

${ }^{279}$ NARA, RG 84 (Fsp), Department of State, Italy; Free Territory of Trieste. Allied Military Government, BritishUnited States Zone. Office of the U.S. Political Adviser, Classified General Records, 1945-1954, “Osoppo and Julia Anti-communist Military Units in Italy," May 23, 1947, Box 2.

${ }^{280}$ Giampaolo Valdevit, "Labour Policy del Governo Militare Alleato (1945-1954),” ed. Ganapini, 259.
} 
proposed the establishment of the Free Territory of Trieste. ${ }^{281}$ This provisional solution was never implemented and for the next nine years, the territorial sovereignty over Trieste and its territory remained contested between the new Italian Republic and Yugoslav Federation. ${ }^{282}$ Within national and international public discourse, Trieste became the "Berlin of the Adriatic," a crucible of ideological conflict and a pawn in international politics. ${ }^{283}$

Most important, the formal announcement of the FTT did not alleviate social unrest inside Trieste. Throughout 1947, the city was a theatre of daily violence and crimes whose ethnic-political tones fueled local disorder. The widespread presence of deposits of weapons and munitions further benefited local political extremism and aggravated Allied concern for public order. ${ }^{284}$ Reports from the Allied Military Headquarter in Trieste portrayed a city deeply divided among pro-Italian, proYugoslav, and independent political groups. The Italian front coalesced around the National League which could mobilize up to 140,000 people and was led by a council of seventeen members of all political orientations except the Communists. In presenting itself as the direct heir of Adriatic irredentism, the association opposed the decisions of the Paris Peace Conference and gradually intertwined its propaganda with that of other political formations inside the region, in particular the "Giunta d'Intesa" (Junta) which replaced the Triestine CLN. ${ }^{285}$ The National League under the leadership of members of the local bourgeoisie and prominent intellectuals, mobilized public

\footnotetext{
${ }^{281}$ See Official Records of the Security Council, Second Year, Supplement No.1, annex 2.

${ }^{282}$ See Map V. This area occupied a space of $741 \mathrm{Km}^{2}$ of which 222 belonged to zone A and 529 to zone B. The total population was 330,000 , of which $84 \%$ were Italians, $15 \%$ Slavs, and the remaining $1 \%$ represented other different ethnicities. Most reliable estimates claim that around 300,000 Italians emigrated from Istria and Dalmatia between 1943 and 1956. In regards to the ethnic composition of the population living in Trieste (zone A) and its surrounding area (zone B), in particular the Istrian region, most reliable data state that in the 1920s there were 211,000 Italians, 32,000 Slavs, and 18,000 Germans in zone A. Instead in zone B there were 54,651 Italians, 16,287 Slavs, and 200 Germans. In 1947, Italians in zone A were 232,000, Slavs were 25,000 and Germans were 4,000. In zone B there were 45,651 Italians and 24,000 Slavs. Between 1947 and 1956, scholars agree that over time approximately 40,000 Italians left from zone B and the Italian speaking population in the area became a minority which gradually decreased in size. ${ }^{283}$ Ara and Magris (2008), 168.

${ }^{284}$ NARA, RG 84 (Fsp), Department of State Rome Embassy and Consulate General records 1947, "Cole Report,” Box 201, 203.

${ }^{285}$ In the early 1950s the Giunta was replaced by the "Comitato per la difesa dell'Italianità" (Committee for the Defense of the Italianess of Trieste and Istria) which carried on local propaganda of "Italianità."
} 
Map V: the Free Territory of Trieste

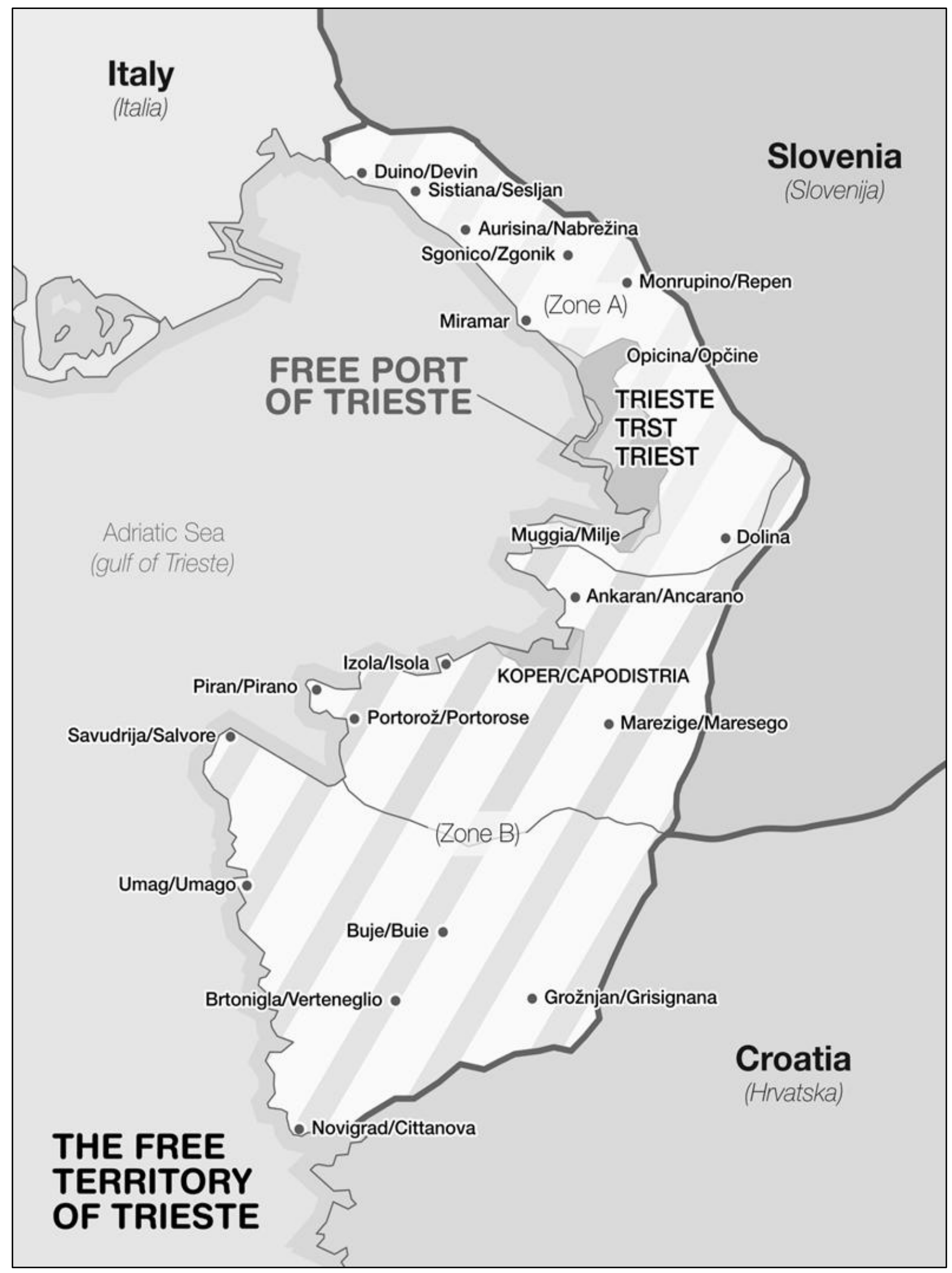


attention around the "Trieste question" by editing and distributing pamphlets in Italian, English and French both at home and abroad. ${ }^{286}$

Local political violence, however, was externally read as a sign of resurgent nationalism and the National League itself was often portrayed by parts of national public opinion as a residual expression of Julian fascism. ${ }^{287}$ In contrast, local scholars such as Spazzali and Redivo have demonstrated that only small fringes of the association were compromised by the petty nationalism of the neo-fascist and extremist right. ${ }^{288}$ In fact, the National League along with cultural associations such as the "Dante Alighieri," and "Università Popolare” (Popular University) promoted ideals of fatherland which were informed by the experience of the Julian democratic resistance. $^{289}$

Likewise, these ideals were echoed outside Trieste and within the pages of patriotic journals such as Il Ponte or Il Pensiero Mazziniano. ${ }^{290}$ These journals, in particular, advertised the views of multiple cultural and political associations, among them the "Associazione Mazziniana Italiana" (Italian Mazzinian Association, AMI). ${ }^{291}$ Although this patriotic association and Julian intellectuals highlighted Trieste's coexisting national and European identity, post-war nationalist and socialist political cultures continued to read the Trieste's reality through the lenses of nationalism, ethnicity, or class. ${ }^{292}$ As a consequence, expressions of "Italianità" were easily labeled as fascist and, more importantly, any solution that did not imply the return of Trieste and its Istrian region to Italy was labeled as anti-Italian and pro-Communist.

\footnotetext{
${ }^{286}$ NARA, RG 84 (Fsp), Department of State, Italy: Free Territory of Trieste. Allied Military Government, BritishUnited States Zone. Office of the U.S. Political Adviser, Classified General Records, 1945-1954, US Political Adviser Trieste, “Transmitting Report on Lega Nazionale," December 15, 1947, Box 2.

${ }^{287}$ Spazzali (1987), 122.

${ }^{288}$ See RobertoSpazzali, “Il secondo Risorgimento. Un riferimento non banale a Trieste” Risorgimenti d'Italia (2011): $1-19$.

${ }^{289}$ Ercole Miani, “Con il sangue e il sacrificio dei patrioti è scritta la storia della resistenza e dell'insurrezione” La Voce Libera (April 30, 1948) published in Spazzali (2008), 160.

${ }^{290}$ Silvio Benco, "Trieste in ogni tempo italiana," Il Ponte (Anno IV-N.3, 1948), 289-303.

${ }^{291}$ On August 5, 1946, the AMI sent a note to the 21 representatives of the United Nations to protest the unfair decisions taken by the foreign ministries of the Great Powers on the future territorial borders of the Italian nation which endangered the spirit of brotherhood and solidarity that traditionally prevailed between the Adriatic neighbors. It argued that the forced separation of Italian people sharing cultural, economic, and territorial common roots reinforced rising nationalist and imperialist ambitions of the new Yugoslav nation.

${ }^{292}$ Nuovo e Spadaro, 15.
} 
This proved particularly true for the segments of the local Triestine population whose support for the independence of Trieste and its territory found expression in political movements such as "Blocco Triestino" (Triestine Bloc) or "Fronte per l'Indipendenza dello Stato Libero Giuliano" (Front for the Independence of the Free Julian State). ${ }^{293}$ From 1945 to 1959 the local newspaper Corriere di Trieste became the main voice of the Independence Movement and competed with both the Italian national and Titoist blocs. ${ }^{294}$ Inspired by leftist but not communist orientations, the movement espoused bilinguism and socio-political reconciliation between Italians and Slovenes. The newspaper, financially supported by Tito's regime, provided an interesting solution for a multilinguistic, multiethnic, and independent state. Its views, however, clashed with those of the post-war Julian democratic movement which aimed to extend Italian statehood on Trieste and the northern part of the Istrian region. ${ }^{295}$

Indeed, intellectual and politician Fabio Cusin, the main voice of the Independence Movement, proposed a distinctive conceptualization of Triestine identity which, inspired by Tommaseo's nineteenth-century ideas of Adriatic multi-nationalism, supported the administrative autonomy of the FTT and rejected any form of Italian and Slav nationalism. ${ }^{296}$ Cusin harshly criticized the policies of both national and local governing elite because they exploited traditional patriotism and were either greatly affected by past fascist ideals or driven by peculiar economic

\footnotetext{
${ }^{293}$ Differently from the "Blocco Triestino," the "Fronte per l'Indipendenza dello Stato Libero Giuliano" showed clear pro-Titoist attitudes. Some of their members merged into the Unione Triestina in 1955. ACS, MI, Schedario Partiti Politici 1944-1966, B.106, fasc,312/P, Trieste Movimento Indipendentista, "Unione Triestina," April 16, 1956.

${ }^{294}$ On June 9, 1945, Il Nostro Avvenire, a newspaper in the Italian language published clandestinely in Slovenia and later the official voice of the Titoist regime of occupation, changed its name to Il Corriere di Trieste and presented itself as the democratic and independent newspaper of the region. Since the beginning the journal, with a distribution ranging between 4,000 and 25,000 copies, was driven by the values of anti-fascism and Italian-Slav brotherhood, and even though it recognized that "Trieste is Italian for language and sentiments," the newspaper also highlighted the undisputable economic nexus between the city and its hinterland. Alberto Grassi, "Il Corriere di Trieste" tra propaganda e realtà. Un'interpretazione dell'indipendentismo nel Territorio Libero (Trieste: Hammerle Editori, 2009), 15.

${ }^{295}$ Fabio Cusin, "Attualità di Angelo Vivante" Corriere di Trieste (14/2/1946) primary source published in Giulio Cervani, Gli scritti politici di Fabio Cusin nel "Corriere di Trieste." Gli anni della polemica dura 1946-1948 (Udine: Del Bianco Editore, 1991).

${ }^{296}$ In discussing the historical trajectory of Adriatic irredentism Cusin argued that, within the Italian local national party, separatist rather than cosmopolitan orientations won major consensus and detached the movement from its traditional Europeanism. See the pamphlet "La Liberazione di Trieste" published in Giulio Cervani, Gli scritti politici di Fabio Cusin nel "Corriere di Trieste." Gli anni dell'opposizione ragionata 1949-1951 (Udine: Del Bianco Editore, 1994).
} 
interests. ${ }^{297}$ Refuting common accusations of being pro-Yugoslav, Cusin reasserted his Italian cultural identity by envisioning Trieste's territorial unification with Italy in the future; however, he added, due to the new international and geo-political configuration of the Cold War, the inclusion of the FTT inside national borders was not only unsuitable in the present but also harmful to the protection of the Italian population on the eastern border. ${ }^{298}$

This view was based upon the traditional administrative autonomy of the city, a trait intrinsic to its geo-political DNA. ${ }^{299}$ In inviting national elites to re-think Trieste as the bridge of an open border and use commercial agreements to eliminate mutual distrust between the Adriatic neighbors, Cusin greatly anticipated the post-1954 governmental strategy toward the Eastern border; ${ }^{300}$ in 1947 , however, his message implied the renunciation of national sovereignty over Trieste and its Istrian region and was marginalized within public discourse as it was perceived as pro-Yugoslav.

Until 1947 and differently from both democratic and nationalist parties that persistently opposed the FTT, the Italian Communist Party remained entangled between its competing national and international interests and, while supporting Trieste's internationalization, also criticized the "dictated peace." ${ }^{301}$ Indeed, while recognizing Yugoslav socialism in zone B, Togliatti unsuccessfully proposed a territorial exchange between Trieste and Gorizia and supported the idea of direct talks between Italy and Yugoslavia to settle the Adriatic dispute. ${ }^{302}$ Trieste's communist leader Vittorio Vidali, however, conscious of the problematic issue of Italian identity of Trieste and its territory, understood that the clear annexationist goals of the Yugoslav regime only strengthened resurgent local neo-fascism. Within this context, he argued, Yugoslav misperceptions of Italian

\footnotetext{
${ }^{297}$ Fabio Cusin, “Chiarimento" Corriere di Trieste (6/10/1946) primary source published in Cervani (1991).

${ }^{298}$ Cusin in his pamphlet "l'Italiano, Realtà e Illusioni," opposed the unifying myth of the Italian central state and, defining Italian character as amoral and lacking civic identity, envisioned a radical democratic transformation of local and national society to embrace an overwhelming European rather than national ideal. His harsh criticisms against the national elites, traditionally perceived as weak and corrupted, were echoed by other authors writing on border regions, for example Chabod in Valle d'Aosta and Sestan in Istria. See Giuseppe Trebbi, "Italia ed Europa nel pensiero di Fabio Cusin," ed. Cavazza and Trebbi, 229-247.

${ }^{299}$ Parlato (2007), 150.

${ }^{300}$ Fabio Cusin, "Accordi," Corriere di Trieste (15/4/1947) primary source published in Cervani (1991).

${ }^{301}$ Luigi Cavallo, “Abbiamo firmato la pace che ci è stata imposta dai vincitori," L'Unità (February 11, 1947).

${ }^{302}$ Palmiro Togliatti, “Per l’Italia e per la pace,” L’Unità ( November 17, 1946).
} 
Communism's "sick nationalism" only heightened antagonism among the Slav and Italian segments of the local population and further discredited communist claims in defense of Trieste's

"Italianità." 303

As outlined so far, Italian territorial ambitions over the Adriatic border were strongly affected by the emergence of the Cold War. Indeed, the unattainable goal of establishing the FTT exemplified the irreconcilable views of the American administration and the Soviet Union over the Triestine problem. In implying the renunciation of Italian sovereignty over the fruits of the past irredentist struggle, this solution was firmly opposed by the Italian government which unfailingly continued to advocate for the cause of "Italianità" of Trieste and its territory. In so doing, the central government could count on the support of significant segments of local and national public opinion that also espoused a pro-Italian solution to the "Trieste question." By contrast, minor segments of the Triestine population who were highly influenced by promises of economic prosperity and peace turned to the Independence Movement and supported forms of home rule. This solution, also encouraged by the ambivalent and pro-Yugoslav policy of the Communist Party, clashed with Italian territorial interests and was quickly portrayed by both the government and nationalist propaganda as anti-Italian. Thus, by the end of 1947 Trieste's geo-political status remained uncertain and the political debate was polarized by irreconcilable pro and anti-Italian positions. In 1948, however, abrupt changes in international politics significantly affected Italy's strategy toward the eastern border and further exacerbated local socio-political tensions.

\section{Failed Illusions of 1948}

In the immediate post-war years, economic difficulties and episodes of political violence in Trieste weakened popular support for both the AMG and the Italian government. Thus, in January 1948, a secret report from the Italian representative in Trieste to Rome stressed the necessity to increase political pressure on the Allied government to grant major administrative autonomy and

\footnotetext{
${ }^{303}$ Vittorio Vidali, Ritorno alla città senza pace, il 1948 a Trieste (Milano: Vangelista, 1982), 36.
} 
better respond to the city's needs. The extension of the European Relief Program to the zone A and changes in the territorial configuration of the AMG partially responded to the lobbying of the Italian government. ${ }^{304}$ Its local representatives, strongly anchored to non-Communist and anti-fascist traditions, used both formal and informal channels to negotiate with the foreign administration and capitalize on the apparently positive Allied attitude toward the Italian cause. ${ }^{305}$

The year 1948, however, drastically changed the Allied orientations and represented the turning point for Trieste. Anticipating the Italian elections of April, which took place in a context of international tensions inflamed by the communist coup in Czechoslovakia and the Berlin blockade, De Gasperi attempted to trade concessions on Trieste in exchange for the Italian participation in the nascent Atlantic Pact. On March 20, 1948 the three Western powers issued the "Tripartite Declaration," declaring their willingness to bring Trieste's territory back under Italian sovereignty. ${ }^{306}$ The National League sent a telegram to the Western powers expressing enthusiasm for the proposed return of the FTT to Italy and printed celebratory leaflets that read "with fresh hope in our hearts let us proclaim to the world our only faith: long live Italy." ${ }^{307}$ The emotional impact of the Tripartite Declaration was exemplified by mass demonstrations throughout Italy and student parades from Palermo to Tripoli where they placed an American laurel wreath at the foot of the monument of the fallen soldier. ${ }^{308}$

Moreover, national and local newspapers differently responded to the Allied declaration. ${ }^{309}$ For example, pro-governmental press generally welcomed the Allied proposal while raising the central question of Istria's place within Allied policy and stressing the pronounced economic

\footnotetext{
${ }^{304}$ Valdevit, ed. Ganapini, 246.

${ }^{305}$ See Roberto Spazzali, "La struttura del governo militare alleato a Trieste dal 1945 al 1954," in La città reale. Economia, società e vita a Trieste 1945-1954, ed. Pier Angelo Toninelli et al., (Comune di Trieste: Trieste, 2004), 170177.

${ }^{306}$ De Castro, 263.

${ }^{307}$ FBIS (March 21, 1948).

${ }^{308}$ FBIS (March 24, 1948).

${ }^{309}$ NARA, RG 84 (Fsp), Department of State Rome Embassy and Consulate General Records Joyce Report, "Local reaction to Three-Power Proposal Regarding Trieste," April 1, 1948, Box 226.
} 
interdependence between Trieste and its Istrian region. ${ }^{310}$ The "Associazione Nazionale Venezia Giulia Dalmazia" (National Association Venetia Julia and Dalmatia, ANVGD), founded in 1947 and acting as the leading voice of Julian and Dalmatian émigrés through the pages of its journal Difesa Adriatica, argued that the proposal revealed the unfairness of the Peace Treaty and reinforced the patriotic aspirations of the local Italian communities. ${ }^{311}$ By contrast, the communist press stressed the clear imperialist and purely electoral value of the declaration by emphasizing its negative effects on Tito's search for peace and cooperation. ${ }^{312}$ Similarly, the independent movement portrayed the Allied declaration as a proof of the deceptive Anglo-American strategic actions and interest in the Adriatic. ${ }^{313}$

Indeed, the Allies, aware of the significance of the Triestine problem within Italian national public opinion and disregarding Soviet and Yugoslav hostility, used the "Tripartite Declaration" to strengthen Italian democracy and the Christian Democrats against the communist threat. A dispatch from the American Embassy in Rome confirmed the uncertain climate that anticipated the national elections and emphasized the anti-American nature of both the Italian neo-fascist and communist movements. To forestall a possible communist victory, the Embassy also suggested advancing fictitious proposals for a peace treaty revision and even outlawing the Italian Communist Party. ${ }^{314}$ Another report, by contrast, emphasized how mass demonstrations in Trieste successfully mobilized 80,000 Italians who cheerfully celebrated the prospect of gradual changes in local administration, which were locally interpreted as a clear sign of the gradual return of the city under Italian sovereignty. ${ }^{315}$ Such widespread optimism was also echoed within the American press, which emphasized the value of the three powers' proposal to address the Allied distortion of the Peace Treaty, strengthen Italian anti-communist parties, and make Trieste safe from Yugoslav

\footnotetext{
${ }^{310}$ Alfio Russo, "Il governatore dalla faccia d'angelo ha capito il dramma di Trieste," Il Corriere della Sera (June 30, 1948).

311 “Creare lo spirito del riscatto nel cuore generoso del popolo italiano,” Difesa Adriatica (May 27, 1948).

312“'Il popolo italiano ha capito la truffa all'americana," L'Unità (March 28, 1948).

${ }^{313}$ Fabio Cusin, Corriere di Trieste (April 22, 1948) primary source published in Cervani (1991).

${ }^{314}$ NARA, RG 59 Records of the Office of Western European Affairs, 1941-1954 Subject Files, Dispatch 603 Embassy in Rome, April 12, 1948, Box 9.

${ }^{315}$ NARA, RG 59 Records of the Office of Western European Affairs, 1941-1954 Subject Files, Confidential, "Current developments at Trieste," n. 108, Folder Joyce Report, April 22, 1948, Box 9.
} 
annexationist ambitions. ${ }^{316}$ As these arguments suggest, the Tripartite Declaration aimed to strengthen Western anti-communism at a crucial moment in which both the European Recovery Program and the Berlin question captured the attention of both national and international public opinion.

In the face of Soviet objections and especially after the Italian national elections, the Tripartite Declaration quickly disappeared from the Allied political agenda; despite this, it strengthened both local and national hopes for the affirmation of Italian sovereignty over the Triestine territory and paradoxically aggravated rather than eased political and social tensions inside the city. Indeed, the US political adviser in Trieste reported that, following the Christian Democratic victory in the national elections and fearing violent urban disorders, the Allied authorities turned back numerous communists who tried to enter Trieste between April 27 and May 3. Aware of the massive communist demonstration of the previous year that mobilized over 50,000 people and as a consequence of the recent Allied decisions, the AMG feared a violent confrontation between Italians who composed about $80 \%$ of the city's population and Tito's supporters. ${ }^{317}$ Due to rising hostility of both the Italian and Slav population toward years of prolonged Allied occupation, a report from the Allied headquarters in Trieste also suggested the quick normalization of local politics by holding administrative elections in the city. ${ }^{318}$

Only a few months after the Tripartite Declaration and the elections of 1948, which were rhetorically portrayed in Trieste as a plebiscite of "Italianità," Italian hopes for the reintegration of the Julian city and its territory were dashed by the Soviet-Yugoslav rift of June 28, $1948 .{ }^{319}$ The

\footnotetext{
316،"The Defense of the West”, The New York Times (March 22, 1948).

${ }^{317}$ NARA, RG 59 Records of the Office of Western European Affairs, 1941-1954 Subject Files, Confidential, "Confidential, Current developments at Trieste," n.115, Folder Joyce Report, May 5, 1948, Box 9.

${ }^{318}$ NARA, RG 84 (Fsp), Department of State Rome Embassy and Consulate General records 1948, Major General Airey, "Report of the Administration of the British/United States Zone of the Free Territory of Trieste" July 1 to September 30, 1948, Box 203.

${ }^{319}$ Tito's expansionist strategy in the Balkans, in particular in Greece and Albania, met with rising Soviet hostility, due to its detrimental effect on Soviet influence in the Danubian and Balkan area. Within this context, and based upon the study of unedited archival sources, scholars have claimed that the Trieste question became the "real source of Soviet anxiety over Yugoslav foreign policy" and paved the way to the break in Soviet-Yugoslav relations. See Kevin McDermott and Matthew Stibbe, Revolution and Resistance in Eastern Europe: Challenges to Communist Rule (New York: Berg Publisher, 2007), 22. In addition, new studies have emphasized that Tito's refusal to subject the prospected
} 
Allied attitudes toward Tito's regime changed drastically and decisively ended the tenuous hopes for the reincorporation of the Istrian region inside Italian national borders. ${ }^{320}$ Allied authorities interpreted the Yugoslav-Soviet rift as an invaluable opportunity to weaken the cohesion of the Communist bloc, which led them to rethink their strategies toward the Adriatic border. Commenting on the Tito-Stalin rift, the New York Times foresaw the subtle Soviet instrumental use of the FTT as a means to remove Western forces from the Adriatic, weaken Tito's regime, and boost popular support for Italian communism after its modest electoral results. ${ }^{321}$

The Truman administration initially looked with suspicion upon the new international position of the Titoist regime. In case of an eventual discussion within the UN Security Council, the American administration planned to use the totalitarian nature of Yugoslav communism in zone B to clarify the ineffectiveness of the FTT. ${ }^{322}$ In addition, US observers in Trieste noted that, even though the Tripartite Declaration had closed the door to any option for the creation of the FTT, the return of the disputed territory to Italy was not definitively decided "so long as there remained a chance of bringing Tito into the Western camp or otherwise taking advantage of the Yugoslav situation." 323 Such a phrase exemplified the new attitude of the American administration toward the Triestine problem and highlighted the relegation of Italian territorial claims to Cold War's geopolitical interests. Therefore, Italian hopes to extend national sovereignty over the disputed border were fatally compromised. Within Italian public opinion, however, Tito's excommunication initially endorsed feelings of confidence toward a positive solution of the Triestine question. For

Balkan Federation to the Cominform represented the iceberg of cumulative tensions that since 1945 dominated the Yugoslav-Soviet relations on the Trieste question and made inevitable Yugoslavia's excommunication from the Soviet bloc. The waves of purges inside the Soviet bloc after 1948 aimed to crush any attempt of deviationism and isolate Tito's regime. However, the Western bloc promptly responded to the needs of the Yugoslav economy while Tito profitably embraced a policy of non-alignment in international politics. See Maurizio Zuccari. Il dito sulla piaga: Togliatti e il Pci nella rottura fra Stalin e Tito 1944-1957 (Milano: Nursia, 2008).

${ }^{320}$ The Tito-Stalin rift transformed the Trieste question from a pawn into a burden of the Cold War. The pro-Yugoslav attitude of the American administration toward Tito's regime and its new geo-political position as a buffer between Western Europe and the Soviet bloc undermined Italian territorial claims and transformed communist Yugoslavia into a potential ally to be treated with equal if not major attention.

${ }^{321}$ C.L. Sulzberger, "Yugoslav-Cominform Schism May Heal Europe's Sore Spots: Status of Trieste, Peace Treaty with Austria, Greek War Held to be Linked with Split," The New York Times (August 5, 1948).

${ }^{322}$ NARA, RG 59 Records of the Office of Western European Affairs, 1941-1954 Subject Files, "Covering Memorandum Concerning Questions on Free Territory of Trieste Before Security Council," December 18, 1948 , Box 9.

${ }^{323}$ NARA, RG 59 Records of the Office of Western European Affairs, 1941-1954 Subject Files, 1948, Baldwin Report,

"Possible trend of USSR and Yugoslav Policy toward the Trieste Question," No.14, December 30, 1948 , Box 9. 
example, Il Corriere della Sera, perceived Tito's weakness as an invaluable opportunity to advance national interests on the Adriatic border. ${ }^{324}$ By contrast, the Italian communist movement experienced a significant internal fragmentation between Titoist and Cominformist groups whose divergent views resulted in sporadic episodes of violence along the demarcation line of the FTT and inevitably divided the communist movement. ${ }^{325}$ In Trieste, especially, Italian workers removed Tito's picture from the office of the Communist Party and industrial factories whereas Slovene communists symbolically rejected both Tito and Stalin's ideologies and envisioned a return to Marxism-Leninism. ${ }^{326}$ Although Togliatti initially addressed only mild criticism toward the Yugoslav leadership, ${ }^{327}$ the PCI quickly reasserted the myth of Soviet infallibility. ${ }^{328}$ It strongly criticized the violence and terror of the Yugoslav regime in its de-Italianization of the Istrian region and, emphasizing Italian governmental subservience to the imperative of pro-Titoist US foreign policy, presented the FTT as the only feasible solution to preserve Italian culture and language on the Eastern border. ${ }^{329}$

Meanwhile, national and local political governing elites responded to the Tito-Stalin rift by showing increasing apprehension for the future of Trieste and opposed Yugoslav propaganda by encouraging any initiative which promoted the Italian identity of the territory. For example, undersecretary of state, Christian Democrat Giulio Andreotti, approved an appropriation of 2,000,000 lire for the building of the local Church in S. Saba in order to strengthen "Italianità" of a neighborhood that was "mainly populated by Slavs." 330 In addition, the Italian government financially supported the wide network of pro-Italian local lay and religious associations. ${ }^{331}$ Rome's distribution of financial support to these local associations depended on the opinions of the Office

\footnotetext{
${ }^{324}$ Ugo Stile, "I retroscena della crisi," Il Corriere della Sera (June 30, 1948).

${ }^{325}$ Millo (2011), 77.

${ }^{326}$ FBIS (July, 1948).

${ }^{327}$ Marco Galeazzi, “Appunti sulle relazioni tra i comunisti italiani, francesi, e jugoslavi,” in Nazione, interdipendenza e integrazione: le relazioni internazionali dell'Italia (1917-1989) Volume II, ed. Federico Romero and Antonio Varsori (Roma: Carocci Editore, 2005), 59.

${ }^{328}$ Pietro Secchia, "L'Unione Sovietica forza dirigente nella lotta per il socialismo," L'Unità (June 30, 1948).

${ }^{329}$ Karlsen, 229.

${ }^{330}$ UZC, Sez. II, Fondo Trieste, Fasc. "Padri Servi di Maria-Trieste," Busta 27.

${ }^{331}$ The Italian government perceived with rising distrust Yugoslav openness to the West and highly criticized secret Yugoslav-US negotiations on military furniture. FBIS (October-November, 1948).
} 
of Border Zones (UZC) whose decisions were influenced more by the local representative of the national government, the zonal President Gino Palutan, rather than by the "Giunta d'Intesa" (Junta). ${ }^{332}$

In late 1948, for example, Palutan suggested that the UZC grant financial support to the National League in order to re-orient the upcoming electoral campaign in strong national terms and strengthen the cohesion of the Italian bloc. ${ }^{333}$ These decisions were motivated by the necessity to respond to local criticisms of perceived governmental apathy toward the fate of the Italian lands beyond Trieste. ${ }^{334}$ As a response, the central government arranged a set of public initiatives that aimed to portray the border as indisputably Italian, among them the September 1948 exhibition "Trieste Italiana" (Italian Trieste). ${ }^{335}$

More importantly, the Italian government viewed the activities of right extremist political groups in positive terms, which ultimately poisoned the relationship between political elites in Rome and Trieste. In December 1948, the Italian representative in Trieste sent a note to the UZC to dismiss alarms from the local "Giunta d'Intesa" after minor incidents that followed the clash between Italian nationalists and Slav communists. The Italian representative portrayed local national extremists as defenders of "Italianità" and, opposing any intervention from the Allied local police, proposed instead to reward their efforts by providing a "job, preferably in Italian territory. $" 336$

Moreover, in such a climate of connivance between central institutions and far-right political movements, the Ministry of Interior also established a special branch named "Ufficio Affari Riservati” (The Office of Confidential Affairs, UAR). Pre-existing governmental offices which had dealt with confidential general affairs and special information merged into this new governmental office. Mainly consisting of members of the fascist political police (Organization for Vigilance and

\footnotetext{
${ }^{332}$ Millo (2011), 92.

${ }^{333}$ UZC, Sez, II, Fondo Trieste, "Consulta d'intesa dei circoli italiani," December 1, 1948, Fasc. 43 174, Busta 3, Vol. I.

334،"Il giornalismo politico dinnanzi al problema giuliano" Difesa Adriatica (August 19, 1948).

${ }^{335}$ Hametz (2005), 164.

${ }^{336}$ UZC, Sez.II, Fondo Trieste, "Riservatissima, attività gruppi facinorosi a Trieste,” December 1, 1948, Fasc. 43 152, Busta 28, 12/3.
} 
Repression of Anti-Fascism, OVRA), its aim was to collect information for security and public order. This complex network, which was very active in Trieste, monitored communist activity, cooperated with the US secret service, and provided significant support for rightist subversive forces. ${ }^{337}$

In summary, throughout the first few months of 1948, the Tripartite Declaration boosted Italian confidence for a favorable solution of the Triestine problem; however, the Tito-Stalin rift drastically changed the American attitudes toward the Yugoslav regime. Tito, previously considered a threat, now became a potential ally and the US administration perceived the border dispute as a potential obstacle to contain Soviet communism. American statesman Adlai Stevenson, later appointed as U.S. ambassador to the U.N., well summarized the new orientations of the US administration toward the Trieste question by referring to the renunciation of sovereignty over zone $\mathrm{B}$ as reasonable price for Italian entrance into the $\mathrm{UN} .{ }^{338}$ Italian national interests were now irreconcilable with the major international goals of the American administration yet the Italian government, conscious of its possible political costs, opposed any renunciation of earlier claims to Trieste and its territory.

\section{9-1952: Diplomacy at Work}

By 1949, the FTT had become "a needless source of tension between two countries the United States considered important" and the American and British position strongly supported a solution that favored a direct compromise between the Italian and Yugoslav governments. ${ }^{339}$ The reincorporation of the city and its territory within Italian state borders, however, was met with broad popular consensus inside and outside Trieste. The local administrative elections of 1949, which resulted in the victory of the Italian bloc under the leadership of Gianni Bartoli, the local leader of the Christian Democrats and future head of the local Committee for the Defense of the "Italianità"

\footnotetext{
${ }^{337}$ Giacomo Pacini, Il Cuore occulto del potere (Roma: Nutrimenti, 2010), 19-51.

${ }^{338}$ See Giorgio Cesare, “L'azione del CLN dell'Istria e il problema dell'esodo,” ed. Delbello and Spazzali, 93.

${ }^{339}$ Rabel, 131.
} 
of Trieste and Istria, confirmed the strength of support for a pro-Italian solution to the Triestine problem. ${ }^{340}$ In commenting on the electoral results of 1949, pro-governmental press rhetorically depicted it as proof of the "imperishable rights of Trieste's essential Italian character." ${ }^{341}$ The communist press, for its part, praised the success of the local PCI, the second strongest political party of the city, and emphasized the significant defeat of the Titoist front. ${ }^{342}$ The local PCI also emphasized the fictitious existence of pro and anti-Italian factions inside Trieste and presented the popular vote as a significant backlash to the anti-national and anti-communist campaign promoted by both local and national Christian Democrats. ${ }^{343}$

Whereas the pro-governmental and communist press continued to read Trieste's reality through the lenses of Cold War's ideology, the Independence Front adopted a more pragmatic approach that highlighted the constant anxiety and hardship of the city and its territory. In his article of June 19, 1949, Fabio Cusin argued that the Italian state's unresponsiveness to the economic and political crisis in Triestine society, and, most importantly, the dangerous resurgence of local Fascism could threaten the "Italianità" of the city. ${ }^{344}$ Consequently, the weakening of the Italian bloc and its "patriottardo" (jingoistic) spirit enabled the pro-Independence Front to become the third largest local political force in Trieste with 18,000 supporters. ${ }^{345}$

The Christian Democratic government, however, misread the impressive rise of the Independence Movement and did not understand that its growth revealed people's increasing disapproval toward the Italian state and its local expressions. Similarly, the US political adviser in Trieste emphasized the local strength of the Communist Party and right extremism. ${ }^{346}$ Neither the Italian government nor the Allies understood the strength of the independence political parties

\footnotetext{
${ }^{340}$ Corrado Belci, "Gianni Bartoli, la vita," in Gianni Bartoli e il suo tempo, ed. Grazia Tatò (Trieste: Deputazione di Storia Patria per la Venezia Giulia, 2011), 13.

${ }^{341}$ FBIS (June 15, 1949).

${ }^{342}$ Giancarlo Pajetta, "Dopo il voto," L’Unità (June 15, 1949).

${ }^{343}$ Gianni Rodari, "Grande affermazione comunista a Trieste," L’Unità (June 14, 1949).

${ }^{344}$ Article published in Cervani (1994), 128.

${ }^{345}$ Grassi, 56.

${ }^{346}$ NARA, RG 84 (Fps), Department of State, Italy U.S. Embassy, Rome Classified General Records 1946-1964, US Political Adviser, Trieste "Secret Enclosure Dispatch: Anti-communist and anti-fascist strategy," No.230, July 6, 1949, Box 47.
} 
whose propaganda highlighted the limits of both Italian and Allied economic policies toward Trieste. Indeed, external financial contributions made Trieste a city based upon an artificial and subsidized rather than entrepreneurial market economy whose downsides would clearly emerge after 1954. Meanwhile, the neo-irredentist rhetoric of the Italian government that envisioned the reincorporation of the FTT inside Italy's borders continued to appeal to Triestines who perceived the AMG as the main obstacle to a definitive pro-Italian solution of the Triestine problem. ${ }^{347}$ In contrast, supporters of the Independence Movement restlessly advocated geo-political autonomy for the FTT and used the prolonged and unresolved status of the Triestine problem to locally weaken the image of the Italian state.

In addition, the strengthening of economic and political relations between Yugoslavia and the United States as well as Italian inability to impose modifications to the objectionable clauses of the Paris Peace Treaty in exchange for loyalty to the new Atlantic alliance further exacerbated local criticisms. ${ }^{348}$ To appease local public opinion, the national government argued that, due to the failure to implement the UN resolution to establish the FTT, Italy had maintained its sovereignty over Trieste and its territory. Such a claim was first formulated by the rector of Trieste University, Angelo Cammarata. Later known as the "Cammarata thesis," it was used by a variety of political actors to reassert the indisputable nature of Italian territorial claims over the border. ${ }^{349}$

Likewise, Yugoslav Foreign Minister Edvard Kardelj's declaration that "under no circumstances will Yugoslavia give up an inch of zone B” demonstrated Yugoslav views toward the issue. $^{350}$ These conflicting arguments confirmed the cumbersome nature of the Triestine problem. Thus, when Yugoslav authorities decided to extend national legislation to the occupied zone B and introduce a single currency, political relationships between Rome and Belgrade were strained even further. Moreover, Yugoslav restrictions on people's mobility between the demarcation lines,

\footnotetext{
347،"Il senso della patria,” Difesa Adriatica (April 29, 1950).

${ }^{348}$ Antonio Varsori, "Italy between Atlantic Alliance and EDC, 1948-1955," in Power in Europe? II: Great Britain, France, Germany, and Italy and the Origins of the EEC, 1952-1957, ed. Ennio Di Nolfo (New York: W de $\mathrm{G}, 1992), 263$.

${ }^{349}$ Valdevit (1986), 238.

${ }^{350}$ FBIS (March 2, 1950).
} 
repression of religious practices as well as physical violence against the Italian population of the area accelerated the exodus of the Italian minority. ${ }^{351}$ These discriminatory practices came to international public attention and were labeled by the Manchester Guardian as "the closest to the Nazi procedures." 352 Within Italian public opinion, the zone B was portrayed as the victim of Yugoslav oppression which ultimately aimed to carry out the forced de-Italianization of the region and the effacement of its historical memory. ${ }^{353}$ This anti-Yugoslav campaign implicitly suggested that only the extension of Italian statehood could restore a regime of justice and freedom. ${ }^{354}$ In addition to the main Italian Istrian émigré association, the ANVGD, strongly disillusioned by the weak response of the central government to Yugoslav discrimination, defined the Christian Democrats in Rome as a bunch of "inept, unconscious, and political criminals." ${ }^{355}$ The national governing elites, for their part, were eager to silence these criticisms. Viewing the presence of neo-fascists and nationalists among ANVGD's executive committee as detrimental to bilateral relations between Rome and Belgrade, the central government decided to interrupt financial support to the organization. This decision was driven by the necessity to prove the absence of any institutional connivance with resurgent neo-fascism, a factor that could weaken Italy's international credibility and adversely affect diplomatic talks over the FTT.

Between 1950 and 1951, indeed, the "Trieste question" became the subject of prolonged negotiations. ${ }^{356}$ Due to the expansion of the Cold War to new parts of the globe, the United States was forced to reformulate its strategy toward the Balkans and alleviate tension between the Adriatic neighbors. Therefore, the American administration, despite the pronounced Atlanticism of Italian foreign policy, actively promoted the accession of Greece and Turkey into NATO and signed a

\footnotetext{
${ }^{351}$ Ballinger has pointed out that Yugoslav search for control of the Northern Adriatic by means of restrictions on fishing, transportation, and tourism was an integral part of Tito's state-building process. See Ballinger, "La frantumazione dello spazio adriatico," ed. Cocco and Minardi, 30.

${ }^{352}$ FBIS (April 20, 1950).

353“"Vandalismi a Capodistria," Il Pensiero Mazziniano ( March 10, 1950).

${ }^{354}$ Il Pensiero Mazziniano (December 12, 1950).

${ }^{355}$ UZC, Fondo Comitati e Associazioni, May 2, 1950, Busta 14, 59/1.

${ }^{356}$ De Castro defines this time period as the dynamic phase of the Trieste question. Allied openness to hypothesis of both revision of the peace treaty's clauses and a plebiscite in the FTT mistakenly boosted the confidence of the Italian diplomacy for a favorable resolution of the Triestine problem. See De Castro (1981), Volume II.
} 
mutual security agreement with Tito's Yugoslavia in 1951. As The New York Times noted, the American administration had "to hold the reins of a team of horses that start pulling in opposite directions. ${ }^{, 357}$

In particular, Secretary of State Dean Acheson, while defining Soviet accusations of U.S. responsibility for the failure of the FTT as "nonsense," also firmly dismissed Italian arguments regarding the Tripartite Declaration which judged it as "a pledge even if it was not such." Indeed, Acheson clearly stated that direct bilateral talks between Italy and Yugoslavia remained the best means to find a positive solution to the "Trieste question," a position that clearly revealed the untenable nature of Italian hopes to extend Italian territorial sovereignty over the entire FTT. ${ }^{358}$

The Italian government, therefore, operating in an unfavorable international political context, embraced a new aggressive strategy. First, it strengthened Italian propaganda in zone B. ${ }^{359}$ Second, it irresponsibly contributed to an anti-Allied campaign that portrayed the AMG as the main obstacle to Trieste's return to Italy. ${ }^{360}$ Finally, it showed greater complacency toward local right extremism. ${ }^{361}$ In so doing, the Italian government attributed an uncompromising political and ideological meaning to the defense of Trieste's Italian identity.

Concurrently, Italian authorities in Trieste increasingly feared the aggressive tone of Yugoslav policies and the popular success of the Independence Front, which was now perceived as the main threat to Trieste's "Italianità." ${ }^{362}$ Trieste's Prefect portrayed the movement for the FTT as "poison" that, increasingly supported by both white Yugoslavs and unhappy Italians, was even more dangerous than local communism. ${ }^{363}$ To cope with the threat of the growing Independence

\footnotetext{
357،"Tug of War in Trieste," The New York Times (April 8, 1950).

${ }^{358}$ NARA, RG 59 Records of the Office of Western European Affairs, 1941-1954 Subject Files, 1950 “Acheson response to Soviet note," April 22, 1950, Box 9.

${ }^{359}$ UZC, Sez. II, Fondo Trieste, Fasc. 4.3.328, " Memorandum assistenza straordinaria alla zona B (C.L.N.)," December 2, 1950, Busta 55, Vol. I, 19/1.

${ }^{360}$ Spazzali (2011), 12.

${ }^{361}$ Millo (2011), 87.

${ }^{362}$ UZC, Sez. II, Fondo Trieste, Fasc. 43 384, "Comitato Coordinamento Politico," January 22, 1951, Busta 75, Vol. I, $23 / 5$.

${ }^{363}$ The Independence Front was mainly fragmented among the "Fronte dell'Indipendenza," the "Blocco Triestino," and the "Unione Democratica Slovena," all supporters of an independent political solution to the Triestine problem and
} 
Movement, the Prefect suggested the central government to strengthen Italian propaganda and present any communist or anti-Italian solution as an open threat to the moral and territorial integrity of the nation itself. ${ }^{364}$

In writing the central government, the National League also accentuated the threat of the pro-Independence Movement. The association, while explaining the rising success of the Independent Front in terms of "the lack of action of governmental political parties to unmask its anti-national strategy," requested the creation of a central pro-Italian newspaper to back its alleged apolitical activity. ${ }^{365}$ To respond to these requests and cope with the rising demands of the incoming émigrés, the national government established a special fund for Trieste whose impressive resources also gradually became the subject of political speculation and controversy between the local Italian authorities and political groups of nationalist inspiration. ${ }^{366}$

While responding to the pressure coming from local institutions and neo-irredentist associations, the central government continued to view the identity of the city and its territory in purely national terms. It proved unable to understand the significant legacy of concurrent Italian cultural identity and autonomous economic ambitions, and mistakenly perceived the rise of proindependence sentiment as the cause instead of the consequence of the weakening of local patriotic sentiments after years of Allied occupation. Above all, it failed to fully understand people's disillusionment toward the central government, which had been unable to uphold the promises of territorial reunification and economic prosperity.

Throughout 1951, the central Italian government, hoping to further undermine the legitimacy of the Allied authorities in Trieste, also showed an increasingly benevolent attitude toward political extremist movements. ${ }^{367}$ For example, the Italian representative in Trieste

differently expressing strong Italian or Slovene group identities. Despite the presence of multiple newspapers, more or less financially supported by Belgrade, the main voice of political independence remained Il Corriere di Trieste.

${ }^{364}$ UZC, Sezione II, Fondo Trieste, Fasc. 43 384, "Comitato Coordinamento Politico," February 1, 1951, Busta 75, Vol. I, 23/5.

${ }^{365}$ UZC, Sezione II, Fondo Trieste, “Trieste Elezioni Comunali,” June 12, 1951, Fasc 43 256/1, Busta 39, Vol. II 15/2.

${ }^{366}$ ACS, Ministero Interno, Fasc.Permanenti, Prefetture-Prefetti 1944-1966, Fasc. 85/F, Trieste, B.5.

${ }^{367}$ Millo (2011), 54. 
confirmed to the central government that the bomb attacks of February and September against both the AMG and the Independence Front had been likely carried out by right extremists; however, only in November and following the discovery of illegal weapons and munitions did the local police proceed to arrest a few well-known local extremists, a delay that was hardly justifiable. ${ }^{368}$ In addition and by means of local propaganda and the press, central authorities underscored rightist views of the newly appointed head of the AMG, General John Winterton, as an intransigent antiItalian. ${ }^{369}$ The leader of the Independence Movement, Fabio Cusin had predicted this gradual change in Roman politics and denounced the dangerous connivance between neo-fascism and local politicians. Their subservience to Roman politicians and their machinations, he argued, threatened to place the future of Trieste on the past paths of Fiume and other Istrian cities. ${ }^{370}$

In a context of rising local political extremism, Prime Minister De Gasperi travelled to Washington in September 1951 and made his final attempt to win American support for Trieste's return to Italy by predicting that a significant decline in the US presence of the Adriatic border would lead to a further weakening of the Western front against the communist threat. De Gasperi also emphasized that Italy would never accept further territorial losses yet his arguments were overshadowed by the crucial strategic role of Tito's regime in any future European conflict with the Soviet Union. ${ }^{371}$ The positive status of American and Yugoslav relations, indeed, made the partition of the Triestine border inevitable. As a result of these diplomatic developments, the Italian community of the zone B and its associations became increasingly disillusioned about a future possible return of the territory to Italian sovereignty. ${ }^{372}$

Meanwhile, the Yugoslav government, aware of its privileged position, hoped to debunk the irredentist claims of the Italian government and disprove its accusations that it had forcibly removed

\footnotetext{
${ }^{368}$ UZC, Sez. II, Fondo Trieste, Missione Italiana Trieste, “Sequestro di armi e munizioni,” November 8, 1951 , Busta 4.

${ }^{369}$ Millo (2011), 101.

${ }^{370}$ Article published in Cervani (1994), 262.

${ }^{371}$ W.H. Lawrence, "De Gasperi Urges Congress to Back Italians on Trieste,” The New York Times (September 25, 1951).

${ }^{372}$ ACS, Partiti Politici, Schedario, 1944-1966, Divisione Affari Riservati, 1951-1953, Cat.O10 (Jugoslavia), B.33.
} 
the Italian minority from the Istrian region. ${ }^{373}$ With the support of Yugoslav agents who proved particularly active in Trieste and the Julian region, the Yugoslav authorities planned mass demonstrations in Trieste. ${ }^{374}$ To respond to Yugoslav propaganda, neo-fascist groups under the leadership of Marshall Rodolfo Graziani, former fascist Governor of Italian colonies in Africa and Commander in Chief of the Italian Army during WWII, organized counter-demonstrations in Trieste and established patriotic committees against foreign occupation and for national independence. Connected to the most radical segments of the Salò Republic and also partially supported by the Communist Party, these groups were strongly divided and played only a marginal role in subsequent events; ${ }^{375}$ however, their presence further confirmed the existence of dangerous political right-wing extremist movements in Trieste.

As discussed so far, between 1949 and 1952 the "Trieste question" remained unresolved and the unsatisfactory results of the diplomatic talks strengthened feelings of frustration, pessimism, and apathy among significant segments of the Italian community in Trieste. The central government, stressing the bloody nature of Tito's dictatorship, attempted to mobilize lay, religious, and political organizations to advance national Italian interests on the eastern border. In addition, the governmental coalition still naively believed it had a privileged relationship with the Western Allies and, while rejecting any alternative solution, continued to assert the value of the Tripartite Declaration.

The failure of diplomatic negotiations, however, strengthened the pro-Independence Front and its popular attractiveness as well as the anti-governmental campaign of both communist and neo-fascist movements. The national government, unable to assert Italian rule over the Triestine territory, experienced its first local electoral setback in the administrative elections of 1949 which

\footnotetext{
${ }^{373}$ ACS, Partiti Politici, Schedario, 1944-1966, Divisione Affari Riservati, 1951-1953, Cat.O10 (Jugoslavia), "Folder Jugoslavia situazione politica ed economica," B.33.

${ }^{374}$ ACS,Partiti Politici, Schedario, 1944-1966, Divisione Affari Riservati, 1951-1953, Cat.O10 (Jugoslavia), "Folder attività jugoslave in Italia," January-May 1952, B. 33.

${ }^{375}$ ACS, Partiti Politici, Schedario, 1944-1966, Divisione Affari Riservati, 1951-1953, Cat.Z, "Folder rapporti tra PCI e MSI," SIFAR December 18,1950, B.94.
} 
witnessed the rise of both extremist parties of the left and right and the Independence Front. In this context, the Christian Democratic government, striving to extend Italian involvement in the administration of the zone A and increasingly frustrated by Western openness to Tito, gradually embraced the nationalist rhetoric animating significant fringes of both local and national public opinion and also proved willing to support any local anti-Yugoslav movement. Apprehension and fear for the fate of the Julian city combined with Rome's awareness of the unbearable political costs of "losing" Trieste. Facing the celebration of the fourth anniversary of the Tripartite Declaration and the popular vote in the upcoming local administrative elections, the Italian government was tempted to flirt with the Italian radical right.

\section{On the Path to Territorial Partition: Political, Social, and Military Tension across the Border}

Over time, Allied proposals for a resolution that was based upon territorial modifications, shared control or popular plebiscite clashed with the irreconcilable positions of both the Italian and Yugoslav states. In particular, the Italian public's nervousness over the diplomatic deadlock on Trieste was aggravated by rising distrust toward the pro-Yugoslav attitudes of the Allies. Thus, the Italian government and its local representatives, fearing the loss of popular support among nationalist fringes of national public opinion, acted with increasing political firmness.

First, to consolidate the Italian presence in zone A, the national government exercised political pressure on the Allied administration and requested the establishment of a specific office in Trieste, that of the Italian Political Advisor. Second, the UZC financially supported the local committee for the defense of the "Italianità" of Trieste and Istria, which was led by Mayor Bartoli and locally coordinated the activities of pro-Italian political parties and associations that mobilized to reassert Italian territorial claims over the FTT. In March of the fourth anniversary of the Tripartite Declaration, the committee requested that the AMG authorize a mass celebration. Despite its refusal, on March 20 and 21, 1952, Triestines gathered in "Piazza Unità" (Unity Square) to demand the implementation of the Allied declaration and expressed popular opposition to Allied 
rule, chanting "get out of Italy! get out, foreigner!" ${ }^{376}$ In the meantime, right wing extremists, profiting from widespread local hostility toward the Allies, fomented local disorders as well as skirmishes between the local population and the Allied authorities, all of which resulted in 21 wounded and 64 arrests. $^{377}$

The Triestine demonstrations were enthusiastically celebrated by the émigré press as spontaneous expressions of patriotic pride. ${ }^{378}$ Similarly, pro-governmental press, while depicting the demonstrations as a proof of the unbreakable physical and emotional unity of the Istrian region and Trieste, also highlighted the brutality of the civil police which operated under the AMG. ${ }^{379}$ Interestingly enough, the communist press also emphasized the occupiers' repressive and unnecessary violence against the local population yet explained it as a consequence of De Gasperi's long-term subservience to the American ally. ${ }^{380}$ Indeed, it argued, the central government's rhetoric about the application of the Tripartite Declaration was motivated by pure electoral interests and the central government had already agreed to the definitive partition of the city and its territory. ${ }^{381}$ In the United States The New York Times, partially reinforcing the idea of a territorial partition, judged the Triestine events as a "genuine explosion of national feeling" which further emphasized Italian attachment to Trieste, a city metaphorically depicted as a "volcano ready to explode at any time.",382 These arguments highlighted that socio-political anxiety was increasingly growing inside Trieste and its uncontrolled escalation could produce unpredictable consequences. After labeling the Tripartite Declaration as an "election stunt," American journalist Alexander Werth also claimed the existence of "a deep and genuine Italian national feeling" toward Trieste and the territory of the zone B. Due to its rooted Italian identity, according to Werth, Trieste was a new "Fiume" within Italian public discourse and only a plebiscite could peacefully settle the problem. However, Tito's

\footnotetext{
${ }^{376}$ ACS, MI, Partiti Politici, Schedario, 1944-1966, Divisione Affari Riservati, 1951-1953, Cat.O10 (Jugoslavia), B.36.

${ }^{377}$ Millo (2011), 112-116.

378،“Tutto il popolo italiano ha impugnato la fiaccola della riscossa triestina," Difesa Adriatica (March 29, 1952).

${ }^{379}$ Pasquale Ritucci “Trieste,” Il Pensiero Mazziniano (April 10, 1952).

380 "Sdegnata protesta alla Camera contro le violenze degli alleati a Trieste," L'Unità (March 22, 1952).

381 "Rinuncia all'italianità di Trieste nelle manovre degli atlantici e della DC,' L'Unità (March 27, 1952).

382 "The Trieste Volcano," The New York Times (March 28, 1952).
} 
uncompromising attitude and America's friendly stance toward Yugoslavia had made such a solution unfeasible and fomented anti-British and anti-American feelings from below. Such sentiment, in Werth's opinion, combined with spreading disillusionment toward the national government in Rome and seriously threatened the young Italian democracy. ${ }^{383}$ Likewise, the Independence Movement in Trieste publicly accused the central government of complacency towards right-wing movements. In particular, it repeatedly claimed that the central government as well as segments of both local and national public opinion was searching for a martyr to justify the opposition to the AMG and legitimize the city's return to Italy. ${ }^{384}$

Above all, the 1952 riots clearly revealed the necessity to break the long diplomatic impasse. Although the national government leaned toward movements of nationalist inspiration, it financially supported only local movements whose views publicly aligned to those of the Christian Democrats. ${ }^{385}$ Indeed, it refused to support the initiative of the ANVGD, which it viewed as easily subjected to the political influence of local extremist fringes. ${ }^{386}$ Although the national government proved willing to sharpen the tones of the political campaign against the Allies, De Gasperi's leadership and its strong inclination toward European and Atlantic loyalty helped temporarily contain the spread of radical extremism.

It was in such a tense socio-political context that the AMG, anticipating the local administrative elections, eventually approved the expansion of Italian administration to zone A in May $1952 .^{387}$ The pro-governmental press celebrated the Italian involvement in the administration of Trieste as a preliminary step to the fulfillment of the Tripartite Declaration without any prejudice to Italian claims over zone B. ${ }^{388}$ The communist press, by contrast, highlighted Rome's betrayal of the Italians living on the border, in particular the Istrians of zone B. Whereas five years earlier

\footnotetext{
${ }^{383}$ Alexander Werth, “The Trieste Boomerang," The Nation (April 19, 1952).

${ }^{384}$ Grassi, 82.

${ }^{385}$ UZC, Sez. II, Fondo Trieste, “Circolo Cavana di Trieste,” April 17, 1952, Fasc. T 138, Busta 33, Vol. I.

${ }^{386}$ UZC, Fondo Comitati e Associazioni, "Letter from Palutan to PCM," June 9, 1952, Busta 11, Vol. I.

${ }^{387}$ NARA, RG 263 Records of the Central Intelligence Agency, “Report on 1952, Trieste,” Box 76.

388، Solo i cominformisti negano il valore di un accordo giudicato a Belgrado eccessivamente favorevole all'Italia," $L a$ Voce Repubblicana (May 11, 1952).
} 
Italians in Istria had been portrayed as fascists and ostracized by the same press, they were now portrayed as sacrificial victims of higher Western strategic interests. ${ }^{389}$

It is interesting to note that the language and content of both the leftist and rightist press against the national government and its subservience to Allied occupation showed some unexpected convergences. Arguments presenting the reassertion of Italian territorial sovereignty as a gradient of the state's ability to defend the Eastern border's "Italianità" became central to political propaganda against the central government. Meanwhile, the Independence Front, supporting the FTT as the only option to preserve the multi-cultural and multi-linguistic identity of the region, presented the diplomatic talks that were taking place in London between Italian, British, and American diplomats as the platform to finalize the shameful barter: Trieste to Italy and the zone B to Yugoslavia. ${ }^{390}$

The Christian Democrats lost about 7,000 votes in the late May administrative elections as compared to those of 1949. At the same time, local support for the neo-Fascist party increased and especially the Independence Front doubled its previous results, achieving 27,000 popular votes. ${ }^{391}$ The political success of the Independence Front confirmed that people in Trieste did not simply turn to solutions offered by local and national neo-fascist formations, but they also embraced the policies and goals of groups calling for home rule. Together with Yugoslav plans to remove the Italian presence from the area under its administration, growing support for the Independence Movement further weakened the image of the Italian state on the border. ${ }^{392}$ In July Rome appointed Diego De Castro $^{393}$ as Italian political adviser to the Allied government in Trieste, without Anglo-American

\footnotetext{
389، Conferma ufficiosa alle trattative per la spartizione del TL di Trieste," L'Unità (August 25, 1952).

390، 'La conferenza di Londra sta per terminare con l'insuccesso politico e propagandistico," Il Corriere di Trieste (May $8,1952)$.

${ }^{391}$ Vezzà and Comelli, 63.

${ }^{392}$ The Italian clergy became the main target of Yugoslav policies whose anti-Italian propaganda underscored the equation of the concept of fascist and people's enemy with specific emphasis on Italian middle-class and pro-Moscow communists. UZC, Sez, II, Fondo Trieste, Secret Telegram, "Situazione in zona B," May 24, 1952, Busta 39, Vol. I.

${ }^{393}$ Millo (2011) provides an accurate analysis of the figure of De Castro, a former member of the secret service under the Italian Southern Government and established academic of Istrian origins with significant expertise on the region. The antagonistic relations between De Castro and the local prefect Vitelli best symbolized the strained relations between local and central authorities pursuing opposing strategies that aimed to compromise or sabotage Allied actions in order to advance Italian claims over the border. De Castro also attempted to mediate between communist leader Vidali and members of the Independence Front in favor of a solution based upon the unification of both zones under the UN administration; however, the plan was strongly opposed by the central authorities in Rome.
} 
approval. ${ }^{394}$ De Castro's goal was to ease the transition from the AMG to the Italian administration in zone A and resolve the Triestine problem. ${ }^{395}$ Despite De Castro's appointment, confidential reports from Trieste emphasized that the local Italian population proved increasingly frustrated by the prolonged diplomatic negotiations over the Triestine territory and its animosity toward the Allied authorities further soured. ${ }^{396}$

In the meantime, De Gasperi, aiming to reassert the Italian sovereignty over the cities located on the Istrian shore from Trieste to Umago and fearing an electoral backlash, refused a final advantageous American proposal for the recognition of Yugoslav sovereignty over zone B in exchange for Capodistria, Isola, and Pirano. ${ }^{397}$ Such a choice, also motivated by the prospective and definitive loss of about half of the Italian population living in zone B, ended any realistic Italian ambitions to regain control over part of Istria. Despite this, diplomatic negotiations between the Italian and Yugoslav governments continued; their opposing positions, however, were hardly reconcilable. Meanwhile disillusionment and concern toward the fate of Trieste mounted within Italian national public opinion in light of the "New Look" of the Eisenhower administration. ${ }^{398}$

This "New Look" postulated a twofold strategy that aimed to strengthen the relationship between Yugoslavia, Turkey, and Greece on the one hand and induce the involvement of Yugoslavia in NATO on the other, potentially creating a buffer against the Soviets in southeastern Europe. ${ }^{399}$ Talks regarding the withdrawal of the Allied troops from the area were met with the favor of the British government, yet the American administration showed increasing concern for the potential defection of the Italian government from the Atlantic Pact and refusal to ratify the treaty

\footnotetext{
${ }^{394}$ Office of Current Intelligence, Central Intelligence Agency, OCI No.6442, July 17, 1952.

${ }^{395}$ Bogdan Novak, Trieste 1941-1954 (Chicago: University Press, 1970), 371.

${ }^{396}$ ACS, Partiti Politici, Schedario, 1944-1966, Divisione Affari Riservati, 1951-1953, (cat.O10), Folder servizi informativi jugoslavi in Italia, January 28, 1953, B.36.

${ }^{397}$ Diego Gon, "Il Problema di Trieste 1945-1954," Osservatorio Strategico (7) (July, 2004): 43.

${ }^{398}$ Giampaolo Valdevit, Trieste 1953-1954. L'ultima crisi? (Trieste: OTE Spa, 1994), 25.

${ }^{399}$ This new trend in US foreign policy also affected the views of the Christian Democrats who gradually turned away from Atlanticism to strengthen European unity. See Simona Colarizi, "The Italian Political Parties and Foreign Policy in the 1950s: DC, PSI, PCI, MSI,” ed. Di Nolfo, 384.
} 
establishing the European Defense Community, a development that would further weaken NATO's southern front. ${ }^{400}$

Consequently, Trieste increasingly became a "sore spot" which also interfered with the unfolding of the Ankara Pact pursued by the Eisenhower administration to militarily tie Yugoslavia, Greece, and Turkey. ${ }^{401}$ A report of the National Security Council confirmed the necessity to resolve the Triestine question by bilateral talks and maintain Tito's regime outside the Soviet sphere. By increasing military and economic aid to Tito, it was expected that the Yugoslav attitude toward the Western world would improve and, in the long-term, also soften Tito's communist dictatorship. ${ }^{402}$ Thus, by 1953 American political interests in the Adriatic proved irreconcilable with Italy's orthodox defense of its territorial claims over the Triestine territory. Consequently, right-wing political extremist groups in and outside Trieste used the conflicting Italian and Allied interests to locally fuel anti-American sentiments among the Italian population.

In its campaign, nationalist groups not only attacked the Allied government for its opposition to a pro-Italian solution of the Triestine problem, but they also highlighted Allied support for the local Independence Front. In such a political climate, right-wing extremists increasingly targeted any political formations advocating a non-Italian solution to the border dispute. On March 8, 1953, indeed, following an electoral speech, neo-fascists detonated a bomb at the headquarters of the Independence Movement in Trieste. Members of the local neo-Fascist party (MSI) later revealed to the Italian intelligence service that during the demonstrations of March 8 the planned bombing had been initially suspended due to the presence of police officers, yet the bomb had been mishandled and accidentally exploded. In addition, foreseeing possible incidents on the occasion of the approaching fifth anniversary of the Tripartite Declaration, the Italian political adviser in Trieste reported to the central government that "the Allied authorities requested the Italian police to closely control the protesters coming to Trieste.” De Castro also guaranteed to the

\footnotetext{
${ }^{400}$ Varsori, ed. Romero and Varsori, 173.

${ }^{401}$ Valdevit (1999), 166.

${ }^{402}$ NARA, RG 59 Subject Files Relating to National Security Policy 1950-1957, NSC study of US foreign policy toward Yugoslavia 1953, Box 59.
} 
Allies that he would talk with student organizations and extremist right groups before the demonstration in order to moderate the protest against the AMG; however, "the local head of the M.S.I. only controlled 1,000 out of 10,000 members of the movement.” In particular, De Castro concluded, "after March 8, the Allies changed strategy... and now fear that local tension could escalate into a bloody confrontation between the local police and right-wing agitators. ${ }^{, 403}$ As this report suggests, not only the AMG was concerned about local political urban violence but also both Roman and Triestine authorities were aware of the plans of political extremist groups. ${ }^{404}$

The importance of the March 8 bombing incident, however, was minimized by the Allied authorities who intended to forestall Yugoslav criticisms, debilitate neo-fascist propaganda, and hide from the public any former relationship with right-wing extremists. Among some members of the Italian government, this decision fostered the idea of Allied impotence toward subversive actions. ${ }^{405}$ Thus, the central authorities increasingly perceived local right-wing groups as a political resource to mobilize against both the AMG and the Independence Front. American intelligence, however, continued to look with suspicion to local neo-fascist formations and increasingly saw the zone A of the FTT as a ramp used by Moscow agents to penetrate into Yugoslavia and undermine Tito's government. $^{406}$

Anticipating the summer national elections, De Gasperi made a last desperate attempt to tie the ratification of the European Defense Community project to the resolution of the Trieste question. ${ }^{407}$ This political move was received negatively by the US administration which, was mainly concerned about the gradual rapprochement between Yugoslavia and the Soviet Union following the death of Stalin and the problematic end of the Korean War. The 1953 electoral defeat of the coalition led by De Gasperi revealed the weakness of the centrist parties and the growing

\footnotetext{
${ }^{403}$ UZC, Sez.II, Fondo Trieste, “Secret Reports,” March 11-14, 1953, Busta 4.

${ }^{404}$ After the incidents which also fomented urban skirmishes between protesters and police, two people were acquitted, two fined, and another fourteen sentenced to 6 to 9 months in jail.

${ }^{405}$ Millo (2011), 137.

${ }^{406}$ NARA, RG 263, Records of the Central Intelligence Agency, Report of May 1953, Box 76.

${ }^{407}$ Varsori, ed. Di Nolfo, 278.
} 
influence of the Italian Communist Party, both of which persuaded the United States to accelerate the resolution of the Triestine problem. ${ }^{408}$

Meanwhile, the new Italian government led by Christian Democrat Giuseppe Pella hoped to quickly resolve the Triestine question and decided to flex its muscles in the confrontation with the Yugoslav neighbor. This decision, aiming to reaffirm Italian claims to sovereignty over the border and defy the local Independence Movement, marked Trieste's last immediate postwar crisis. ${ }^{409}$ The increasing popularity of the Independence Movement and the repressive nature of Yugoslav policies in zone B weakened the image of the Italian state inside and outside Trieste. ${ }^{410}$ In this context, mutually uncompromising attitudes led Italy and Yugoslavia to the brink of a military confrontation. $^{411}$

In response to Tito's threatened annexation of zone B, the Italian government strengthened the security of the border by providing military and financial support to about 6000 members in anti-communist and anti-Slav partisan formations. ${ }^{412}$ In August 1953, it also mobilized the Italian Army (Delta Operation) with the substantial acquiescence of both the American and British governments. L'Unitá, labeling Prime Minister Pella as a clown, highlighted the dangerous illusions of past and present expressions of nationalism, which could again bring down the Italian state in a vortex of violence and war. ${ }^{413}$

\footnotetext{
${ }^{408}$ NARA, RG 84 Records of the Foreign Service Posts of the Department of State Italy Rome Embassy Records of Clara Boothe Luce 1955-1957, "Memorandum of conversation De Gasperi-Luce," June 22, 1953, Box 1.

${ }^{409}$ UZC, Sezione IV Zone di Confine all'Ufficio Regioni (Trieste e provincia), "Movimento indipendentista filoitaliano: corrispondenza De Castro-Zoppi," August 21-August 26, 1953, Fasc. T. 584, Busta 19.

${ }^{410}$ De Castro reported in great detail the case of Riccardo Coslovich who, affiliated to the British intelligence service, suffered significant physical violence and was secluded by the Yugoslav authorities. UZC, Sez.II, Fondo Jugosalvia e Varie, Fasc. 4 148, "Processo a carico di italiani celebrato a Capodistria," July 15, 1953, Busta 17.

${ }^{411}$ After months of psychological and political attrition, Italian political elites responded to rumors of Tito's annexationist ambitions. The military maneuvers of the Yugoslav Army between Slovenia and Croatia were countered by Italian troops in Operation Delta. Negative Allied attitudes and the prospective of imponderable escalation, however, persuaded the Italian government to abandon any plan to reincorporate zone B and to focus its attention on Trieste. After the bipartite note of October 1953, the presence of troops around Trieste was intended to work as a means of persuasion toward the Allies yet on November 9 both Italian and Yugoslav troops were definitively withdrawn. See George Meyr, "L’Opzione Militare: le Forze Armate Italiane nella Crisi dell'Estate-Autunno 1953," in Dalla cortina di ferro al confine ponte: a cinquant'anni dal Memorandum di Londra, l'allargamento della NATO e dell'Unione Europea, ed. George Meyr e Raoul Pupo (Trieste: Edizioni Comune di Trieste, 2008), 38-43.

${ }^{412}$ Taviani (2002), 406.

413“"Pagliacciate pericolose," L'Unitá (September 5, 1953).
} 
In his personal diary, Paolo Emilio Taviani, Minister of Defense at that time, drew attention to the danger of losing Trieste in case of Italian unresponsiveness to Yugoslav rising economic, cultural, political, and military penetration, which he later referred to as "Balkanization." ${ }^{414}$ Taviani stated that Tito in early September, aware of the clear Italian majority of the FTT and determined not to sacrifice Slovene access to the Adriatic, had refused to settle the issue by means of a popular plebiscite. The Italian government, aware of the marginal geo-political and economic value of the zone B and concerned about new possible national elections, refused any solution that implied the loss of Italian sovereignty. ${ }^{415}$ In view of the risk of Trieste's Balkanization, the Italian establishment embraced the idea that "time works against us" and pursued the immediate return of Trieste, while postponing the settlement of the zone B. ${ }^{416}$

Center-left Triestine politicians, regardless of the strong adventurist pronouncements and actions of the Pella's government, still openly embraced the concept of broad autonomy for the entire territory of Trieste. This solution slightly differed from that of the Tripartite Declaration and had been already promoted by the Julian autonomist movement four years earlier. ${ }^{417}$ This option was supported by local political figures such as socialist Bruno Pincherle, with his ties to wartime lay and social democratic resistance movements, and symbolized the survival of autonomous strivings within parts of the Triestine community that ultimately influenced local politics after $1954 .^{418}$

Nevertheless, large segments of the Triestine community envisioned the restoration of Italian political and territorial control over Trieste first and the entire FTT later. In her account of those "hot" days, Clare Boothe Luce, U.S. Ambassador to Italy and one of the main proponents of an Italian resolution of the Trieste question, reported her concern to the Secretary of State, John Foster Dulles. She predicted a possible wave of anti-Western and anti-American attitudes among

\footnotetext{
${ }^{414}$ Taviani, 14.

${ }^{415}$ ACS, MI, Divisione Affari Riservati, 1951-1953, Folder TLT, Notizie politiche, "Reaction to Tito's Speech," September 8,1953, B.73.

${ }^{416}$ Taviani, 35.

${ }^{417}$ UZC, Sez.II, Fondo Trieste, “Secret Reports," September 5, 1953, Busta 4.

${ }^{418}$ Verrocchio, 104.
} 
the Italian population which was strongly disillusioned by the Allied policy in Trieste. Pella confirmed to Luce that Trieste represented a key to his Atlantic and Europeanist foreign policy, yet his government needed to settle the problem at least in the spirit of the Tripartite Declaration. Even though a plebiscite remained the most favorable option, Pella's government was willing to accept a provisional solution to better prepare national public opinion for a future definitive resolution. Italian Minister of Defense Paolo Taviani also confirmed to Luce the necessity to avoid a definitive solution which no Italian government would be able to survive and made clear that "once Trieste was returned, the highly emotional state would subside since most of Italians had no idea where Capodistria or Pirano were located." 419 These conversations revealed that the Italian government, concerned with the risks of a possible "Balkanization" and aware of the unbearable political consequences coming from the formal sacrifice of zone B, proved willing to suspend informally its claim to sovereignty over that part of territory which that had been lost since 1947 , if it now made possible Trieste's return.

In addition, Luce, fearing possible incidents in Trieste to justify the intervention of Italian troops in zone A, urged both Secretary of State John Foster Dulles and President Eisenhower to quickly implement the partition of zone A and B of the FTT, which also met with the acquiescence of Pella and his government. ${ }^{420}$ To urge the Eisenhower administration to finally resolve the Trieste question, Luce wrote to the President's Special Assistant, Charles Douglas Jackson, "if the President doesn't settle Trieste in the next few weeks, he may lose his next Congress." ${ }^{, 21}$

In her personal memoirs of September 1953, Luce emphasized the continuity between Pella and De Gasperi's foreign policy and expressed confidence in Italian understanding of the futility of any military attempt to modify the status of zone A. She also recorded Tito's personal assurance of

\footnotetext{
${ }^{419}$ NARA, RG 84 (Fsp), Department of State Italy Rome Embassy Records of Clara Boothe Luce 1953-1955, "Trieste Vol. I, Action Plan, Top Secret," August 29 to September, 1953, Box 1.

${ }^{420}$ NARA, RG 84 (Fsp), Department of State Italy Rome Embassy Records of Clara Boothe Luce 1953-1955, Trieste Vol. I, Action Plan, Top Secret, “Luce's letter top secret information to Dulles and Eisenhower," September 5, 1953, Box 1.

${ }^{421}$ NARA, RG 84 (Fsp), Department of State Italy Rome Embassy Records of Clara Boothe Luce 1953-1955, Trieste Vol. I, Action Plan, Top Secret, "Luce letter to Special Assistant of the President," September 7, 1953, Box 1.
} 
Yugoslav unwillingness to go to war over Trieste yet showed concern for an irresponsible Italian attempt to connect the Triestine problem to important issues of Western security. On September 28, Pella's requests for a plebiscite in zone B after the Italian annexation of zone A, which were unacceptable to Belgrade, convinced Luce of the need to secretly pursue a three-power agreement to work out a reasonable compromise. ${ }^{422}$ A few days before this meeting, after being informed of the withdrawal of Italian troops from the border, Luce clearly stated to the British Ambassador to Italy Victor Mallet that "within the agenda of the conference a plebiscite should not be an option." 423

On October 8, 1953 the American and British governments made a common declaration, also known as the Bi-Partite Declaration that proclaimed their willingness to transfer sovereignty of zone A to Italy. ${ }^{424}$ This announcement was anticipated by secret communications in which the Anglo-Americans confirmed the definitive partition of the zones A and B to Tito. ${ }^{425}$ In the meantime, they also stated the partition's temporary status to Pella. ${ }^{426}$ Despite this reassurance and because of the pressure by the Slovenes, Tito firmly rejected the perspective of an immediate restoration of Italian rule in the city of Trieste and rhetorically threatened the use of force if Italian troops entered zone A.

As discussed above, the Italian government gradually increased its political influence inside Trieste by establishing the figure of the Italian Political Advisor and holding local administrative elections. Due to the prolonged failure of diplomatic negotiations, the local Italian political front witnessed a gradual decline in popular support to the advantage of the Independence Movement. Meanwhile, the AMG, locally perceived as the main obstacle to Trieste's return to Italian sovereignty, became the target of local political extremists whose actions and anti-Allied

\footnotetext{
${ }^{422}$ Library of Congress (LC), Clara Boothe Luce, "Memories," Conversations with Pella September 1953, Box 315.

${ }^{423}$ LC, Clara Boothe Luce, “Ambassador to Italy, 1953-1961,” September 25, 1953, Box 600.

${ }^{424}$ Valdevit (1994), 25.

${ }^{425}$ NARA, RG 84 (Fsp), Department of State Italy Rome Embassy Records of Clara Boothe Luce 1953-1955, Trieste Vol. I, Action Plan, Top Secret, Telegram from Dulles to Tito on October 6, 1953, Box 1.

${ }^{426}$ NARA, RG 84 (Fsp), Department of State Italy Rome Embassy Records of Clara Boothe Luce 1953-1955, Trieste Vol. I, Action Plan, Top Secret, "Meeting Luce and Pella," Telegram October 7, 1953, Box 1.
} 
propaganda met the acquiescence of the Italian central authorities. The American administration, coping with increasing popular hostility inside Trieste and fearing a possible rapprochement between Tito and the post-Stalinist Soviet Union, decided to accelerate the resolution of the Triestine problem. As a response, the new Italian government led by Christian Democrat Giuseppe Pella turned to a more aggressive strategy. Further promoting public anxiety for the "Balkanization" of Trieste, the Pella government escalated political and military tension with the Yugoslav neighbor. American pressure, however, helped defuse the threat of military conflict. In response to the American administration's firm determination to settle the issue, both the Italian and Yugoslav governments accepted the October Bi-Partite Declaration.

\section{Rallying around the Flag: Dying for Trieste November 1953}

In October 1953 Italian public opinion celebrated the American and British Bi-Partite Declaration with cheerful expressions and mass demonstrations. Popular enthusiasm, however, was only partially echoed within the pages of pro-governmental press. Its temperate response contrasted with the joy and confidence with which it had welcomed the Tripartite Declaration five years earlier and emphasized both Trieste's joy and sorrow for a decision that was clearly aimed toward a possible partition. ${ }^{427}$ The communist press, especially, stressed that legitimate Italian interests in the zone B were now fatally threatened by the imminent partition and political weakness of the Italian government. $^{428}$

Above all, both the nationalist and communist press highlighted the inability of the Christian Democrats to reassert national sovereignty over the disputed border. In contrast, external observers such as The New York Times warmly welcomed the Bi-Partite declaration as the final diplomatic step to resolving the crisis; however, fears of resurgent nationalist violence and widespread concern for the foolishness of a possible localized war did not disappear. The American newspaper

\footnotetext{
427،"Piú alto il sipario di ferro fra Trieste e la zona B," La Voce Repubblicana (October 11, 1953).

${ }^{428}$ "Pella scarta tutte le vie atte a salvare la zona B e l'integrità del TL di Trieste," L'Unità (October 18, 1953).
} 
condemned both Tito for his careless accusations against the Allies and the Italian government's “equally pugnacious mood.",429

Entangled between Allied pressure and the necessity to uphold the image of a firm defense of Italian claims over the disputed border, the central government also feared the detrimental role that acts of local political violence could play on the prospected partition. Indeed, the Italian Minister of Interior, Christian Democrat Amintore Fanfani, invited local authorities to carefully monitor the activity around Allied diplomatic missions, requesting that they allow a mass jubilee demonstration in Trieste yet repress any excessive outburst that could endanger the government's position. $^{430}$

Consequently, intelligence reports about the massive infiltration of Titoist agents in Trieste only exacerbated the apprehension of the central government which feared an uncontrolled escalation of political violence in the city. ${ }^{431}$ These concerns were further aggravated by the reports of the Triestine Prefect Giuseppe Vitelli to the central government. According to Vitelli, both "Radio Trieste" and "Trieste Libera," two Italian-language radio stations under Yugoslav control, were spreading misinformation and inciting local antagonism against the $\mathrm{AMG} .{ }^{432} \mathrm{In}$ addition, secret telegrams from the Udine Prefect reported that the Independence Front planned demonstrations to oppose the AMG orders and create incidents that could later be blamed on the Italian front. ${ }^{433}$ The independence front press especially warned the public of possible Yugoslav military plans to occupy Trieste, ultimately increasing socio-political anxiety inside the city. ${ }^{434}$ As these reports suggest, the Independence Front, supported by the Yugoslav government, purposefully

\footnotetext{
429"'Madness Over Trieste," The New York Times (October 12, 1953).

${ }^{430}$ ACS, MI, Gabinetto 1953-1956, "Manifestazione Italianità Trieste," Fasc. 1737/1, October 8, 1953, B.71.

${ }^{431}$ ACS, MI, Divisione Affari Riservati, 1951-1953, Cat.C., Folder cittadini jugoslavi in Italia, "SIFAR Note," October 8, 1953, B.30.

${ }^{432}$ UZC, Fondo Jugoslavia e Varie, Fasc. 459 Emittente Radiofonica della Amministrazione Militare Jugoslava, April 2-October 17, 1953, B.4

${ }^{433}$ ACS, MI, Divisione Affari Riservati, 1951-1953, Folder TLT, Notizie Politiche, "Secret Report from Udine’s Prefect," October 17, 1953, B.73.

434،"Gli anglo-americani tradiscono il mandato delle Nazioni Unite,” Il Corriere di Trieste (October 9, 1953).
} 
raised tension inside Trieste and provoked a violent clash between opposing Italian and Slovene nationalist factions which could ultimately hold back the prospected partition. ${ }^{435}$

At the same time, the Italian Army Information Service discovered the preparation of acts of sabotage and smuggling of weapons inside the FTT by members of the Italian extreme right. In addition, extremist groups planned mass demonstrations both inside and outside Trieste to prove popular opposition to any renunciation of Italian sovereignty over the city and its territory. ${ }^{436}$ The Italian government, however, proved more concerned for a possible coup by pro-Tito forces. ${ }^{437}$ This threat, further aggravated by rumors about a possible American military disengagement from Trieste, ${ }^{438}$ was used by the Italian government to justify to the Allies the transport of weapons to Trieste with the goal of arming and training pro-Italian military formations. ${ }^{439}$ In late October Prefect Vitelli also confirmed that the Committee for the Defense of the Italianess of Trieste and Istria and Christian Democrat Mayor Gianni Bartoli agreed to orchestrate a series of acts of sabotage against Slav propaganda. ${ }^{440}$ Under the leadership of former chief of police and Army General Giovanni D’Antoni, all Italian parties except the local communists, agreed to take action against Titoist armed groups and participate in a mass demonstration of Trieste's "Italianità" on November $4 .^{441}$ As a result, tensions between the local Allied authorities, in particular General Winterton, and the Italian government in Rome increased exponentially.

At the same time, Prime Minister Pella insisted that a conference be held after Trieste's formal annexation and the entrance of Italian troops into zone A. Minister of Defense Paolo Taviani explained to American Ambassador Luce that, even though the Italian national government was

\footnotetext{
${ }^{435}$ ACS, MI, Divisione Affari Riservati, 1951-1953, Folder TLT, “Confidential Note to Ministrer Pavone,” October 19, 1953, B.73.

${ }^{436}$ UZC, Sez. II, Fondo Trieste, "Riservato," October 7, 1953, Busta 92, Vol II.

${ }^{437}$ The Italian information service reported the existence of a strong Titoist network that under the camouflage of cultural, economic, and commercial organizations intensively operated in Trieste and was also supported by the Yugoslav military mission in Bari and former elements of the Garibaldi formations; however, other reports stressed low Yugoslav popular antagonism toward Italy over the Trieste question and widespread popular unwillingness to enter an armed conflict. ACS, Partiti Politici, Schedario, 1944-1966, Divisione Affari Riservati, 1951-1953, Cat.O10 (Jugoslavia), Folder Jugoslavia situazione politica, Report of October 5,1953, B.28.

${ }^{438}$ ACS, MI, Divisione Affari Riservati, 1951-1953, Folder TLT, Notizie Politiche, "Secret Note to General Mesco," October 11, 1953, B.73.

${ }^{439}$ Millo (2011), 156.

${ }^{440}$ UZC, Sez.II, Fondo Trieste, Riservatissima, "Situazione a Trieste,” October 23, 1953, Busta 92, Vol II.

${ }^{441}$ UZC, Sez.II, Fondo Trieste, Riservata, "Questione triestina-relazione," October 30, 1953, Busta 92, Vol II.
} 
aware of the fact that Yugoslav troops in zone B had been gradually withdrawn, it needed a significant success in foreign policy for the upcoming elections. ${ }^{442}$ On October 29 , Secretary of the Italian Christian Democratic Party De Gasperi also addressed the political rather than territorial nature of the problem, making it clear that "no Italian government can renounce zone B forever." However, he added that an Italian government could guarantee "to never resort to arms in connection with any dispute about zone B." ${ }^{443}$ These remarks demonstrated the general willingness of the Italian government to publicly accept the partition of the FTT as long as it allowed the government to present it as a temporary solution which would then appear to be an outstanding victory in foreign policy.

The concurrent mobilization of local pro-Italian groups inside Trieste and the desperate search for a diplomatic success by the Italian government were symptomatic of its mounting political adventurism and were promptly exploited by the communist press to denigrate the central state authorities. ${ }^{444}$ In the diplomatic conversations during the days anticipating the celebrations of November 4, the thirty-fifth anniversary of Trieste's liberation from Austria-Hungary, state officials repeatedly referred to the danger of possible explosions of localized political violence. ${ }^{445}$ In one of such instances, on November 3, Italian Ambassador Alberto Tarchiani met with American Secretary of State Dulles to discuss the Triestine problem. During the conversation, Tarchiani, based upon the previous American failure to uphold the Tripartite Declaration, doubted U.S. commitment to the October 8 declaration and subtly mentioned a "possible civil takeover which might not include the introduction of Italian troops.” Dulles harshly criticized the attitude and tones of the Italian government, which he believed, made the implementation of the October decision problematic. Dulles firmly warned the Italian representative about the necessity to resolve the problem according

\footnotetext{
${ }^{442}$ NARA, RG 84 (Fsp), Department of State Italy Rome Embassy Records of Clara Boothe Luce 1953-1955, October 8- October 16, Trieste Volume 4, Top Secret, Telegram October 13, 1953, Box 1.

${ }^{443}$ NARA, RG 84 (Fsp), Department of State Italy Rome Embassy Records of Clara Boothe Luce 1953-1955, October 8- October 16, Trieste Volume 4, Top Secret, Memorandum of Conversation between Henry Luce, Alcide De Gasperi, and John McCloy, October 29,1953, Box 1.

444"Vana istanza dell'Ambasciatore Tarchiani per ottenere lo sgombero della Zona A," L'Unità (November 4, 1953).

${ }^{445}$ NARA, RG 84 (Fsp), Department of State Italy Rome Embassy Records of Clara Boothe Luce 1953-1955,

"Memorandum of conversation between Henry Luce, Alcide De Gasperi, and John McCloy," October 29, 1953 , Box 1.
} 
to US wishes rather than "Italian alleged credit of confidence toward the US." 446 This conversation highlighted American negative views towards the Italian government's reckless strategy over Trieste and perhaps played a crucial role in containing the violent riots of the following days.

Anticipating the celebrations of November 4, the local and national press conducted a new campaign of vilification against the Allied administration in Trieste, which was often portrayed as the instrument of the pro-Independence Movement. ${ }^{447}$ In particular, the pro-governmental press, while celebrating the memories and sacrifices of the Great War, advocated a local common patriotic effort at the local level to oppose foreign occupation and assert "Italian self-determination." 448 In the peak of hostility against the AMG, Trieste celebrated its expected return to Italy with unruly expressions of enthusiasm between November 4 and 6. In the process, violent skirmishes between demonstrators and local police erupted and were brutally suppressed. ${ }^{449}$

In his report on the dynamics of the incidents, Trieste's local police Prefect strongly emphasized that the Allies were responsible for the conflicts. Vitelli reported that on November 3, after the local council's decision to show the Italian flag, the Anglo-American authorities had it removed. The day after, about 200 people responded to the Allied decision through mass protest and their repeated efforts to demonstrate their opinions were strongly suppressed throughout the entire day. On November 5, the protest of about 1,000 students outside the Sant'Antonio Church was again violently suppressed by the police whose shooting caused two deaths and resulted in street fighting that lasted until night. Finally on November 6, the repressive police actions resulted in four other deaths and the protesters responded by means of bombs and shootings until order was finally restored by Allied forces. The accidents, in which 6 people died, 83 were wounded, 39

\footnotetext{
${ }^{446}$ NARA, RG 84 (Fsp), Department of State Italy Rome Embassy Records of Clara Boothe Luce 1953-1955, October 8- October 16, Trieste Volume 4, Top Secret, "Memorandum of Conversation, Trieste," November 3, 1953 Box 1. ${ }^{447}$ Grassi, 129 .

${ }^{448}$ Santi Savarino, "Trieste nel cuore di tutti gli italiani mentre si esaltano i caduti della grande guerra," Il Giornale d'Italia (November 5, 1953).

${ }^{449}$ Paolo Nello, "La Politica italiana e la questione di Trieste," in Trieste 1945-1954: Un sogno tricolore, ed. Paolo Nello (Firenze: Alinari, 2004), 24.
} 
arrested and 79 policemen were wounded, created a climate of tension, fear, and mutual accusations. $^{450}$

The Prefect's reconstruction of those days, however, has been largely disproved by recent scholarly works that have minimized Allied responsibility and emphasized the planned nature of the riots. Anna Millo has convincingly shown that on November 3, Mayor Gianni Bartoli's decision to install the Italian flag at the top of the local council building had purposefully contradicted Winterton's directives, ultimately causing the clash between Anglo-American authorities and the crowd that gathered in the main square on November 4. Furthermore, on the morning of November 5 , new riots broke out between protesters, mainly young students, and civil police in response to police orders to disband. Some protesters, located between San Giusto Church and the police headquarters, looked for shelter inside the Church yet the police violently broke in and arrested them. In particular, during the afternoon re-consecration of Sant'Antonio Church, civil police responded to the throwing of rocks by shooting; however, it is now clear that the shots which killed two people did not come from the local police. On November 6, the Italian front under the leadership of the Committee for the Defense of the Italianità of Trieste and Istria arranged a mass protest in the main city square, which hosted both the local council and the palace of the government, in order to protest against the repressive police actions of the previous day. Violence again erupted in the exchange between protesters and civil police and resulted in four other deaths. Despite the highly inflated number of 20,000 people provided from the AMG government, participants in the popular rioting were not more than 3,000 and only a few hundred were actively involved in the events that resulted in 6 deaths and 167 wounded during those days. ${ }^{451}$

Documents of the Office of Border Zones (UZC) have further confirmed this interpretation and the existence of armed squads in Trieste that were only partially disbanded after the anti-Allied

\footnotetext{
${ }^{450}$ ACS, MI, Gabinetto 1953-1956, Manifestazione Italianità Trieste, "Phonograms on accidents,” November 5-9, 1953, Fasc. 1737/6, B.71.

${ }^{451}$ Millo (2011), 165.
} 
demonstrations. ${ }^{452}$ In particular, in commenting on Winterton's decision to ban the Italian flag from the local council building, a report of the UZC stated that since Trieste had already been virtually given back to Italy, Allied orders to postpone symbolic displays of the transfer of power could only foment possible incidents that someone "expected and wished." 453 Although the report did not clearly state who or which institution would have actually benefited from the rioting against the Allied authority, the involvement of significant personalities of the Pella's government is hardly disputable. Indeed De Castro, a few days after the Triestine events and while informing General Secretary of Italian Foreign Affairs Vittorio Zoppi of the November riots, stressed that foreign diplomacy firmly believed in a theory of Italian governmental complicity with right extremism to accelerate the passage of powers in Trieste. Such an interpretation, defined as "idiotic" by De Castro, was instead supported by the presence of local neo-fascist extremists who, also known as the Cavana squads and connected to the most intransigent anti-communist fringes of the central government were present in the crowd outside the Church and the assault in Unity Square. ${ }^{454}$ Although De Castro attempted to dismiss such an interpretation, he later admitted to having been unable to navigate the obdurate positions of those days and that he had been aware of the intricate connection between national political elites, intelligence services, and right extremists as well as their subversive plan to foment the uncontrollable escalation of violence in Trieste. ${ }^{455}$ Thus, in an attempt to reduce tensions with the Allied administration and remove any evidence of its complicity in the Triestine riots, the Italian government enabled the escape of local agitators who had been involved in the riots. ${ }^{456}$

When considering the agreement on the territorial partition of the FTT, the widespread antiAllied rhetoric, Italy's eagerness to refuse any direct responsibility for the loss of the zone B, the

\footnotetext{
${ }^{452}$ ACS, MI, Divisione Affari Riservati, 1957-1960, B.101, Folder Lega Dalmata, "Report,” December 14, 1954.

${ }^{453}$ UZC, Sez.II, Folder Jugoslavia e Varie, Fasc 4164 "Esposizione della bandiera nazionale nelle zone di confine celebrazione della ricorrenza del 4 Novembre," Note of November 1, 1953, Busta 18.

${ }^{454}$ UZC, Sez.II, Trieste, "Secret Letter from De Castro to Zoppi," November 10, 1953, Busta 92, Vol II.

${ }^{455}$ Millo (2011), 159-160.

${ }^{456}$ UZC, Sezione IV Zone di Confine all'Ufficio Regioni (Trieste e provincia), "Cittadini triestini perseguitati dalle autorità di polizia del GMA rifugiatisi in territorio della Repubblica: richiesta di assistenza," November 18, 1953 to February 20, 1954, Fasc. 581 2, Busta 19.
} 
diplomatic talks of early November, and the mild persecution of well-known local extremists, the Italian government's responsibility for the violence in Trieste in early November is clear. ${ }^{457}$ In a revival of past nationalism and aiming to accelerate Trieste's return to Italian administration, the central government used both secret services and neo-fascist squads to compensate for its diplomatic weakness and used the riots to make clear the inadequacy of the AMG to guarantee local order and stability. Its mischievous behavior, strongly motivated by political opportunism and prospected electoral gains, led to the deaths of those days.

On November 7, Triestines responded to Allied violent suppression of the local demonstrations by invoking a mass strike and on November 8 nearly the entire city attended the funeral of the "Triestine martyrs." The commemoration of the victims was used by the central government to reinforce local as well as national sentiments of collective identity and "as a source of group empowerment, as a vehicle for reclaiming the past and as a means of readdressing past injustices. ${ }^{\text {458 }}$ Most important, views of the Pella government on the Triestine incidents mirrored the attitudes and orientations of significant segments of both local and national public opinion, whose feelings of outrage for Allied violence were vividly expressed in the following days by popular demonstrations. ${ }^{459}$ Supporters of Italian rule of Trieste and its territory, especially, stressed Allied responsibility. ${ }^{460}$ The Independence Movement, for its part, highlighted the role of secret political circles and the existence of a long-term plan to foment local tension. ${ }^{461}$ This interpretation

\footnotetext{
${ }^{457}$ This interpretation finds further evidence in Grassi’s work. This author discusses the memories of Mr.Petruzzi, an Italian policeman employed by the Julian Police during the Allied administration. Petruzzi confirmed the Allied awareness of pre-ordered nature of the local disorders, acknowledged the existence of military formations to oppose Titoist forces, and confirmed the broad support for the Independentce Front among members of the AMG. In particular, Petruzzi revealed that preparations outside the Church began a few days earlier to provide the necessary rocks to create disorder and Italian elements inside the police, exploiting local disorders, should have facilitated a takeover of the local "Questura" by local Italian political extremists. Grassi, 114-118.

${ }^{458}$ See B. Misztal, “The Sacralization of Memory,” European Journal of Social Theory 7 (1) (7) (2004): 67-84.

${ }^{459}$ Mass anti-British manifestations crossed the nation. In Genoa, for example, 5000 students manifested solidarity for Trieste and the protest was accompanied by burning of British flags, riots with police as well as fights among neofascist and communist factions.

460“"Basta sangue italiano a Trieste," La Voce Repubblicana ( November 8, 1953).

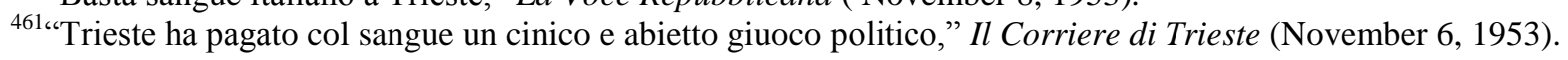


was partially reinforced by the communist press, which highlighted the responsibility of both the Italian and Allied authorities. ${ }^{462}$

Within public discourse, however, the events of 1953 made Trieste a "lovely victim" of the Cold War. ${ }^{463}$ In particular, "the martyrs of November ' $53 \ldots$ were the necessary preamble... to make possible Trieste's return to Italy." ${ }^{464}$ Such an interpretation, loaded with sentimental and rhetorical meanings, crystallized over time and, further underscored by scholarly works, became an integral part of the public memory of the city. ${ }^{465}$ The November incidents, however, perhaps politically accelerated the transfer of power in Trieste, yet only marginally affected the diplomatic process that had already defined Trieste's return to Italy in October 1953.

Despite this, the resonance and significance of the Triestine facts surpassed the local context and, while proving the political value of the instrumental use of the irredentist rhetoric, also revealed the endurance of nationalist understandings of the "Italianità" of the eastern border in postwar Italy. ${ }^{466}$ The narrative of the Triestine riots, indeed, dramatized and sentimentalized the issue of Trieste, symbolically gathering the entire nation around the sorrow and anger of the Julian city. An example of such a process can be found in the open letter that nationalist journalist Alberto Giovannini wrote to American Ambassador Luce. Giovannini harshly criticized the American establishment for its views and attitudes toward the Julian problem that strictly contrasted with Luce's passionate love for Italy. In claiming “we are the creditors, US and Britain our debtors,” Giovannini stressed that the privileging of diplomatic relations with Tito's totalitarian regime had emptied Eisenhower's words of justice for Italy of any meaning. Above all, the image of the Italian Army, "powerless at Trieste's gate, to the spectacle of their allies firing on their fellow citizens," produced popular feelings of enmity toward the Allies among Italians. ${ }^{467}$

\footnotetext{
462"L'Italia dinnanzi ai sanguinosi frutti della politica italiana ," L'Unità (November 6, 1953).

${ }^{463}$ Vidali, 68.

${ }^{464}$ Albertini, 15.

${ }^{465}$ See Piero Delbello, I ragazzi del '53: l'insurrezione di Trieste cinquant'anni dopo (Trieste: Edizioni Italo Svevo, 2003).

${ }^{466}$ See Giuseppe Parlato, Trieste nella politica italiana (1945-1954) (Trieste: Comune di Trieste, 2007).

${ }^{467}$ Alberto Giovannini, “An open letter to Mrs. Clara Luce,” Il Tempo (November 9, 1953).
} 
From an American perspective, however, the incidents were not representative of widespread Italian attitudes toward the Allies, but the outcome of communist and neo-fascist irresponsibility. The New York Times, for instance, praised the effective response of the Allied government during the riots and, echoing its previous editorials on the issue, invited the American administration to finally remove "this powder keg" from Western Europe. ${ }^{468}$ The complexity of the Allied occupation of Trieste and its detrimental effect on the image of the Allies in Italy was vividly exemplified in a report of the American Consulate in Palermo. It recounted sporadic episodes of violence, which were often fomented by small groups of students. These students were reported as having thrown rocks and oranges at the Consulate and delivering offensive notes gently translated and reported as "Englishmen! Bastards you are all sons of __ and __ and Winterton , the brownnoser of the Prince of Edinburgh.” In its account of these demonstrations, the report also emphasized the broad public misinformation that exaggerated the size of these protests, inflating the number of participants from 3,000 to 50,000 and clearly aiming to foster an emotional rather than dispassionate common understanding of the November incidents. ${ }^{469}$

Not all pro-governmental newspapers and magazines in Italy, however, firmly aligned with the prominent criticisms of the Allied powers of those days. Il Pensiero Mazziniano, for example, expressed solidarity for the victims of unjustifiable diplomatic, political, and ideological tensions. It firmly condemned the instrumental manipulation of national patriotism and significantly asked "Italian politics...to not take the same hopeless road to dark nationalism on which the chauvinist attitudes of the Yugoslav dictator are based upon." ${ }^{470}$ Decisively distancing itself from nationalist rhetoric, this journal demonstrated a rare understanding of the events that had revealed the downsides of an uncompromising strategy toward the Adriatic border.

Meanwhile, meeting with Ambassador Luce, De Gasperi stated that the prospective solution of the Trieste question now posed a drastic change for the centrist governmental coalition. In an

\footnotetext{
468"Riots in Italy," The New York Times (November 7, 1953).

${ }^{469}$ NARA, RG 84 (Fsp), Department of State Italy U.S. Embassy, Rome General Records, 1936-1964, American Consulate General Palermo, "Effective Student Demonstration on USIS Palermo," November 9, 1953 , Box 254.

${ }^{470}$ Editor, "Il problema di Trieste," Il Pensiero Mazziniano (November, 1953).
} 
interesting passage De Gasperi added that if the US had given him the October 8 decision before the summer elections, "that would have spared much of what happened since." Such a statement revealed De Gasperi's criticism of Italian recklessness during those days yet does not clarify the role of the old statesman during the most heated phase of the Triestine crisis. ${ }^{471}$

Luce, before Christmas, and probably after this meeting, wrote to Secretary of State Dulles criticizing both Pella's attitude and British diplomacy. Stating "there is nothing the US can do for Italy to prevent the gradual disintegration of the center party and a swing to left or right, if we do not soon settle the matter," she confirmed the impressions provided by De Gasperi. In addition, to support Pella's government and "with it our best chance of getting EDC, facilities, and action against the communists," Luce recommended that the American administration should turn over zone A to Italy and disregard Tito’s reactions “who surely won’t go to war but might turn toward the Soviets." ${ }^{472}$ Meantime, Secretary of State Dulles had indeed threatened to withdraw infrastructural investments from Italy in case of obstruction to the creation of the EDC or opposition to West Germany's involvement in NATO, and clearly stated the foolishness of connecting the Trieste question with Western European security. ${ }^{473}$ Thus, in December, Pella, aware of widespread political opposition to renounce the area from Servola to Muggia and the bay of Zaule, confirmed Italy's commitment to the EDC project and its willingness to participate in a conference based upon the terms of the October Anglo-American Bi-Partite Declaration. ${ }^{474}$ Dulles reacted positively to Pella's statements yet stressed the irresponsible attitude of the Italian leader whose former declarations had resulted in Tito's hostility and negatively affected the implementation of the October agreements. ${ }^{475}$

\footnotetext{
${ }^{471}$ NARA, RG 84 (Fsp), Department of State Italy Rome Embassy Records of Clara Boothe Luce 1953-1955, October 8- October 16, Trieste Volume 4, Top Secret, "Memorandum of Conversation, Luce and De Gasperi," November 26, 1953 Box 1.

${ }^{472}$ LC, Clara Boothe Luce, “Ambassador to Italy , 1953-1956,” Undated, 1953, Box 787.

${ }^{473}$ Valdevit (1994), 50.

${ }^{474}$ NARA, RG 84 Records of the Foreign Service Posts of the Department of State Italy U.S. Embassy, Rome General Records, 1936-1964, "Memorandum of December 24,1953 of MAE,” December 24,1953, Box 254.

${ }^{475}$ NARA, RG 84 Records of the Foreign Service Posts of the Department of State Italy U.S. Embassy, Rome General Records, 1936-1964, "Summary Notes on the Conversation in Paris between M. Foster Dulles and Signor Pella," Paris, December 16,1953, Box 254.
} 
In 1953, when asked "Does it pay to be a communist dictator?” Luce replied "Apparently it pays very well." ${ }^{476}$ Such a statement well exemplified the privileged position of Yugoslav diplomacy vis-a-vis Italian impotence and frustration. Indeed, the Italian government, eager to reaffirm Italian sovereignty of the Adriatic border, had become increasingly alarmed by the proYugoslav views of the American administration. Therefore, fearing national public opinion in case of the definitive loss of the zone B and hoping to accelerate Trieste's return to Italy, it orchestrated an irresponsible anti-Allied campaign which, fed by a subversive network and supported by the UZC, sparked political violence in Trieste. This nationalist outburst, which was accompanied by anti-Allied and anti-Slav hysteria, well reflected the views of leading figures of the Italian government who believed that "our move has been somehow useful, it made the Allies understand that if they stay in Trieste, they will lose both Italy and Yugoslavia." ${ }^{477}$ Instead, it negatively affected American views of Italy, strained political relations between Rome and Trieste, and resulted in an unnecessary spiral of violence which further weakened the low morale of the Italians living in the city of Trieste and its surrounding territory.

\section{Farewell to Istria: the London Memorandum and the End of the "Trieste Question"?}

At the beginning of 1954, following Pella's resignation, Christian Democrat Mario Scelba was appointed by the national Parliament as Prime Minister of Italy. Fearing that any delay in the resolution of the Triestine problem would further jeopardize the terms of the Bi-partite Declaration and Italy would become internationally isolated, the new centrist coalition government undertook a sharp turn in foreign policy and saw national interests best served by the Atlantic relationship. ${ }^{478}$ As a result, the resolution of the border dispute could be no longer postponed and, from the Allied

\footnotetext{
${ }^{476}$ LC, Clara Boothe Luce, “Ambassador to Italy , 1953-1961,” Undated, 1953, Box 635.

${ }^{477}$ Taviani, 79.

${ }^{478}$ Varsori, ed. Di Nolfo, 287.
} 
perspective, the partition of the FTT became the best means to prevent any future threat to Western security coming from southeastern Europe. ${ }^{479}$

Meanwhile, Trieste continued to be a city dominated by fear and insecurity. Arrests of Italians for threats to public security and order exacerbated social tensions. In this context, the recreation of the infamous "Nucleo Mobile" and the acquittal of the Venetian Julian Police Inspector, Ozebek, of judicial charges for the harsh repressive actions of November, further undermined the public's confidence and threatened the outbreak of new incidents. ${ }^{480}$ In addition, the mass exodus from the zone B further reinforced ideas of the harsh nature of Yugoslav rule and was instrumentally used in nationalist propaganda to re-launch the idea of a popular plebiscite for Trieste and its territory. ${ }^{481}$

This option, however, had been long removed from the Allied agenda. To overcome the diplomatic stalemate in direct Italian-Yugoslav negotiations, separate bilateral consultations continued in 1954 between the Anglo-Americans and their Italian and Yugoslav counterparts. Scelba, in his correspondence with Dulles, outlined the problematic connection between the EDC and the Trieste question in national public opinion. He also stated the necessity to carry out no further change to zone A and to mediate with Tito on the problematic issue of Capodistria. ${ }^{482}$ In May, American pressures on Italy to meet Tito's requests for guarantees of Slovene access to the upper Adriatic and to make financial reparations to Yugoslavia for the crimes of Mussolini's regime broke the diplomatic deadlock. ${ }^{483}$

\footnotetext{
${ }^{479}$ General Murras clearly expressed his personal concern for a propsective government decision to cut military funding in 1954. He argued that such a decision would have compromised the security of the border and made hardly possible a mobilization similar to that of summer 1953 in which 800 officers and 13,000 troop soldiers were successfully deployed along the border. British Marshall Bernard Montgomery, however, partially dismissed Italian concerns by making clear that the strengthening of Yugoslav security was complementary to Italian security.

Archivio Stato Maggiore Esercito Italiano (ASME), I-5 SIM 1, Delimitazione Confine Italo-Jugoslavo, Secret, "Sintesi degli argomenti trattati nel corso della riunione dei capi di SS.MM. con il Maresciallo Montgomery," January 30, 1954, Raccoglitore 9.

${ }^{480}$ ACS, MI, Divisione Affari Riservati, 1951-1953, Cat. C, Folder "Relazione sulla situazione politica, economica, dell'ordine e dello spirito pubblico e della sicurezza pubblica," January-February, 1954, B.5.

${ }^{481}$ FBIS (January 14, 1954).

${ }^{482}$ Istituto Don Sturzo (ALS), Fondo Mario Scelba, Busta 20.

${ }^{483}$ Foreign Relations of the United States (FRUS), 1952-1954, Eastern Europe; Soviet Union; Eastern Mediterranean. Vol. VIII, Document 197, May 31,1954.
} 
During the summer, the Italian government formally agreed to a provisional agreement marked by a minimum of written commitments. ${ }^{484}$ This decision was the outcome of three main factors. First, in June, Foreign Minister Gaetano Martino received a Memorandum from Italian officers who reported Ambassador Luce's criticisms of the Italian government and her fear that the country could go communist if the Triestine question was further postponed. ${ }^{485}$ Second, Italian hopes of gaining further concessions on Trieste in exchange for the ratification of the EDC were quickly dashed. ${ }^{486}$ Indeed, following the signature of the Balkan Pact on August 9, 1954 between Greek, Yugoslav, and Turkish representatives, the failure of the EDC project further strengthened the hand of Yugoslav diplomacy. Finally, in mid-September and under American pressure, Tito accepted a minor territorial revision to the Morgan line and agreed to resolve the "Trieste question," which in Eisenhower's mind had become "a needless distraction.",487

Throughout 1954, the Italian government would indeed clearly abandon the goal of regaining the Istrian region, at least in the short-term. Despite this, fringes of the central authorities still harbored nationalist ambitions. For example, the UZC advised the central government to continue its financial support for both the National League and the Popular University and provide an extraordinary yet strictly confidential contribution to these organizations which strongly proclaimed the Italian identity of Trieste and its territory. According to the UZC, it was imperative to uninterruptedly support "the indisputable Italian sentiments of the local administration" which were debased by the pro-Slovene attitudes of the AMG. ${ }^{488}$

In particular, the state authorities needed to avoid further compromise to the credibility of the Italian government by maintaining either the nationalist or communist ownership of the weapons used during the November riots. ${ }^{489}$ The discovery of Western military weapons and munitions in the railway station in Trieste, however, threatened to belie the Italian government's

\footnotetext{
${ }^{484}$ See Raoul Pupo, "L'ultima trattativa per Trieste: la politica italiana," ed. Meyr and Pupo, 25.

${ }^{485}$ Archivio Senato della Repubblica (ASR), Fondo Martino, Busta 6, fasc.2 , "Memorandum," June 9, 1954.

${ }^{486}$ ASR, Fondo Fanfani, Serie II, Attività Politica, Busta 105.

${ }^{487}$ Rebel, 160.

${ }^{488}$ UZC, Sez.II, Fondo Trieste, June 5,1954, Busta 3, Vol.I.

${ }^{489}$ ACS, MI, Divisione Affari Riservati, 1951-1953, Folder Cat.I, “Trieste armi,” August 30, 1954, B.62.
} 
denial of any responsibility for the Triestine incidents. ${ }^{490}$ Rumors of Western ownership of the weapons had already been spread and instrumentally used by the independence press, which wished to prove Italian responsibility for the riots of 1953. Consequently, in a desperate attempt to dismiss these accusations and remove any evidence of its complicity, the Italian government had promised significant benefits to local extremists who refused to cooperate with the Allied authorities during the investigations. ${ }^{491}$ Indeed, although judicial investigations initially blamed the neo-fascist movement, numerous pieces of evidence proved that weapons were sent from Great Britain to Trieste before the incidents of November and were purposefully delivered to the Italian secret services. ${ }^{492}$ In this context, the reckless communications of local patriotic squads created apprehension among central government officials who now attempted to dissociate themselves with any possible connections to past and future threats to Trieste's local order. ${ }^{493}$

While confronting the political aftermath of the Triestine incidents, the Italian government continued to discuss the terms of the territorial agreement with both the Anglo-American representatives. ${ }^{494}$ After months of negotiations, on October 5, 1954, the representatives of the United States and Great Britain signed with the Italian and Yugoslav ambassadors a Memorandum of Understanding in London and the "Trieste question" was apparently settled. ${ }^{495}$ The agreement provided for the withdrawal of the Allied military troops from zone A and its transfer to Italian administration as well as a tiny territorial modification of the border and a shared definition of

\footnotetext{
${ }^{490}$ In December, the local police reported the Presidency of Council the finding of 130 rifles and 64,000 munitions hidden in the Triestine railway station since December 1953. UZC, Sez, II, Trieste, "Riservatissima," December 28, 1954 , Busta 4.

${ }^{491}$ ACS, MI, Divisione Affari Riservati, 1951-1953, Folder Cat.I, “Trieste armi,” November 10,1954, B.62

${ }^{492}$ ACS, MI, Divisione Affari Riservati, 1951-1953, Folder Cat.I Trieste Armi, "Spartaco secret note," September 28, 1954, B.62.

${ }^{493}$ ACS, MI, Divisione Affari Riservati, 1951-1953, Folder passaggio di poteri alle autorità italiane, "Secret note SIFAR," September 14, 1954, B.73.

${ }^{494}$ The Soviets recognized the London Memorandum as part of a broader strategy of détente and rapprochement with Yugoslavia. NARA, RG 59 Subject Files, "Confidential report on Soviet attitude on Trieste settlement," October 29, 1954 , Box 87.

${ }^{495}$ Different scholars have stressed that, over time, the London agreement inevitably led to the Osimo Treaty and the definitive renunciation of any Italian territorial claim to zone B. In particular, the use of the term boundary instead of demarcation line contradicted Italian declarations of the provisional and judicial status established by the Memorandum. The problematic status of the Memorandum within international law was further confirmed by the non- transmission of the agreement to 15 out of 21 of the powers that signed the Paris Peace Treaty. See De Castro, 646.
} 
minority rights by both the Yugoslav and Italian sides. ${ }^{496}$ The Italian surrender of the coast below Punta Sottile, however, resulted in the loss of 27 hamlets and about 3,855 Italians, proving that "Trieste did not help the Istrians, and neither did Rome." ${ }^{497}$ Partially echoing these views, Amintore Fanfani, a leading Christian Democrat politician, recalled in his diary that after years of wasting time and missing more advantageous conditions such as those proposed in September 1951, "we are lucky for what we got now." 498

The Italian government treated the arrangement as provisional in order to avoid the real significance of the London Memorandum with public opinion and to maximize the greatest possible political benefit for the reaffirmation of Italian sovereignty of Trieste. ${ }^{499}$ Indeed, Trieste's return to Italy was accompanied by popular celebrations across the nation. Trieste's reincorporation within national borders was celebrated as "a gift to the indefatigable efforts and indisputable faith in the homeland that virtuously defended the sacrifice of its martyrs." ${ }^{500}$ The Christian Democrat press advertised Scelba's words "time never worked...on our side" to emphasize the importance of a provisional solution that, leaving unchanged Italian territorial claims to zone B, saved the city from the dangers of "Slavization" and prolonged foreign occupation. ${ }^{501}$ The nationalist press praised the nation's solidarity with Istria and focused on the crucial role that the youth's enthusiasm played in the conflict over Trieste. This romanticized depiction portrayed the Triestine youth as the element of continuity with the martyrs of World War One, now recast as the "Good War." ${ }^{502}$ The actions of the Triestine youth made the undisputable "triumph of the nation and its unbreakable will" possible. ${ }^{503}$ The irredentist tones and patriotic rhetoric that marked the narrative of Trieste's return

\footnotetext{
${ }^{496}$ See Map VI.

${ }^{497}$ Petacco, 8.

${ }^{498}$ Archivio Storico del Senato (ASR), Fondo Fanfani, Sezione IV, Diari, October 5, 1954.

${ }^{499}$ Valdevit (1986), 272.

500، Trieste e Salerno," Il Pensiero Mazziniano (October-November, 1954).

${ }^{501}$ Il Popolo broadly covered Trieste's return to Italy by devoting six of its pages to the popular celebration and the political debate that surrounded the event. At the same time, it strongly minimized the reactions of the Julian associations. "Una grande ora per la nostra patria: Trieste all'Italia l'Italia a Trieste," Il Popolo (October 6, 1954). ${ }^{502}$ The First World War, publicly perceived as the good war, was depicted in Trieste as the fourth war of national independence. Taviani argued that the Allies never understood this specificity and were therefore unable to make sense of the uncompromisingly attitude of the national community toward the Triestine problem. See Taviani, 66-67.

${ }^{503}$ Multiple entries on Trieste, Il Giornale d'Italia (October-November, 1954).
} 
Map VI: Italy's Eastern Border after the 1954 London Memorandum

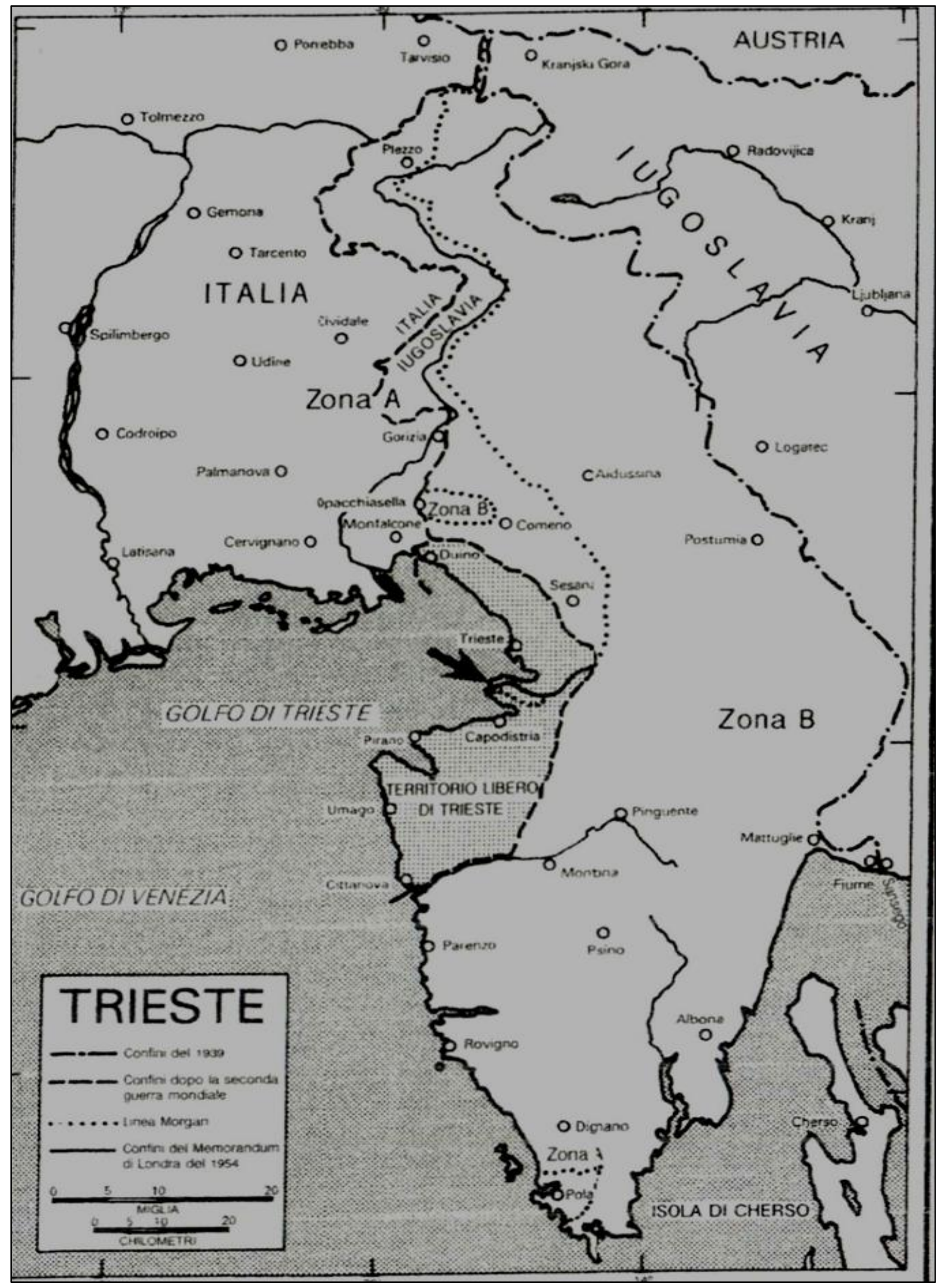


to Italy further confirmed the endurance of nationalist conceptualization of the city's Italian identity. ${ }^{504}$

On October 26, when Italian troops first reentered Trieste, the Triestine newspaper Il Piccolo celebrated the symbolical reunion between soldiers and civilians with photos, patriotic statements, and reiterations of the image of Trieste as the most Risorgimental city. Despite the shrouded reference to the unforgivable breach between Triestines and Istrians and the partial regret for an agreement perceived as unavoidable, the journal vividly expressed hope for Trieste's prosperous future in Italy, ideally portrayed as the "house of liberty and progress." ${ }^{505}$ Partially detaching itself from local and governmental rhetoric, La Voce Repubblicana, the traditional voice of Mazzinian thought, highlighted the presence of mixed feelings of joy and sorrow for the uncertain fate of those "Istrian brothers whom hopes for a future liberation were definitively dashed." ${ }^{506}$ Its criticism of the government's deceitful claims about Istria were strongly echoed by the émigrés press which celebrated the return of Trieste as an expression of residual patriotism, ${ }^{507}$ but argued that pragmatic considerations had fatally undermined local defense of the "natural" borders of the nation which extended beyond Trieste. ${ }^{508}$ These feelings of fear and uncertainty for the fate of the Istrian region were strongly echoed by both the communist and neo-fascist press. The former emphasized the contrast between the local hopes for a bright yet uncertain future, and Tito's confirmation of the definitive nature of the territorial partition. ${ }^{509}$ The latter bluntly celebrated the sacrifices of the Salò Republic for the "Italianissima" region of Istria and blamed the new Republic for its loss. ${ }^{510}$ The neo-fascist movement, which now replaced slogans of the struggle for Trieste with new ones for Istria, celebrated the murder of the Allied commander in Pola in 1947 by former

\footnotetext{
504،"Il testo dell'Accordo," Le Ultime Notizie (October 5, 1954).

505،Una folla incalcolabile acclama i soldati della patria," Il Piccolo (October 26, 1954).

506، Torna il tricolore," La Voce Repubblicana (October 27,1954).

${ }^{507}$ Licio Burlini, "Insegna molte cose l'entusiasmo dei triestini: un'atto fondamentale della recente storia d'Italia," Difesa Adriatica (November 11, 1954).

508“"Quando 1'Italia era tutta irredenta," Difesa Adriatica (November 20, 1954).

${ }^{509}$ Guido Nozzole, "Le truppe italiane sono entrate a Trieste salutate con gioia da tutta la popolazione," L'Unità (October 27,1954) .

${ }^{510}$ Filippo Anfuso, “Oggi l'ennesima rinuncia,” Il Secolo d'Italia (October 5,1954).
} 
fascist Maria Pasquinelli as the supreme embodiment of national sacrifice and an indomitable example of Italianess in the Venetian Julian lands. ${ }^{511}$

Most important, while the national community perceived Trieste's reincorporation as the end of a historical trajectory that resulted in passionate feelings of national unity, the local Istrian population in and outside the zone B experienced Trieste's return as the death of traditional Adriatic irredentist dreams. Trieste's Mayor Bartoli and its Roman Catholic Bishop Santin celebrated the unbroken patriotic faith of the city that had resisted an unbearable peace treaty. They also endorsed the government's proclaimed ambitions for future border revisions which, based upon the ethnic principle, aimed to heal the scars of the imposed agreement. ${ }^{512}$ In journalist Indro Montanelli's words, Santin in particular became the "personification of Trieste, of that mutilated Trieste that went back to the homeland... perhaps the only Italy for which he feels to be an Italian."

Thus the central government, trying to dismiss any direct responsibility for the deaths of the November riots and aware of its rising diplomatic isolation, was compelled to accept the terms of the London agreements. ${ }^{514}$ Trieste's return to Italian sovereignty was accompanied by expressions of national patriotism across the country and formally ended the border dispute with the Yugoslav neighbor. However, its acclaimed provisional status fed the hopes of those Italians who also dreamed of a second "redemption" for the Istrian region.

\section{Cold War Trieste}

After 1945, Trieste, rhetorically depicted as the "unredeemed" city and a bastion of Italian civilization, remained central to post-war conceptualizations of Italy's imagined community. In the context of the Cold War, the Italian government pursued a politics of identity toward the eastern

\footnotetext{
511“"Bersaglieri a Trieste banditi a Capodistria," Il Secolo d'Italia (October 26, 1954).

512،"Le fortune della patria trovano il più sicuro presidio nella difesa degli ideali di indipendenza e di libertà," Il Popolo (November 5, 1954).

${ }^{513}$ Malnati, 330 .

${ }^{514}$ For a full version of the text of the Memorandum of Understanding, see http://freeterritorytrieste.com/TREATIES/UN541005MEMORANDUMLONDRA.pdf
} 
border which ultimately aimed to assert Italian sovereignty over Trieste and its territory. The state's politics was intrinsic of a new ideological meaning which, in the pre-1948 Allied perspective, made Trieste a bulwark against Yugoslav Communism. For nine long years and regardless of American changing policy toward Tito, political leaders of the Italian centrist coalition government read the “Trieste question" through the lenses of modern nationalism. The Italian government used diplomacy, mass mobilization, and covert action to maintain territorial control of Trieste and its territory and gain popular support for the new Republic.

Meanwhile, local and national political movements either supported or opposed Italian sovereignty over Trieste and its territory. Their readings of the Triestine problem either aligned with or diverged from modern nationalist conceptualizations, making also possible the re-emergence of more localized notions of the city's identity which combined with ideas of territorial or administrative autonomy. ${ }^{515}$ Although irredentist views of Trieste's identity were overwhelming within national and local public opinion between 1945 and 1954, the experience of the Independence Movement proved that ideas of Italian identity did not only relate to a set of territorial and cultural propositions but, over time, they also took a more complex political and economic meaning.

The final compromise on Trieste, embodied in the London Memorandum of October 1954, further reduced the territorial extent of the Italian eastern border and assumed a symbolic importance within the changing context of Cold War, which had been marked by gradual Soviet and Yugoslav diplomatic normalization. This compromise also highlighted the weakness of Italian diplomacy and the strength of the Cold War logic. ${ }^{516}$ Most important, the "Trieste question"

\footnotetext{
${ }^{515}$ Not only the independence movement but also segments of the Istrian community proposed an alternative reading of collective identity that significantly diverged from the prisms of ethnicity and nation. It strongly connected to the hybridism of its Mediterranean and Central European borderlands and related to the Habsburg past as an example of tolerance, unity, and Western legacy. See Ashbrook, 871-897.

${ }^{516}$ Massimo de Leonardis, La" diplomazia atlantica" e la soluzione del problema di Trieste (Napoli: Edizioni Scientifiche Italiane, 1992), 511.
} 
magnificently demonstrated that the partition of a disputed territory had a strong impact on the geopolitics, statehood, and identity of the national and, especially, the local community. ${ }^{517}$

Although national and local public opinion celebrated the return of Trieste as "a single and residual expression of that national sentiment which had died on September 8, 1943,"518 the partition of the FTT played a pivotal role in disrupting and reshaping the confidence of the Italian community living along the disputed border toward the reborn Italian state. ${ }^{519}$ Indeed, on November 4, 1954, when Prime Minister Scelba addressed the Triestine crowd, the jubilant atmosphere was punctuated by loud cries of "Istria! Istria!" ${ }^{520}$ At the same time, people in Gorizia were waiting for information on the train coming from Trieste en route to Rome and complained about the unbearable confusion of the train traffic. Some of them lamented, "You can tell that the Italians came." ${ }^{521}$ This anecdote suggests that, despite the strong patriotic rhetoric of those days, people's loyalty toward the Italian state would increasingly depend on the ability of the New Republic to respond their needs. This took specific importance in post-1954 Trieste, an issue that I investigate fully in subsequent chapters.

\footnotetext{
${ }^{517}$ Stefano Bianchini, Partitions: Reshaping States and Minds (New York: Frank Cass, 2005), 163.

${ }^{518}$ Emilio Gentile, La grande Italia, cited in Cattaruzza (2007), 326.

${ }^{519}$ Partitioned areas such as Istria were especially inhabitated by multiple languages and cultural habits that contributed to the reshaping of an identity not in national but in regional terms, fostering the affirmation of "Istrianism" as an alternative to nationalism. Slavenka Drakulic, Cafè Europa: Life After Communism (New York: W.W. Norton \& Company, 1996), 164.

520“"Interrupted by Boos," The New York Times (November 5, 1954).

${ }^{521}$ ASR, Fondo Fanfani, Sezione IV, Diari, November 4, 1954.
} 


\section{Chapter 3}

\section{After London: Re-Thinking Border Politics 1954-1962}

After 1954 and the resolution of the border dispute with the Yugoslav neighbor, the Italian government transformed Trieste's image from a stronghold of "Italianità" into the Western "gate" to the East. Consequentially, the de facto partition of the Adriatic border, which was later formalized in the Osimo Treaty, relegated the issue of what once was zone B to the margins of Cold War politics. The Italian government, therefore, embraced its new European and Atlantic impulses in foreign policy and, in purposing a new and friendly relationship with Tito's Yugoslavia, also inaugurated a season of political relaxation which greatly anticipated Nixon's détente. ${ }^{1}$

Even though the new relationship between Italy and Yugoslavia was oriented toward economic cooperation and social reconciliation between border communities, local ethno-political antagonisms did not disappear from Trieste. ${ }^{2}$ Indeed, the territorial dispute over the Istrian region, which had only been provisionally but not formally settled, provided fertile ground for residual expressions of nationalism and also empowered localized understandings of the border's identity. ${ }^{3}$ In particular, the defense of the integrity of those ethnic pre-war borders stretching to Istria remained significant among fractions of the Julian civil society. For example, local authors such as Pier Antonio Quarantotto Gambini or Biagio Marin, while celebrating Trieste's return to Italy, also criticized the general apathy of the Italian community for the fate of the population living on the border and the gradual minimization of Trieste and Istria to cases of peripheral interest. ${ }^{4}$ Although these views only partially recognized the prolonged efforts of both national and local authorities in defending Italian territorial claims over the Triestine territory, they decisively reinforced a specific

\footnotetext{
${ }^{1}$ Federico Romero, "La scelta atlantica e americana," in Nazione, interdipendenza e integrazione: le relazioni internazionali dell'Italia (1917-1989) Volume I, ed. Federico Romero and Antonio Varsori (Roma: Carocci Editore, 2005), 166.

${ }^{2}$ Jack Raymond, "Italy and Yugoslavia Begin a New Chapter," New York Times (October 10, 1954).

${ }^{3}$ The complex connection between nationalism and localism not as opposing phenomena, rather as complementary and autonomous elements of specific ideas of national identity has only recently became object of scholarly works. For example, in examining the case of Gorizia, Sartori (2012) has brilliantly shown that in border regions, localism and nationalism were embedded within a specific dialectic which reinforced or undermined both elements according to the socio, economic, and political context.

${ }^{4}$ Biagio Marin, "Coscienza nazionale," Trieste (July-August, 1, 1954).
} 
sense of victimization and uniqueness that shaped the attitudes of the local community toward the Italian state.

Throughout this chapter I suggest that after 1954 Italians in both Trieste and the ex-zone B perceived their Italian identity not simply according to notions of territorial sovereignty but rather their understanding of this identity depended on the ability of the new Republic to guarantee security from the communist neighbor, defend formal territorial claims over the ex-zone B, and promote the economic well-being of Trieste. ${ }^{5}$ In making Trieste's economic prosperity the physical representation of post-war achievements of the new Republic and the center of Italian propaganda in the Adriatic, the national government ultimately aimed to reassert Trieste's Italian identity and the city's role as a modern outpost of Western civilization.

\section{The London Memorandum: Definitive or Provisional?}

In 1954, while recognizing the end of one of the most "vexing and dangerous conflicts in Europe," The New York Times also cast doubt on the value of the provisional agreement and portrayed it as a potential source of "future contention." ${ }^{, 6}$ Such an impression, it argued, was confirmed by the far from "wild exultation" that accompanied Trieste's return to Italy. ${ }^{7}$ The American newspaper approached the issue from a pure geo-political perspective and provided a more detached and less romanticized account of the Italian national response to the end of the Triestine problem. ${ }^{8}$

The American newspaper's depiction recognized the reality of an externally-imposed compromise which required the renunciation of former claims by both governments. In 1955,

\footnotetext{
${ }^{5}$ The attempt to renew the traditional maritime trade of the Triestine port and promote a "renaissance" of commercial traffic failed, due to the reduction of ship production, the strong migratory flows from the city, the high cost of imported raw materials, and the wartime decline of the Lloyd maritime company. Trieste's economy remained anchored to the central patronage of the Italian state rather than reintegration inside the European trade market and was unable to achieve economic self-sufficiency.

"“And Now, Trieste!” New York Times (October 5, 1954).

7“"Triestines Cheer Return to Italy as New Accord is Announced," New York Times (October 6, 1954).

${ }^{8}$ Trieste's enthusiasm was not echoed in the response of the main Italian cities to the news of the end of the "Trieste question." See Luigi Vittorio Ferraris, "La Politica estera italiana fra gli anni '60 e gli anni '80," ed. Georg Meyr and Raoul Pupo, 93.
} 
American observers confirmed these impressions and understood that economic pressure had played a crucial role in forcing Tito to accept the London Memorandum; indeed, they predicted that whenever economic and military aid would become less urgent, Italian and Yugoslav relations could degenerate again. ${ }^{9}$

This reading of the London agreements revealed the complexity of its acclaimed and deceitfully provisional nature. ${ }^{10}$ For the next twenty years, the Italian government repeated its claim to territorial sovereignty over the Istrian region. At the same time, however, the central state authorities had to carefully mediate between maintaining the new friendly diplomatic relations with Tito's Yugoslavia and realizing the political and economic promises made to the Triestine and Istrian community. ${ }^{11}$ Therefore, a wide set of unresolved issues remained subjects of prolonged diplomatic negotiations between Rome and Belgrade and also inflamed mutual hostility between Italians and Slovenes along the border. ${ }^{12}$

As discussed in the previous chapter, Allied pressures, political calculations and the necessity to remove the burden of the "Trieste Question" from post-war foreign policy eventually persuaded the Italian government to accept the London agreements. Nevertheless, leading Christian Democratic figures such as Amintore Fanfani, while briefly acting as Prime Minister after Pella's resignation of January 1954, contended that "the separation of the zone A and zone B hurt the Italian national interests" and firmly opposed the idea of the definitive partition of the FTT. ${ }^{13}$ In commenting on the Memorandum, Fanfani stated that it was "unacceptable for the Italian people"

\footnotetext{
${ }^{9}$ FRUS 1955-1957, Volume XXVI, Central and Southeastern Europe, Document 240, April 4, 1955.

${ }^{10}$ Tombesi remembers that, except for the first few moments after De Gasperi's promises to return to the issue, no one believed in the territorial recovery of the Istrian region. In spite of this, local elites only gradually accepted that Italy had indeed lost the war and could hardly improve its position in the Adriatic quarrel.

${ }^{11}$ For an examination of Tito's post-1954 foreign policy see Stefano Pilotto, La politica di non allineamento della Jugoslavia di Tito (Gorizia: Libreria Editrice Goriziana, 2008).

${ }^{12}$ The issue of zone B and its émigrés often became a politicized subject and greatly exemplified the main downsides of the public use of history. Only in 1991, in the attempt to finally historicize the conflict over the Eastern border, the Italian-Slovenian Committee released a final report which examined the birth, rise, and clash between Italian and Slovene opposing nationalisms for the period 1880-1956. Even though it generally showed agreement on highly disputed and tense issues, the divergence between Slovenian views of border violence as an effect casused by fascist rule and Italian emphasis on its nationalist and ethnic nature remained unresolved. See Piero Delbello, " 10 anni per un documento" Tempi \& Cultura 9 (June, 2001): 2-71.

${ }^{13}$ ASR, Sezione I, Attivitá Politica, Serie 1, ss.4, Busta 8, fasc.2, "Confidential Note President of Council Fanfani to Ministry for Defense and Foreign Affairs," January 30, 1954.
} 
and, due to its clear definitive rather than provisional character, invited the Christian Democratic Party to simply approve rather than ratify the agreement. ${ }^{14}$ The national Parliament, indeed, approved the London Memorandum with 295 votes against 265 . $^{15}$ The Communist Party, for its part, opposed the London agreements and organized its local branch inside the former FTT as a separate entity of the PCI. ${ }^{16}$ Right-wing parties also opposed the London Memorandum and continued to demand the re-extension of Italian sovereignty over the ex-zone B. ${ }^{17}$

The reticence of the Italian centrist political parties to accept the border's partition and their rhetoric in support of the Italian community under Yugoslav administration reflected their traditional views toward the Triestine problem and was motivated by unwillingness to accept responsibility for the definitive loss of zone B. In a letter to Fanfani, the local Triestine Christian Democrat Redento Romano vehemently criticized the inability of the national government to obtain any significant concession for the Italians of the ex-zone B, despite granting three cultural centers for the Slovene minority in Trieste. In particular, Romano criticized the statewide party's attitude toward the Triestine representatives who were treated like "little children."18 Similarly, prominent Triestine intellectuals and patriots such as Umberto Saba, Gianni Stuparich, and Ercole Miani signed a common declaration in which they expressed their opposition to an agreement with a totalitarian state that promised to economically suffocate Trieste and create an abyss rather than a bridge between Italians and Yugoslavs. ${ }^{19}$ In supporting the extension of Italian statehood to the

\footnotetext{
${ }^{14}$ Due to the different clauses that not only made any future territorial change impossible but also any guarantee for the Italian minority irrelevant, the secretary of the Christian Democrats, Fanfani, prospected three options: make a simple declaration about the Memorandum, reject the Memorandum after the occupation of zone A and gain freedom of action, or approve it marking its provisional character. Archivio Storico Istituto Luigi Sturzo (ASL), Fondo Democrazia Cristiana, Segreteria Politica, Fanfani, Sc. 59, f.1, "Memorandum,” October 8, 1954.

${ }^{15}$ Leschi, 618.

${ }^{16}$ The PCI established one political representative and trade union for the entire territory, advocated the creation of a free zone for the movement of goods and people, and strengthened socio-political cooperation with the Slovene Communist Party. Archivio Fondazione Istituto Gramsci (AFG), Fondo Vidali, Fascicolo 59, Trieste Il Problema di Trieste e la Lotta Contro la Spartizione del Territorio Libero di Trieste, "Direttive della Direzione PCI," October 29, 1954.

${ }^{17}$ For a detialed study of nationalist propaganda see Istituto Regionale per la Storia del Movimento di Liberazione nel Friuli-Venezia-Giulia (1977), 293-351 and 697-795.

${ }^{18}$ ASL, Fondo Democrazia Cristiana, Segreteria Politica, Fanfani, Sc. 59, f.1, "Romano to Fanfani," October 11, 1954.

${ }^{19}$ Istituto Regionale per la Storia del Movimento di Liberazione Friuli Venezia Giulia (IRSML FVG), Fondo Venezia

Giulia, Busta 31, "Declaration 2357," August 3, 1954.
} 
Istrian region according to ideas of self-determination, these figures once again related to the political and intellectual legacy of Mazzini’s patriotism.

Within national public discourse, however, the Memorandum was generally perceived as an unjust yet necessary compromise. In Trieste, by contrast, any issue related to either the émigrés or the territorial sovereignty of the ex-zone B fostered sporadic expressions of neo-irredentism that detrimentally affected diplomatic relations between the Adriatic neighbors. ${ }^{20}$ In attempting to compensate for its alleged indifference toward Trieste's needs and respond to the criticisms of the neo-fascist movement, the government claimed that every effort would be made to reassert Italian sovereignty over the ex-zone B. ${ }^{21}$ In its pronouncements for public consumption, the central government claimed the Italian residents of zone B as Italian citizens and the southern extension of the former FTT as the ultimate state border between Italy and the Yugoslav Federation. ${ }^{22}$

Despite these rhetorical claims, the Italian state authorities moderated their views of the Yugoslav neighbor and placed greater trust in its relations with the West. Contrary to previous assumptions, a Yugoslav invasion was considered unlikely. According to a secret report prepared by the heads of the Italian Army in the region, General Eugenio De Renzi, Trieste's immediate defense was entrusted to a thousand volunteers and a military brigade of 300 soldiers. This small force, which was considered by De Renzi to be completely inadequate in case of a Yugoslav attack, was expected to resist in such a contingency and support the evacuation of Triestine civilians while morally reasserting Trieste's "Italianità." ${ }^{23}$ Such a strategy confirmed that, contrary to the government's propaganda, the Yugoslav neighbor was hardly perceived as a source of military threat and Trieste's defense had assumed a mere political nature. ${ }^{24}$ Although the London Memorandum partially defused Italian territorial ambitions toward the Istrian region, its intrinsic

\footnotetext{
${ }^{20}$ Archivio on-line Senato, Fondo Cassiano, Busta 11, fasc. 51, "Filippo Anfuso, verso una nuova Yalta," September 22, 1955.

${ }^{21}$ UZC, Sezione II, Fondo Trieste, Busta 31, Folder Territorio Libero di Trieste bilinguità, "Ministro Grazia e Giustizia to PCM," September 29,1956 and Folder fornitura carta d'identità, "CGGTT to PCM," October 12, 1956.

${ }^{22}$ UZC, Sezione II, Fondo Trieste, Busta 3, Vol. II, "Stampa jugoslava-confine jugoslavo su carte geografiche," January 4, 1956.

${ }^{23}$ ASM, Fondo I-5 SIM 1, Raccoglitore 9, Segreto, "De Renzi to National Army’s Commander," December 2, 1956.

24،"Taviani conferma l'efficienza delle difese alle frontiere orientali," Il Piccolo (October 2, 1957).
} 
ambiguity also provided the Italian state an outstanding opportunity to maintain its image mainly yet not solely among the Italians of the Adriatic.

\section{The Return of the Italian State in Trieste: Restoring its Lost Prosperity}

The central government, after rhetorically celebrating the return of the "Italianissima" Trieste, hoped now to strengthen local political consensus and minimize popular concern for the uncertain fate of the zone B. To ease the process of socio-political and economic reintegration of the city within the national community, the government arranged public works, tax incentives, and special funds for the city. ${ }^{25}$ This set of provisions, however, only partially succeeded to overcome the chronic crisis of a city in which $15 \%$ of the local population remained unemployed. ${ }^{26}$

After 1954, Trieste's economic difficulties were instrumentally used by political parties of the Left and Right to weaken popular support for the Christian Democratic government. For example, the local Communist Party, aware of the economic isolation of the Triestine port, advocated the creation of a free trade zone between Trieste and its former Istrian region. ${ }^{27}$ Also the local Socialist Party, while attributing the decline of Trieste's port to its long-term separation from the Istrian hinterland, rhetorically advocated revisions to the London Memorandum. ${ }^{28}$

In commenting on the terms of this agreement, the national PCI leader Palmiro Togliatti claimed that "we cannot transform what is now provisional into definitive." This statement highlighted the problematic reconciliation of the national question with the ideological tradition of the party's internationalism and its new orientation toward a rapprochement with Yugoslav communism. ${ }^{29}$ Therefore, the Communist Party, while freezing the territorial issue and finally

\footnotetext{
${ }^{25}$ ACS, PCM, "Verbali adunanze," October 14, 1954.

${ }^{26}$ Governor Palamara, writing to President of Council Segni, highlighted that the reduction of unemployment and rise in maritime traffic benefited the local economy and dismissed the criticism of the first year of Italian administration; however, the status of the local economy remained significantly negative as noted in the report of 1956. UZC, Sezione IV, Busta 23, Folder Passaggio di Poteri nel Territorio di Trieste, "Palamara to Segni," December 23, 1955 and December 15, 1956.

${ }^{27}$ Vittorio Vidali "L'odierna situazione economica e sociale di Trieste e le sue prospettive," Rinascita (October, 1954).

${ }^{28}$ AFG, Fondo Apc, Serie Regioni e Province (RP), MF0429, "Rapporto Lonza al Consiglio Generale P.S.V.G.," January $15,1955$.

${ }^{29}$ AFG, Fondo Mosca, MF136, “Direzione del partito verbale," September 29, 1955.
} 
removing this "Cold War hotbed" from its political agenda, claimed to promote workers' interests by supporting Trieste's economic recovery, Adriatic friendship and international political relaxation. ${ }^{30}$ In Communist views the strife over Trieste's "Italianità" had decisively moved from the territorial to the economic dimension.

Triestine Communist leader Vittorio Vidali, however, continued to believe that "Titoists never abandoned the idea of conquering this territory as well" and feared Tito's ambitions to establish a chauvinist and violent socialist regime similar to the one ruling in the ex-zone B in Trieste. ${ }^{31}$ These views reflected widespread hostility among Communist Triestines toward Tito's regime and further separated the local from the national Communist movement. ${ }^{32}$ Consequently, many local Italians as well as Slovene communists re-oriented their political support toward the local Socialist Party. ${ }^{33}$

Despite this, external observers believed that people of Trieste, unable to understand the massive commitment of the Italian administration and too preoccupied with "bewailing the grimness of their economic present and future," could still resort to desperate measures and turn to communism. ${ }^{34}$ To respond to this threat and attempt to restore the local economy, the central government made Trieste one of the main beneficiaries of the Committee for the Economic Assistance to Northern Peripheral Areas. ${ }^{35}$ In so doing, central authorities indeed hoped to strengthen popular consensus toward the new Italian administration and consequently enhance the political support for the Christian Democratic governing elites.

Not only local communists but also the Independence Movement and its main political voice, the "Unione Triestina" (Triestine Union), could profit from popular disillusionment toward

\footnotetext{
${ }^{30}$ ACS, MI, Divisione Affari Riservati, 1954-1956, B.92, Folder Collaborazione PCI-PCJ, "Confidential Note to Police Chief," October 8, 1955.

${ }^{31}$ AFG, Fondo Vidali, Fascicolo 69 "Le dichiarazioni di Kruscev e i comunisti triestini," Il Colpo di Bora (May 5, 1955).

32،'Il P.C. triestino contro Krushcev,"Il Popolo (May 31, 1955).

${ }^{33}$ AFG, Fondo Apc, RP, MF0429, p.0699, “Anonymous note,” January 20, 1955.

${ }^{34}$ Arnaldo Cortesi, "Trieste's Economic Plight Dims Joy at Tie to Italy After 6 Months," The New York Times (April 6, 1955).

${ }^{35}$ ASL, Fondo Democrazia Cristiana, Segreteria Politica, Fanfani, Sc. 20, f.6, November 17, 1954.
} 
the Italian administration. ${ }^{36}$ In the words of the vice director of the Corriere di Trieste, Eugenio Laurenti, the Independence Movement's support was "directly related to citizens' prosperity."37 Anxieties over socio-political security and economic stagnation effectively favored the survival of the Independence Movement which found political support in the local lower and middle classes. ${ }^{38}$ Laurenti believed that the November 1954 outburst of Italian patriotism only temporarily overshadowed traditionally local feelings of "Central Europeanness and cosmopolitanness" within both the Italian and Slovene communities. ${ }^{39}$

A 1955 report from Giovanni Palamara, local head of the General Italian Government for the Territory of Trieste (GCGTT), further confirmed the intimate connection between the state's response to Trieste's needs and the strength of local Italian sentiments. Governor Palamara wrote that people in Trieste were increasingly disappointed by the ineptitude of the new Italian administration to stimulate the local economy, a problem not of mere political or economic consequence. ${ }^{40}$ The steady decline of Trieste's port, indeed, was promptly exploited by Yugoslav propaganda which highlighted the shortcomings of the new Italian administration. ${ }^{41}$ To respond, the Italian government financed a single economic and anti-communist network of local cooperatives that spread from Trieste to the hills of Carso. ${ }^{42}$

Anti-governmental parties, in particular, greatly profited from this situation and depicted the Italian state as a passive bystander to Trieste's decline. ${ }^{43}$ Also American observers related the endemic local economic crisis to the port's loss of Central European customers and the government's delays in following through with its previously announced economic plan to assist the

\footnotetext{
${ }^{36}$ The "Unione Triestina" was founded in 1955 and was centered upon a bourgeoisie coalition of anti-Slav sentiments. ACS, MI, Schedario Partiti Politici 1944-1966, B.106, fasc,312/P, Trieste Movimento Indipendentista, "Unione Triestina," April 4, 1955.

${ }^{37}$ Grassi, 27.

${ }^{38}$ Giampaolo Valdevit, Trieste: storia di una periferia insicura (Milano: Bruno Mondadori 2004), 69.

${ }^{39}$ Hametz (2005), 2.

${ }^{40}$ Archivio di Stato Trieste (AST), Fondo CGGTT, Pacco 2, Fasc. A, 3/14, Relazione Politica 1955, "Report from Palamara," November 15, 1955.

${ }^{41}$ Carlo Schiffrer, "Il dialogo a Trieste e nell'Istria," Il Ponte (August-September, 1955).

${ }^{42}$ UZC, Sezione V, Busta 13, Vol. I, Folder Trieste Federazione delle Cooperative e Mutue and Folder Trieste concentrazione democratica italiana delle Cooperative Operaie.

${ }^{43}$ Giusto Tolloy, "L’immobilismo a Trieste," Avanti! (June 19, 1955).
} 
Triestine port. ${ }^{44}$ It is noteworthy that neither the Italian government, nor the American administration understood the true catalyst of Trieste's crisis. ${ }^{45}$ After 1947, the new geo-political situation of the city had precluded Trieste from performing its traditional role as an economic center of a broad and highly integrated region. ${ }^{46}$ The port's economic potential, indeed, had been irreversibly affected by post-war reconstruction strategies that had massively relied on the external aid of the Marshall Plan. ${ }^{47}$ After 1948 the city's prospective maritime development was based upon short-term political considerations that privileged the massive influx of external investments to accelerate ship production in an unfavorable context of mass emigration and rising international marginalization. ${ }^{48}$ In attempting to compensate for the lack of technological innovation and the competitive advantage of airplane transport, this policy eventually created a dependent and unproductive economy which ultimately strengthened Trieste's expectations for massive state support. $^{49}$

As a consequence, Christian Democrats continued to pursue a paternalistic policy by sending significant flows of money toward Trieste. ${ }^{50}$ This strategy ultimately aimed to promote infrastructural innovation and increase maritime traffic with both the Austrian and Yugoslav neighbors. ${ }^{51}$ The government's initiatives, however, were highly debated between the central government and elements of the local political and economic elites who requested major regional autonomy and accused the Christian Democrats of nepotism in its privileging of specific local

\footnotetext{
${ }^{44}$ NARA, Foreign Intelligence Aid, Current Intelligence Weekly Summary, “Trieste Situation Deteriorates,” July 21, 1955.

${ }^{45}$ UZC, Sezione IV, Busta 36, Folder Mozione sui Problemi della Marineria e del Porto di Trieste, 1955.

${ }^{46}$ Furio Bednarz, "Crisi economica e governo della società,” ed. Ganapini (1986), 281.

${ }^{47}$ Colummi, ed. Ganapini (1986), 41.

${ }^{48}$ Giusto Tolloy, "Un anno fa a Trieste," Avanti! (October 26, 1955).

${ }^{49}$ Mellinato Giulio, "Tra mercato e propaganda; la ricostruzione del settore marittimo nella Trieste del secondo dopoguerra,"Acta Histriae 13 (2) (2005): 456.

${ }^{50}$ UZC, Sezione II, Trieste, Busta 50, Vol.I, Folder Bilancio del Territorio di Trieste, June-September, 1955.

${ }^{51}$ The Italian and Austrian governments signed a confidential protocol negotiating the tariffs for Trieste's port. The Austrian government proved critical of Triestine port's facilities and looked with interest to the rising competitiveness of Fiume's port. In spite of this and based upon reasons of mere economic convenience, it also expressed its intention to restore past prosperous traffic between Trieste and Austria. UZC, Sezione II, Fondo Trieste, Busta 51, Vol. II, Folder commercio di transito da e per Trieste, "Relazione sui colloqui avuti dalla delegazione triestina del P.S.D.I. a Vienna in merito ai problemi del porto di Trieste," September 6, 1955.
} 
economic groups. As a result, political cooperation among the major parties within the local council for trade and industry ended in $1955 .^{52}$

Meanwhile, proving sensitive to the complaints of the local entrepreneurial elites, the central government sought to restore Trieste's competitiveness by opposing the Yugoslav policies of economic dumping. ${ }^{53}$ To do so, it strengthened economic relations with the Yugoslav neighbor, despite diplomatic and political relations which still remained distant. ${ }^{54}$ For example, in January 1955, Italian and Yugoslav delegates began to negotiate a potential trade and navigation treaty. ${ }^{55}$ In August 1955, the signing of the Udine Agreements removed the status of partial embargo which, since October 1953, had constrained both the movement of people and the traffic of goods across the demarcation line between the ex-zones A and $\mathrm{B} .{ }^{56}$ The terms of the agreement were extended to all the areas within ten kilometers of the Italian and Yugoslav border as the movement of people became regulated by specific visas. ${ }^{57}$ In the following years, the Udine agreements covered a rising number of political and economic issues and a new text was released in 1963 yet their territorial extent remained substantially unchanged. ${ }^{58}$

Moreover, aware of the cumbersome issue of fishing in the upper Adriatic, Undersecretary of state Carlo Russo requested from the central government the immediate and urgent definition of an agreement to allow the free movement of fishing vessels between the ex-zones A and B of the former FTT in 1956. Italian violations of entering into Yugoslav territorial waters, indeed, often resulted in confiscation and detainment by the Yugoslav authorities. ${ }^{59}$ In connecting the signing of the fishing agreements to the liberation of the boats, the Italian authorities intended to prove to local

\footnotetext{
${ }^{52}$ UZC, Sezione II, Fondo Trieste, Busta 33, Vol. I, Folder enti economici a Trieste, "CGGT to PCM, Camera del Commercio di Trieste: nomina del Presidente e della Giunta," November 22, 1955.

${ }^{53}$ UZC, Sezione II, Fondo Trieste, Busta 51, Vol. II, Folder commercio di transito da e per Trieste, "CGGTT to PCM: Rapporto confidenziale sulla concorenza del porto di Fiume," March 24, 1955.

${ }^{54}$ Massimo Bucarelli, "Il Problema del confine orientale nella politica estera di Aldo Moro," in Aldo Moro nell'Italia contemporanea, ed. Francesco Perfetti, Andrea Ungari, Daniele Caviglia e Daniele De Luca, (Firenze: Le Lettere, 2011), 489.

${ }^{55}$ FBIS (January 21, 1955).

${ }^{56}$ Giorgio Cesare, "Una politica nuova," Trieste (September-October, 1955).

${ }^{57}$ UZC, Sezione IV, Busta 26 Vol. I, Folder negoziati Italia e Jugoslavia inerenti gli Accordi di Udine, "MAE to PCM," February 2, 1955.

${ }^{58}$ UZC,Sezione IV, Busta 26 Vol. II, Folder Nuovo Testo di Udine, "CGGTT to PCM," December 7, 1965.

${ }^{59}$ UZC, Sezione II, Fondo Trieste, Busta 43, Folder estensione della legislazione jugoslava alla ex zona B ed al distretto di Capodistria, "Notizie d'oltre frontiera," June 30, 1955.
} 
public opinion its firm commitment to Trieste when dealing with Tito's regime. ${ }^{60}$ In addition, Italian officers argued, the conclusion of such an agreement would strengthen the image of the Italian state among the Italians of the ex-zone B who were migrating to Italy, due to the arbitrary and repressive measures of the Yugoslav government. ${ }^{61}$

At the same time, the central authorities understood that the growth of the Yugoslav shipyard industry further weakened the Triestine economy ${ }^{62}$ In an effort to counter increasing public criticism, the local government also promoted a set of propaganda initiatives such as the "Mostra Viaggiante del Porto di Trieste" (Trieste Port Exhibition) of 1956 or the "Fiera di Trieste" (Trieste Fair) of 1957 and 1958 which aimed to project an image of a prosperous port. Financial funding for such initiatives, however, significantly fluctuated, adversely affecting their success. ${ }^{63}$

To better respond to the new geo-political configuration of the eastern border and minimize popular discontent, the central government also established a special office whose goal was to act as a liaison between the local government, the State Presidency of Council, and the Ministry of Foreign Affairs. This new office was perceived by local public opinion as a sign of uncertain Italian sovereignty over Trieste; however, it became a valuable means to monitor the behavior and attitudes of the Yugoslav government while pursuing a set of commercial and diplomatic agreements. ${ }^{64}$ For example, after the confidential and informal talks in 1956, Italian and Yugoslav negotiations for the final delimitation of the northern territorial border around Gorizia quickly accelerated. ${ }^{65}$ The definitive territorial settlement of the border between the former zones of the

\footnotetext{
${ }^{60}$ MAE, Telegram 5313, Belgrade to Rome, March 29, 1956.

${ }^{61}$ UZC, Sezione II, Fondo Trieste, Busta 43, Folder estensione della legislazione jugoslava alla ex zona B ed al distretto di Capodistria, "MI to MAE," September 15, 1956.

${ }^{62}$ UZC, Sezione II, Fondo Trieste, Busta 44, Vol. I, Folder provvedimenti presi dalle autorità jugoslave nei territori ceduti per effetto del Trattato di Pace e dopo gli Accordi di Londra, "CGGTT to PCM," April 24,1956.

${ }^{63}$ The Ministry of Trade and Industry refused any financial support due to the lack of available funding. UZC, Sezione II, Fondo Trieste, Folder 14 2, Fiera di Trieste, "Correspondence Palamara and Ministry of Trade and Industry," 1956, 1957, 1958.

${ }^{64}$ UZC, Sezione IV, Zone di Confine all’Ufficio Regioni (Trieste e Provincia), Busta 2, Folder Trieste Ministero degli Affari Esteri, Ufficio di Collegamento, "CGGTT to PCM," November 21, 1958.

${ }^{65}$ UZC, Sezione II, Fondo Jugoslavia e Varie, Busta 4, Folder delimitazione confine italo jugoslavo atti 1956 e 1957.
} 
FTT as well as the delineation of the territorial waters, however, remained unresolved. ${ }^{66}$ Moreover, the clandestine entrance of Yugoslav refugees and military personnel ${ }^{67}$ across the demarcation line as well as sporadic incidents between Italian and Yugoslav frontier guards, continued to strain Italian-Yugoslav relations. ${ }^{68}$

In this climate of Trieste's economic crisis and diplomatic uneasiness, the municipal elections of April 1956 became a crucial test of popular support for the new Italian administration and were accompanied by months of anti-governmental propaganda. The Italian government's financial contributions to the Slovene minority in Trieste, notably its support for a Slovene House of Culture, were locally perceived as violations of the principle of reciprocity stated in the London agreements and made Italians in Trieste feel like second-class citizens. ${ }^{69}$ At the same time, however, the arrest of former Slovene partisans, the expropriation of Slovene properties, and the ban on the use of Slovene language in the city center exposed the existence of Italian discrimination toward the city's Slovene minority. ${ }^{70}$

In particular, each local political party opposing the centrist governmental coalition used the city's problematic transition under Italian administration to weaken popular support for both central and local authorities. The neo-Fascist Party (Italian Social Movement, M.S.I.), for example, used the government's concessions to the local Slovenes to criticize the new Italian administration. ${ }^{71}$ In its public campaign, it emphasized that the government's policies had not only overlooked Yugoslav discrimination in the ex-zone B but had also enabled the process of Slav cultural

\footnotetext{
${ }^{66}$ In 1959 the Italian and Yugoslav governments signed an indefinite agreement on railroad traffic in Gorizia and began talks for the delimitations of the territorial waters. The signing of the agreement, which was anticipated by the visit of undersecretary Folchi in Belgrade, was praised by both Italian and Yugoslav public opinion as a leading example of the fruitful diplomatic climate of "active coexistence." FBIS (November 17, 1959).

${ }^{67} \mathrm{UZC}$, Fondo Jugoslavia e Varie, Busta 12, Vol. II, Folder espratri e sconfinamento in territorio italiano di militari iugoslavi, "Reports from CGGTT to PCM," 1956-1962.

${ }^{68}$ UZC, Fondo Jugoslavia e Varie, Busta 12, Vol. I, Folder incidenti lungo la fascia di confine italo-iugoslavo, "Ingressi in Italia di esuli iugoslavi," 1956.

${ }^{69}$ AST, Fondo CGGTT, Pacco 2, Fasc. B, 3/14, Relazione Politica 1956, "Confidential Note to Palamara," February 27, 1956.

${ }^{70}$ Jozè Pirjevec and Kacin, Milica, Storia degli sloveni in Italia (Padova: Marsilio, 1999), 112.

${ }^{71}$ UZC, Sezione II, Fondo Trieste, Busta 74, Folder Movimento Sociale Italiano Federazione Provinciale di Trieste,

"CGGTT to PCM, Movimento Sociale Italiano," January 14, 1956.
} 
penetration of Trieste. ${ }^{72}$ While embracing the opposing argument and under pressure from Moscow, the local Italian Communist party also intensified local propaganda against the new Italian administration. ${ }^{73}$ The Triestine Communists, following the Twentieth Soviet Party Congress and modifying their previously strong anti-Titoist stance, now highlighted Italian violations of the London agreements while, at the same time, attempting to tighten their local ranks. ${ }^{74}$ For its part, Social Democrats rejected extremist propaganda and emphasized the value of widespread administrative autonomy to better harmonize the legislative provisions of the London Memorandum and adequately protect Italian interests in the region. ${ }^{75}$ Thus, fearing any declaration that hinted at recognition of full Yugoslav sovereignty over zone B, the local Christian Democrat Giacomo Bologna suggested to Fanfani that its provisional status be maintained while gradually replacing the state administrative unit in Trieste with the administrative structure of an autonomous region. ${ }^{76}$

Also, aware of the strength of anti-governmental propaganda, local governor Palamara invited Rome to take symbolic actions that could prove its commitment to defend the Italian identity of the city and dismiss charges of subservience toward Tito. ${ }^{77}$ For example, Palamara asked the government to gain restitution of three Italian properties in the ex-zone B before making any further concession to the Slovene minority. ${ }^{78}$ The central government, also concerned with the attempt of local political leaders to create a lay and socialist coalition in opposition to the Christian Democratic Party, welcomed Palamara's idea and intensified its propaganda. ${ }^{79}$ In using the weekly journal of a local association affiliated with the Christian Democrats, the government highlighted

\footnotetext{
${ }^{72}$ UZC, Sezione II, Fondo Trieste, Busta 74, Folder Movimento Sociale Italiano Federazione Provinciale di Trieste, "CGGTT to PCM, Movimento Sociale Italiano," February 27, 1956.

${ }^{73}$ AST, Fondo CGGTT, Pacco 2, Fasc. B, 3/14, Relazione Politica 1956, "Confidential Note from Palamara," March 16, 1956.

${ }^{74}$ UZC, Sezione II, Fondo Trieste, Folder organizzazioni clandestine del P.C. di Trieste, "Confidential CGGTT to PCM, attività politica del P.C. di Trieste," March 16, 1956.

${ }^{75}$ Giorgio Cesare, "Trieste 1956," Trieste (January-February, 1956).

${ }^{76}$ ASL, Fondo Democrazia Cristiana, Segreteria Politica, Fanfani, Uffici Centrali-Corrispondenza, Sc.76, s.fasc.7, "Bologna to Fanfani," March 6, 1956.

${ }^{77}$ This measure was intended to reduce the strong disaffection among the incoming émigrés whose properties' value was decreased from 130 to 45 billion liras during the negotiations of the London Memorandum. AST, Fondo CGGTT, Pacco 2, Fasc. B, 3/14, Relazione Politica 1956, "Memorandum," June, 1956.

${ }^{78}$ UZC, Sezione II, Fondo Trieste, Busta 38, Folder elezioni amministrative nel Territorio di Trieste, "Attività preelettorale dei partiti politici di Trieste," April 6, 1956.

${ }^{79}$ UZC, Fondo contributi, sussidi e spese, Busta 4, Folder Trieste Ente Nazionale Assistenza Lavoratori,

"Correspondence between Palamara and PCM," March 21, 1955-April 10, 1956.
} 
the achievements of the Italian administration in Trieste and ultimately intended to weaken local communist support. $^{80}$

The election results saw a significant decline in votes for the local Christian Democrats as well as the republican and communist parties, which paralleled growing support for the neo-Fascist Party. ${ }^{81}$ The Independence Movement, excluded from participation in the local elections due to a set of procedural reasons, experienced a gradual decline which ended in 1959 with the closure of its journal, which was financed and controlled from Belgrade. ${ }^{82}$ Its supporters gradually merged their votes with those of the Triestine Communist Party which appropriated its programmatic platform calling for an independent Trieste. ${ }^{83}$ Talks between Italian and Yugoslav communists, however, confirmed the partition of the Triestine territory as definitive and Italian delegates depicted the "Trieste question" as an experience that had been "bothersome for you and painful for us." "84

In commenting on the electoral results, Palamara interpreted the decline in support for the Christian Democrats as a clear sign of local political apathy and weakness of the state's patriotic rhetoric. ${ }^{85}$ For his part, Mayor Gianni Bartoli explained the outcome of the elections as a consequence of the concessions to the Slovene minority, the government's unilateral implementation of the London Memorandum, and its mistakes in arranging local propaganda. ${ }^{86}$ Palamara had indeed mistakenly encouraged the central government to deny the Istrian C.L.N. any form of financial support, a decision that adversely affected support for the Christian Democrats among the émigrés in Trieste. ${ }^{87}$

\footnotetext{
${ }^{80}$ UZC, Sezione II, Fondo Trieste, Busta 38, Folder Elezioni Amministrative nel Territorio di Trieste, "CGGTT to PCM, organizzazione anticomunista oltrecortina," April 17, 1956.

${ }^{81}$ See Guido Botteri, "I voti dei triestini," Trieste 14 (1956): 2-11.

${ }^{82}$ Such a decision was part of a diplomatic agreement between Folchi and the Yugoslav diplomats in exchange for Italian commitment to close the Messaggero Veneto, a radical supporter of Italian territorial claims over the zone B. AST, Fondo CGGTT, Pacco 302, fasc. 18/2, I giornali di Tito a Trieste, "Palamara to PCM," February 24, 1960.

${ }^{83} \mathrm{AFG}$, Fondo Apc, RP, MF0444, p.1346, "Rapporto dell'incontro tra Arturo Colombi e Laurenti, direttore del Corriere di Trieste," July 14, 1956.

${ }^{84}$ AFG, Fondo Apc, RP, MF0447, p.1766, "Longo Report," October 5-16, 1956.

${ }^{85}$ AST, Fondo CGGTT, Pacco 2, Fasc. B, 3/14, Relazione Politica 1956, "Note from Palamara," May 31, 1956.

${ }^{86}$ AST, Fondo Bartoli, Busta 52, "Bartoli to Fanfani," June 4, 1956.

${ }^{87}$ UZC, Sezione II, Fondo Trieste, Busta 38, Folder Elezioni Amministrative nel Territorio di Trieste, "Commissariato Generale del Governo per il Territorio di Trieste (CGGTT) to Presidenza del Consiglio dei Ministri (PCM)," April 27, 1956.
} 
Although the results of the municipal elections effectively reflected people's anger over the state's failure to restore Trieste's economy, the local population still proved sensitive to symbolic expressions of national patriotism that, while recalling feelings of national unity, also minimized the sense of Trieste's isolation on the nation's periphery. ${ }^{88}$ These feelings responded to the deep sociopolitical anxiety of the local population for which even simple acts like Khrushchev's visit to Istria enhanced feelings of insecurity and fear. ${ }^{89}$ In his report to the central government, Trieste's chief of police, Domenico De Nozza, described the massive public participation in the celebrations of November 4, the anniversary of the entrance of the Italian troops in Trieste. Rituals such as the union of the waters of the Piave River with the soil of the Ardeatine caves inside San Giusto Cathedral symbolized the unique sacrifice of the martyrs of the Great War and Nazi-Fascist occupation. ${ }^{90}$ These rituals represented an idealized continuity between generations of Italians who died for national independence and, especially in the "unredeemed" city of Trieste, assumed a unique rhetoric and patriotic tone to which people enthusiastically responded. Rituals like these, however, could only alleviate temporarily the feelings of apathy toward the new Republic whose inability to resuscitate the local economy was broadly interpreted as a sign of neglect toward the city.

The strong discrepancy between the patriotic rhetoric of the government and its unsuccessful economic strategy for Trieste was not only criticized from communist or neo-fascist perspectives. Also local Catholic figures like Don Edoardo Marzari expressed their disapproval of the policies of the central government which had failed to stimulate local economic entrepreneurship. Nevertheless, the Catholic attempt to promote sentiments of national identity among the local Italian community that detached from past irredentist and cosmopolitan rhetoric, proved partially

\footnotetext{
${ }^{88}$ AST, Fondo CGGTT, Pacco 2, Fasc. B, 3/14, Relazione Politica 1956, "Trieste's Prefect De Nozza Note to Palamara on Closure of Rossetti Theatre," September, 1956.

${ }^{89}$ UZC, Sezione II, Fondo Trieste, Busta 45, Folder Jugoslavia e ex zona B del TLT situazione politica ed economica, "CGGTT to PCM: visita di Kruscev in Istria," September 25, 1956.

${ }^{90}$ AST, Fondo CGGTT, Pacco 2, Fasc. B, 3/14, Relazione politica 1956, "De Nozza to Palamara," December 1, 1956.
} 
successful. ${ }^{91}$ The activity of Catholic philanthropic associations such as "Figli del Popolo" (People's Children), indeed, succeeded in re-educating younger generations to the values of patriotism and Christian ethics. ${ }^{92}$ This success explains why the local Christian Democrats effectively contained the challenge posed by the anti-democratic movements of both fascist and communist inspiration. ${ }^{93}$

Due to Trieste's proximity to the border, however, popular support for the Christian Democrats was greatly affected by the government's response to Yugoslav policies toward the exzone B. For example, in the fall of 1956, the Yugoslav decision to resume compulsory military service in the ex-zone B provoked a wave of criticism of local patriotic and émigré associations. The Italian authorities, aware of the sensitive nature of the issue, also protested against the illegitimate nature of the Yugoslav action. ${ }^{94}$ Indeed, the Italian government, in categorizing the residents of the ex-zone B as Italian citizens, publicly demonstrated its formal consideration of the territory as indisputably Italian. ${ }^{95}$ At the same time, however, the decision to transform the Italian representation in Capodistria into an Italian Consulate, an institution traditionally located outside the national borders, revealed the contradictory behavior of the national government. ${ }^{96}$

Governor Palamara, carefully monitoring Triestine response to these events, reported that, although local public opinion was broadly interested in the news coming from the ex-zone B, people in Trieste generally reacted with calm to them. Triestines, indeed, were aware of the gradual absorption of the ex-zone B into the Yugoslav state and the rapid decline in the number of its Istrian population; however, he added, Triestines were increasingly frustrated with the unclear provisional

\footnotetext{
${ }^{91}$ Pelaschiar, 194.

${ }^{92}$ ACS, MI, Direzione General Assistenza Pubblica 1949-1977 (IPAB), Attività assistenziali italiane e internazionali, circolari (1945-1977), B. 642, Folder Trieste 1955-1975, Figli del Popolo per l'assistenza educativa e sociale della gioventú, "Report from Marzari," 1961.

${ }_{93}^{93}$ Millo (2011), 179.

${ }^{94}$ Archivio Unione Istriani (AUI), 1954-1967, Folder IV/6, "Confidential MAE to Unione Istriani," October 4, 1956.

${ }^{95}$ Rino Baroni, Gli istriani in difesa dell'Istria italiana: dal Memorandum d'Intesa al Trattato di Osimo (Trieste: Unione degli Istriani, 2004), 66.

${ }^{96}$ UZC, Sezione II, Fondo Trieste, Busta 43, Folder estensione della legislazione jugoslava alla ex zona B ed al distretto di Capodistria, "MAE to PCM," March 11, 1957.
} 
status of the London Memorandum, which they felt needed to be clearly declared either as provisional or conditionally definitive with amendments. ${ }^{97}$

To sum up, in the immediate years after 1954, restoration of Trieste's economy provided the main motivation behind the new border strategy of the central government. Indeed, while strenuously claiming Italian sovereignty over the ex-zone B, Italian political authorities provided financial support to Trieste and simultaneously pursued the normalization of political relations with the Yugoslav neighbor. Popular disappointment in the government's inability to fulfill its promises of economic prosperity, however, limited the effect of its patriotic rhetoric and ultimately undermined local support for the Christian Democrats.

\section{A New Christian Democratic Leadership for Trieste: Moving on a Progressive Path}

After the unsatisfactory results of the 1956 municipal elections, the Triestine Christian Democrats experienced a pivotal generational change in the second half of the 1950s. The new political class made of young Istrians, who identified with Christian Democratic leader Amintore Fanfani, replaced the old local conservative and clerical representatives and gradually opened their ranks to the leftist forces of the political spectrum. This new elite distanced itself from the previously intransigent nationalist rhetoric that had driven the battle for Trieste's "Italianità," yet nationalist views survived among local Italians. Indeed, on the occasion of the third anniversary of Trieste's November 1954 deaths, Governor Palamara reported an attempted attack of 4,000 students against the local headquarters of Communist and Slovene organizations. Episodes like these revealed the endurance of ethno-ideological tension between segments of the local Italian youth and Slovene communities, the former of which was still highly affected by nationalist propaganda. ${ }^{98}$

At the same time, the change inside the local Christian Democratic leadership also produced the progressive marginalization in Triestine politics of previously relevant figures such as former

\footnotetext{
${ }^{97}$ UZC, Sezione IV, Busta 83, Folder Servizio Militare, "CGGTT to PCM, opinione triestina sul Memorandum," September 25, 1956.

${ }^{98}$ MAE, Telegram 25923, "Trieste to Rome," November 6, 1957.
} 
Mayor Gianni Bartoli and Bishop Antonio Santin. The end of the logic of the Italian bloc in Trieste, a key element of the governmental strategy during the years of the "Trieste question," paved the way for greater Christian Democratic openness toward the Social-Democrats. This political process, which had been inaugurated by Fanfani at the national level in 1954, was delayed in Trieste and saw the affirmation of the most progressive faction of the Christian Democrats only in $1959 .{ }^{99}$

In Trieste, this new political configuration further undermined local support for the Independence Movement and minimized former antagonism between the national Christian Democrats and the local municipal authorities, who were traditional supporters of a pro-Italian solution of the Triestine question defined in terms of broad administrative autonomy. ${ }^{100}$ Figures such as Bartoli, however, expressed his concern for a political shift that threatened to further widen the gap between the people and the state in Trieste. In his speech of 1957 at the Julian and Dalmatia circle in Milan, Bartoli claimed that Trieste's problems remained largely unresolved after 1954 and Triestines were perceived as "complainers who did not even know what they wanted." 101 These views, Bartoli claimed, ignored the problematic status of the city which he compared to a human head deprived of its body.

Indeed, the progressive strengthening of Capodistria's port facilities, which revealed Yugoslav intentions to transform the city into a key entry point to the upper Adriatic, harmed Trieste's own maritime traffic. ${ }^{102}$ In addition, the sustained growth of Fiume's port and the expansion of Hamburg, Bremen, and Rotterdam's ports further undermined Trieste's competitiveness with Europe more broadly. In particular, Fiume's traffic with Hungary and Czechoslovakia benefited from geo-political factors and its privileged connection to the Danubian hinterland from which Trieste remained partially excluded. ${ }^{103}$ All these factors made Trieste

\footnotetext{
${ }^{99}$ See Diego D'Amelio, "Il cambio della guardia. Correnti, generazioni e potere nella Democrazia Cristiana di Trieste (1954-1966)" Quaderni del centro studi economico politici Ezio Vanoni (3-4) (2009): 1-64.

${ }^{100}$ See Roberto Spazzali, "Gianni Bartoli e il suo tempo: politica e società triestina dal 1949 al 1957" ed. Tatò, 19-28.

${ }^{101}$ ACS, MI, Gabinetto, Fasc. Correnti, 1957-1960, B.269, Fasc. 15726/1 Trieste, March 6, 1957.

${ }^{102}$ UZC, Sezione II, Fondo Trieste, Busta 51, Vol.II., Folder movimento nel porto di Capodistria, "MAE to PCM: costruzione del porto di Capodistria," August 19, 1957.

${ }^{103}$ UZC, Sezione II, Trieste, Busta 51, Vol. II., Folder concorrenza del porto di Fiume, "MAE to PCM: Trieste e Fiume traffici portuali," April 30, 1958.
} 
particularly vulnerable to national and international events. ${ }^{104}$ Thus, only a global approach to the Triestine economy could facilitate the restoration of its port's traffic; however, the tension between the centralizing impulses of the national government and the autonomous ambitions of the local economic elite for greater autonomy adversely affected this possibility. ${ }^{105}$

Indeed, the views of the President of the local council for trade and industry, who sought the creation of a free economic zone, clashed with the strategy of the local representative of the central government. ${ }^{106}$ As a result, the national government dissolved the sitting local council and, on the basis of existing legislation, appointed a new council with a President of Christian Democratic orientation with expertise on port issues. ${ }^{107}$ This decision, clearly motivated by the unwillingness of the national government to make concessions to demands for greater autonomy, was therefore perceived locally as a clear sign of revenge. ${ }^{108}$

Nonetheless, parts of the local community recognized the commitment of the central government to restore local prosperity. For example, the Istrian C.L.N. criticized members of the independence movement whom, while profiting from the magnanimity of the Italian government and disregarding the expanding volume of local consumption as well as rising employment, were "sticking their heads out of the sand." 109 At the same time, however, the C.L.N. harshly criticized the Italian government for its mild defense of both Italian territorial claims and culture in the exzone B. ${ }^{110}$ In this fashion, the 1958 agreement on Italian access to Yugoslav territorial waters, made possible by a significant payment from the Italian government, was portrayed locally as a sign of

\footnotetext{
${ }^{104}$ AST, Fondo CGGTT, Pacco 2, Fasc. C, 3/14, Folder relazione politica 1957, "Report from Palamara," January 3, 1958.

${ }^{105}$ UZC, Sezione IV, Busta 23, Folder passaggio di poteri nel Territorio di Trieste, "Ministry of Treasury to PCM," April 19, 1957.

${ }^{106}$ Giulio Sapelli, Trieste italiana. Mito e destino economico (Milano: Franco Angeli, 1990), 172-195.

${ }^{107}$ UZC, Sezione II, Fondo Trieste, Busta 33, Vol. I, Folder enti economici a Trieste, "CGGT to PCM, scioglimento della Giunta Camerale e nomina del nuovo Presidente," February 28, 1958.

${ }^{108}$ See Aleksander Panjek and Chiara de Draganich Veranzio, "Ricostruzione, lavoro, e immigrazione di manodopera specializzata nel dopoguerra triestino," ed. Verrocchio (2004).

${ }^{109}$ AST, Fondo CGGTT, Pacco 38, Fasc. 3/1, Indici III anno di amminstrazione italiana a Trieste, "Almerigogna to Palamara," January 11, 1958.

110 "Sacrificati i nostri pescatori a vantaggio dei conservifici jugoslavi," Il Piccolo (November 22, 1958).
} 
indisputable political weakness and was harshly criticized for its unclear benefit to Istrian fishermen. $^{111}$

In anticipating the municipal elections of 1958 , these issues were exploited by both the local neo-fascist and communist movements. Neo-fascist propaganda stressed the party's invaluable role in opposing the communist threat to Trieste's "Italianità" and expressed support for local neoirredentism by organizing street demonstrations, which often resulted in vandalism of Slovene and resistance monuments. ${ }^{112}$ Palamara, concerned about an exacerbation of ethnic antagonism between Italians and Slovenes and possible Yugoslav reactions, called upon the central authorities to deny the authorization for a planned demonstration of the neo-fascist youth association "Giovane Italia" (Young Italy). ${ }^{113}$ The central government's fears for the detrimental effect of local expressions of neo-irredentism on Italian-Yugoslav diplomatic relations resulted in the suspension of the state's financial contributions to neo-fascist associations. ${ }^{114}$ Although local and national Christian Democrats proved certainly less tolerant toward visible expressions of resurgent Fascism in and outside Trieste, the existence of right-wing parallel structures outside the control of the state intelligence agency demonstrated the strong anti-Communism of fringes of the governing elites. ${ }^{115}$

In such a context, the national PCI exploited the problematic re-birth of the Triestine economy for political goals and stressed the central authorities' ineptitude to advance political relaxation with the Yugoslav neighbor, an outstanding example of socialism. ${ }^{116}$ In Trieste, local Communist leader Vittorio Vidali and his followers, however, continued to distrust Tito's regime and firmly opposed any Titoist organizations while also actively supporting the anti-Titoist network

\footnotetext{
${ }^{111}$ ASR, Sezione I, Attivitá Politica, Serie 1, ss.5, Busta 34, fasc.1, “Folder Ministero Affari Esteri,” August 1958January, 1959.

${ }^{112}$ AST, Fondo CGGTT, Pacco 14, Fasc. 13/4, Danni ai monumenti sloveni, "Note from De Nozza to Palamara," April 27, 1957.

${ }^{113}$ UZC, Sezione II, Fondo Trieste, Busta 74, Folder Movimento Sociale Italiano Federazione Provinciale di Trieste, "CGGTT to PCM, "Manifestazione Giovane Italia," November 6, 1957.

${ }^{114}$ ACS, MI, Divisione Affari Riservati 1957-1960, B.59, Folder associazione feriti e famiglie caduti per la causa nazionale di Trieste, "Report from Palamara," October 3, 1958.

${ }^{115}$ Pacini, 59.

${ }^{116}$ AFG, Fondo Apc, RP, MF0455, p.0836, “Programma elettorale Comitato Centrale,” January 20, 1958.
} 
in the ex-zone B. ${ }^{117}$ Furthermore, the Triestine communists firmly supported the creation of an autonomous region as the best means to realize a free economic trade zone and advance the interests of Trieste's workers. ${ }^{118}$ In its campaign against the central government, the party greatly exploited people's anger over the prolonged crisis of the local economy which resulted in waves of mass strikes. $^{119}$

To contain the loss of popular support inside the city, the national government promptly announced a plan of investments for Trieste and a set of initiatives to foster the social re-integration of the Adriatic émigrés. Moreover, Palamara, increasingly irritated by communist propaganda, denied the local Communist party permission to hold its political meeting in the main Triestine square because the use of the Slovene language "would be offensive to the national and patriotic feelings of the majority of the local population." ${ }^{20}$ This emphasis on Trieste's patriotic feelings responded to the necessity to defy both nationalist propaganda against the government and the pressure from a variety of veteran associations. ${ }^{121}$ Indeed, on November 4, 1958, the government arranged patriotic manifestations that proclaimed an imagined unity of the cities of Trento and Trieste and celebrated the sacrifice of the Triestine martyrs of World War One as sublime proof of the spiritual unity between the city and the homeland. ${ }^{122}$ Despite these efforts, the national elections of 1958 saw the significant weakening of the Christian Democrats and the growing strength of leftwing and extremist parties, especially the neo-fascist M.S.I. ${ }^{123}$

In addition, the traditional domain of the Christian Democrats in Triestine politics was further challenged by the re-appearance of new independent political formations. On May 21, 1959,

\footnotetext{
${ }^{117}$ The Triestine Federation was beset from internal tensions between loyal Stalinists and its antagonists, who embraced the new course of national politics and the openness toward the left. AFG, Fondo Apc, RP, MF0461, p.1773, "Note from Giacomo Pellegrini," March 21, 1959 and AFG, Fondo Apc, RP, MF0470, p.2955, "Anonymous letter from a Triestine group of anti-Stalinists," April 4, 1960.

${ }^{118}$ Gino Beltrame, "La quinta regione," Atti Parlamentari (AP), Camera dei Deputati, June 19, 1962.

${ }^{119}$ UZC, Sezione II, Fondo Trieste, Folder attività del P.C. di Trieste, "Confidential Note from Government's Cabinet to Ministery of Work and Welfare," December 10, 1958.

${ }^{120}$ UZC, Sezione II, Fondo Trieste, Busta 38, Folder elezioni amministrative nel Territorio di Trieste, "Note of Palamara," October 3, 1958.

${ }^{121}$ ASL, Fondo Democrazia Cristiana, Segreteria Politica, Fanfani, Sc. 52, f.79, "Letter from movimento reduci di guerra to segreterie DC," May 29, 1958.

122، Oggi Trento e Trieste celebrano la vittoria,” Il Popolo (November 3, 1958).

${ }^{123}$ Vezzà and Comelli, 89.
} 
a group of Triestine residents established a new independence formation, the Movement for the Independence of the Free Territory of Trieste which aimed its activities at the larger population of the Triestine territory. ${ }^{124}$ Through the pages of local journals such as Trieste Sera or L'Indipendenza, the movement re-asserted the nexus between Trieste's political independence and its port's economic prosperity. In an effort to mobilize international public opinion, the movement symbolically sent letters and memoranda to international organizations such as the UN and to key political figures, including US President Eisenhower and Soviet Secretary Khrushchev, to seek support for the creation of the FTT. ${ }^{125}$ Inside the Triestine territory, however, political support for the movement and other similar political formations remained minimal.

Despite its relative marginalization, the movement's strong anti-governmental tone and propaganda inflamed the local and national debate on issues such as the city's irreversible economic decline and the unclear territorial sovereignty over parts of the border region. In its public campaign, the movement first criticized Italian subservience to the pro-Yugoslav attitude of both the American and Austrian governments which had diverted their traffic toward Fiume. ${ }^{126}$ Second, it depicted the construction of a civil airport in Fiume and a hydroelectric dam in Capodistria as fatal blows to Trieste's already crumbling economy. ${ }^{127}$ Finally, it disputed the legitimacy of a General Government for Trieste, an institution that was previously sponsored by the Allied government and now unnecessary due to the Italian government's declared sovereignty of Trieste. ${ }^{128}$ Such issues found resonance within the local public sphere and were used to further weaken the state's image in Trieste. At the press conference held on the five-year anniversary of the restoration of Italian administration in Trieste, Palamara first rhetorically praised the passionate feelings of "Italianità" that drove the actions of the Triestine martyrs in 1953 and highlighted the

\footnotetext{
${ }^{124}$ In 1959 this movement succeeded the "Fronte Indipendente" of 1958 in which independent political formations of the "Unione Triestina" had previously merged. ACS, MI, Schedario Partiti Politici 1944-1966, B.106, fasc. 312/P, Trieste Movimento Indipendentista, "Confidential Note to Gabinetto," June 10, 1959.

${ }^{125}$ UZC, Sezione II, Fondo Trieste, Busta 93, Folder Trieste Movimento per l'Indipendenza del T.L.T. "CGGTT to PCM, Trieste attività dei movimenti indipendentisti," September 30, 1959.

${ }^{126}$ UZC, Sezione IV, Busta 48, Folder Porto di Trieste, "Palamara to Under Secretary of State," November $13,1959$.

${ }^{127}$ UZC, Sezione II, Fondo Trieste, Busta 43, Folder Capodistria, "CGGTT to PCM," April 13, 1960.

${ }^{128}$ ACS, MI, Schedario Partiti Politici 1944-1966, B.106, fasc. 312/P, Trieste Movimento Interdipendentista,

"Confidential Note MAE to PCM," November 23, 1961.
} 
positive trends in employment and productivity. ${ }^{129}$ In commenting on local pessimism, Palamara pointed to an unjustifiably low morale among the general population and also stressed its detrimental effect on potential investors. ${ }^{130}$

Local public opinion in Trieste, however, showed little interest in Palamara's press conference and instead devoted specific attention to the November 4 anniversary of national liberation from Austria-Hungary. ${ }^{131}$ This occurrence was widely advertised by a variety of local neo-irredentist groups that also partially mimicked neo-fascist propaganda. National patriotic associations also used the opportunity to criticize the central government for its feeble protection of the rights of the Italian minority in zone B and depicted the Slovene bank as well as Slovene cultural circles in Trieste as clear signs of Slav penetration. ${ }^{132}$ In their public campaign, they asked the central government to not "make the Italian majority of Trieste pay for the nationalist mistakes of the fascist past." ${ }^{133}$ At the same time, however, patriotic groups of democratic inspiration also firmly condemned the local neo-fascist movement whose rhetorical defense of Trieste's Italian identity was accompanied by acts of unacceptable political violence, such as the bombing of Slovene commemorative sites. ${ }^{134}$

In the late 1950 s, these more moderate views were broadly shared among the local Italianspeaking population whose political preferences increasingly turned toward a local political progressive coalition, which was composed of Social and Christian Democrats. ${ }^{135}$ Also Gianni Bartoli, an indefatigable defender of Italian territorial claims over Trieste and its Istrian region, suggested that Trieste's Christian Democratic secretary Corrado Belci strengthen political relations with the Social Democrats and distrust the political forces that not only failed to recognize the

\footnotetext{
129،"Trieste ha celebrato il ritorno all'Italia," Il Popolo (October 27, 1959).

${ }^{130}$ UZC, Sezione IV, Busta 23, Folder passaggio di poteri nel Territorio di Trieste, "Palamara Public Press," October 26, 1959.

${ }^{131}$ Umberto Segre, "Trieste cinque anni dopo," Il Ponte (September, 1959).

132،"Il voto slavo a Trieste sollecitato e contrattato dalla DC," Il Secolo (January 22, 1960).

${ }^{133}$ Giuseppe Tramarollo, "Umanità senza nazioni non può esistere: la situazione di Trieste," Il Pensiero Mazziniano (November 15, 1959).

${ }^{134}$ In particular, AST, Fondo CGGTT, Pacco 136, Fascicolo 13/14, Vigilanza sedi partiti e associazioni, "Confidential Note to Palamara," June 9, 1960.

${ }^{135}$ AST, Fondo Bartoli, Busta 47, Rapporti con il mondo politico, "Bartoli’s Speech," March 19, 1959.
} 
democratic nature of the new political system but had also cast doubts on the "Italianità" of Trieste and its territory. ${ }^{136}$

Trieste's experience of a progressive coalition government followed the path of Fanfani's government in 1958 which, opening to the Social Democratic Party and the Republican Party, significantly departed from the practice of former post-war governments of conservative orientation. This process, however, proved to be complex but reversible and the Christian Democrats created a new coalition government which, under the leadership of Christian Democrat Fernando Tambroni, relied on the support of the neo-Fascist Party in 1960. This coalition government, however, also quickly fell apart. Indeed, during the summer, the government's decision to allow the neo-Fascist Party to hold its national convention in Genoa provoked a massive wave of local and national demonstrations that resulted in violent skirmishes between workers, partisan associations, and the local police. These dramatic events fatally undermined political and popular support for Tambroni's government which was forced to resign. As a result, the neo-Fascist Party, which had been previously involved in the coalition government, was relegated to the margins of national politics. ${ }^{137}$ Thus, in the early 1960 s, Christian Democrats turned again toward the formation of center-left coalition governments. ${ }^{138}$ As I explore in detail in the next chapter, this process of Christian Democratic openness toward the left was met with specific resistance in the Triestine context as some factions of the local Christian Democrats feared the strengthening of the Communist Party. ${ }^{139}$

Meanwhile, reports from local Christian Democrats and local authorities demonstrated that the party's popularity increasingly depended on the state response to Trieste's economic needs. ${ }^{140}$ Corrado Belci, in a set of letters to Christian Democrat national secretary Aldo Moro, repeatedly asked for approval of a free industrial zone to defy Yugoslav competition and accelerate Trieste's

\footnotetext{
${ }^{136}$ ASL, Fondo Mario Scelba, Versamento II, Corrispondenza, B.17, f.199, “Bartoli to Belci,” June 10, 1960.

${ }^{137}$ See Philip Cooke, Luglio 1960: Tambroni e la repressione fallita (Milano: Teti Editore, 2000).

${ }^{138}$ Andrea Ungari, "Aldo Moro e il Movimento Sociale Italiano," ed. Perfetti, 238.

${ }^{139}$ ASR, Sezione I, Attivitá Politica, Serie 1, ss.4, Busta 11, fasc.4, Correspondence from Genoa. ASR, Sezione IV, Diari Fanfani, 1960.

${ }^{140}$ UZC, Sezione IV, Busta 52, Folder Trieste situazione economica generale, "Belci to Moro," August 24, 1960.
} 
economic recovery. ${ }^{141}$ In addition, Palamara reported to the central government that local fears of the existence of secret clauses in the London Memorandum and the absence of a programmatic industrial plan for Trieste made the city more sensitive to the rising competitiveness of Fiume's port and weakened its public spirit. ${ }^{142}$

Local representatives and entrepreneurs, indeed, called for the government's intervention to accelerate the modernization of the industrial network, reduce maritime tariffs, build up the local airport, and improve the highway system to facilitate the connection between the Adriatic littoral, the city, and the Austrian region. ${ }^{143}$ In response, the national government pursued a set of economic agreements with the main countries of the Adriatic region to facilitate the maritime traffic through the Triestine port. ${ }^{144}$ Moreover, Christian Democratic secretary Aldo Moro exerted political pressure on the government to assign to the city of Monfalcone the construction of a new ship that could temporary provide work to about 2,500 unemployed workers. ${ }^{145}$ Measures like these show that the central government and the Christian Democrats proved extremely concerned about the political implications of Trieste's economic crisis yet were unable to reduce public disillusionment. ${ }^{146}$

During the late 1950s and early 1960s, the government's political opponents had indeed increasingly used Trieste's steady economic impoverishment, its demographic decline, and the presence of a large number of émigrés still located in its refugee camps to highlight the government's ineffectiveness to facilitate the city's socio-economic reintegration. ${ }^{147}$ In addition, the national government's plan to grant local administrative autonomy to the Julian Venetian region

\footnotetext{
${ }^{141}$ ASL, Fondo Democrazia Cristiana, Segreteria Politica, Moro, Corrispondenza con gli organi periferici, Sc.131, s.fasc.3, "Belci to Moro," April 27, 1959.

${ }_{142}$ AST, Fondo CGGTT, Pacco 122, Fasc.3/14, Relazione politica 1960, "Palamara Report," June, 1960.

${ }^{143}$ UZC, Sezione IV, Busta 7, Vol. I, Folder Trieste censimento generale della popolazione, "Local Secretary Belci to President of Council Fanfani," November 23, 1961.

${ }^{144}$ UZC, Sezione IV, Busta 48, Folder Porto di Trieste, "Meeting PCM on Trieste’s Port Traffic," July 18, 1961.

${ }^{145}$ ASL, Fondo Democrazia Cristiana, Segreteria Politica, Moro, Corrispondenza con il Governo, Sc.147, fasc.14, "Moro to Andreotti," October 6, 1960.

${ }^{146}$ UZC, Fondo Jugoslavia e Varie, Busta 14, Vol. II, Folder accordo italo-jugoslavo per gli scambi locali fra Trieste e le zone limitrofe, "Letter to President of Council Fanfani," December 14, 1960.

${ }^{147}$ UZC, Sezione II, Fondo Trieste, Busta 68, Folder Lega Nazionale concessione di contributi finanziari, "Note from Under secretary Russo to Foreign Ministry Pella," August 17, 1959.
} 
and its policy of diplomatic normalization with Yugoslavia had been instrumentally used by the neo-fascist movement to argue that the government intended to recognize the definitive partition of the ex-zone B. ${ }^{148}$ These factors exacerbated socio-political tension in a frontier city such a Trieste which still looked at Tito's regime with deep suspicion.

Contrary to right-wing accusations of the government's subservience to advancing communism, Italy's new policy of Adriatic friendship actually intended to reach out to socialist countries in foreign policy in order to ultimately promote their autonomy from Moscow and reduce communist influence on domestic policy. ${ }^{149}$ As part of this policy, the Christian Democratic Party believed that the improvement of bilateral diplomatic relations with the Yugoslav neighbor could effectively facilitate the defense of the Italian minority living in the ex-zone B. In this fashion, the 1960 visit of the Yugoslav Foreign Minister Koča Popovic provided the Italian government the opportunity to discuss issues related to minority rights and re-open the negotiation of the northern border. At the same time, however, it confirmed that while the southern border between Trieste and the ex-zone B may have been considered definitive from a Yugoslav perspective, the Italian government still viewed it as provisional. ${ }^{150}$ These opposing Yugoslav and Italian interpretations of the London Memorandum, which well mirrored the views of their border communities, remained a bone of contention for the next fifteen years; however, the Adriatic neighbors significantly intensified their efforts to advance diplomatic negotiations over a variety of unresolved issues.

In 1961, for example, although Yugoslavia firmly refused to discuss the status of the demarcation line between Trieste and the ex-zone B by claiming its definitive and unchangeable nature, the Italian and Yugoslav governments agreed to proceed with the negotiation of minor

\footnotetext{
${ }^{148}$ ACS, MI, Gabinetto, Fasc. Correnti, 1957-1960, B.57, Fasc. 12010/85, “Trieste attività dei partiti,” November 23, 1959.

${ }^{149}$ Luciano Monzali, " I nostri vicini devono essere i nostri amici. Aldo Moro, l’Ostpolitik Italiana e gli accordi di Osimo," in Aldo Moro, l'Italia Repubblicana, e i Balcani, ed. Italo Garzia, Luciano Monzali, e Massimo Bucarelli (Nardò: Besa Editrice, 2011), 94-96.

${ }^{150}$ ACS, PCM, Ufficio Consigliere Diplomatico, Busta 27, Fasc. E47, Fasc. E 49, Visita in Italia del Ministro degli Esteri iugosalvo, Popovic, “Talks Segni-Popovic,” December 3, 1960.
} 
territorial disputes in the northern area of the Julian Venetian region. ${ }^{151}$ In addition, the Yugoslavs committed themselves to the removal of discriminatory practices against the Italian minority of the ex-zone B both in the administrative and educational matters. ${ }^{152}$ Consequently, the Yugoslav government decided to introduce bilingual teaching in Italian schools of the ex-zone B from the first grade, but also extended national legislation over the area now under Slovene and Croatian administration. According to Governor Palamara, such a provision violated the terms of the special statute of the London Memorandum which applied only to the former territory of Trieste. Palamara, indeed, feared that by accepting such an initiative, the Italian government itself would also be forced to extend bilingual schools outside Trieste, especially to Udine and Gorizia, cities with significant Slovene minorities. Therefore, Palamara advised the central government to limit the new legislation only to the former Triestine territory. ${ }^{153}$

This political development was also paralleled by the Italian government's initiative to organize seminars of Italian language for both teachers and high school students in the ex-zone B. ${ }^{154}$ This decision was enthusiastically received by the Italians living under Yugoslav administration which read it as a sign of the government's commitment to the defense of the Italian heritage of the region. ${ }^{155}$ As this case shows, the protection of linguistic rights for the Italians of the ex-zone B remained indeed a sensitive matter for the central government and consolidated local hopes for possible future revisions of the London Memorandum or at least the preservation of its provisional character.

At the same time, any reference to the definitive nature of the demarcation line established by the London Memorandum still had the potential to easily inflame local animosity toward

\footnotetext{
${ }^{151}$ AST, Fondo CGGTT, Pacco 168, Fasc. 2/4, Segni a Belgrado, "Secret Note General Direction Political Affairs MAE," July 17, 1961.

${ }^{152}$ UZC, Sezione II, Fondo Trieste, Busta 44, Vol. I, Folder situazione scolastica nell'ex-zona B del TLT, "Questioni bilaterali di carattere politico trattate nel corso delle recenti conversazioni di Belgrado," July 17, 1961.

${ }^{153}$ UZC, Sezione II, Fondo Trieste, Busta 44, Vol. I, Folder estensione della legislazione jugoslava alla ex zona B ed al distretto di Capodistria, "Confidential, CGGTT to PCM," August 5, 1961.

${ }^{154}$ AST, Fondo CGGTT, Pacco 168, Fasc. 2/4, Segni a Belgrado, "Undersecretary of State to MAE," September 23, 1961.

${ }^{155}$ UZC, Sezione IV, Busta 44, Folder contributi seminari di lingua e letteratura italiana in zona B, "Contributions 19611982."
} 
Rome. ${ }^{156}$ In 1962, for example, the political debate regarding the implementation of constitutional provisions for the creation of an autonomous Julian Venetian region provoked the protests of both émigrés and nationalist associations. ${ }^{157}$ They feared that the creation of an autonomous Julian Venetian region would strengthen the ambitions of the independence movement and, especially, sanction the definitive partition of the ex-zone B from Trieste. ${ }^{158}$

Widespread local opposition to the loss of formal Italian sovereignty over ex-zone B was motivated by a mix of nationalist and economic considerations. Given the failure of the government's economic strategy for the city, the future reunion between Trieste and its economic hinterland represented the only hope to restore economic prosperity. The central government, unwilling to take any decision that could impair Italian territorial interests along the border, subsequently postponed the establishment of the autonomous region until $1963 .^{159}$

In such a context, Prime Minister Amintore Fanfani, while promoting the government's Mediterranean over Atlantic interests and supporting political openness to the East, also sought to improve Adriatic commercial relations to better respond to Trieste's economic needs. ${ }^{160}$ Although Fanfani was locally perceived as an indefatigable defender of Italian interests in the Adriatic, he firmly pursued the political rapprochement toward Yugoslavia. Indeed, both Fanfani and Christian Democratic secretary Aldo Moro, who was later accused of political defeatism, inaugurated a new political season in Italian-Yugoslav relations. ${ }^{161}$ During his meeting with Yugoslav Minister of Internal Affairs Aleksandar Rankovic, Fanfani mainly discussed economic issues yet also was prepared to examine some adjustments to the northeastern border. ${ }^{162}$ In addition, both men restated

\footnotetext{
${ }^{156}$ Paul Underwood, "Trieste Debates Plan for Autonomy Under Italy," The New York Times (August 14, 1962).

${ }^{157}$ AST, Fondo CGGTT, Pacco 224, fasc. 2/2, Diritti sulla zone B del Territorio di TS, "Note to Ministry of Foreign Affairs," October 13, 1962.

${ }^{158}$ Archivio Lega Nazionale (ALN), Folder 1965/II, Segreteria Riservata, "Muratti to Mazza," April 6, 1962.

${ }^{159}$ ACS, PCM, Ufficio Consigliere Diplomatico, Busta 27, Fasc. E47, “Istituzione Friuli Venezia Giulia,” June 5, 1962.

${ }^{160}$ In a letter addressed to Fanfani, liberal representative Malagodi stressed the impending need for an efficient system of transportation and a suitable tariff policy to compete with Hamburg and Fiume and compensate for the loss of Trieste's Danubian hinterland. ASR, Sezione I, Attivitá Politica, Serie 1, ss.4, Busta 15, fasc.5, "Malagodi to Fanfani," October 27, 1962.

${ }^{161}$ See Evelina Martelli, "Da Fanfani a Moro. Continuità e rotture nelle linee della politica estera italiana,” ed. Perfetti, 309-337.

162،"Maggiori scambi con Belgrado dopo le migliorate relazioni," Il Popolo (June 15, 1962).
} 
the unfeasibility of any change in zone A as well as the maintenance of two-thirds of the Triestine territorial waters under Italian administration. ${ }^{163}$ In Fanfani’s views, the general economic agreement represented a necessary preamble to the strengthening of bilateral efforts to solve problems of mutual interest. ${ }^{164}$ This new approach to Italian-Yugoslav relations came to play a pivotal role in the making of the Osimo Treaty.

As discussed so far, popular anxiety and widespread distrust toward state institutions was motivated by the prolonged economic crisis which adversely affected identification with the Italian state in Trieste; however, sporadic expressions of national patriotism also revealed the endurance nationalist rhetoric within the Triestine population. In such a context, the Christian Democratic Party in Trieste experienced a significant change in its political elite and gradually opened the door to coalition with the Social Democrats. Despite this, Trieste's economic decline remained a powerful political tool that was used by local extremist forces to weaken popular support for both local Christian Democrats and the central government.

In the early 1960s, as mentioned, the short-lived center-right coalition government became object of widespread popular protests at the national level which led to its resignation. From this moment, the Christian Democrats' support for a center-left coalition and a policy of Adriatic détente met increasing support across the country yet was opposed by significant segments of the Triestine population. ${ }^{165}$ In the Adriatic city, nationalists and conservatives read the process of political normalization with Yugoslavia as well as the establishment of the autonomous region as decisive steps toward the definitive renunciation of Italian sovereignty over the ex-zone B. Indeed, both the reaffirmation of Italian territorial claims and the defense of Italian culture and language inside Trieste and its territory had long symbolized the government's commitment to the Italian identity of

\footnotetext{
${ }^{163}$ ACS, PCM, Ufficio Consigliere Diplomatico, B.27, Fasc. E47 Jugoslavia,” Visita del Vice Presidente del Consiglio Esecutivo della Repubblica Popolare Federativa di Jugoslavia Rankovic a Presidente Fanfani,” June 13-14, 1962.

${ }^{164}$ Fanfani remembered Rankovic as a very cunny host whose behavior well reflected the current status of the relations between the Adriatic neighbors, leaning toward openness yet anchored to mutual suspicion. ASR, Sezione IV, Fanfani Diari, June 15, 1962.

${ }^{165}$ From 1961, the inclusion of the Socialist Party within a Christian Democratic-led coalition government marked the end of political centrism and was furher agevolated by the approval of the Catholic Church, the new Kennedy's administration, and key publicly funded companies such as ENI and IRI. See Giuseppe Tamburrano, Storia e cronaca del centro-sinistra (Milano: Feltrinelli Editore, 1971).
} 
the border. The post-1954 experience of both the Italian residents of the ex-zone B and its émigrés magnificently exemplified the complexity of this issue for the Italian government.

\section{Forgotten and Unwelcome "Brothers": the Italians of the ex-zone B}

After 1954, while claiming Italian territorial sovereignty over the ex-zone B and attempting to restore the Triestine economy, the Italian government had to cope with a set of problems pertaining to the Italian citizens of the ex-zone B. Among them, the problem of the Italian soldiers still detained in Yugoslav camps or the judicial persecution against the Italian residents still living in the ex-zone B adversely affected local views of the restored Italian administration in Trieste.

Critics argued that not only did the government sign the London agreements without gaining from Tito's regime the release of Italian citizens from the Yugoslav camps, but in doing so it also contradicted the principles of Christian justice and solidarity. ${ }^{166}$ Only in 1955 , due to rising pressure from both public opinion and Istrian associations, the Italian and Yugoslav governments began negotiations for the release and exchange of prisoners. Yet by 1956 about 1,700 out of 3,000 detainees were still being held in Yugoslav camps.

Political considerations, however, delayed a quick resolution of the issue and persuaded Italian representatives to omit the problem from meetings with their Yugoslav counterparts. The government decided instead to release Yugoslav citizens in exchange for the liberation of Italian citizens who had been detained for supporting Italian claims over the disputed border. The sluggish pace of diplomacy, which strongly contrasted with the ratification of numerous Italian and Yugoslav commercial agreements, exacerbated feelings of abandonment among the families of the prisoners. $^{167}$

Similarly, the expulsion of Italian citizens from the Yugoslav territory for political reasons enhanced a sense of impotence among the residents of the ex-zone B who proved increasingly

\footnotetext{
${ }^{166} \mathrm{UZC}$, Sezione IV, Busta 6, Folder scambio detenuti politici tra Italia e Jugoslavia, "Letter from father Anselmo Sartori to Ministry of Foreign Affairs," December 5, 1954.

${ }^{167}$ UZC, Sezione IV, Busta 6, Folder liberazione detenuti italiani in Jugoslavia e Jugoslavi in Italia, "Note PCM," February 7, 1957.
} 
disillusioned about Rome's inability to defend their interests. ${ }^{168}$ These views were further strengthened by the arbitrary conviction of Italian citizens for espionage or their brutal mistreatment and arrest while visiting the ex-zone B. Their experiences often resulted in "physical persecution, forced confessions and months of jail." ${ }^{, 169}$ In response to these cases of arbitrary violence, the Italian Ministry of Foreign Affairs urged the national government to retaliate by expelling Yugoslav citizens who had displayed anti-Italian sentiments; the national government, however, fearing that such an action would produce diplomatic tension, decided instead to expel Yugoslav citizens who had been condemned for threats to the public order. This measure applied to all cities but Trieste, a decision that significantly restricted its effectiveness. ${ }^{170}$ The disagreements between the Ministry of Foreign Affairs and the Prime Minister's office highlighted the ambiguous attitudes of an Italian government which pursued the defense of only the Italian interests that did not jeopardize the new friendly relationship with Tito’s regime.

In addition, the perceived impunity of arbitrary Yugoslav decisions corroborated the image of an Italian state seemingly weak and indifferent to its citizens' needs across the border. In his speech commemorating World War One hero Nazario Sauro, Bishop Antonio Santin commented on the expulsion of Italians from the region and referred to the Italian state as "impotent before Yugoslav injustice and violence." 171 In response, the Italian Embassy in Belgrade firmly protested to the Holy See which promised to control Santin's public speeches. Papal diplomats agreed that the Istrian bishop's comments were indeed detrimental to both the Italian state and the Vatican which was already experiencing extreme political tension with Tito's regime.

Émigré associations, especially, manifested their concern for the Italians under Yugoslav administration. Among them, the "Unione Istriani” (Istrian Union, UI), founded after 1954 by

\footnotetext{
${ }^{168}$ UZC, Fondo Jugoslavia e Varie, Folder italiani deportati in Jugoslavia, "Confidential MAE to PCM, Letter from the President of the Families' Association Deported in Yugoslavia to President of Council," November 1, 1959.

${ }^{169}$ UZC, Fondo Jugoslavia e Varie, Busta 12, Vol. II, Folder soprusi delle autorità iugoslave ai danni di cittadini italiani in transito per la Jugoslavia, "CGGTT to PCM, connazionale Giorgio Umberto denuncia maltrattamenti," July 21, 1958. ${ }^{170}$ UZC, Sezione IV, Busta 81, Folder espulsione di connazionali dalla Jugoslavia, "Secret MAE to PCM," July 18, 1957.

${ }^{171}$ AST, Fondo CGGTT, Pacco 6, Fasc. 7/9, Curia Vescovile, "MAE to Palamara," July 30, 1957.
} 
dissidents of the C.L.N. Istria, called for the revision of both the Peace Treaty and the London Memorandum. ${ }^{172}$ In a letter to the Minister of Foreign Affairs Giuseppe Pella, its President, Sardos Albertini, reported the continuous violations to Italian minority rights which made any further concessions to the Slovenes of Trieste unfeasible. ${ }^{173}$ Likewise, the "Lega Nazionale" (National League) also carefully monitored the conditions of the Italian minority of the ex-zone B and in its correspondence with the Consulate of Capodistria echoed the U.I.'s position. ${ }^{174}$

Although the mistreatment of Italian citizens in the ex-zone B fueled local apprehension in Trieste, the central government only responded to the arbitrary behavior of the Yugoslav government in moderation. At the same time, however, Rome also firmly sought to remove any opposition to Italian rule inside Trieste. This process intertwined with the mass emigration from the city and between 1954 and 1961about 20,000 people emigrated from Trieste to Australia, a phenomenon that contradicted the demographic growth of the rest of the country. ${ }^{175}$

The high demands for specialized manpower, loose rules on immigration, and the presence of a significant community of Julian Venetians, however, only partially explains why about $10 \%$ of the Triestine community moved to Australia. In examining this issue, Gianfranco Cresciani argues that the volatile local political situation and wave of nationalism that characterized post-1954 Trieste encouraged those who had been lukewarm in their support of a pro-Italian solution to the "Trieste question" to leave. ${ }^{176}$ Among the émigrés were also those who had given proof of Italian patriotic sentiments but had been forced to leave for economic reasons. ${ }^{177}$ Mass emigration particularly affected representatives of the Independence Front, former members of the Allied administration, and significant personalities of the local Slovene community. Despite this, some segments of the Triestine community criticized the central government for the mild purge of Italian

\footnotetext{
${ }^{172}$ ACS, MI, Dipartimento della Pubblica Sicurezza, Cat.G, Associazioni, 1944-1986, B.363, Folder Unione degli Istriani.

${ }^{173}$ AUI, 1954-1967, Busta 5, Folder IV/8, "Albertini to Pella," February 4, 1958.

${ }^{174}$ ALN, Segreteria Politica, Folder 1961/1, "Letter Consul to Secretary LN," March 23, 1959.

${ }^{175}$ Pupo (2003), 225.

${ }^{176}$ See Gianfranco Cresciani. Trieste Goes to Australia (Lindfield, NSW: Padana Press, 2011).

${ }^{177}$ AST, Fondo CGGTT, Pacco 38, fasc.4/18, Emigrazione in Australia, "MAE to PCM," July 5, 1955.
} 
employees who had previously opposed a pro-Italian solution to the Triestine problem. The popular chant "Fracassi and Vitelli's good times are over, now begins Palamara's bitter time" expressed popular nostalgia for the local Italian Prefects of the immediate post-war years, a time in which the struggle for Trieste's "Italianità" indisputably drove the political strategy of the Italian state toward the border. ${ }^{178}$

These criticisms, however, proved ineffective. After 1954, indeed, in a context of heightened patriotic zeal and socio-political antagonism, about 6,000 individuals who were former employees of the Allied Military Government were accused of being "independent and notoriously anti-Italian," and became targets of both public resentment and state discrimination. ${ }^{179}$ In particular, Italian citizens who were former AMG employees encountered a set of bureaucratic procedures and legislative provisions that adversely affected the pace of their reallocation. These difficulties ultimately fueled local anger and disappointment among those who had firmly supported an independent Trieste and continued to support the Independence Movement. ${ }^{180}$

Above all, the new local Italian authorities looked with deep suspicion upon the Italian members of the former Allied police, the Julian police force. ${ }^{181}$ After the approval of the London Memorandum, about 35 former members of its most infamous division, the "Nucleo Mobile," left immediately for England with their families as they were locally perceived as mainly responsible for the November 1953 deaths. ${ }^{182}$ By 1956, another two thousand members of the Julian police were encouraged to emigrate. ${ }^{183}$ Italian state agents in Trieste informed the central government that, while travelling to the ex-zone B to visit their relatives, Italian and Slav members of the Julian civil police were approached by agents of the Yugoslav secret police and, under the threat of retaliation

\footnotetext{
${ }^{178}$ ACS, Partiti Politici, Schedario, 1944-1966, Divisione Affari Riservati, 1951-1953, B.36 (cat.O10), "Folder servizi informativi jugoslavi in Italia," December 2, 1954.

${ }^{179}$ UZC, Sezione II, Fondo Trieste, Busta 92, Vol. II, Folder sindacato dipendenti dell'ex-GMA, "Note from CGGTT to PCM," October 29, 1955.

${ }^{180}$ UZC, Fondo Contributi, Sussidi e Spese, Busta 5, Folder Capitano Sabino Manzoni.

${ }^{181}$ UZC, Sezione IV, Busta 10, Folder teatro sloveno di Trieste, "MAE to PCM, sospensione spettacolo del Teatro Nazionale Sloveno," April 23, 1957.

${ }^{182}$ UZC, Sezione II, Fondo Trieste, Busta 25, Vol. II, Folder emigrazione di ex-appartenenti alla Polizia Civile, "MAE to PCM," November 8, 1954.

${ }^{183}$ UZC, Sezione II, Fondo Trieste, Busta 25, Vol. II, Folder emigrazione di ex-appartenenti alla Polizia Civile,

"Situazione nel Territorio di Trieste," February 25, 1955.
} 
against their families, were forced to pass confidential political and military information. ${ }^{184}$ To safeguard Italian security without fomenting diplomatic tension, Governor Palamara decided to deny travel permits to members of the Julian police or ex-members of the AMG whom, while still working for the new Italian administration, often travelled to the ex-zone B. ${ }^{185}$

In a context marked by widespread governmental and popular suspicion toward former detractors of a pro-Italian solution to the Triestine problem, the central government also had to cope with the massive migration of Italian residents from the Istrian region. ${ }^{186}$ Although these émigrés were protected by specific clauses of the London Memorandum, the contrasting democratic and communist nature of the Italian and Yugoslav systems made the enforcement of its working principle, reciprocity, unfeasible. Thus, the Italian government faced again the criticism of those who pointed to its lack of firmness in defending Italian rights in the ex-zone B or its excessive concessions to the Slovene minority in Trieste. ${ }^{187}$ As it happened in the past, Rome tried to respond to local criticism without incurring accusations of discrimination by the Yugoslav authorities. For example, in 1955 Slovene residents of Trieste who acted for the Slovene theatre were accused of being part of the local pro-Titoist network. The national government, fearing possible Yugoslav retaliation, decided to restrict the mobility of the actors between Trieste and the ex-zone B rather than proceeding with their expulsion. ${ }^{188}$

Meanwhile, the Italian government repeatedly protested to the Yugoslav administration for its unwillingness to provide adequate infrastructure and administrative autonomy for the Italian schools in the ex-zone B. ${ }^{189}$ At the same time, however, the central government also decided to reduce its financial support to Italian associations of the ex-zone B, which had traditionally assisted

\footnotetext{
${ }^{184}$ UZC, Sezione II, Fondo Trieste, Busta 25, Vol. II, "Riservatissima from Palamara to Presidenza del Consiglio," January 7, 1957.

${ }^{185}$ UZC, Sezione II, Fondo Trieste, Busta 25, Vol. II, "Riservata from Palamara to Presidenza del Consiglio," March 26, 1957.

${ }^{186}$ Petacco, 135 .

${ }^{187}$ Sidra, “Il Bilancio del Memorandum dopo un anno di delusioni," Difesa Adriatica (October 8-15, 1955).

${ }^{188}$ UZC, Sezione IV, Busta 10, Folder teatro Sloveno di Trieste, "Note PCM," October 12, 1955.

${ }^{189}$ UZC, Sezione II, Trieste, Busta 44, Vol.I, Folder situazione scolastica nell'ex-zona B del TLT, "CGGTT to PCM, scuole italiane in zona B," October 29, 1958.
} 
local Italian teachers and students by providing didactic material. ${ }^{190}$ Although the activity of these associations had been significantly constrained by the Istrian exodus and the massive purge of Italian teachers, representatives of these associations argued that, in abandoning the remaining personnel of zone B, Rome was further weakening the Italian identity of the border. ${ }^{191}$ From their perspective, the closure of the last Italian magazine of ex-zone B, La Nostra Lotta, became symbolic of the continuous process of de-Italianization of the Istrian region. ${ }^{192}$

Il Piccolo, the main Triestine newspaper, stressed the limits of the Italian state and the feeling of abandonment that pervaded the Italians of the ex-zone B. In its views, the London Memorandum represented the final step in creating an "iron border." ${ }^{193}$ Eager to prove its commitment to the Italian residents still living in the ex-zone B and to show its support of Italian culture and language, the government exported Italian newspapers and journals to the area. ${ }^{194}$ Such initiatives, however, only had a limited impact on the morale of the émigrés who, within local public discourse, were portrayed as a living proof of the "unique, natural, and geographic reality" that made of Trieste and Istria a single region. ${ }^{195}$

As mentioned above, emigré organizations themselves were also directly affected by Rome's increasing accommodation to the principle of peaceful co-existence with the Yugoslav neighbor, which coincided with a partial reduction in state financial support to associations such as the Istrian C.L.N., the Istrian Union, and the National Association Venetia Julia and Dalmatia (ANVGD). After 1953, for instance, the national government repeatedly dismissed requests for support from

\footnotetext{
${ }^{190}$ UZC, Sezione II, Fondo Trieste, Busta 65, Vol. I, Folder esodo dalla zona B del personale insegnante, "Confidential E.I.S.E. to PCM," October 23, 1954.

${ }^{191}$ UZC, Sezione II, Fondo Trieste, Folder E.I.S.E., Busta 65, Vol. I, "Note from Palamara to PCM and Ministry of Education," January 26 and May 25, 1955.

${ }^{192}$ UZC, Sezione II, Fondo FVG, Fiume, Busta 1, 5/1, Fasc.16, "Correspondence from the Commissariato Generale del Governo per il Territorio di Trieste (CGGTT) to Presidenza del Consiglio dei Ministri (PCM)," July 19, 1956.

193“"Dobbiamo ricostruire l'Istria nel corpo vivo della nazione," Il Piccolo (June 1, 1955).

${ }^{194}$ UZC, Sezione II, Trieste, Busta 43, Folder giornali italiani in Zona B, "Importazione giornali italiani nella ex-zona B," October 13, 1956.

${ }^{195}$ This definition that stressed the unnatural division of Trieste and its Istrian region was coined by writer and intellectual Gianni Stuparich. UZC, Sezione IV, Busta 82, Folder Casa Fraternità Istriana.
} 
the Triestine Committee of the ANVGD. ${ }^{196}$ This decision had responded to the protests of the Istrian C.L.N. over the leading role that fascists like Libero Sauro and Bruno Coceani had in the association. ${ }^{197}$ Consequently, the Triestine Committee of the ANVGD was only able to resume its activities in the city in $1956 ;{ }^{198}$ however, even then, the role of Maurizio Mandel, one of its leaders and a former member of the fascist black shirts, continued to fuel suspicion and distrust toward the association. ${ }^{199}$ Following Mandel's exclusion from its Presidency in 1957, ANVGD began to increasingly conform to the progressive views of the central government and as a consequence would come to benefit again from its financial support. ${ }^{200}$

In 1956, members of the Istrian C.L.N. elaborated a detailed memorandum which highlighted the detrimental effect that the presence of fascist personalities among the Istrian Union had on the image and reputation of the émigrés, who were publicly portrayed as sentimental nationalists. ${ }^{201}$ The Istrian Union rejected these accusations by pointing to the democratic, republican, liberal, social democrat and Catholic affiliations of its leadership, yet these counterclaims remained largely unheard by the central government. ${ }^{202}$ The government, completely disregarding the moderate views of the C.L.N. and its pivotal role in "educating the émigrés to the values of democracy and keeping them away from extremist political formations," also decided to reduce financial contributions to this association. ${ }^{203}$ As these cases show, the government cut financial support for émigré organizations that had strongly supported a pro-Italian solution to the border dispute and the presence of former fascists within the émigré associative network also significantly discredited its entire community.

\footnotetext{
${ }^{196}$ UZC, Sezione II, Fondo Comitati e Associazioni, Busta 10, Folder ANVGD Gorizia, "Contributions 1950-1959," February 4, 1960.

${ }^{197}$ ASL, Fondo Democrazia Cristiana, Segreteria Politica, Fanfani, Sc. 59, f.1, "Fragiacomo to President of Republic Einaudi," December 17, 1954.

${ }^{198}$ UZC, Sezione II, Fondo Comitati e Associazioni, Busta 11, Vol.I, Folder ANVGD Comitato Provinciale di Trieste, "Palamara to PCM," June 15, 1956.

${ }^{199}$ ACS, MI, Divisione Affari Riservati, 1957-1960, B. 238, Folder Fronte Giuliano di Resistenza e Ricostruzione proVenezia Giulia, fasc.1.

${ }^{200}$ Archivio Fondazione Ugo Spirito (AUS), Fondo Luigi Papo, Busta 36, Fasc. ANII polemiche con CLN, " Note to Mandel," August 10, 1962.

${ }^{201}$ AUI, 1954-1967,Busta 5, Folder III/2, "Memorandum C.L.N.," November 28, 1956.

${ }^{202}$ AUI, 1954-1967, Busta 5, Folder III/7, "Unione Istriani to DC, PRI, PLI, PSDI," November 30, 1956.

${ }^{203}$ UZC, Sezione II,Trieste, Busta 70, Folder Comitato Nazionale di Liberazione Istria, "CGGTT to PCM, C.L.N. Istria," March 22, 1960.
} 
Indeed, Yugoslav propaganda continued to portray Italian mass migration as a voluntary phenomenon which arose from the unwillingness of the Italians to concede their traditional position as the dominant nationality. ${ }^{204}$ Local associations like the C.L.N and relevant political and religious figures, among them Bishop Santin, vigorously opposed Yugoslav claims. ${ }^{205}$ Despite the stereotype of the émigrés as intransigent fascists promoted by Yugoslav propaganda, its majority did not in fact harbor extremist sentiments. Local authorities in Trieste reported that the new wave of incoming émigrés consisted of individuals who had escaped to avoid rising fiscal pressure and Yugoslav military service rather than for clear sentiments of "Italianità." ${ }^{206}$ Similarly, in an interesting letter to the leader of the Italian Socialist Party, Pietro Nenni, a group of informants from the zone B stressed that about $70 \%$ of the Italian émigrés were members of the small and middle entrepreneurial class. They left in order to exercise their right to private property rather than because of their deep nationalism. ${ }^{207}$

Most yet not all of the Italians, however, had decided to leave from the Istrian region. Those who decided to stay were increasingly disillusioned by the apathy of the Italian government and saw the Consulate in Capodistria as the single Italian institution able to defend their rights in the region. ${ }^{208}$ In addition, segments of the Italian community in Yugoslavia had also embraced Yugoslav socialism. ${ }^{209}$ About 20,000 Italians participated in the Yugoslav elections of 1958 and members of the Italian community were elected to its federal Parliament. According to the Istrian C.L.N. these representatives were Yugoslav nationalists of Italian ethnicity who misrepresented the political orientations of the community surviving in Istria and Fiume. Interestingly enough, centerleft journals noted that, as a consequence of the forced expatriation of its ruling class, the local

\footnotetext{
${ }^{204}$ UZC, Sezione II, Fondo Trieste, Busta 44, Vol. I, Folder provvedimenti presi dalle autorità jugoslave nei territori ceduti per effetto del Trattato di Pace e dopo gli Accordi di Londra, "Conferenza annuale della Lega dei Comunisti nel Distretto di Capodistria. Dichiarazioni sull'esodo del gruppo etnico italiano," January 28, 1956.

${ }^{205}$ UZC, Sezione IV, Busta 19, Folder assistenza ai profughi, "Santin to Secretary of State Scalfaro," March 22, 1955.

${ }^{206}$ UZC, Sezione IV, Busta 19, Folder Movimento Indipendentista filo-italiano, "Palamara to PCM," August $18,1956$.

${ }^{207}$ ACS, Carte Moro, Atti Personali 1964-1977, Busta 177, Fasc. Fenoaltea, "Confidential note to Nenni," January 12, 1956.

${ }^{208}$ UZC, Fondo Jugosalvia e Varie, Busta 16, Vol. II, Folder elezioni politiche in Istria, "Letter from President of C.L.N. Istria Fragiacomo to Ministry of Foreign Affairs Pella," April 2, 1958.

${ }^{209}$ Monzali, ed. Botta and Garzia, 48.
} 
Italian community in Yugoslavia had become politically insignificant and its proximity to Trieste had become more an ethnic barrier than a bridge. ${ }^{210}$

Thus, to assist about forty thousand incoming émigrés from the Istrian region, the central government established a special fund of five billion lira between 1954 and $1956 .^{211}$ The housing program faced numerous delays and flaws, however, exacerbating popular disillusionment toward the Italian administration. ${ }^{212}$ The absence of a specific office to better coordinate the efforts of both Roman and Triestine authorities, indeed, greatly reduced the responsiveness of the Italian state to mass immigration. ${ }^{213}$ Palamara noted that in a city with 20,000 unemployed, only a third of the émigrés could find jobs and their survival depended on the assistance of local associations which proved insufficient. The only possible solution for the incoming émigrés was state support to "grant them the house and job for which they escaped to Italy," which would prevent their social degradation and reduce their support for extreme political parties. ${ }^{214}$

These measures aimed to ease the socio-political re-integration of the incoming émigrés, a problem that was further aggravated by the fact that some of them were former members of the Yugoslav police, had manifested anti-Italian feelings and had also persecuted their fellow residents in the ex-zone B. The local authorities labeled these émigrés as "undesirable" and, in order to minimize tension with their former victims inside the Triestine refugee camps, suggested their transfer to other cities. ${ }^{215}$ The Ministry of Interior, concerned about possible socio-political tension deriving from the presence of these émigrés in local communities outside Trieste, initially leaned toward the creation of separate camps in the city. ${ }^{216}$ Ultimately, the prospective return of these

\footnotetext{
${ }^{210}$ Guido Botteri and Giorgio Cesare, "Gli italiani in Jugoslavia," Trieste (July-August, 1961).

${ }^{211}$ UZC, Sezione IV, Busta 19, Folder assistenza ai profughi, "Scalfaro to Santin," April 4, 1955.

${ }^{212}$ UZC, Sezione II, Trieste, Busta 53, Vol.I, Folder estensione a Trieste dei provvedimenti legislativi sul problema edilizio, "Palamara to PCM," March 12, 1955.

${ }^{213}$ UZC, Sezione IV, Busta 18, Folder esodo connazionali della zona B sistemazione a Trieste, "Note of Palamara," March 7, 1956.

${ }^{214}$ UZC, Sezione IV, Busta 18, Folder esodo connazionali della zona B sistemazione a Trieste, "Palamara to PCM," September 1, 1956.

${ }^{215}$ About 50 people with 137 relatives were accused of collaborationism with the Yugosalv regime. UZC, Sezione IV, Busta 18, Folder profughi indesiderabili della zona B, "Confidential C.L.N. Istria to CGGTT and PCM," September 23, 1955.

${ }^{216}$ UZC, Sezione IV, Busta 18, Folder profughi indesiderabili della zona B, "MI to PCM," March 2, 1956.
} 
"undesirable" people to Yugoslavia and its beneficial effect on Trieste persuaded the central government to embrace Governor Palamara's proposal and temporarily remove these émigrés from Trieste. ${ }^{217}$ This measure, while aiming to minimize social tension inside Trieste, also responded to local grievances and émigrés' complaints about the unfair living conditions of the camps. ${ }^{218}$ Local neo-irredentist associations such as the National League for example, had repeatedly claimed that the mistreatment of the incoming émigrés weakened the image of Italy as a symbol of civilization and justice. Upholding this image could ultimately prove the stark contrast between a democratic Italy and an oppressive Yugoslavia and finally equate the struggle for the Italian claims toward the border to the struggle for freedom. ${ }^{219}$

This fact took specific importance in the early 1960s when the number of émigrés in multiple camps inside and outside Trieste reached 12,000, a symbol of the government's failure to respond the needs of the incoming émigrés who had left the Yugoslav territories. ${ }^{220}$ Their cause found support among ex-combatant associations, World War One veterans, and local right-wing formations who established committees for the defense of national unity and irredentism. ${ }^{221}$ The propaganda of these groups, which preyed on the disillusionment and anger of the refugees still living in the city's camps, weakened popular support for the Italian government and threatened the process of reconciliation between Italian and Slovene segments of the local population. For example, the youth irredentist and neo-fascist association "Giovane Italia" (Italian Youth) posted two anti-Slav flyers that invited the Triestine community to oppose the rising threat of pan-Slavism inside a Triestine refugee camp. ${ }^{222}$ The flyers depicted the government's approval for a Slovene bank and the prospective legislative provisions to introduce judicial and administrative bilinguism as a clear sign of the increasing weakness of the Italian state.

\footnotetext{
${ }^{217}$ UZC, Sezione IV, Busta 18, Folder profughi indesiderabili della zona B, "PCM to MI and CGGTT," May 11, 1956.

${ }^{218}$ UZC, Sezione II, Trieste, Busta 56, Vol.II, Folder gestione campi profughi da parte dell'A.S.I. "Letter from a refugee to Ministry of Interior Tambroni," September 12, 1957.

${ }^{219}$ ALN, Segreteria Politica, Folder 1955/1956 V, "Telegram Harabaglia to Gronchi," August , 1956.

${ }^{220}$ Valdevit (2004), 80.

${ }^{221}$ AUS, Fondo Luigi Papo, Busta 33, Fasc. Associazione Nazionale Volontari di Guerra, "Pescosolido to Papo," April 23, 1959.

${ }^{222}$ UZC, Sezione II, Fondo Trieste, Busta 56, Vol.II, Folder gestione campi profughi da parte dell'A.S.I. "CGGTT to PCM, manifestini di protesta affissi in una baracca del campo profughi di Padriciano," December 8, 1959.
} 
The problem of the émigrés, but also the accommodating behavior of the Christian Democrats toward the local Slovene minority and its gradual openness toward the political parties of the center-left, became central to the anti-governmental propaganda of right-wing groups. In response, the central government significantly cut contributions to local ex-combatant, monarchic and patriotic associations, a decision that well symbolized the new Christian Democratic strategy toward the border, and, more interestingly, also aligned with former cuts in the contributions to the émigré associations. ${ }^{223}$

These associations, already weakened by the government's strategy, also experienced rising internal division. In an exchange of letters, Piero Almerigogna, a prominent political figure of the Istrian émigrés, wrote to the Julian-Dalmatian intellectual Luigi Papo that "the local Christian Democratic Party does not oppose the social-democratic orientations of the Istrian CLN; therefore, for people like us who identify themselves with right-wing political formations and do not have any political influence over the local Christian Democrats, it is very difficult to challenge the leftist views of the CLN." 224 This statement confirmed the divergent views of the Istrian Union and the CLN. Indeed, while the CLN proved supportive of the gradual Christian Democrats' shift toward the coalition experiment of the center-left, Almerigogna, reflecting the sentiments of the majority of the émigrés, firmly opposed this change on behalf of the Istrian Union and hoped to re-orient the Istrian community toward the right. The danger of an extremist turn toward the right was also confirmed by Libero Sauro, the newly elected President of the ANVGD. In his letter to Minister of Interior Mario Scelba, Sauro stated that in order to strengthen the association's democratic orientations and defeat the propaganda of its rightist fringe, it urgently needed economic support from the central government. ${ }^{225}$

\footnotetext{
${ }^{223}$ ASL, Fondo Democrazia Cristiana, Segreteria Politica, Moro, corrispondenza con organizzazioni Varie, Sc.156, Fasc.34, "Rapporto segreto circa situazione amministrativa," January 29, 1960.

${ }^{224}$ AUS, Fondo Luigi Papo, Busta 10, Fasc. Almerigogna Piero, "Letter to Papo," September 25, 1958.

${ }^{225}$ ASL, Fondo Democrazia Cristiana, Segreteria Politica, Moro, corrispondenza con gli organi periferici, Sc. 137, S.fasc. 2, "Sauro to Scelba," October 23, 1961.
} 
While claiming its intention to strengthen the democratic views of its members, the ANVGD increasingly feared that the new progressive views of the Christian Democrats would also affect the government's foreign policy and induce Rome to acquiesce to Yugoslav pressure for a formal definitive settlement of the eastern border. In response, the associations, together with the Istrian Union established the "Centro di Vigilanza Nazionale" (Committee of National Defense) to oppose widespread misinformation about the geo-political situation of the Istrian region and preserve Italian territorial claims over the ex-zone B. ${ }^{226}$ Although the leadership of the émigré association and the majority of its members generally showed Christian Democratic political orientations, their views toward the ex-zone B remained substantially unchanged and continued to uphold the preservation of Italian territorial claims over the Istrian region.

Thus, Slovene authorities in Yugoslavia continued to read the initiatives of the émigrés through the lenses of classic Italian nationalism and labeled them as "irredentist and revanchist." 227 In such fashion the Slovenes understood the "émigrés day," a celebration arranged in Trieste by the Istrian émigré associations to remember the mass Adriatic exodus. ${ }^{228}$ In response to these criticisms, Gianni Bartoli, Trieste's former mayor and a member of the executive committee of the Refugees National Association for Julian and Dalmatians, celebrated the cosmopolitan tradition of Trieste as an antidote to past forms of nationalism. He claimed the unbreakable unity between Trieste and Istria in the phrase "Trieste without Istria stagnates and Istria without Trieste is dying.",229 Bartoli's statement well summarized the leading views that dominated both the Triestine population and its Istrian émigrés who still viewed the city as the promoter of Italian cultural traditions and the bridge to the Istrian region, an integral part of Italy's imagined community temporarily located outside its physical border.

\footnotetext{
${ }^{226}$ Baroni, 107-146.

${ }^{227}$ ACS, PCM, Ufficio Consigliere Diplomatico, Busta 24, Fasc. E3, Profughi, Sfasc. Giornata del Profugo, "Letter from MAE to Political Adviser Sensi," March 19, 1960.

228“"La giornata del profugo: ridare il sorriso a chi l'ha perduto," Il Piccolo (March 27, 1960).

${ }^{229}$ AST, Fondo Gianni Bartoli, Busta 4, "Discorsi," 1960.
} 
Although local demonstrations of émigrés from Istria and Dalmatia were generally peaceful, sporadic damage to monuments celebrating Yugoslav resistance and anti-Slav graffiti such as "Fora i s'ciavi!" (Go away Slavs!) certainly revealed the strength of revanchist attitudes among fringes of the local Italian population. ${ }^{230}$ In commenting on these sporadic episodes of intolerance, Giorgio Tombesi, one of the most intransigent detractors of the Osimo Treaty and leading figures of the Triestine Christian Democratic Party, argued that the majority of the population did not harbor feelings of hostility towards the Slovene minority. Tombesi claimed that Italians and Slovenes had indeed coexisted for centuries and interacted in Trieste's urban and peripheral communities. In postwar Trieste, local hostility took a specific political rather than ethnic meaning and was directed toward the Yugoslav regime and its local supporters, who were generally perceived as responsible for the unforgivable experiences of the "foibe. ${ }^{231}$ In the 1960s and early 1970s, such an issue repeatedly re-emerged in local public discourse to oppose both the government's concessions to the local Slovene minority and, especially, the formal recognition of Yugoslav sovereignty of the exzone $\mathrm{B}$, an issue that is explored in-depth in the last chapter of this dissertation.

As discussed so far, after 1954 the Italian government's efforts to guarantee the rights of the Italian minority of the ex-zone B had to increasingly conform to the goal of diplomatic normalization with Tito's Yugoslavia. ${ }^{232}$ While searching for a new Adriatic partnership, however, the Italian government also intended to consolidate popular support in Trieste and welcomed the mass emigration from the city of those members of its local population who had opposed a proItalian solution to the Triestine problem. Furthermore, while coping with the city's transition from an Allied to Italian administration, the Italian state also had to respond to the massive Istrian immigration to and beyond Trieste. The state's inability to facilitate the social integration of the incoming émigrés and protect both the property as well as the rights of Italians still living in the exzone B boosted local criticism of the central government.

\footnotetext{
${ }^{230}$ UZC, Sezione IV, Busta 50, Folder situazione politica generale del Territorio di Trieste, "Confidential CGGTT to PCM," February 28, 1961.

${ }^{231}$ Tombesi's Interview, March 2012.

${ }^{232}$ ASL, Fondo Mario Scelba, Versamento II, Corrispondenza, B.17, f.199, "Scalfaro to Scelba,” February 8, 1961.
} 
By the late 1950s, not only central but also local authorities became objects of widespread popular criticism. The gradual political shift of the Christian Democrats toward governmental coalition of leftist orientations also determined the cut of financial support to the émigré associational network, ultimately enhancing the concerns of Trieste and its Istrian émigrés. This political change which was read as a threat to the Italian identity of the city was also accompanied by increasing tension between the more moderate and extremist segments of the émigré associations as well as sporadic expressions of anti-Slav sentiments.

Thus, in the late 1950s and early 1960s, the strategy of both the Italian central and local authorities toward the émigrés and their associations in the ex-zone B significantly changed. Despite this, the strategy of the Italian government toward Trieste was not radically altered after the signature of the London Memorandum. As explored in the next section, the central authorities continued to significantly support local propaganda of "Italianità" in Trieste through the Office of Border Zones (UZC), especially before the Christian Democratic opening to the Socialist Party of the early 1960 s. $^{233}$

\section{Making the Border Italian: New Wine in Old Bottles}

After 1954 the Italian government abandoned its goal to reincorporate the Istrian region within the state's borders despite its official rhetoric. Popular support for the Italian administration depended more on the ability of the Italian state to extend the Italian "economic miracle" to Trieste, safeguard the rights of the Italian residents of the ex-zone B, assist the Istrian émigrés, and preserve Italian language and culture across the border rather than extend Italian sovereignty to the ex-zone B. ${ }^{234}$ As a consequence, the revision of the demarcation line remained a possible yet remote political option that languished amidst commercial agreements and diplomatic negotiations.

\footnotetext{
${ }^{233}$ Baroni, 153.

${ }^{234}$ These new understandings strongly related to Mazzinian views of homeland not simply as an entity consiting of common land or language but also as an abstract space underscoring values of brotherhood and solidarity which were expressed in political regimes maximizing individual liberties. Alfredo Bottai, "La patria," Il Pensiero Mazziniano (August-September, 1957).
} 
Although the majority of Italians in Trieste proved more concerned about the status of the local economy than about the assertion of former Italian claims over the disputed border, the intransigent defense of the Italian identity of the city and anti-Titoist feelings fueled phenomena of ethno-political conflict, negatively affecting the pace of democratization of post-war Trieste. ${ }^{235}$ Thus, significant segments of the local population greatly criticized the Christian Democrats' move toward a center-left political coalition. These views found further support in the Catholic Church and its opposition to Yugoslav communism. In uninterruptedly supporting the unitary and indivisible character of the Triestine dioceses which extended over both Trieste and the ex-zone B, the Catholic Church implicitly upheld the fiction of Italian formal territorial rights over the ex-zone B. ${ }^{236}$

The central government, indeed, understood that Trieste and its Istrian émigrés were by no means willing to recognize Yugoslav sovereignty over the ex-zone B, at least in the short-term. Thus, the Italian government, eager to enhance local political support, unevenly granted significant financial contributions to a variety of associations with recreational, social, economic, cultural, or artistic goals. ${ }^{237}$ These contributions, officially recorded as expenses for "propaganda d'Italianità," were entrusted to the personnel of the Office of Border Zones (UZC), which after 1954, took the name of "Ufficio Regioni" (Office of Italian Regions).

From the beginning, however, the relations between this office and the local Christian Democrats were tense. The border office intended to appoint a bureaucrat who would continue its former nationalist policy and would be easily subjected to the political influences of Rome. Local Christian Democrats instead supported a politically autonomous figure who would better

\footnotetext{
${ }^{235}$ For an interesting work which examines the survival of rooted antagonistic ethnic stereotypes throughout the Adriatic border, see Moreno Zago, "Il confine ponte: la strategia," ed. Meyer and Pupo, 78-88.

${ }^{236}$ The Catholic Church actively supported the Italian identity of the former Free Territory of Trieste by means of its associational network, in particular the local Italian Catholic University Federation (F.U.C.I.) which also benefited from governmental contributions. Pressure from leading Catholic figures, among them Bishop Santin, played a crucial role to grants of financial support until 1970s. UZC, Sezione V, Dall'Ufficio per le Zone di Confine all'Ufficio Regioni Friuli Venezia Giulia, Busta 16, Folder Federazione Universitaria Cattolica (F.U.C.I.), "Contributions 1953-1970," 1970.

${ }^{237}$ UZC, Sezione V, Busta 24, Vol.II, Folder Trieste Circolo della Cultura e delle Arti, "Contributions 1949-1984."
} 
understand the city's needs and combat political independence sentiments among the population. ${ }^{238}$ The UZC eventually prevailed and, over time, continued to support associations whose alleged apolitical nature were a subterfuge to consolidate the Italian cultural and linguistic identity of Trieste and its territory, among them the "Dante Alighieri." ${ }^{239}$ Financial support for these associations often increased in proximity to local and national elections or patriotic celebrations. ${ }^{240}$

Thus, the central government, upon the suggestion of the UZC, allocated its funding to organizations based on their nature and political utility. Local associations purely giving assistance or those with educational goals generally experienced a gradual decrease in governmental contributions. ${ }^{241}$ The central authorities, instead, proved particularly willing to support cultural, excombatant, and youth associations of democratic and patriotic orientations. The Yugoslav government, for its part, continued to perceive patriotic and émigré associations as expressions of aggressive Italian irredentism which, it believed, ultimately aimed to remove the Slovene minority, figuratively portrayed as a "trnj v peti" (thorn stuck in the heel) of Trieste. ${ }^{242}$ These criticisms were also echoed within journals of leftist political orientations which claimed that right extremists and elements of the American intelligence community actively cooperated to support the anticommunist and pro-Atlantic foreign policy of the national government. ${ }^{243}$

After 1954, however, the central government firmly distanced itself from its nationalist tendencies of the past and, in Trieste, significantly reduced financial support to associations that had been compromised by political extremism. Not surprisingly, it expanded support for specific initiatives of the Christian Democrat party, among them the Political Economic Agency of Rome

\footnotetext{
${ }^{238}$ IRSML, Fondo Venezia Giulia, Busta 31, Confidential Note 2361, "Note of Carl Schiffrer on UZC and State Adviser Innocenti," Undated.

${ }^{239}$ This association promoted Italian culture and language by arranging linguistic courses, conferences, students' awards, libraries, and publications. UZC, Sezione V, Busta 26, Vol.I, Folder Società Nazionale Dante Alighieri, "Contributions 1946-1984."

${ }^{240}$ The contributions of the local government for charitable or patriotic initiatives to gymnastic, recreational, military, and Catholic associations significantly fluctuated between 1955 and 1963. UZC, Sezione IV, Folder Fondo a Disposizione del Commissario del Governo di Trieste, Busta 7, Vol. I and Vol. II.

${ }^{241}$ UZC, Sezione II, Trieste, Busta 33, Vol,II, Folder Trieste Villaggio del Fanciullo, "Note PCM," September 9, 1955.

${ }^{242}$ UZC, Sezione IV, Busta 23, Folder passaggio di poteri nel Territorio di Trieste, "Palamara to PCM, Confidential Information," October 25, 1955.

${ }^{243}$ Giancarlo Pajetta, "Le odierne organizzazioni fasciste, i loro legami nazionali e internazionali," Rinascita (March, 1955).
} 
(A.P.E.). The goal of this information agency was to support the policies of the central government through its propaganda of "Italianità." Its activities consisted of daily coordination with leading figures of the national Christian Democratic Party, among them Giulio Andreotti, and prominent journalists of the Christian democratic newspaper Il Popolo. ${ }^{244}$ The government also supported the Triestine cultural circles which ultimately aimed to promote the recovery and reintegration of the local economy within the national and European markets. Between 1957 and 1983, the central government supported these activities with significant amounts of money that peaked on the fiftieth anniversary of Trieste's national "redemption" in $1968 .{ }^{245}$

By contrast, the central government denied support to local associations that were politically irrelevant and dominated by radical nationalist orientations. ${ }^{246}$ The judgment of the central government was strongly affected by the reports of the UZC and especially the impressions provided by the local Governor Palamara. ${ }^{247}$ In one of such instances, Palamara's unfavorable views toward associations such as the Triestine branch of the Italian Nationalist Association resulted in the denial of all contributions from the central authorities. ${ }^{248}$ Indeed, the government proved willing to support the cultural Italian identity of the border by mobilizing local and national associations of democratic orientations yet looked with rising suspicion upon associations of nationalist and profascist orientations. Even among these, however, associations like the "Lega Dalmata" (Dalmatian League) had lost faith in a possible reintegration of the Dalmatian region inside Italian borders, while others reorganized under the leadership of both the neo-fascist and monarchic parties to uphold irredentist ambitions for Istria, Carnaro, and Dalmatia. ${ }^{249}$ Members of these associations

\footnotetext{
${ }^{244}$ UZC, Sezione IV, Busta 82, Vol.II, Folder Trieste, A.P.E., "PCM Note," July 21, 1959.

${ }^{245}$ UZC, Sezione V, Busta 24, Vol.I, Folder Trieste Circolo Studi Sociali "G. Toniolo," "Correspondence and Contributions 1957-1983."

${ }^{246}$ UZC, Sezione II, Trieste, Busta 92, Vol.II, Folder Associazione Caduti Feriti e Famiglie per la Causa Nazionale di Trieste, "Note from CGGTT to PCM," April 2, 1955.

${ }^{247}$ UZC, Sezione V, Busta 24, Vol.I, Folder Trieste Centro Studi Politici Economici e Sociali, "Correspondence 19581967."

${ }^{248}$ UZC, Sezione IV, Folder Associazione Nazionalista Italiana Trieste, "Presidency of Council to A.N.I.," October 20, 1959.

${ }^{249}$ ACS, MI, Divisione Affari Riservati, 1957-1960, B.101, Folder Gruppo Irredentistico Adriatico, "Report," March 23, 1955.
} 
were usually veterans who belonged to the neo-fascist movements and identified with the motto "God, Homeland, Family." 250

Not only the Italian government but also patriotic and democratic associations negatively perceived extremist groups that called for the territorial re-conquest of the territories that had been lost with the Paris Peace Treaty and were now under Yugoslav administration. ${ }^{251}$ For example, veteran associations such as the "Federazione Italiana Volontari della Libertà" (Italian Federation of Volunteers Freedom, FIVL), established in 1948 and counting approximately 100,000 members of Christian democratic orientations, called for state support in defense of Italian culture and language across the Triestine territory rather than its unlikely territorial reintegration. ${ }^{252}$ In its actions, the FIVL was strongly supported by the Italian Mazzinian Association and its journal Il Pensiero Mazziniano. ${ }^{253}$ These associations, which showed moderate nationalist attitudes, were positively perceived by the Italian government and, over time, received significant financial support. ${ }^{254}$ Among all them, the National League played a pivotal role in the preservation of both the Italian heritage of Trieste and its territory. ${ }^{255}$ Even though the diplomatic resolution of the Triestine question indisputably weakened the popularity of the association, it continued to defend Italian culture and language in the Adriatic while hoping for future revisions to the territorial provisions of the treaties signed by the Italian and Yugoslav governments. ${ }^{256}$ In promoting the "Italianità" of the border, the National League criticized the Paris Peace Treaty and its unfair territorial clauses which "stripped Italy of its lands across the Adriatic border." ${ }^{257}$ Its propaganda, supported by journals such as Difesa Adriatica (Adriatic Defense) or Arena di Pola (Pola Arena), reached both Italians at

\footnotetext{
${ }^{250}$ ACS, MI, Divisione Affari Riservati, 1957-1960, B.98, Folder Unione Nazionale Forze Indipendenti, "Programmatic Platform," January 17, 1956.

${ }^{251}$ ACS, MI, Divisione Affari Riservati, 1957-1960, B.167, Folder Compagnia Volontari Giuliani e Dalmati, "Note from Trieste Police Chief," May 13, 1966.

${ }^{252}$ ACS, MI, Dipartimento della Pubblica Sicurezza, Cat. G, Associazioni 1944-1986, B.23, FIVL, August $21,1962$.

${ }^{253}$ Among others, was conspicuously funded until 1978 and financial contributions significantly fluctuated overtime. UZC, Sezione V, Busta 9, Vol. II, Folder A.M.I., "Contributions 1958-1978."

${ }^{254}$ UZC, Sezione II, Trieste, Busta 92, Vol. II, Folder Associazione Universitari Irredenti, "Note from Palamara to PCM," August 25, 1955.

${ }^{255}$ Giuliano Gaeta, "Il problema di Trieste e l’Unione Europea,” Il Pensiero Mazziniano (June, 1955).

${ }^{256}$ ALN, Segreteria Politica, Folder Verbali 1955 II, "Lega Nazionale, Rome".

${ }^{257}$ ALN, Segreteria Politica, Folder 1955/1956 V, "Confidential Harabaglia to Arena di Pola," April 27, 1955.
} 
home and abroad, including Latin America. In Trieste especially the association actively mobilized the local population by means of cultural, recreational, educational, and charitable activities, such as the organization of summer camps for Triestine children. ${ }^{258}$

Moreover, the National League supported local expressions of Italian patriotism by widely celebrating Trieste's contribution to national unification, arranging memorials of the "foibe," and pilgrimages to patriotic sites, such as the military cemetery of Redipuglia which represented the sacrifice of Italian soldiers' in World War One. ${ }^{259}$ Publicly recognized as the main referent of the patriotic and émigré associations, the National League greatly benefited from the financial support of both local and central authorities in the years immediately following the London Memorandum. However, in the late 1950s and early 1960s governmental support decisively decreased. As mentioned above, this change coincided with the gradual opening of the Christian Democrats to the Left in national politics and saw a cut of about two-thirds from previous funding levels. Interestingly enough, the government's contributions to the National League quickly rose in the early 1970s, which coincided with new moments of tension with the Yugoslav neighbor. ${ }^{260}$

After 1954, the National League, led by the Christian Democrat Ugo Harabaglia and an executive council of center-right politicians, represented more than forty political groups and various patriotic associations. Although the majority of its members traditionally shared traditional democratic views, the presence of figures such as Cesare Pagnini, a former fascist and head of the local Civic Guard during Nazi-Fascist occupation, partially discredited the National League. In particular, after the Yugo-Soviet rapprochement of 1955and the 1956 elections, nationalist propaganda increasingly infected the organization. ${ }^{261}$

At this time, not only members of the National League but also the ANVGD became increasingly concerned by the communist threat. Through the pages of its press, the ANVGD

\footnotetext{
${ }^{258}$ UZC, Fondo Jugoslavia e Varie, Busta 2, Folder colonie estive organizzate dalla Lega Italiana di Trieste, Correspondence May, 1955.

${ }^{259}$ ALN, Segreteria Politica, Folder Redipuglia, "Letter to local schools," May 6, 1955.

${ }^{260}$ UZC, Sezione V, Busta 9, Vol.II, Folder Lega Nazionale Trieste, "Contributions 1963-1984."

${ }^{261}$ Il Ghibellino, "Distensione e tradimento," Il Borghese (May 27, 1955).
} 
argued that the loss of political support for the local Christian Democrats in the administrative elections of 1956 was a clear sign of the weakness of those Italian parties in Trieste that tolerated the local communist and Slovene community and their goal to transform Trieste into a "multilingual and bastard city." ${ }^{262}$ The ANVGD, while celebrating the Hungarian events as the rehabilitation of the principle of independence, also claimed that Trieste's resistance to Communism was being undermined by the Yugoslav occupation of the Istrian region. ${ }^{263}$ In requesting that the National League actively mobilize its patriotic network as a sign of protest against barbaric Soviet communism, the émigré associations aimed to direct public attention toward the communist threat that, on the Adriatic border, was forcibly removing any signs of "Italianità."264

In 1957, following the change of leadership of the local Christian Democrats, the National League continued to request economic provisions to re-launch the Triestine economy and better defend its cultural and linguistic identity from the attack of anti-national forces. ${ }^{265}$ To show its commitment to the defense of the Italian identity of Trieste and its territory, the National League celebrated irredentist heroes and patriotic anniversaries by means of postcards and pamphlets that often underlined a sense of tragedy and vehemently opposed the detractors of the Istrian cause. ${ }^{266}$ To further strengthen its public image, the National League continued its support for charitable initiatives to assist the poorest segments of the Triestine population. ${ }^{267}$

The national government, hoping to gain local support for the recently installed Italian administration, further promoted local patriotic commemorations, such as the hundredth anniversary of the birth of irredentist hero Guglielmo Oberdan. ${ }^{268}$ On this occasion the central government financed a variety of public initiatives such as the exposition of Oberdan's personal items, a

\footnotetext{
${ }^{262}$ Silvio Carli, "Trieste non si salverà senza l'unità morale degli italiani," Difesa Adriatica (June 10-16, 1956).

${ }^{263}$ Licio Burlini, "Trieste ha dato prova che si può resistere al comunismo," Difesa Adriatica (Ocotber 29-November 5, 1956).

${ }^{264}$ ALN, Segreteria Politica, Folder 1955/1956 V, "Mandel to Harabaglia," November 17, 1956.

${ }^{265}$ UZC, Sezione II, Fondo Trieste, Busta 68, Folder elezioni del Consiglio Direttivo, "Confidential CGGTT to PCM," December 31, 1957.

${ }^{266}$ Redivo, 152.

${ }^{267}$ UZC, Trieste, Sezione II, Busta 68, Folder relazione sull'Attività svolta dall'Associazione, "Lega Nazionale to PCM," July 11, 1957.

${ }^{268}$ ACS, MI, Divisione Affari Riservati 1957-1960, B.125, Folder Associazione Mazziniana Italiana, "Note from Palamara," January 4, 1958.
} 
celebrative stamp, as well as a set of round-tables to commemorate his life and patriotic spirit. Its costs were paid by a special fund of 10,000,000 lira and were listed as "expenses for the propaganda of Italianità." 269 This further confirms that even though the Italian government significantly cut financial contributions for the Italian associational network in Trieste, it still continued to support local associations whose economic, social or artistic activities underscored "moral and patriotic values that ultimately aimed to reassert the border's Italianità."270

As mentioned in the previous section, the support of Italian associations inside the ex-zone $\mathrm{B}$, by contrast, proved increasingly complicated. While ignoring the pressure of the President of the Italian Olympic National Committee (CONI) and attempting to avoid political and diplomatic tension with the Yugoslav government, the Italian government interrupted its funding of sport clubs that operated inside the ex-zone B as centers of Italian propaganda and were locally perceived as "expressions of quintessential Italianess." ${ }^{271}$ Despite this, the central government still supported Italian culture and language in the Adriatic region by means of exchange programs between Venetian and Istrian students. A similar exchange between Slovene and Triestine students, however, was opposed by both the national government and Governor Palamara who feared Yugoslav plans to use the program as a means of nationalist and ideological indoctrination among Triestine youth of Slovenian descent. ${ }^{272}$

When looking at Trieste in the late 1950s, what emerges is the image of a city in which both the initiatives of the border office and especially the patriotic rhetoric of the National League unchangeably supported its Italian identity. Thus, state institutions and local Italian associations became the object of harsh criticism by local intellectuals. In his article "La Politica delle Bandiere" (The Politics of the Flags) Carl Schiffrer argued that the defense of Trieste's "Italianità" had been

\footnotetext{
${ }^{269}$ UZC, Sezione IV, Busta 81, Folder celebrazione Oberdan, "Undersecretary of State to CGGTT,” May 13, 1958.

${ }^{270}$ UZC, Sezione II, Trieste, Busta 50, Vol.II, Folder bilancio Territorio di Trieste 1959-1960, "CGGTT to PCM: contributi speciali," March 20, 1959.

${ }^{271}$ UZC, Fondo contributi, sussidi e spese, Busta 5, Folder Trieste Circolo Canottieri Libertas di Capodistria, "Letter from President of Italian Olimpic Committee to PCM," February 5, 1958.

${ }^{272}$ UZC, Sezione II, Trieste, Busta 44, Folder scuole italiane in Jugoslavia, "Note from Undersecretary of State," June 19, 1959.
} 
used to justify public acquiescence toward ideals that were complementary to revanchist neofascism. This criticism exposed the thin line between democratic patriotism and neo-fascism and also suggested the existence of a complex system of connivance between fringes of the governing elite and right political extremism. For example, former Mayor Gianni Bartoli himself, regardless of his efforts to minimize the influence of right-wing politics on the émigré network, became the target of criticism from the new center-left leadership of the local Christian Democrats for his affinity with members of the ANVGD who clearly had a fascist past. ${ }^{273}$

At the same time, the defense of Trieste's Italian identity also allowed movements that were traditionally depicted as anti-national, such as the Communist Party, to present anti-fascism as the single expression of patriotism. As Schiffrer brilliantly summarized, Trieste's "Italianità" could easily become an object of political manipulation. ${ }^{274}$ Local resistance to legislative proposals that supported the introduction of bilinguism in judicial and administrative proceedings exposed the multi-faceted nature of this issue.

\section{Resisting the Change: Nationalist Outbursts in Trieste}

After 1958, the Italian government began to discuss a legislative proposal that, only formally approved in 2001, aimed to extend the use of Slovene language to judicial and administrative offices in Trieste. ${ }^{275}$ In response, nationalist associations were quick to remind the government that such a proposal strictly contrasted with the policies of the Yugoslav administration against Italian culture and language in the ex-zone B. ${ }^{276}$ These views, shared by the majority of the Triestine population, were expected to foment vehement protest in Trieste should such legislation be enacted. ${ }^{277}$ For example, the government's decision to grant financial contributions to the local

\footnotetext{
${ }^{273}$ AST, Fondo Bartoli, Busta 58, Corrispondenza DC, "Belci to Bartoli," February 17, 1958.

274"Due martiri dell'antifascismo triestino," L'Unità (May 14, 1957).

${ }^{275}$ MAE, Telegram 17449, "Palamara to Belgrade," December 12, 1958.

${ }^{276}$ AUS, Fondo Luigi Papo, Busta 31, "Telegram Legione del Vittoriale," February 6, 1959.

${ }^{277}$ UZC, Sezione II, Trieste, Busta 38, Folder elezioni amministrative nel Territorio di Trieste, "Confidential Note

CGGTT to PCM," April 22, 1959.
} 
Slovene community for the opening of a student center with the pro-Titoist and communist Pahor Drago as its director, had already further exacerbated ethno-political tensions inside Trieste. ${ }^{278}$ In a letter to national secretary Aldo Moro, the local Triestine Christian Democrat Corrado Belci argued that the Slovene minority already enjoyed constitutional rights and that the introduction of bilinguism was unnecessary. Belci instead suggested accommodating Slovene requests for the extension of Slovene language in public education. To minimize the loss of votes for the local DC, Belci suggested that the party deny the use of bilingual signs for public buildings, which would violate Trieste's Italian traditions and greatly benefit the neo-fascist movement. ${ }^{279}$

Local public opinion also vehemently criticized the plans of the central government to equalize the use of Italian and Slovene. Chino Alessi, director of local Il Piccolo, defined the imposition of bilinguism as the betrayal of Trieste's Italian tradition and praised the massive mobilization of the local Italian associative network. ${ }^{280}$ Similarly, neo-fascist propaganda drew parallels between the protests of the Triestine youth and the Pirano revolt of 1894, both of which they hailed as courageous. ${ }^{281}$

The National League, for its part, depicted the government's plan as a further step in making Trieste a new South Tyrol. Significant concessions to the German-speaking minority in South Tyrol had indeed resulted in the rise of local violence, a possible scenario that could further hamper social reconciliation between Italians and Slovenes on the eastern border. ${ }^{282}$ In such a tense political climate, the, Triestine demonstrations of February 1961against the government's plan to officially introduce the use of bilinguism degenerated into urban violence. The incidents, which lasted for four days, exposed popular animosity toward a decision that was locally perceived as detrimental to the Italian identity of the city.

\footnotetext{
${ }^{278}$ UZC, Sezione II, Fondo Trieste, Busta 83, Vol. II, Folder Trieste Casa dello Studente, "CGGTT to PCM," December $1,1960$.

${ }^{279}$ ASL, Fondo Democrazia Cristiana, Segreteria Politica, Moro, Corrispondenza con gli Organi Periferici, Sc.137, S.fasc. 2, "Belci to Moro," January 9, 1961.

${ }^{280}$ Chino Alessi, "No al bilinguismo," Il Piccolo (February 5, 1961).

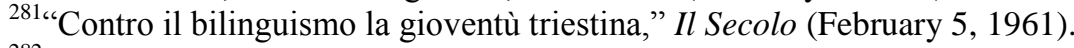

${ }^{282}$ ALN, Segreteria Politica, Folder 1961/1, "Bilinguismo," 1961.
} 
The neo-fascist press celebrated the patriotic spirit of the protesters and, evoking the deaths of November 1953, harshly criticized local authorities for their employment of unnecessary brutality. ${ }^{283}$ By contrast, the pro-governmental press highlighted the responsibility of the neoFascist Party for pre-planning the local incidents which took place in close proximity to Slovene cultural institutions. ${ }^{284}$ Communist propaganda also highlighted the responsibility of the neofascists but also concurrently stressed the government's inability to guarantee protection to the Slovene minority. ${ }^{285}$ The language and arguments of the different political parties effectively resembled those of the Fall of 1953 as all sides used the incidents to seek popular support.

The unrest in Trieste also produced friction with the Yugoslav government which saw the irredentist tones of local protests a clear sign of diehard Italian imperialist ambitions toward Istria. A set of telegrams between the Italian Embassy in Belgrade and Rome focused on the vigorous protest of the Yugoslav authorities over the offensive tone of the Triestine demonstrations against President Tito and episodes of violence that targeted Slovene organizations and citizens. In response, the Yugoslav authorities also arranged a mass demonstration in Ljubljana to condemn the Italian student protests and the Italian state's acquiescence toward forms of national and local irredentism. $^{286}$

In Trieste, communists, socialists, and Slovene representatives accused Christian Democratic Mayor Mario Franzil and the local neo-Fascist Party (M.S.I.) of inciting young demonstrators and tainting peaceful coexistence between Italians and Slovenes. Their arguments emphasized that, while the right to the use of the Slovene language was established by the Constitution and the London Memorandum, it had been portrayed by the nationalist press as unacceptable and used as a pretext for violence. For their part, neo-fascist representatives criticized the local government for its inability to properly defend the city's interests. Mayor Franzil, condemning the local incidents as an expression of a tiny and unrepresentative segment of the

\footnotetext{
283،"Duramente represse a Trieste le manifestazioni contro il bilinguismo," Il Secolo (February 7, 1961).

284“'Dimostrazioni a Trieste per l'applicazione del bilinguismo," Il Popolo (February 7, 1961).

${ }^{285}$ Antonio Perria, "Provocazione dei fascisti contro gli sloveni a Trieste," L’Unità (February 7, 1961).

${ }^{286}$ MAE, Telegram 1451, "Belgrade to Rome," February 10, 1961.
} 
Triestine population, responded to the accusations of both right and left-wing parties by

highlighting the Christian Democrats' commitment to the defense of Trieste's "Italianità" by means of the London Memorandum and its principle of reciprocity. ${ }^{287}$

Franzil's response well expressed the views and orientations of the Christian Democrats who were aware of the damage that the incidents would do to Italy's reputation internationally and feared that relations with the Adriatic neighbor would be compromised. ${ }^{288}$ To restore local order Governor Palamara imposed a ban on any public manifestation for thirty days. ${ }^{289}$ This provision was strongly criticized by the neo-fascist movement which accused the government in Rome of subservience to Tito's regime. ${ }^{290}$ Palamara, however, on behalf of Prime Minister Fanfani, assured the President of the Istrian Union that bilinguism in judicial and administrative offices would not be implemented in the city. ${ }^{291}$ While the Italian government agreed to discuss the use of bilingual signs in Trieste, it also claimed that the protection of Slovene linguistic rights was satisfactory and rather stressed the unequal treatment of the Italian minority in the ex-zone B. ${ }^{292}$

Following the Triestine events, in an article entitled "Erosione alla Frontiera" (Erosion along the Italian Frontier), the Roman-based Il Tempo, accused the government of having increasingly weakened the Italian identity of the border and strengthened Slav-communism. ${ }^{293}$ Christian Democratic figures like Bartoli also were critical of the government's support for bilinguism; however, the former Triestine mayor understood that, in order to foster public support for the Istrian cause, local neo-irredentists had to use more moderate political tones. ${ }^{294}$ In March, while celebrating the opening of the "Casa Istriana" (Istrian House) in Trieste, Bartoli praised the Istrian

\footnotetext{
${ }^{287}$ Archivio Comune di Trieste (ACT), Verbale Consiglio Comunale, Sessione Straordinaria, February 6, 1961.

${ }^{288}$ MAE, Telegram 2085, "Rome to Trieste," February 6, 1961.

${ }^{289}$ AST, Fondo CGGTT, Pacco 167, Fasc. 2/2 Divieto Pubblico Manifestazioni a Trieste, "Confidential from Palamara to PCM and MI," February 11, 1961.

${ }^{290 " I l ~ G o v e r n o ~ i t a l i a n o ~ e s e g u e ~ g l i ~ o r d i n i ~ d i ~ T i t o ~ e d ~ i m p o n e ~ p e r ~ u n ~ m e s e ~ i l ~ b a v a g l i o ~ a i ~ t r i e s t i n i, " ~ I l ~ S e c o l o ~(F e b r u a r y ~ 11, ~}$ 1961).

${ }^{291}$ AUI, 1954-1967, Busta 1, Folder 1/1, "Verbale," February 18, 1961.

${ }^{292}$ ACS, PCM, Ufficio Consigliere Diplomatico, B.27, Fasc. E47 Jugoslavia, "Confidential note of director Affari Politici Castronuovo to PCM," March 13, 1961.

${ }^{293}$ AUS, Fondo Luigi Papo, Busta 10, Fasc. Il Tempo, "Papo to Angiolillo," March 6, 1961.

${ }^{294}$ AUS, Fondo Luigi Papo, Busta 11, Fasc. Gianni Bartoli, "Bartoli to Papo," February 15, 1961.
} 
community for its patriotic irredentism, Christian values, and lack of petty nationalism. ${ }^{295}$ Bartoli argued that the Italian Istrian community did not harbor resentment or desire for revenge toward the Yugoslav neighbor. At the same time, however, the community continued to envision the territorial connection between Trieste and Istria.

Although his statement confirmed the longevity of irredentist dreams among the émigré community, Bartoli argued that the protection of the minority rights of the Italians of the ex-zone B should be the priority of the Italian government, an invaluable step to defuse feelings of local resentment. In line with these views, the Italian Ambassador to Yugoslavia, Alberto Berio, warmly encouraged the government to support Italian cultural circles in the ex-zone B in order to preserve "Italian language and traditions." "296

In the meantime, events such as the bombing of the local Slovene newspaper and the antiSlav demonstrations within the context on the hundredth anniversary of national unification further strained the relations between Italians and Slovenes inside Trieste. ${ }^{297}$ A second explosion at a Communist club in Trieste confirmed the government's fears for an uncontrolled escalation of local political violence. ${ }^{298}$ In response to these events, the local Communist Party promptly advocated the end of ethnic discrimination toward the local Slovene minority and presented itself as the epitome of Italian and Slav brotherhood across the border. ${ }^{299}$ It accused the government of connivance with the National League and criticized its inability to contain both resurgent neo-fascism and violent attacks against Slovene institutions. ${ }^{300}$ In addition, it depicted the National League as the leading expression of the local clerical and fascist forces whose goal was to use fear of Slav penetration to

\footnotetext{
${ }^{295}$ AST, Fondo Bartoli, Busta 47, Rapporti con il mondo politico, "Vigilare le Porte d'Italia," March 6, 1961.

${ }^{296}$ UZC, Sezione II, Trieste, Busta 44, Folder Estensione della legislazione jugoslava alla ex zona B ed al distretto di Capodistria, "Confidential Telegram Berio to Consolate Capodistira and MAE,"April 25, 1961.

${ }^{297}$ The bomb was found in the courtyard of the Slovene newspaper "Primorsky Dnevnik." The responsibility for such a threat, however, remained unclear. AST, Fondo CGGTT, Pacco 285, Fasc. 13/6, Ordigno esplosivo, "Mazza to PCM," April 25, 1961.

298“"Bomba all'entrata di un circolo comunista," Il Piccolo (August 12, 1961).

${ }^{299}$ The local P.C.I.. UZC, Sezione II, Trieste, Busta 83, Vol.II, Folder Partito Comunista Italiano, "CGGTT to PCM, Confidential Flyer P.C.I.," January 26, 1961.

${ }^{300}$ AFG, Fondo Apc, RP, MF0479, p.3047, "Letter from Paolo Sema,” March 17, 1961.
} 
oppose bilinguism. ${ }^{301}$ Such criticism of the government was also echoed within the pages of the Slovene newspaper Il Delo which reported that police acquiescence and widespread popular intolerance toward the Slovene minority were examples of the strength of fascism and weakness of the working class in Trieste. ${ }^{302}$

Although certain members of the National League were affiliated with the local neo-fascist movement, the appointment of President Giusto Muratti as its president in 1961 and the growing presence of representatives with centrist political orientations inside its executive council confirmed the strength of moderate views within the organization. Indeed, the dominant political orientations of the National League remained predominantly conservative rather than fascist. In his correspondence with Bishop Santin, Muratti stressed that, contrary to recent accusations, the association was not nationalist and that it opposed bilinguism on the basis of its potentially detrimental effects to the peaceful coexistence between the Italian and Slovene parts of the Triestine community. ${ }^{303}$

In particular, the National League argued that, due to the knowledge of Italian of the fifty thousand Slovenes living inside the national borders, the introduction of Slovene language in judicial proceedings appeared unnecessary and offended the last vestige of Trieste's "Italianità." The presence of translators and the teaching of Slovene language in Trieste guaranteed minority rights that in Yugoslavia had yet to be realized for the Italian minority. ${ }^{304}$ More important for the argument conveyed in this chapter, the problem of bilinguism showed that any legislative act which was locally perceived as a threat to Trieste's linguistic and cultural Italian identity could provoke a massive wave of anti-governmental sentiments with significant political costs for both local and national governing elites.

\footnotetext{
${ }^{301}$ UZC, Sezione II, Fondo Trieste, Busta 83, Vol. II, Folder Partito Comunista Italiano, "CGGTT to PCM, "ProMemoria on Local accidents," March 3, 1961.

${ }^{302}$ AFG, Fondo Apc, RP, MF0479, p.3047, “Translation Il Delo,"April 2, 1961.

${ }^{303}$ ALN, Segreteria Politica, Folder 1961/III, "Muratti to Santin," June 19, 1961.

${ }^{304}$ UZC, Sezione II, Fondo Trieste, Busta 68, Folder Nomina del Direttivo, "CGGTT to PCM, Lega Nazionale," April 13, 1961.
} 
While coping with the complex issue of bilinguism, the Italian government was also confronted by the nationalist rhetoric of political movements and associations that widely celebrated the hundredth anniversary of Italian unification. ${ }^{305}$ The central government, eager to defuse neofascist propaganda in the city, supported the Committee for the Study of "Risorgimento" that promoted a set of round-tables, talks, and books which stressed the Italian identity of Trieste. ${ }^{306}$ At the same time, properties that were used by Slovene cultural associations in the Triestine periphery were transferred to the Italian youth association. ${ }^{307}$ These decisions, as well as the placing of new restrictions on Slovene cultural manifestations along with cut to governmental contributions to the Slovene Cultural and Economic League, met the approval of the Italian community and especially its local émigrés; however, they were used by both local Slovene and communist organizations to accuse the Italian authorities of political and social discrimination, an issue that aroused diplomatic tension between Italy and Yugoslavia. ${ }^{308}$ In an attempt to reduce political tension with the Yugoslav neighbor, Palamara decided to exclude the National League from the Committee for the Anniversary of Italian Unification. ${ }^{309}$ A few months after, the local Governor also notified the association that, due to financial difficulties, the central government was forced to reduce its financial support for local patriotic initiatives, such as the pilgrimage to "Redipuglia." ${ }^{310}$

In commenting on these decisions, Bartoli argued that the government was disregarding the patriotic role of the National League. Moreover, during the official celebration of Italy's hundredth anniversary of national unification, the central government downplayed symbols of Italian patriotism such as Fiume and Dalmatia, and therefore, minimized the contribution of these cities to national "Risorgimento." 311 The former mayor of Trieste edited a pamphlet which recalled the

\footnotetext{
305 “Solenne celebrazione in Italia del centenario dell'unità nazionale” Il Secolo (June 28, 1961).

${ }^{306}$ UZC, Sezione II, Fondo Trieste, Busta 93, Folder Comitato di Trieste per la Storia del Risorgimento, June 9, 1960.

${ }^{307}$ UZC, Sezione II, Fondo Trieste, Busta 93, Folder Circoli Sloveni di Cultura Popolare, January 21, 1960.

${ }^{308}$ Since its creation in 1955 , local authorities reported to the central government the clear political goals pursued by this association and strongly discouraged any financial contributions due to its anti-Italian orientation. UZC, Sezione IV, Busta 11, Folder Lega Economica Culturale Slovena, "Reports from Palamara,"1959-1962.

${ }^{309}$ ALN, Segreteria Politica, Folder 1961/III, "Letter to Palamara," January 31, 1961.

${ }^{310}$ ALN, Segreteria Politica, Folder 1961/V, "Confidential Letter Palamara to Muratti," May 16, 1961.

${ }^{311}$ ASL, Fondo Mario Scelba, Versamento II, Corrispondenza, B.17, f.199, "Note on Triestine situation,” February 4, 1961.
} 
heroism of about seventy gold-medal holders from the region, dismissed the equation of nationalism with patriotism, and broadly celebrated Trieste's role as center of Adriatic irredentism. ${ }^{312}$ Bartoli ultimately urged the national community to neither forget nor renounce its legitimate interests, in particular Italian formal sovereignty over the Istrian region. ${ }^{313}$

During the centennial celebrations in Trieste, nationalist propaganda emphasized that concessions to the Slovene minority disregarded the continuous violence and discrimination toward the Italian community of the ex-zone B. ${ }^{314}$ Its anti-Yugoslav and especially anti-Tito slogans caught the attention of both local Slovene associations and Yugoslav observers who vehemently protested to the Italian government. ${ }^{315}$ At the same time, local communist leader and parliamentary representative Vittorio Vidali protested to the central government over the alleged fascist and irredentist tones of the centennial celebrations in Trieste. During a Parliamentary session Vidali complained that, during the local official celebration, Triestines were chanting "Dux, Dux!" The government, however, responded to Vidali that the protesters were yelling "Fiume, Fiume!" The government argued that, as these words simply reflected the endurance of local feelings of brotherhood toward the émigrés, it had approved the police's decision not to intervene and therefore prevent possible skirmishes with the local population. ${ }^{316}$ Following this parliamentary debate and, perhaps in response to local criticisms, President of Council Fanfani delivered a significant speech in Trieste in June 1961 in which he emphasized the entire nation's eternal debt to the city and the commitment of the Italian state to its socio-economic progress. ${ }^{317}$

In particular, state financial support to a variety of local patriotic associations demonstrated that local and central authorities were politically invested in the preservation of Trieste's Italian identity; at the same time, however, they feared the detrimental effect of irredentist demonstrations

\footnotetext{
${ }^{312}$ ASL, Fondo Mario Scelba, Versamento II, Corrispondenza, B.17, f.199, Pamphlet on contributions of Julians and Dalmatians to Risorgimento.

313،"Trieste rievoca commossa l'epopea del Risorgimento," Il Piccolo (March 26, 1961).

${ }^{314}$ ACS, MI, Gabinetto, Fasc. Correnti, 1961-1963, B.10, Fasc. 11095/87 Trieste, Centenario Unità d'Italia, "Palamara to PCM," March 27, 1961.

${ }^{315}$ UZC, Sezione IV, Busta 50, Folder situazione politica generale del Territorio di Trieste, "Confidential MAE to PCM," May 22, 1961.

${ }^{316}$ AST, Fondo CGGTT, Pacco 167, Fasc. 2/2 Interrogazione Vidali, "PCM to Vidali," May 12, 1961.

${ }^{317}$ ASR, Sezione I, Attivitá Politica, Serie 1, ss.4, Busta 12, fasc.11.44, “Fanfani’s speech,” June 21, 1961.
} 
on Italian-Yugoslav diplomatic relations. For this reason, Governor Palamara refused to authorize the national convention of the Istrian Union in Trieste. ${ }^{318}$ The newly-established Committee of National Defense, which consisted of Catholics and patriots interpreted this decision as a clear sign of the widespread defeatism of the Italian government and mobilized to publicly reiterate the image of the ex-zone B as the territorial extension of "the geographical and ethnic national borders." ${ }^{319}$

Although these views further confirmed the endurance of past irredentist views among the most nationalist segments of the émigré community, most of the Triestine population had over time resigned themselves to the territorial loss of the ex-zone B and focused instead on the preservation of the Italian cultural identity of the city. Meanwhile, nationalist associations which had traditionally sought to re-incorporate the former Istrian territory inside national borders gradually endowed their propaganda with a more populist tone and highlighted the themes of a degenerated and corrupted democracy that was unable to respond to the real needs of the city. ${ }^{320}$

After the tension produced by the issue of bilinguism and the centennial celebrations in Trieste, the summer meeting between the Italian and Yugoslav presidents eased diplomatic relations, yet the result of the local census in Trieste newly upset the Adriatic friendship. ${ }^{321}$ Yugoslav authorities, receiving the complaints of the local Slovene associations, requested that the Italian government change the official survey as it misrepresented the real size of the Slovene community and, therefore, violated the spirit of the London Memorandum. ${ }^{322}$ Rome, however, rejected Yugoslav accusations and in turn criticized Belgrade for the anti-Italian tone of the local demonstrations in Capodistria. ${ }^{323}$

\footnotetext{
${ }^{318}$ ACS, MI, Dipartimento della Pubblica Sicurezza, Cat.G, Associazioni, 1944-1986, B.363, Folder Unione degli Istriani, "Palamara to PCM," July 11, 1961.

${ }^{319}$ ACS, MI, Dipartimento della Pubblica Sicurezza, Cat. G, Associazioni 1944-1986, Folder Movimento Nazionale per 1'Italianità dell'Istria, "Note from Palamara," August 23, 1961.

${ }^{320}$ UZC, Sezione IV, Busta 50, Folder situazione politica generale del Territorio di Trieste, "Confidential CGGTT to PCM, Movimento Combattentistico Italiano," November 27, 1961.

321 “Italia e Jugoslavia," Il Popolo (July 1, 1961).

${ }^{322}$ UZC, Sezione VI, Busta Censimento, "Letter from Slovene associations to National Governmental Institutions," October 4, 1961.

${ }^{323}$ Maria R. Boensch “Il genocidio italiano a Trieste,” Il Borghese (October 5, 1961).
} 
In particular the Italian government, eager to respond to the local population's wishes to reassert Trieste's Italian identity, welcomed Palamara's proposal to raise the Italian flag in Trieste's main square. ${ }^{324}$ Such symbolic acts were widely advertised in the local press and attended by patriotic youth associations. ${ }^{325}$ These ceremonies, while opposing anti-Italian propaganda across the border, also reinforced ethnic and ideological stereotypes that continued to perceive Yugoslav communism and the Slovene community as the main threat to Trieste's "Italianità." This partially explains the reason why Vidali's visit to Slovenia aroused local criticism among the anti-communist segments of the Triestine population. ${ }^{326}$ The rapprochement between the local and Yugoslav communist parties, however, was intended to show communist support for regional autonomy, improve opportunities for political proselytism, and establish a political foothold in the émigré community. ${ }^{327}$

Nevertheless, Vidali's visit also provoked the criticism of the President of the national partisan association who depicted Tito's regime as fascist rather than socialist. ${ }^{328}$ Similarly, centerleft wing movements criticized Vidali for his inconsistency toward Tito's regime, which was now suddenly depicted as the house of true socialism. ${ }^{329}$ As a consequence, the Italian and Slovene branches of the local communist party again clashed and some supporters of the movement shifted their political loyalty toward the local socialists. ${ }^{330}$

Following 1954, the growth of the Triestine socialist movement provided local and national Christian Democratic leaderships a unique opportunity to reshape their political strategy toward the border and promote a new image of the eastern frontier as a space of mutual political understanding and economic cooperation rather than a center of ethno-nationalist rivalries. While firmly opposing local Communism, the local Christian Democrats had gradually distanced themselves from their

\footnotetext{
${ }^{324}$ UZC, Sezione IV, Busta 50, Folder cerimonia alzabandiera a Trieste, "Palamara to PCM," December 8, 1961.

${ }^{325}$ UZC, Sezione VI, Dall’Ufficio per le Zone di Confine all'Ufficio Regioni, "Capitoli di spesa, 1961-1962."

${ }^{326}$ UZC, Sezione II, Fondo Trieste, Busta 83, Vol.II, Folder Partito Comunista Italiano, "Secret Telegram Italian Embassy in Belgrade," February 27, 1962.

${ }^{327}$ AFG, Fondo Apc, RP, MF0498, p.1820, “Comitato Regionale PCI,” 1962.

${ }^{328}$ UZC, Sezione IV, Busta 50, Folder situazione politica generale del Territorio di Trieste, "A.N.P.I. riunione della direzione provinciale," March 12, 1962.

${ }^{329}$ UZC, Sezione II, Fondo Trieste, Busta 83, Vol. II, Flier Socialist Democrat Federation, February, 1962.

${ }^{330}$ AFG, Fondo Apc, RP, MF0498, p.0498, "Laurenti to Togliatti," October 12, 1962.
} 
pre-1954 nationalist rhetoric and could now vigorously embrace the experiment of the center-left. ${ }^{331}$ Aware of the endurance of irredentist sentiments among the émigrés and fringes of the Triestine population, the Triestine DC also attempted to attack socio-political intolerance. For example, it created local youth circles that gathered all the representatives of Triestine associations regardless of political orientations and ethnicity. ${ }^{332}$

Initiatives like these were only partially successful in countering local extremist propaganda. On the anniversary of the 1948 Tripartite Declaration, groups of students mourned the memory of the November deaths and shouted anti-Tito slogans. Even though some of them were prosecuted as apologists of fascism and arrested for offensive statements against the head of a foreign state, the charges were dropped. ${ }^{333}$ Right-wing extremists especially targeted Slovene personalities and carried out a bombing of Trieste's communist headquarter in the San Giacomo neighborhood. ${ }^{334}$ In addition, they set off two explosions at the Yugoslav embassy and the Yugoslav Consulate in Rome, respectively in 1962 and $1964 .{ }^{335}$

In April 1962, after the bombing of the residence of local anti-fascist Carl Schiffrer, the local state authorities were publicly accused by the political opposition for funding terrorist groups under the cloak of cultural associations. Newly appointed local Governor Libero Mazza responded to these accusations by claiming that even though funds were provided to associations with cultural, philanthropic, and recreational goals, "no money was provided to political groups or associations with political goals." ${ }^{336}$ In addition, the culprit for the attack on Carl Schiffrer's house was arrested as well as 92 others who had been convicted for acts of political violence during the early 1960s. In reporting these arrests to the central authorities, Mazza went so far as to deny the existence of a

\footnotetext{
${ }^{331}$ This decision mirrored the leading orientation of the national party which, fearing the rise of communism, proved willing to strengthen political ties with the socialist party. ALS, Fondo Mario Scelba, Versamento I, Attivitá di Partito, B.21, fasc.165, February 22, 1962.

${ }^{332}$ Local Dioceses Trieste (DT), Fondo Coloni, B.2, Folder attività giovanile, 1962.

${ }^{333}$ UZC, Sezione IV, Busta 50, Folder situazione politica generale del Territorio di Trieste, "CGGTT to PCM," May 19, 1962.

${ }^{334}$ AST, Fondo CGGTT, Pacco 227, fasc. 4/2, Esplosione bomba a San Giacomo, August 12, 1962.

${ }^{335}$ FBIS (July 2, 1962 and December 16, 1964).

${ }^{336}$ AST, Fondo CGGTT, Pacco 239, Fasc. esplosione bomba Prof. Schiffrer Carlo, "Telegram from Mazza to MI," April 3, 1962.
} 
right extremist and terrorist network in Trieste. ${ }^{337}$ As discussed above, however, nationalist associations as well as local feelings of enmity and suspicion toward the Slovene community did not disappear from Trieste.

Political distrust toward Slovene political groups remained significant also among the Triestine governing elites. In anticipating the municipal elections of November 1962, for example, the local electoral committee prohibited representatives of the Slovene minority from using a single party name in Slovene. ${ }^{338}$ In so doing, the local governing elites hoped to both weaken the Slovene movement and dismiss any accusation of acquiescence towards the local Slovenes. Despite this, the elections resulted in the weakening of support for Christian Democrats, communists, and neofascists, as well as the increase in popular support for the socialist and liberal parties.

The electoral results pointed to the strengthening of both progressive and moderately conservative political views among Triestine Italians who, while moving away from extremist movements, also looked for alternatives to the Christian Democrats. The elections also revealed that the Triestine society and especially its youth had experienced a gradual process of democratization which weakened the neo-fascist movement and its propaganda against the Slovene segments of the Triestine population and their cultural institutions. ${ }^{339}$ At the same time, the presence of two independence movements not only proved the unexpected endurance of popular political ambitions for home rule, but also emphasized the failure of the new administration to win the support of a segment of the local community that continued to harbor dreams of a separate political status for Trieste and its territory. ${ }^{340}$

\footnotetext{
${ }^{337}$ The attack on Carl Schiffrer's house was followed by months of tension and debates. AST, Fondo CGGTT, Pacco 224, fasc. 2/2, Atti dinamitardi a Trieste, May 22, 1962.

${ }^{338}$ UZC, Sezione IV, Busta 7, Vol.I, Folder elezioni politiche a Trieste, "Slovene Representatives to PCM and President of Republic," October 14, 1962.

${ }^{339}$ IRSML FVG, Fondo Burno Pincherle, Busta 15, fasc. Mozioni MSI, "Intervention of Bruno Pincherle," February 4, 1963.

${ }^{340}$ UZC, Sezione IV, Busta 7, Vol.I, Folder elezioni politiche a Trieste, "MAE to PCM," November 23, 1962.
} 


\section{The Return of the Italian State: Success or Failure?}

In Trieste, the government's inability to restore its port economy weakened its relationship with the city as local sentiments of "Italianità" increasingly related to the political and economic performance of the new Italian administration rather than its pre-1954 efforts to maintain Italian sovereignty of the city and its territory. Between 1954 and 1962, Yugoslav violations of the London Memorandum as well as the city's seemingly unstoppable slide toward impoverishment adversely affected the image of the new Italian administration. In such a context, the new course of the state's policy for the border and the progressive views of its Christian Democratic leadership increasingly detached from its former nationalist rhetoric and met widespread concern among key elements of the local population.

Local political changes and economic insecurity, the detention of Italian citizens in Yugoslavia, the forced emigration of Italians from the ex-zone B, and the prolonged presence of the émigrés in local camps vividly highlighted the negative aftermath of the London agreements. The widespread discontent among the incoming Istrians and the local Triestines was promptly exploited both by the political opposition and the Italian associational network to criticize the Italian state's diplomatic weakness and inability to protect the Italian minority in the ex-zone B. It was also used by local political extremists to foment ethnic and ideological antagonism toward local communists and Slovenes. The central government, caught between the criticism of both patriotic and émigré associations as well as the need to further advance the new Adriatic friendship, sought to avoid a final resolution of territorial issues while improving economic relations with Tito's regime.

Notwithstanding a new conciliatory foreign policy of co-existence with Tito's Yugoslavia, the Italian government enhanced patriotic celebrations and rhetorically reasserted formal territorial claims over the ex-zone B, finding invaluable support in the Catholic Church. More importantly, Rome continued to promote Trieste's Italian cultural and linguistic identity by means of the Office of Border Zones (UZC) as well as support for politically moderate patriotic and émigré associations. Among them, the National League and figures like former Mayor Bartoli played a 
pivotal role in promoting the Italian identity of the Triestine territory by projecting an ideal territorial and especially cultural continuity between Trieste and its Istrian region.

The intransigent views of the local neo-irredentist network, its irrepressible defense of Italian sovereignty of the ex-zone $\mathrm{B}$, and its opposition to any provision that excluded the principle of reciprocity outlined in the London Memorandum, inflamed local tensions and strained relations between Rome and Trieste. Still experiencing the process of democratization and excluded from the Italian economic miracle, people in Trieste perceived Yugoslav discrimination toward the Italians of the ex-zone B and the Italian concessions to Trieste's Slovene minority as frightening threats to the city's "Italianità." These fears and anxieties, best exemplified by the harshness of the political debate that surrounded the issue of bilinguism and the centennial celebration of national unification, ultimately produced episodes of ethno-political violence in Trieste. These events, while confirming the endurance of former nationalist views inside the Triestine community, also revealed widespread popular opposition to the opening of the Christian Democrats to the Socialist Party in both national and local politics. ${ }^{341}$

\footnotetext{
${ }^{341}$ Vezzà and Comelli, 97-101.
} 


\section{Chapter 4}

\section{Trieste's Red Years: the Last Breath of Adriatic Irredentism}

Throughout the 1950s and early 1960s the government's failed attempts to restore Trieste's port economy and protect the Italian minority in the ex-zone B decisively weakened the effects of its patriotic rhetoric in the Julian city. At the same time, it also enhanced a sense of local disillusionment toward the new Italian administration and facilitated the sporadic resurgence of ethno-political violence against the Slovene minority. Thus, the empty rhetoric of "Italianità" and the economic decline of the city aroused local animosity toward the Christian Democrats. In 1963, the shift of the Christian Democratic Party to the left in national politics and the establishment of the Friuli Venezia Giulia autonomous region were therefore received with increasing apprehension in Trieste, especially among émigré and patriotic associations.

This chapter investigates the effects of the government's new center-left political configuration, its economic plan for the local port, and its foreign policy of "active co-existence" with Tito's regime on Italy's former politics of identity toward the border as well as Trieste's response to it between 1963 and 1968. It argues that the progressive views of the Christian Democrats both in domestic and foreign policy ultimately swept away any residual irredentist ambition of the governing elites toward the ex-zone B. In Trieste, however, fringes of the local Christian Democrats as well as segments of the Triestine community, perceived the new political and economic strategy of the Christian Democratic Party as an impending threat to the Italian identity of the city and, reading the socio-political reality of the border through the lenses of the Cold War, firmly opposed it.

In the mid-1960s, both the Hrescak case and the decisions of the "Comitato Interministeriale Programmazione Economica" (Interministerial Committee for Economic Planning, hereafter, CIPE) magnified the complexity of local readings of Trieste's "Italianità." Both issues sparked forms of popular opposition which exposed the growing tension between the central government in Rome and key segments of the Italian population in Trieste. While the local political debate as well as the 
Hrescak protests demonstrated the survival of nationalist views, the CIPE plan was met with the widespread opposition of not only the port workers but indeed the entire city toward the central government. Above all, the controversy surrounding CIPE exposed the strength of ambitions for political autonomy inside Trieste. The central government, however, partially ignored the longstanding political implications of local dissent over economic issues as it firmly pursued a definitive settlement of the border dispute.

\section{A Costly Turn: the Experiment of the Center-Left in Trieste}

As discussed in the previous chapter, the 1960 fall of Christian Democratic Fernando Tambroni's center-right government marked the end of political centrism, a former political configuration that, beginning in the immediate post-war years, had relied on the alliance between the Christian Democrats and lay parties of moderate views. From the early 1960s, therefore, the Christian Democrats aimed to include leftist forces within the government, a complex political process that was delayed by the internal division of the Christian Democratic Party. ${ }^{1}$ In 1963 this process culminated in the creation of a center-left coalition government which politically relied upon the support of Christian Democrats, Republicans, Social Democrats, and Socialists. ${ }^{2}$ The gradual opening to the left was also transposed to foreign policy and shaped the new strategy of the Christian Democratic leader and Foreign Minister Aldo Moro, an Italian form of what the West Germans later called "Ostpolitik.",

As a consequence, the Italian government, while firmly supporting political relaxation between the Western and Eastern blocs, showed a more friendly and conciliatory attitude towards Tito’s regime. ${ }^{4}$ In 1963, during Prime Minister Fanfani’s visit to Yugoslavia, the Italian political adviser Gianfranco Pompei met with Yugoslav Ambassador Vejvoda and agreed to advance the

\footnotetext{
${ }^{1}$ See Nicola Tranfaglia, "Dalla crisi del centrismo al compromesso storico," in Storia dell'Italia repubblicana (Vol. II), ed.Francesco Barbagallo (Torino: Giulio Einaudi Editore, 1995), 7-111.

${ }^{2}$ See Francesco Perfetti, L'Italia, Moro e il centro-sinistra: luci e ombre, ed. Perfetti, 9-27.

${ }^{3}$ Garzia (2011), 12.

${ }^{4}$ Sergio Serge, "Per essere presi sul serio," Rinascita (March 30, 1963).
} 
border negotiations in an informal and discreet discussion. While supporting talks over the northeastern border between Italy and Yugoslavia, the Italian diplomat clearly understood that the Yugoslav neighbor intended to "transform the demarcation line between the zone A and B into the state border." 5

Although the formal recognition of Yugoslav sovereignty over the northern part of the Istrian region could have effectively enhanced the international prestige of the Italian government and greatly benefited bilateral relations, Rome also understood the political implications that any definitive renunciation of the ex-zone B could have on its popularity. Especially in Trieste such a decision could provoke a significant loss in popular support for the Christian Democrats who were already being criticized for their opening to the non-communist parties of the left. This process, which had begun with the generational change of the Christian Democratic leadership in the mid1950s, culminated with the election of progressive and local Christian Democratic leaders such as Corrado Belci, supporter of Aldo Moro, and Giacomo Bologna, supporter of Amintore Fanfani, to the national Parliament in 1963.

Between October 16 and 19, 1963, following the announcement of the formation and implementation of the new center-left coalition in Trieste, hundreds of right-wing students and members of the neo-fascist movement arranged a set of demonstrations in front of both the local headquarters of the Christian Democrats and the city council. ${ }^{6}$ Due to their threatening tone, the local police disbanded the protesters and arrested some of the main agitators. ${ }^{7}$ In response to the arrests, patriotic and émigré associations joined the protest of the "Giunta Giovanile di Vigilanza Nazionale" (National Defense Youth League).

This group, the leading voice of the local right-wing student movement, published and distributed a pamphlet that claimed that "Christian Democrats and Social Democrats forgot the interests of the nation in order to gain a few thousand votes of the local Slovenes." The pamphlet

\footnotetext{
${ }^{5}$ ACS, PCM, Ufficio Consigliere Diplomatico, Busta 27, Fasc. E47, “Conversazione con Ambasciatore Vejvoda in occasione del viaggio di Fanfani in Jugoslavia,” January 31, 1963.

${ }^{6}$ Vezzà and Comelli, 104.

${ }^{7}$ UZC, Sezione IV, Busta 7, Vol. I, Folder elezioni provinciali e amminstrative,"Mazza to PCM,"October 16, 1963.
} 
declared that, in forgiving the drama of the "foibe" and the forced emigration of 300,000 Italians from Yugoslavia, this policy had one single name: "betrayal!"» The harsh tone and bitter accusation of the local protesters clearly revealed the widespread hostility of the right-wing part of the Triestine population which portrayed the political shift to the center-left as a deadly threat to the city's Italian identity. ${ }^{9}$ Above all, the neo-fascist movement, under the guise of national patriotism, used its propaganda to target the Triestine youth which, differently from the other Italian cities and until the late 1960 s, promptly responded to the nationalist rhetoric with mass mobilization. ${ }^{10}$

The national elections of 1963, however, witnessed the success of the Christian Democratic coalition of the center-left inside Trieste as well as the slight loss of popular support for the neoFascist Party (Italian Social Movement, M.S.I.). ${ }^{11}$ Due to a new electoral law, however, only one of the Socialist Democratic candidates was elected to the Senate. In addition, the Triestine Communist Party was successful in electing Vittorio Vidali to the Senate and the Slovene candidate Maria Bernetic to the Chamber of Deputies, further consolidating its role as the leading promoter of Italian-Slav brotherhood in Trieste. $^{12}$

Although the Christian Democrats remained the most popular party at national and local level, the choice of its Triestine candidate for the Senate was accompanied by a heated debate which revealed internal hostility toward the new political strategy of the center-left. Bartoli argued that, by selecting the ex-Consul in Capodistria as the party's candidate for the Senate, the Roman elites had behaved like fascists. This decision, also motivated by the leftist views of the ex-Consul, completely disregarded the strong conservative views of the Triestine community. While indignantly addressing Moro and Fanfani as "criminals," the most conservative fringes of the local Christian Democrats firmly supported Bartoli’s grievances against the party’s policies. ${ }^{13}$ As

\footnotetext{
${ }^{8}$ UZC, Sezione IV, Busta 7, Vol.I, Folder elezioni provinciali e amminstrative,"Flyer Giunta Giovanile di Vigilanza Nazionale," October 19, 1963.

9"Il nostro patriottismo la nostra fede nazionale," Trieste (September-October, 1963).

${ }^{10}$ Vezzà and Comelli, Trieste a destra, 116.

${ }^{11}$ UZC, Sezione IV, Busta 11, Folder elezioni politiche, 1963.

${ }^{12}$ AFG, Fondo Apc, RP, MF0490, p.3198, "Senate Candidate for Trieste,” February 16, 1963.

${ }^{13}$ AST, Fondo Bartoli, Busta 57, Carteggio, "Letter from DC Members of Committee of Foreign Affairs Bettioli to Bartoli," January 12, 1963.
} 
demonstrated by this case, the party's turn to the left was neither a smooth nor a linear process and was also accompanied by an internal diatribe between the progressive and conservative fringes of the Christian Democrats.

Meanwhile, the political debate that accompanied the creation of the Friuli Venetian Julian autonomous region further inflamed the anti-governmental propaganda of the political opposition. Supporters of the new autonomous region claimed that this new political entity would complete Trieste's reintegration within the national community. ${ }^{14}$ In a similar fashion, left-wing parties depicted the autonomous region as the ideal means to overcome past local rivalries and restore Trieste's economy. ${ }^{15}$ Right-wing parties, patriotic as well as émigré associations, in stark contrast, portrayed the autonomous region both as a threat to the Italian identity of Trieste and national political unity.

In a speech in Trieste, the monarchist representative Alfredo Covelli described the autonomous region as the outcome of the post-war clerical-communist Republic. Its creation, he argued, exposed Trieste to the threat of pan-Slavism through the "Trojan horse of political and modern Titoist communism."16 This nationalist rhetoric aimed to brand the victory of the center-left coalition as the preamble to the definitive renunciation of what Covelli called the "holy rights" over the ex-zone B. Such arguments were not uncommon among post-war nationalists whose rhetoric connected the rise of the political left to the demise of national security, especially in Trieste.

These views belonged to a political minority that read the border's condition through the lenses of past Adriatic irredentism and were alarmed by the increasing statewide apathy over the issue of the ex-zone B. Although gradually minimized within national public opinion, this issue remained important within local public discourse. Any sign of acquiescence toward Yugoslav territorial claims, indeed, was often negatively judged and widely publicized inside the pages of the local press. In August 1963, for example, Yugoslav Consul Rudi Janhuba wrote a letter to Chino

\footnotetext{
14،"Moro rileva l'importanza di Trieste nella nuova regione," Il Piccolo (May 8, 1964).

${ }^{15}$ Sapelli, 226.

${ }^{16}$ Archivio Storico Camera dei Deputati (AC), Fondo Covelli, Discorsi e Scritti, Busta 2, Fasc.117, 1963.
} 
Alessi, director of Trieste's newspaper Il Piccolo in which he harshly criticized its publication of offensive images against President Tito during his Brioni's meeting with Italian Senate's President Cesare Merzagora. Freedom of the press, Janhuba argued, "should not equate to freedom of insulting other heads of state." ${ }^{\prime 17}$

This episode provoked Yugoslav diplomatic protests and created political tension between Italy and Yugoslavia. Merzagora, acknowledging Yugoslav protests, recognized that the issue of the ex-zone B was still incredibly sensitive and was intimately related to the memories of both world wars. The political costs of its renunciation, therefore, were too high, regardless of Tito's desire to "clear up the issue." ${ }^{18}$ In his letter to local Christian Democratic secretary Guido Botteri, Bartoli also reported local widespread hostility against the accommodating views of the central government toward the local Slovene minority and Yugoslav socialism. These views well mirrored the general feelings of the nationalist and conservative elements of the Triestine community which continued to perceive the opening to the left and defeatist attitudes toward the ex-zone B as a prelude to the advancement of the goals of Yugoslav communism within Trieste. ${ }^{19}$

In confronting the political experiment of the center-left, "Costituente Adriatica" (Adriatic Constituent), the most nationalist fringe of the émigré associational network, attempted to attract national and international attention for the issue of the ex-zone B. After his famous speech in Berlin, the executive committee of the association sent President John F. Kennedy a telegram during his trip to Italy. In the letter, the committee rhetorically depicted the past struggle of Venetian and Roman civilization against the barbarian Slavs, pleading for "the extension of American firmness on Berlin to Istria and Dalmatia.,"20

In addition to reaching out the American President, on November 3, 1963, members of "Costituente Adriatica" (Adriatic Constituency) recreated the "Associazione Nazionale Italia

\footnotetext{
${ }^{17}$ AST, Fondo CGGTT, Pacco 278, fasc. 6/11, Esposto Console Jugoslavia, "Letter from Yugoslav Consul to Director Chino Alessi," August 29, 1963.

${ }^{18}$ ACS, PCM, Ufficio Consigliere Diplomatico, Busta 27, Fasc. E47, “Incontro Merzagora-Tito," September 4, 1963.

${ }^{19}$ AST, Fondo Bartoli, Busta 87, DC/Segreteria Politica, "Bartoli to Botteri," December 12, 1963.

${ }^{20}$ AUS, Fondo Luigi Papo, Busta 37, Fasc. Messaggi, "Telegram to Kennedy," July, 1963.
} 
Irredenta" (National Italian Irredentist Association, ANII). ${ }^{21}$ This association, which later merged into the "Centro Studi Adriatici" (Center for Adriatic Studies) in 1964, presented itself as the heir of the 1877 “Associazione in Pro dell'Italia Irredenta" and aimed to unify the panoply of post-war nationalist associations that had emerged after 1945. In its statute, the association claimed to be apolitical and that its goal was to defend the moral and spiritual values of Italian and European civilization as well as the "Italianità" of the "unredeemed" lands. By means of local and national councils, it intended to create an informational network whose ultimate goal was the revision of the territorial borders that had been "arbitrarily changed by the Peace Treaty of 1947." 22 In its propaganda the association repeatedly referred to a set of Risorgimental and Mazzinian values such as the idea of homeland and self-determination, ideals that still held significant meaning among large strata of national public opinion and best served its irredentist goals.

The constitutive assembly of the National Italian Irredentist Association extended its invitation to important figures of moderate or extremist irredentist sentiments, in particular Bartoli and the ex-commander of the X-Mas Valerio Borghese. The former mayor of Trieste responded by espousing a single and cohesive irredentist action for the association to uphold the provisional rather than definitive status of Yugoslav administration of the ex-zone B. Detaching himself from extremist nationalist views, however, Bartoli claimed that the association should maintain its political autonomy yet adhere to the Constitutional political order and conform to the democratic spirit of the Julian and Dalmatian population. By contrast, Valerio Borghese called for the opening of the association to figures of the past fascist regime who had been affiliated with the national M.S.I. and carried out a public campaign for the re-appropriation of former Italian territories in the Adriatic region, and an unrepentant refusal to compromise with the national government. ${ }^{23}$ Even though both personalities opposed the experiment of the center-left and feared the penetration of Slav-Communism, Bartoli espoused the use of political dialogue and diplomatic negotiations to

\footnotetext{
${ }^{21}$ AUS, Fondo Luigi Papo, Busta 3, fasc.13, "ANII," October, 1964.

${ }^{22}$ AST, Fondo Gianni Bartoli, Busta 30, fasc. 204.

${ }^{23}$ AUS, Fondo Luigi Papo, Busta 37, Fasc.Constituente Adriatica inviti e adesioni, "Correspondence," 1963.
} 
safeguard Italian territorial rights of the ex-zone B, minority rights in Istria, and the Italian culture in the Adriatic region. Contrary to Borghese's mindset, Bartoli refused to cooperate with figures of doubtful patriotic sentiments whose reputation, political adventurism, and extremist views discredited the émigré community.

Bartoli's moderate views were generally shared by the "Lega Nazionale" (National League) which represented the leading expression of the local neo-irredentist movement in Trieste. As examined in the previous chapter, this association uninterruptedly propagated the Italian identity of the city and its territory. After the DC's opening to the left, its relations with both the local and national Christian Democratic leadership drastically changed. From the late 1950s, the conservative faction of the Triestine Christian Democrats had been gradually marginalized inside the party and its leadership was entrusted to more progressive Triestine figures who identified with the leadership of Aldo Moro, also known as "Morotei." This faction represented the majority of the party in Trieste and, until 1965, its progressive policy was also supported by the minority of the party which identified with Fanfani, the "Fanfaniani." ${ }^{, 4}$ Although both leaders initially promoted the center-left, Fanfani and his supporters would move to more conservative positions in the late 1960s and early 1970s, ultimately opposing the Osimo Treaty and breaking the party's unity in Trieste.

In 1963, the new local Christian Democratic governing elite was expected to better respond to Trieste's changing historical and political context and also facilitate its administrative reintegration inside the Italian state. The creation of the new autonomous region, especially, represented the hallmark of the new political strategy of the Italian government toward the eastern border. Local Christian Democrat secretary Botteri claimed that, differently from the years before 1954, the defense of Trieste's "Italianità" was not limited to the Triestine community; rather, it needed to address the priorities and necessities of the entire nation and any sign of self-defense coming from the local community would be interpreted a priori as distrust toward the new Italian state.

\footnotetext{
${ }^{24}$ For an interesting study of the changing Triestine political context and the local Christian Democratic Party see Andrea Dessardo, Vita Nuova 1945-1965. Trieste nelle pagine del settimanale diocesano (Trieste: IRSML, 2010).
} 
Above all, Botteri argued, the time to fight with Yugoslavia over was over and the most important thing was the new peaceful spirit of dialogue and cooperation between the city and its Adriatic neighbor. Trieste, he concluded, would "finally return to its traditional role of an open frontier city." 25 These views were greatly shared by the majority of the Italian Christian Democrats and their allies and demonstrated the increasing strength of support within governing circles for a moderate and progressive strategy toward the border. Well summarized in the expression of "Adriatic détente," it provided an outstanding opportunity to put an end to the needless conflict over ex-zone B, minimize socio-political tensions inside Trieste, and strengthen both economic and political relations with Tito's regime.

At the same time, however, national Christian Democratic figures such as former President of Council Mario Scelba were critical of the party's opening to the Social Democrats and Socialists. In response to a letter from Bartoli in which the former Trieste's mayor condemned Italy's new friendly attitude toward Yugoslav socialism as foolishness, Scelba acknowledged his regrets for having failed to stop the party's turn toward the left. While referring to the Triestine context, Scelba agreed with Bartoli that the nationalist rhetoric of Tito's regime clashed with Italy's territorial rights over the ex-zone B and fanned the local flames of Italian nationalism. ${ }^{26}$

Indeed, the turn toward the left could have resulted in a possible "hemorrhage of votes toward the right," especially among voters who were strongly affiliated with patriotic associations of clear anti-communist inspiration. ${ }^{27}$ In an attempt to minimize this risk, Christian Democrat politicians such as Aldo Moro asked Minister of Interior Paolo Taviani to maintain financial support to the patriotic network and especially its main association, "Alleanza Tricolore Italiana" (Italian Tricolor Alliance) ${ }^{28}$ This decision was motivated by the pivotal role that the association had traditionally played in swinging the vote of its members toward the Christian Democratic Party.

\footnotetext{
${ }^{25}$ ALN, Segreteria Speciale, Folder 1963/III, "Letter from Botteri to Muratti," October 8, 1963.

${ }^{26}$ ASL, Fondo Mario Scelba, Versamento II, Corrispondenza, B.17, f.199, "Scelba to Bartoli," October 23, 1963.

${ }^{27}$ ACS, MI, Gabinetto, Schedario Partiti Politici 1944-1966, B.113, fasc.1252/P, ANI, "Prefect to Gabinetto," December 6, 1962.

${ }^{28}$ ASL, Fondo Democrazia Cristiana, Segreteria Politica, Moro, Corrispondenza con Organizzazioni Varie, Sc.156, Fasc.34, "Letter from Head of the Association Bastico to Vice-Secretary Salizzoni," February 28, 1963.
} 
Similarly, Prime Minister Amintore Fanfani publicly called for the preservation of irredentist

Nazario Sauro's house in Capodistria, a symbolic act that aimed to both promote the Italian heritage of the ex-zone B and, more importantly, strengthen political support from the émigrés. ${ }^{29}$

To summarize, the Christian Democratic opening to the left provoked a number of political responses that, especially in Trieste, fueled popular hostility toward the local and national governing elites. Not only political parties but also associations opposed the political move which was widely perceived as an advantage to the national and local communists. In particular, the bitter legacy of years of ideological confrontation between movements that had advocated a pro-Italian, pro-Yugoslav, or independent solution to the Triestine problem intertwined with a prolonged socioeconomic crisis that ultimately boosted people's animosity against the central government and its center-left political strategy. The government, however, understood that people both in and outside Trieste were unprepared to move decisively away from past conservative political orientations and, therefore, it needed to proceed cautiously on the new political path.

\section{Resisting the Change: the Émigrés and the Center-left}

While pursuing the experiment of the center-left, the Christian Democratic-led Italian government also had to respond to the request of the émigré associations which feared the further marginalization of the Istrian problem within national public discourse. Being a frontier city, Trieste had been the main crossing point of Yugoslav immigration from Yugoslavia which would significantly decrease between 1963 and $1967 .{ }^{30}$ In 1963, the Italian government decided to extend the status of émigrés only to ethnic Italians who were living outside the ex-zone B and were able to prove their loyalty to the Italian state. This decision also required the incoming refugees of the exzone B to prove they had opted for Italian citizenship after 1945 or possessed adequate knowledge of Italian language to be granted the status of émigrés.

\footnotetext{
${ }^{29}$ ACS, PCM, Busta 36, Fasc. L3, "Ufficio Consigliere Diplomatico,” 1963.

${ }^{30}$ UZC, Sezione II, Fondo Trieste, Busta 55, Vol. II, Folder prospetto statistico profughi, 1963-1967.
} 
Patriotic, veteran, religious, and, above all, émigré associations along with members of the local Christian Democrats firmly protested against this new law. ${ }^{31}$ Not only did it overlook the problematic exercise of citizenship rights for Italian residents under Yugoslav administration after 1945, but it also disregarded the fact that the lack of knowledge of the Italian language among many residents was a direct consequence of the post-war Yugoslav policy of de-Italianization. Recognizing the merits of such criticism, local Commissioner Libero Mazza, head of the Government Bureau for the Friuli Venetia Julian Region which had replaced the General Italian Government for the Free Territory of Trieste (CGGTT) as the new local state authority in 1963, proposed that the central government conduct individual investigations to better determine the ethnicity and national sentiments of the incoming émigrés. ${ }^{32}$

Istrian philanthropic associations also called upon the central government to promptly extend Italian citizenship to the émigrés who had been forced to leave because of their Christian faith. A more inclusive measure, they argued, could have finally put an end to the social "ghettoization" of the incoming Istrians, accelerated their re-integration within the national community, and removed widespread prejudice within segments of local and national public opinion which had long labeled the émigrés as unrepentant fascists. ${ }^{33}$ The Istrian C.L.N., eager to disprove such prejudices and stereotypes, cooperated with the national government by providing detailed reports on each individual and family who requested Italian citizenship.

To facilitate the recognition of the incoming Italian citizens and reduce the infiltration of anti-Italian sentiments, the government also decided to gather all of the incoming émigrés from the ex-zone B into a single camp in Cremona. Members of the Istrian C.L.N. who had worked as intermediaries between the Italian minority in Yugoslavia and the Italian government also wrote a set of letters to the members of the Italian government in which they supported the émigrés' return

\footnotetext{
${ }^{31}$ UZC, Sezione II, Fondo Trieste, Busta 56, Vol. II, Folder gestione campi profughi da parte dell'A.S.I."CGGTT to PCM, clandestini dalla Jugoslavia," July 6, 1963.

${ }^{32}$ UZC, Sezione II, Fondo Trieste, Busta 56, Vol. I, Folder afflusso clandestini dalla Jugoslavia respingimento profughi ineligibili, "Confidential Note CGGT to PCM, respingimento di profughi ineleggibili di cat. A," January $14,1964$.

${ }^{33}$ UZC, Sezione II, Fondo Trieste, Busta 56, Vol. I, Folder afflusso clandestini dalla Jugoslavia respingimento profughi ineligibili, "Società Operaia di Mutuo Soccorso Albona to President of Council Moro," March 10, 1964.
} 
to Italy. In these letters, they stressed the bureaucratic impediments and widespread violence against the Italians in Yugoslavia who attempted to exercise the right to opt for Italian citizenship after 1945. The C.L.N. members argued that, although the émigrés had been stripped of their properties and belongings, as best symbolized by the metaphor of the "focolare" or "household fireplace," the sentimental attachment to their native Istria remained unbroken as well as the faith in the righteousness of their cause. ${ }^{34}$

In their correspondence to the central government, the Istrian associations complained that only $41 \%$ of the incoming refugees from the Yugoslav territory were granted the status of émigrés despite their efforts. In response, the central government decided to ease the immigration procedure for members of the former Italian community in Yugoslavia. At the same time, it also highly restricted the flow of non-Italian Yugoslav citizens who represented about $90 \%$ of the total immigrants in Italy from Eastern Europe between 1960 and $1966 .{ }^{35}$ Nonetheless, the presence of Italian and Yugoslav citizens across the provisional border remained a source of tension that further strained political relations between the Italian and Yugoslav governments. For example, between 1965 and 1968, about fifty Yugoslav citizens illegally tried to enter Italian territory and were arrested. In addition, a few incidents between Italian and Yugoslav guards occurred across the demarcation line and Yugoslav authorities also arrested fifty Italian citizens on accusations of espionage. These episodes provoked the vibrant protest of the Italian government. ${ }^{36}$ At the same time, however, Belgrade accused the Italian government of providing shelter to a widespread antiTitoist network that in Italy, especially in Trieste, was led by the Cetnik movement and aimed to overthrown Tito's regime. ${ }^{37}$

\footnotetext{
${ }^{34}$ UZC, Sezione II, Fondo Trieste, Busta 56, Vol. I, Folder afflusso clandestini dalla Jugoslavia respingimento profughi ineligibili, "Confidential CGGTT to PCM, profughi provenienti dall'ex zona B," March 23, 1964.

${ }^{35}$ UZC, Sezione II, Fondo Trieste, Busta 56, Vol. I, Folder afflusso clandestini dalla Jugoslavia respingimento profughi ineligibili, "MI to MAE, afflusso profughi dalla Jugoslavia," February 9, 1967.

${ }^{36}$ UZC, Sezione IV, Busta 28, Vol.I, Folder arresto Floriano Antonio e altri, "Correspondence MAE-PCM," $1965-1967$.

${ }^{37}$ ACS, MI, Gabinetto, Fasc. Correnti, 1964-1966, B.246, Notizie Jugoslavia, Fasc. 15085/3, Folder associazioni slovene varie, "Confidential Note to PCM," May, 1963.
} 
In a telegram from November 1963, however, the Yugoslav government clearly stated its intention "to transform the Italian minority of the ex-zone B into the human face of the reconciling dialogue between Adriatic border communities. ${ }^{, 38}$ Despite the Yugoslav claims, mutual suspicion still firmly pervaded political relations between the Adriatic neighbors and good intentions often remained on paper. Indeed, even after 1963, the Italian delegates to the joint Italian-Yugoslav committee for minorities continued to raise the issue of Yugoslav discrimination toward both the Italian culture and the political rights of the Italian minority in the ex-zone B. In response, the Yugoslav representatives stressed that the Slovene community in Trieste was a victim of judicial and educational mistreatment, a situation that violated the terms of the London Memorandum. ${ }^{39}$

To counter the Italian state's complaints over the mistreatment of the Italian residents of the ex-zone B, the Yugoslav government used Radio Capodistria and its program "Neighbor Regions and their People." Through this medium, Belgrade argued that by publishing the legal statute establishing the new autonomous region in 1963 only in the Italian language, the Italian government had not only ignored the requests of the local Slovene community but also violated the spirit of the London Memorandum. ${ }^{40}$ In addition, the radio station also reported any episode of ethno-political intolerance that proved the survival of irredentist and fascist views among the local Italian population. Acts of vandalism against Slovene monuments and local skirmishes between Slovenes and Italians were usually attributed to the initiatives of "fascist bad boys." 41

These criticisms from Belgrade were often echoed in the words of local Triestine political formations, especially the Communist Party and the pro-independence youth socialist associations. ${ }^{42}$ These associations attacked the de-nationalizing nature of the Italian administration's policies and presented themselves as a bridge to young Slovenes across the demarcation line. ${ }^{43}$ While supporting the grievances of local Slovenes, Italian Socialists and the Independence

\footnotetext{
${ }^{38}$ MAE, Telegram 35385, "Belgrade to Rome," November 23, 1963.

${ }^{39}$ ACS, PCM, Ufficio Consigliere Diplomatico, Busta 66, Sfasc.1, “Comitato Misto,” December 12, 1963.

${ }^{40}$ UZC, Sezione II, Fondo Trieste, Busta 46, Folder trasmissioni Radio Capodistria, 1963-1964.

${ }^{41}$ MAE, Telegram 27717, Vol.44, "Belgrade to Rome," September 13, 1963.

42"Cercasi referenze per italianità," L'Unità (February 15, 1963).

${ }^{43}$ UZC, Sezione IV, Busta 36, Folder iniziativa giovanile Circolo Sloveno, 1962-1963.
} 
Movement also enthusiastically embraced the experiment of the center-left. This new political alignment, which was also welcomed by Belgrade, represented an outstanding opportunity to significantly advance political and economic relations with Italy. ${ }^{44}$ In addition, the Commissioner of the Italian Government in Trieste, Libero Mazza, reassured Prime Minister Moro that the new course of both Italian domestic and foreign policy could effectively serve as an antidote against the recurrent episodes of socio-political discrimination towards the Slovene minority and a unique opportunity to consolidate the Adriatic friendship. ${ }^{45}$ Despite such confidence, both the émigrés and Triestines continued to perceive Tito's regime in a negative light and looked with increasing suspicion to a political rapprochement with the Communist dictator.

Thus, the official announcement of Moro's visit to Yugoslavia inflamed local criticism of the Roman governing elites. Bishop Santin wrote Moro, stating that his initiative would pave the way for Tito's future visit to Italy and offended the feelings of many Italians "who loved their homeland without being nationalists." 46 Santin argued that the indifference of the government to the continuous Yugoslav violations of religious freedom, violence against Italian fishermen in Yugoslav territorial waters, and the widespread discrimination against the Italian minority of the exzone B greatly fed the hostility of the city toward Tito. In an attempt to reassure Santin, Moro responded that his visit to Yugoslavia aimed at the protection of the Italian minority by consolidating diplomatic relations with the Yugoslav regime.

In 1964, however, the presence of signs denoting the Yugoslav state's borders rather than the demarcation line between the ex-zones A and B of the Triestine territory produced vigorous protests among the émigrés. Above all, it required the Italian government to show firmness against what was locally perceived as symptomatic of Yugoslav territorial ambitions. Thus, the Italian government accused Belgrade of disregarding the provisional status of the demarcation line and

\footnotetext{
${ }^{44}$ ACS, PCM, Ufficio Consigliere Diplomatico, Busta 66, Sfasc.2, "Ducci to Pompei," January 8, 1964.

${ }^{45}$ UZC, Sezione IV, Busta 11, Folder Lega Economica Culturale Slovena, "Confidential Mazza to PCM, attività Lega Slovena," February 5, 1964.

${ }^{46}$ ACS, Carte Moro, Presidenza del Consiglio dei Ministri 1963-1968, Busta 77, Sottofasc. Visita in Jugoslavia 8-12 Nov. 1965 corrispondenza precedente alla visita 1964, “Correspondence Moro-Santin,” December 30-January 9, 1964.
} 
reasserted the claim of Italian sovereignty over the northern part of the Istrian region. This decision was motivated by the awareness that any renunciation of sovereignty over the ex-zone B "could inflame the Italian nationalist environment which was already opposed to any concession to the Slovene minority. ${ }^{" 47}$ Although the sign dispute temporarily strained Italian and Yugoslav diplomatic relations, both governments still decided to discuss further economic and political cooperation during Moro's visit.

By clearly reaffirming its strict opposition to any change in the formal status of the ex-zone $\mathrm{B}$, the Italian government won the sympathy of both émigrés and significant segments of the conservative national press. Newspapers such as Il Giornale d'Italia hoped that new bilateral agreements would improve the lives of the minute Italian minority still living in the ex-zone B and accelerate Trieste's economic recovery. According to the newspaper, a prosperous Trieste, while becoming the new center of both Adriatic "Italianità" and Western ideals of liberty, could ultimately expose the dictatorial nature of Tito's regime. ${ }^{48}$

These arguments, while aligned with the leading views of both the governing elites and national public opinion, further confirmed the gradual weakening of irredentist rhetoric. Indeed, a wealthy Trieste, rather than the reincorporation of its former territory, would better serve the preservation of the Italian identity of the border and, at the same time, work as a barrier to Yugoslav Communism. Over time, the territorial reincorporation of the ex-zone B had indeed disappeared from the diplomatic agenda of the central government and, especially after 1963, any reference to this issue was increasingly perceived as a "needless element of contentiousness amid the Adriatic friendship."49

\footnotetext{
${ }^{47}$ ACS, Carte Moro, Presidenza del Consiglio dei Ministri 1963-1968, Busta 77, Sottofasc. Visita in Jugoslavia 8-12 Nov.1965 , "Notes to Moro," February, 1964.

${ }^{48}$ Giuseppe dell'Ongaro, "Capodistria somiglia ancora a Venezia," Il Giornale d'Italia (April 23, 1964).

${ }^{49}$ ACS, Carte Moro, Presidenza del Consiglio dei Ministri 1963-1968, Busta 77, Sottofasc. Visita in Jugoslavia 8-12 Nov. 1965, "Berio to Saragat," March 31, 1964.
} 
Meanwhile, the émigré associations continued to criticize the "fanatic opening" of the Christian Democrats to the political left. ${ }^{50}$ Also a few Italian committees still operating in the exzone B, while praising Moro for his past defense of Italian sovereignty over the Istrian region, expressed concern for the accommodating behavior of the Italian government toward Yugoslavia. Therefore, the association asked the national government to not renounce formally any sovereign rights to the ex-zone $\mathrm{B} .{ }^{51}$ This emphasis on the preservation of the territorial status quo and the protection of the linguistic and cultural right of the Italian residents of the ex-zone B exposed a gradual sense of discouragement that, in recognizing the abandonment of the former irredentist goal of winning back the Istrian region, was gradually consuming the Adriatic associational network.

Neo-fascist propaganda, for its part, unrepentantly used nationalist arguments to undermine the new Adriatic détente which favored "the expansionist ambitions of an uncivilized population."52 In this view, not only the dialogue with the Yugoslav neighbor, but especially the creation of the autonomous region was depicted as a political move that catered to communist and socialist expectations. Due to its acquiescence to the pressure of the leftist parties, the government was accused of passively accepting Yugoslav sovereignty over the Istrian region, the real cause of the city's economic decline. ${ }^{53}$

In confronting the policies of the center-left, the émigré associations repeatedly stressed the image of Trieste as the center of Adriatic "Italianità." This image remained attractive to significant segments of the Triestine community. Above all, similar to the political propaganda of the immediate post-war years, the idea of Trieste as a symbol of national patriotism and independence from Austrian Imperial rule became a useful tool for both right and left-wing political parties. While celebrating the patriotic sacrifice of nationalist figures such as Guglielmo Oberdan and Nazario

\footnotetext{
${ }^{50}$ ASL, Fondo Democrazia Cristiana, Segreteria Politica, Rumor, Corrispondenza Organi Periferici, Sc.177, Fasc.1, s.fasc.4, "Bartoli to Rumor," March 23, 1964.

${ }^{51}$ AUI, Miscellaneous, Folder Corrispondenza con Personalità del Governo 1961-1973, "Comitato Familie Zona B to Moro," May 7, 1964.

${ }^{52}$ Claudio Cesaretti, "Friuli-Venezia Giulia uniti contro l'Italia," Il Borghese (May 7, 1964).

${ }^{53}$ Felice La Rocca "La regione Friuli Venezia Giulia e i suoi gravi problemi economici," Il Secolo d'Italia (May 7 , 1964).
} 
Sauro as well as socialist figures such as Cesare Battisti, opposing political formations rhetorically portrayed the defense of Trieste's Italian identity as a problem of liberty and independence. ${ }^{54}$

In their campaign for the ex-zone B and against the new policy of the center-left, the émigrés were supported by the National Italian Irredentist Association (ANII) which advocated the creation of a single national front. ${ }^{55}$ Its proposal was received with enthusiasm by many patriotic and veteran associations which displayed their solidarity with the irredentist cause and proved willing to coordinate their actions. ${ }^{56}$ Despite this, the support of neo-fascist groups for the initiative of the ANII discouraged other organizations from joining the national front. These groups, identifying themselves with the adventurism of the Fiume expedition, exposed the negative effects of fascist views over the border. ${ }^{57}$ The ANII, repeatedly criticized by other émigré and patriotic formations for its unrepentent fascist views, responded to such accusations by claiming that members of the National Venetia Julia and Dalmatia Association were acquiescing to the directives of the Christian Democrats and ultimately weakening Italian formal claims over the ex-zone B. ${ }^{58}$ Although internal disagreements had long characterized the Adriatic associational network and adversely affected its propaganda, both émigré and patriotic associations had traditionally agreed on the irrepressible defense of Italian formal claims to the ex-zone B. Indeed, in September 1964, when Tito declared in Lissa that the zone B was Yugoslav territory, the National League and the émigré associations promptly requested that the Ministry of Foreign Affairs make an official statement in defense of Italian territorial sovereignty. Partially in response to these complaints, President Saragat denied any changes to the provisional status of the demarcation line. ${ }^{59}$

Over time, the demarcation line's judicial status had become an object of public misinformation and had been often treated as a part of the Yugoslav federation. For example, the

\footnotetext{
${ }^{54}$ Vittorio Parmentola "Irredentismo e democrazia", Il Pensiero Mazziniano (July 25, 1966).

${ }^{55}$ AUS, Fondo Luigi Papo, Busta 33, Fasc. Associazioni Combattentistiche, "President Italia Irredenta to all exCombatant Associations," March 19, 1964.

${ }^{56}$ AUS, Fondo Luigi Papo, Busta 33, Fasc. Associazioni Combattentistiche, d'Arma, e Patriottiche, "Correspondence," 1964.

${ }^{57}$ ACS, MI, Divisione Affari Riservati, 1957-1960, B. 215, Folder "Gruppi d'Azione D’Annunziana," Fasc.3, "Confidential Report from Prefect of Florence," December 20, 1965.

${ }^{58}$ AUS, Fondo Luigi Papo, Busta 34, Fascicolo ANVGD, "Papo to ANVGD," May 13, 1964.

${ }^{59}$ Claudio Cesaretti, "A Tito quel che non è di Tito," Il Borghese (March 11, 1965).
} 
geographical maps within the Encyclopedia Universo neglected the existence of the ex-zone B yet depicted the ex-zone A as an area outside the Italian borders. The bilingual toponomy of the exzone B was also partially ignored and the Istrian exodus barely mentioned. The National League, therefore, firmly protested and demanded the correction of these mistakes, reiterating the association's campaign for defense of the status quo of the Adriatic border. ${ }^{60}$ It also invited national newspapers and magazines to undertake a campaign about both the Triestine problem and the perpetual Yugoslav threat to the Eastern border. $^{61}$

Right-wing journals promptly responded to the appeal of the local patriotic and émigré associations. On the tenth anniversary of the return of Italian administration to Trieste, the rightwing press employed derogatory language toward the local Slovene minority and harshly criticized the new policies of the center-left coalition for both the local economic crisis and the demise of local patriotism which had ultimately made Trieste a "childless city." ${ }^{62}$ By contrast, the most progressive fringes of local public opinion celebrated the London Memorandum as an "act of political courage that violated the sentiments of the Italian population yet removed nationalist antagonism." ${ }^{63}$ This interpretation, however, only partially applied to the specificity of the Triestine context. During the local demonstrations of 1964, a group of about a hundred right-wing students marched against the separation of the city from its Istrian territory and were later disbanded by the local police. ${ }^{64}$

These local sporadic expressions of nationalism certainly discredited the émigré campaign in support of the ex-zone B and, within national public opinion, weakened political support for it. Above all, the émigré campaign strained diplomatic relations between Belgrade and Rome. The political debate that anticipated the first Istrian national meeting of November 3 and 4, 1964 in Trieste revealed the complexity of this issue. Foreign Minister Giuseppe Saragat, fearing Belgrade's

\footnotetext{
${ }^{60}$ ALN, Segreteria Riservata, Folder 1964/II, "Muratti to Editor Universo," November 30, 1964.

${ }^{61}$ ALN, Segreteria Riservata, Folder 1964/II, "Muratti to Editor Epoca," September 8, 1964.

${ }^{62}$ Gianni Preda, "Requiem per Trieste," Il Borghese (July 23, 1964).

${ }^{63}$ Giorgio Cesare, "Dieci anni dopo il 26 Ottobre 1954," Trieste (September-October, 1964).

${ }^{64} \mathrm{UZC}$, Sezione IV, Busta 51, Folder manifestazione di studenti a Trieste, "Telegram from Mazza to MI," October 7 , 1964.
} 
reaction, firmly opposed the government's financial support for the Istrian National Convention. ${ }^{65}$ Initially, both local authorities and the "Morotei" leadership of the Christian Democrats had also agreed to postpone the Istrian convention for political reasons. However, Commissioner Libero Mazza, who was concerned about a possible backlash in the upcoming elections, ultimately agreed to host the event and participated in it. ${ }^{66}$

Although the Istrian CLN, which was increasingly aligning itself to the government's views toward Tito and openly disputing the political views of the other émigré associations, refused to attend the event, the convention had a strong symbolic impact on the émigré community. ${ }^{67}$ In his speech, Bartoli invited his "Istrian brothers" to bury their feelings of resentment and desire for vengeance for the unfortunate fate of their region and, instead, communicate their hopes for a peaceful revision of the unjust peace treaty to the central government without being tempted by political extremism. ${ }^{68}$ These arguments were also echoed by a variety of ex-combatant associations. ${ }^{69}$ Those that showed strong democratic leanings could count on the active support of leading Christian Democratic figures such as Giulio Andreotti and represented about 495,000 soldiers. ${ }^{70}$ These associations, while espousing Italian sovereignty over the territories of Istria and Dalmatia, also showed an ambivalent attitude toward the experiment of the center-left.

On the other hand, Socialists and Social Democrats supported this new political configuration and its correlated policy of peaceful coexistence with the Yugoslav neighbor. ${ }^{71}$ In order to maintain good bilateral relations with Tito's Yugoslavia, the government sought to minimize the visibility of the most overtly neo-irredentist associations during the November 4, 1964 celebration of national independence from Austria-Hungary which coincided with the Istrian

\footnotetext{
${ }^{65}$ ACS, PCM, Ufficio Consigliere Diplomatico, Busta 58, “Unione Istriani,” October, 1964.

${ }^{66}$ ACS, MI, Dipartimento della Pubblica Sicurezza, Cat.G, Associazioni, 1944-1986, B.363, Folder Unione degli Istriani, "Mazza to PCM," October 8, 1964.

${ }^{67}$ ACS, MI, Dipartimento della Pubblica Sicurezza, Cat.G, Associazioni, 1944-1986, B.363, Folder Unione degli Istriani, "Mazza to PCM," October 13, 1964.

${ }^{68}$ AST, Fondo Bartoli, Busta 4, Discorsi, 1964.

${ }^{69}$ AUS, Fondo Luigi Papo, Fasc. 68, 36 "I raduno nazionale degli istriani," 1964.

${ }^{70}$ ACS, MI, Divisione Affari Riservati, 1957-1960, B. 167, Folder Nastro Azzurro, "Report from Prefect of Gorizia," November 12, 1964.

${ }^{71}$ Bucarelli, ed. Garzia (2011), 134.
} 
convention in Trieste. Thus, the National Italian Irredentist Association (ANII) was prohibited to walk up the "Altare della Patria" (Altar of the Fatherland) and display its flag in Rome. Addressing this episode, the right-wing press accused the Christian Democrats of marginalizing not just the ANII but also the border issue within public discourse. ${ }^{72}$ In a letter to Christian Democratic leader Fanfani, Saragat exposed the government's views on this issue by stating that "popular expressions of irredentism had to be firmly discouraged."73

As the central authorities expected, the Triestine demonstration of November 4 was harshly criticized by Yugoslav observers who depicted Bartoli's speech as a clear example of Italian irredentism. ${ }^{74}$ Fearing that similar demonstrations would impede the ongoing process of diplomatic normalization with the Yugoslav neighbor, the government would later refuse to authorize the second Istrian national convention of $1966{ }^{75}$ This decision, resolutely criticized by the émigré community in Trieste, further reinforced local beliefs that the center-left government had definitively abandoned the defense of Italian claims over the ex-zone B because it had become a sore spot in the new relationship with Tito's regime. ${ }^{76}$

\section{5: the "Great Divergence"}

As discussed in the previous sections, the new center-left coalition government and its policy toward Yugoslavia produced significant opposition to the Christian Democrats in Trieste, especially among members of the émigré community who feared Italian formal recognition of Yugoslav sovereignty of the ex-zone B. In order to advance political and economic relations with the Yugoslav neighbor, Prime Minister Aldo Moro understood that the Istrian problem effectively

\footnotetext{
${ }^{72}$ AUS, Fondo Luigi Papo, Busta 9, fasc.70, "Manifestation," November 4, 1964.

${ }^{73}$ ASR, Sezione IV, Fanfani Diari, "Discussion with Saragat,” December 30, 1964.

${ }^{74}$ ACS, MI, Dipartimento della Pubblica Sicurezza, Cat.G, Associazioni, 1944-1986, B.363, Folder Unione degli Istriani, "Italian Embassy in Belgrade to PCM," November 28, 1964.

${ }^{75}$ ACS, MI, Dipartimento della Pubblica Sicurezza, Cat.G, Associazioni, 1944-1986, B.363, Folder Unione degli Istriani, "Malagodi to PCM," September 7, 1966.

76،“Un'amara protesta dell’Unione: gli istriani costretti a sospendere il raduno," Il Piccolo (October 10, 1966).
} 
required a final settlement. In 1965, Moro's visit to Yugoslavia seemed an outstanding opportunity to remove this burden from the government's agenda in foreign policy.

In a confidential note to newly elected President Giuseppe Saragat, the Italian Ambassador to Belgrade, Roberto Ducci, confirmed that the Yugoslav government expected Italy to formally recognize Yugoslav sovereignty of the ex-zone B during Moro's upcoming trip. While defining the Istrian problem as politically and militarily irrelevant, Ducci merely recognized its historic and political value and optimistically predicted the negotiations to conclude by June 1965 . According to the Ambassador, the prospective agreement would require the abandoning of any Italian territorial claim to the Istrian region; therefore, he suggested to Saragat that the Italian government propose a "package deal" or global negotiation in which Italy would receive significant compensation for renouncing its formal sovereignty over the ex-zone $\mathrm{B} .^{77}$

In his proposal, Ducci clearly stated that “Trieste's economic suffocation was a direct consequence of the territorial losses caused by both the Paris Peace Treaty and the London Memorandum.” For these reasons he believed that, while waiting for the inevitable Italian recognition of Yugoslav formal sovereignty over the ex-zone B, diplomatic negotiations and economic agreements should proceed in order to improve Trieste's economy. Ducci advised Saragat to include a new fishing agreement, clauses on property indemnities, and guarantees for minority rights within the "global package." Above all, Ducci believed that the Italian government should persuade the Yugoslav leadership to extend the protection of minority rights for the local Italian community of Capodistria to cities such as Fiume and Pola. ${ }^{78}$

Although Ducci's proposal well mirrored the views of the majority of the Christian Democrats, a secret report from the Italian Military Intelligence Service discouraged the central government from making any definitive settlement over the border and stressed the fickle nature of

\footnotetext{
${ }^{77}$ Bucarelli, ed. Garzia (2011), 140.

${ }^{78}$ Fondazione Nenni (FN), Carte Nenni, B.60, Sez. C 1961-1969, "Ducci to Saragat," December 1, 1964.
} 
Triestine public opinion. ${ }^{79}$ Moro, reassured by a telegram from Ducci who confirmed that Belgrade understood the Italian government's unwillingness to formally renounce sovereignty over the exzone B at that political moment, suggested to Foreign Minister Fanfani that he remove all territorial issues from the agenda of the Belgrade meetings. ${ }^{80}$

This exchange of letters explains the government's decision to not proceed with the definitive settlement of the border dispute in 1965. It also reveals that, by the mid-1960s, the political will of the central government did not correspond with the wishes of the majority of the Triestine population and the émigrés, who were still reluctant to formally surrender Italian formal rights on the Istrian region once and for all. Thus, after 1965, in order to facilitate the formal renunciation to claims over the ex-zone B and minimize its political costs, the central government provided significant financial support to the Triestine cultural circles that promoted social reconciliation between local Italians and Slovenes. ${ }^{81}$ At the same time, it also continued to finance patriotic associations that had traditionally provided support for the Christian Democrats. ${ }^{82}$ Discussing the central government's strategy, Sergio Coloni, vice-secretary of the Triestine Christian Democrats, argued that the gradual democratization of Triestine society would not only weaken local expressions of nationalism but also promised to politically isolate the Communist Party. $^{83}$

Although promising, this strategy would greatly depend on the central government's ability to preserve the cultural and linguistic Italian identity of Trieste while concurrently strengthening its local economy. Indeed, the restoration of Trieste's past economic prosperity would ultimately strengthen local support for the Christian Democrats, the center-left coalition, and the process of Adriatic detente. In the 1965 economic context, however, the National League reported to officers

\footnotetext{
${ }^{79}$ ACS, Carte Moro, Presidenza del Consiglio dei Ministri 1963-1968, Busta 77, Fasc. Visita ufficiale in Jugoslavia Presidente del Consiglio On. Prof. Aldo Moro (8-12 novembre 1965), "SIFAR Ufficio "S" Jugoslavia, note di politica interna ed estera e notizie militari," January 27, 1965.

${ }^{80}$ ASR, Sezione IV, Fanfani Diari, "Moro to Fanfani," March 16, 1965.

${ }^{81}$ UZC, Sezione V, Busta 26, Vol.I, Folder circoli Studi Sociali "G. Salvemini," "Contributions 1965-1972."

${ }^{82}$ ASL, Fondo Democrazia Cristiana, Segreteria Politica, Rumor, Corrispondenza con il Governo, Sc.181, Fasc.2,

"Bastico to Rumor," February 8, 1965.

${ }^{83}$ DT, Fondo Coloni, B.3, Coloni's speech, May 15, 1965.
} 
of the Italian foreign affair ministry that people in Trieste understood the new course of Italian foreign policy toward Yugoslavia as a threat not only to the city's Italian identity but also to its local economy. ${ }^{84}$

Local apprehension spiked in February 1965 when the French journal Combat published an article that claimed to expose the existence of secret negotiations between members of the Italian foreign ministry and the Yugoslav government for the definitive recognition of Yugoslav sovereignty over the ex-zone B. In response, the right-wing press, recalling the 1964 dispute over border signs, pointed to Rome's diplomatic weakness and its ambiguous defense of the provisional status of the demarcation line. ${ }^{85}$ It also added that the ongoing marginalization of Istria and Dalmatia within public discourse catered to the wishes of a governing elite that was eager to silence the neo-irredentist network. ${ }^{86}$

In opposition to the government, the neo-fascist M.S.I. demanded that Italian claims over the ex-zone B be upheld. Its representatives called upon the local Triestine council to support a popular plebiscite which would be held under the supervision of the UN and open to all who had resided in the area prior to June 1940. This proposal rested on traditional arguments of uninterrupted Italian territorial sovereignty over Istria and the fact that the London Memorandum had never been ratified by the national Parliament. As time passed and the exodus continued, MSI's Ferfoglia argued, "the issue was becoming increasingly relevant and required government action to avoid the loss of a territory whose economic rather than sentimental value represented an indispensable tool to recover Trieste's prosperity."

The Christian Democrats, however, had abandoned the idea of a plebiscite already in 1954. They believed that such an idea was senseless, especially when considering the mass migration of the émigrés, and, therefore, thought it could be detrimental to the good standing of Italian-Yugoslav relations. Local Socialists such as Bruno Pincherle also condemned the neo-fascist proposal. In a

\footnotetext{
${ }^{84}$ ALN, Folder 1965/II, Segreteria Riservata, "Lega to Ministry of Foreign Affairs," January 16, 1965.

85 “Il governo vuol cedere la zona B a Tito," Il Secolo d'Italia (March 4, 1965).

${ }^{86}$ Claudo Cesaretti, "Irredentismo difficile," Il Borghese (April 29, 1965).

${ }^{87}$ ACT, Verbale Consiglio Comunale, "Allegato 5,” June 4, 1965.
} 
speech in 1965, Pincherle claimed that the Italian-Yugoslav border should be emptied of rivalry and antagonism and instead transformed into a point of "osmosis of different cultures and economies." By metaphorically drawing this border with a pencil instead of a pen, the Socialist leader advocated the dissolution of the artificial frontier into a "space of brotherhood, equality, and freedom." 88 This argument in support of socio-political reconciliation across the border well reflected the views of the majority of Italy's political establishment which considered the ex-zone B as an integrant part of Yugoslavia; the issue, however, could still inflame the sentiments of the émigrés. Above all, Italians in Trieste continued to read the city's frontier identity through the lenses of the Cold War and responded to changes in local politics accordingly.

\section{The Hrescak Case}

In the mid 1960s, Pincherle's hopes for an open border greatly depended on the successful transformation of people's attitudes and views. The Christian Democrats' decision to appoint Dusan Hrescak, a Slovenian Socialist with a Titoist past, as a local administrator, fueled local hostility. ${ }^{89}$ This issue, which became known as the Hrescak case, was generally perceived by patriotic and émigrés associations as well as the most conservative fringes of the local Christian Democrats as the result of a politically premature move. ${ }^{90}$ Since 1963 , both the National League and the "Unione Istriani” (Istrian Union) had contended that the appointment of Slovene representatives in prominent roles inside the local council would endanger the Italian identity of Trieste and overlooked the political responsibility of Slovene communist leaders in the process of deItalianization of the Istrian region. ${ }^{91}$ In claiming that representatives of Titoist and pro-

\footnotetext{
${ }^{88} \mathrm{ACT}$, Verbale Consiglio Comunale, "Allegato 5," June 11, 1965.

${ }^{89}$ “Conseguenza della svolta politica determinatasi al Municipio," Il Piccolo (July 24, 1965).

${ }^{90}$ Silvano Drago, "Un uomo di Tito nella Giunta Comunale? Un affronto e un pericolo che Trieste non potrebbe tollerare," Difesa Adriatica (July 5-12, 1965).

${ }^{91}$ AUI, 1954-1967, Busta 5, Folder III/7, "Unione Istriani to Botteri," October 7, 1963.
} 
independence political orientations threatened Trieste's Italian cultural and linguistic heritage, these associations ultimately aimed to defy the experiment of the center-left. ${ }^{92}$

Partially echoing these arguments, Republican newspapers such as Il Pensiero Mazziniano argued that the Christian Democrats' choice of Hrescak “enraged Trieste's national sentiments."93 In choosing a Slovene personality who had cooperated with Tito's regime, Il Secolo argued, the Christian Democrats "offended the memory of the victims of Yugoslav wartime retribution." "94 By contrast, leftist parties welcomed the Christian Democrats' decision as a first step in progressively distancing themselves from political formations that, while embracing conservative and nationalist orientations, exacerbated ethno-political and social animosity against the Slovene minority. ${ }^{95}$ In an interesting entry in the local magazine "Trieste," Carl Schiffrer also stated that the Triestine population now had to detach itself from past irredentist interpretations of the city's "Italianità." Schiffrer argued that these views badly fit both the political and economic needs of the city as well as its gradual democratization. ${ }^{96}$

The Hrescak case provoked local demonstrations with a pronounced irredentist tone. ${ }^{97}$ The political confrontation between Italians, Slovenes, and the local police resulted in skirmishes in which 73 people were arrested. ${ }^{98}$ The local neo-fascist movement decisively contributed to fomenting public disorder and further exposed its chauvinist nature. ${ }^{99}$ The Yugoslav authorities promptly condemned the incidents as well as the attitudes and behavior of significant segments of Italian national and local public opinion. ${ }^{100}$ In line with Yugoslavia's reproach, the local Communist

\footnotetext{
${ }^{92}$ ACS, MI, Gabinetto, Fasc. Correnti, 1961-1963, B.81, Fasc. 12010/85, “Attività dei partiti, Trieste,” October 13, 1963.

${ }^{93}$ Giuseppe Tramarollo, “L'errore nazionalista," Il Pensiero Mazziniano (September 25, 1965).

94 “Tutta Trieste condanna l'infamia voluta dalla DC," Il Secolo (July 24, 1965).

${ }^{95}$ ACT, Verbale Consiglio Comunale, "Allegato 3," July 22, 1965.

${ }^{96}$ Carl Schiffrer, "È ad una svolta la politica democratica al confine orientale," Trieste (May-June, 1965).

${ }^{97}$ Vezzà and Comelli, 109.

${ }^{98}$ ACS, MI, Gabinetto, Fasc. Correnti, 1964-1966, B.79, Fasc. 12010/85, Attività dei partiti, "Telegram from Mazza to PCM," July 31, 1965.

${ }^{99}$ AFG, Fondo Apc, RP, MF0524, p.3166, "Federazione Triestina PC," August 5, 1965.

${ }^{100}$ MAE, Telegram 22114, Vol.43, "Belgrade to Rome," August 2, 1965.
} 
Party also criticized right-wing parties, patriotic associations, and the local Church, whose instrumental use of Hrescak's past had served neo-fascist propaganda. ${ }^{101}$

Meanwhile, the National League with the support of the Istrian associative network collected 42,000 signatures to protest Hrescak's appointment inside the local administration. ${ }^{102}$ Although these numbers were lower than expected, they still proved the endurance of conservative views within the Triestine community. Above all, Hrescak's appointment stimulated an internal debate within the National League whose executive committee discussed how to deal with those members who had supported the candidature of the Slovene representative inside the local council. Considering the fact that many relevant local political personalities were also members of the association, this discussion took on particular importance.

As consequence, local Mayor Mario Franzil was accused of violating his duties as a member of the association and was therefore arbitrarily suspended. ${ }^{103}$ Bishop Santin, however, expressed his disapproval of any form of disciplinary punishment taken by the association towards its members. Santin argued that even though Franzil's support for Hrescak's candidacy was wrong, he had complied with the directives of the national Christian Democratic Party. Moreover, Santin wrote to the President of the National League Giusto Muratti, stating that that forgiving Franzil was not simply a Christian duty but also as a political necessity in order to maintain the traditional bonds between the association and the Christian Democratic Party. ${ }^{104}$

In his response to the criticism of the association, Franzil explained that his decision to support Hrescak's appointment responded to the party's policy. The mere political nature of the issue, Franzil argued, freed him from any responsibility toward the association. In discussing his case, the executive committee of the association predicted a possible disengagement from the Christian Democrats who would act in solidarity with Franzil; however, after long debates,

\footnotetext{
${ }^{101}$ Mario Passi, "Appoggiata dalla Curia la campagna sciovinista," L’Unità (August 4, 1965).

${ }^{102}$ ALN, Folder 1965/II, Carteggio Nobile, "Correspondence between Piero Almerigogna, Fameia Capodistriana, and the directive council of the Lega Nazionale," Summer, 1965.

${ }^{103}$ ALN, Folder 1965/I, Giunta Verbali Presidenza 1965, "Verbale 16," July 27, 1965.

${ }^{104}$ ALN, Folder 1965/II, Carteggio Nobile, "Santin to Muratti," July 30, 1965.
} 
Franzil's November resignation was accepted and his membership was withdrawn, regardless of his valuable commitment to the Italian cause of Trieste in the past. ${ }^{105}$

The decision of the National League, which contradicted its self-proclaimed apolitical nature, indeed clashed with the local strategy of the Christian Democrats who aimed to win the support of the anti-Titoist Slovenes who were associated with the Socialist Party. The Hrescak case also created a significant breach between the party and the association which experienced increasing political ostracism from both local and national Christian Democrats. ${ }^{106}$ Above all, it proved the discrepancy between the Christian Democratic leadership and its center-left strategy and the uncompromising segments of the party's popular base. ${ }^{107}$

The correspondence between Franzil and Muratti confirms that many Italians in Trieste generally opposed the inclusion of Slovene personalities inside the local administration, which they viewed as a threat to the Italian cultural and linguistic identity of the city. ${ }^{108}$ Aware of the endurance of these views, right-wing propaganda used the Hrescak case to claim that the deceptive behavior of both national and local governing elites had facilitated the economic, political, and cultural penetration of the Slovene minority over time, a factor that had ultimately weakened Trieste's Italian identity. ${ }^{109}$

In commenting on the Hrescak case, historian Elio Apih argued that popular hostility toward the Slovene representative was the outcome of the complex relationship between Trieste's patriotism and its frontier identity. From the early twentieth century, the Italian state had successfully manipulated Italian patriotism to fulfill its expansionist ambitions. In this process, local hopes for a Danubian Federation made of independent nations were dashed amidst local nationalist and socialist understandings of the idea of the nation. Under Fascism, Apih argued, everything that was not Italian became anti-national. As a result, Risorgimental ideas of patriotism that were

\footnotetext{
${ }^{105}$ ALN, Folder 1965/II, Segreteria Riservata, "Verbale," December 4, 1965.

${ }^{106}$ ACS, MI, Gabinetto, Fasc, Corrrenti, B.102, Fasc.12010/85, Trieste e provincia attività dei partiti, "Botteri to Taviani," April 14, 1967.

${ }^{107}$ Adolfo Coltano, "Guarda a Tito il sindaco di Trieste," Il Borghese (August 12, 1965).

${ }^{108}$ ALN, Folder 1965/II, Segreteria Riservata, "Letter from Franzil to Muratti," September 25, 1965.

109 "Inerte e passivo il governo nella difesa dell'italianità ai confini orientali," Il Secolo d'Italia (October 15, 1965).
} 
centered upon the right of self-determination were drastically minimized until they had disappeared entirely after the war. Apih well understood that the dialectic of the Cold War was directly related to the surviving legacy of aggressive Adriatic irredentism and had boosted local antagonism toward the Slovene minority. ${ }^{110}$ Thus, after 1945, the government's efforts to safeguard the region's Italian heritage while simultaneously facilitating the peaceful coexistence of different cultures in a frontier city like Trieste were bound to contradict each other and generate frustration among the local Italian population.

The conflicting views of associations and parties that had traditionally acted with a single voice in Triestine politics also revealed the complex and multifaceted features of the Hrescak case. Political groups like the Republican Party, for example, recognized the Christian Democrats valuable defense of Trieste's Italian identity. This view, which contained a unique interpretation of the political reasons that drove the Christian Democrats' strategy in Trieste, was also echoed by the Mazzinian Association. Such a perspective, however, clashed with those of the Italian National Irredentist Association. Indeed, its President, Ezio Garibaldi, wrote to Moro, asking the Prime Minister to exercise political pressure and remove the Slovene representative. ${ }^{111}$ Moreover, in a letter to the local Christian Democrat party Secretary Guido Botteri, the National League President Muratti addressed the social and political implications of the Hrescak case. Muratti argued that since the Christian Democrats' goal to isolate the communist party had instead broken the unity of Trieste's Italian bloc, "the Lega had not won but you really lost." 112

The socio-political turmoil of the Hrescak case effectively exposed the strength of political hostility toward the Slovene minority among segments of the local Italian population. It demonstrated that the defense of Trieste's Italian identity not only remained politically significant to its residents, but it also furthered the preservation of conservative notions of "Italianità" which stemmed from the city's irredentist past. Thus, "a sense of sudden nationhood" resurfaced in Trieste

\footnotetext{
${ }^{110}$ Elio Apih, "Patriottismo democratico e patriottismo nazionalista,"Trieste (May-June, 1965).

${ }^{111}$ AUS, Fondo Luigi Papo, Busta 5, fasc.46, "Letter from National Secretary Garibaldi to Moro," November, 1965.

${ }^{112}$ ALN, Folder 1965/II, Carteggio Nobile, "Muratti to Botteri,” December 10, 1965.
} 
and produced high levels of socio-political polarization that exposed the complexity of the city's frontier identity. ${ }^{113}$

\section{After Hrescak: Making Progress with Tito}

After the weeks of tension that accompanied the Hrescak case, the Triestine branch of Italian public television broadcasted a series of lessons whose content, previously approved by the Ministry of Education, was delivered in Slovene. This initiative, which was intended to serve local schools and associations, was enthusiastically received by Slovene families, teachers, and Triestine authorities. ${ }^{114}$ Local Christian Democrats applauded the initiative and actively mobilized in support of granting Slovene children equal opportunity in schools and the use of cultural institutions. In addition, they also declared their opposition to any form of discrimination against the presence of members of the Slovene minority in prominent political positions. Christian Democrat Sergio Coloni claimed that this new set of social and political programs aimed to defy political opponents who were promoting a climate of "apartheid" in Trieste between Slovenes and the rest of the Italian community. ${ }^{115}$

In stark contrast to the opposition from significant elements of the local political class to the proposed introduction of bilinguism in 1961, the political support of the majority of the Christian Democratic governing elite for Hrescak marked a further step in the local process of democratization. Also, important representatives of civil society grew increasingly suspicious of movements that used nostalgic, anti-democratic and populist methods of political mobilization

\footnotetext{
${ }^{113}$ The concept of sudden nationhood has been elaborated by Max Bergholz in his study of post-WWII BosniaHerzegovina and its intercommunal relations. Bergholz argues that nationhood can suddenly emerges at the micro-level and, especially in wartime and post-civil war local communities in response to economic, societal, and cultural transformations. This concept can be profitably employed to better understand phenomena of localized violence against the Slovene minority in Trieste. See Max Bergholz, "Sudden Nationhood: the Mycrodynamics of Intercommunal Relations in Bosnia-Herzegovina After World War II," The American Historical Review 118 (3) (June, 2013): 679-707. ${ }^{114} \mathrm{UZC}$, Sezione IV, Busta 2, Folder Trieste scuole slovene trasmissioni radio, "Commissariato del Governo della Regione Friuli Venezia Giulia (CGRFVG) to PCM," September 29, 1965.

${ }^{115}$ DT, Fondo Coloni, B. 3, Folder Democrazia Cristiana, 1967.
} 
inside and outside of Trieste. This change in people's attitudes eventually forced the neo-fascist party to also drastically change its strategy, at least for the time being. ${ }^{116}$

Already in the early 1960s, Italian public opinion outside of Trieste increasingly perceived the orthodox defense of the city's Italian identity and Italian sovereignty of the ex-zone B as examples of nationalist nostalgia. Thus, Christian Democrats had reason to hope that Moro's visit to Yugoslavia in late 1965 would lead to a definitive settlement of the border issue and would finally put a "nail in the coffin of the Istrian question." 117 Similarly, the Italian communist press celebrated Moro's visit as the outcome of the Communist Party's long-term policy of support for the peaceful coexistence of Italian democracy with Yugoslav socialism. ${ }^{118}$ These views mirrored those of the majority of Italians who, outside Trieste, had come to equate the city's return to Italy in 1954 to the end of the dispute over the Adriatic border. On the other hand, the right-wing press used the November mass celebration of the fiftieth anniversary of the liberation of Trieste and Istria from Austria-Hungary during the First World War to claim that Moro, during his official visit to Belgrade, would secretly pursue the definitive renunciation of the ex-zone B "which had cost numerous lives and sacrifices."119

These arguments played well into the fears of the local neo-irredentist network, above all the National League. In writing to Moro, National League President Muratti reminded him of the Italian state's sovereign rights to the ex-zone B. Muratti argued that although the unfair terms of the Paris Peace Treaty had determined the loss of the Istrian region and its forced de-Italianization, the Italian government was ultimately responsible for the continued Yugoslav discrimination toward its Italian population as well as Yugoslav abuses against "monuments, tombs, and schools which represented the last few symbols of the region's Italianità." Drawing an interesting parallel to Berlin, a city that Moro had visited a few months earlier, Muratti added that the traditional unity of both cities had

\footnotetext{
${ }^{116}$ See Giuseppe Scaliati, Trame nere: i movimenti di destra in Italia dal dopoguerra ad oggi (Genova: Frilli Editori, 2005).

${ }^{117}$ Albertini,20.

${ }^{118}$ Valentino Parlato, "Nuovi rapporti con la Jugoslavia socialista," Rinascita (November 6, 1965).

119،Celebrazione in sordina," Il Secolo (November 5, 1965).
} 
been broken by the proximity of two irreconcilable regimes; however, while "East Berlin was perceived as a foe of the Western world, Tito was one of its best allies." Muratti concluded that in light of such historical contradictions and considering the oppressive nature of Tito's regime, the Italian government should reassert its sovereignty "on lands that are consumed with the blood of Italian martyrs. ${ }^{, 120}$ The rhetorical tone and content of this letter exposed the association's strong sentimental attachment to the Istrian region and well summarized the views of the most conservative segments of the Triestine community. At the same time, it also proved that by 1965 the National League was aware of Tito's international prestige and understood that the geo-political configuration of the eastern border could not be changed; therefore, the provisional status of the exzone B would ultimately be lost or at best, simply preserved.

Meanwhile, the most extremist fringe of the neo-irredentist movement, best represented by the National Italian Irredentist Association, continued to promote the assertion of Italian territorial rights on the lands lost in the Paris Peace Treaty. In attempting to rally support for Adriatic irredentism, the association organized demonstrations that were often led by dubious figures such as Bruno Coceani and Valerio Borghese. ${ }^{121}$ Its goal was to demonstrate the attractiveness of former irredentist ideals at the national level to the central government and, especially in Trieste, overcome the possible conflicts with the National League which was locally perceived as the main voice of Trieste's "Italianità." After the Hrescack case, however, the National League had dissociated itself from associations whose members showed strong neo-fascist sentiments, including the National Italian Irredentist Association. ${ }^{122}$ Although the National League consciously decided to distance itself from movements or personalities that were part of the neo-fascist movement, it still continued to be considered by the political left as an extremist association in its own right. ${ }^{123}$

The National League, however, gradually aligned itself to the views of the more progressive elements of the émigré associations, above all, the National Julian and Dalmatian Association

\footnotetext{
${ }^{120}$ ALN, Folder 1965/II, Segreteria Riservata, “Letter from Lega to Moro,” September 11, 1965.

${ }^{121}$ Sandro Setta, La destra nell'Italia del dopoguerra ( Roma: Editori Laterza,1995), 213.

${ }^{122}$ AUS, Fondo Luigi Papo, Busta 9, fasc.70, "Bremini to National Secretary ANII," November 3, 1965.

${ }^{123}$ AUS, Fondo Luigi Papo, Busta 9, fasc.70, "Confidential Bremini to Papo," November 5, 1965
} 
(ANVGD). This association, indeed, had long supported the improvement of Italian and Yugoslav diplomatic relations as the best means to protect the rights of the Italian minority across the border. The ANVGD claimed that the Italian government, by supporting cultural exchanges with the Istrian region, also supported Italians in the ex-zone B. Their mistreatment, the association argued, was a "problem of national interest whose resolution relied on the spirit of collaboration that pervaded the Adriatic region before the explosion of nineteenth century nationalisms." ${ }^{124}$ At the same time, the ANVGD also criticized Moro for not treating the economic and the territorial dimensions of the border issue as a single problem, a factor that demonstrated his impaired understanding of the crisis of Trieste's port-driven economy. ${ }^{125}$

The Istrian Union by contrast, maintained an uncompromising attitude toward the issue of the border and called upon Moro to pursue the reintegration of the ex-zone B within Italy's national borders. The association went so far as to suggest an unlikely exchange of territories based on ethnicity. This proposal would not only give Merano to Austria, Istria to Italy, and Carinthia to Yugoslavia but it would also create independent cities in places such as Zara and Fiume. ${ }^{126}$ Moro, however, did not take into consideration any of the aforementioned proposals as they hardly fit with his understanding of the reality of international politics and Italian-Yugoslav bilateral relations. In his meeting with Tito, instead, Moro confirmed the Italian government's willingness to resolve problems of common interest through all-embracing negotiations. ${ }^{127}$

The Christian Democratic turn to the left in 1963 had certainly advanced Italian and Yugoslav diplomatic relations yet mutual suspicions still remained. The Italian government, for example, refused to reissue Italian travel permits to the Yugoslav citizens who had been suspected

\footnotetext{
${ }^{124}$ ACS, Carte Moro, Presidenza del Consiglio dei Ministri 1963-1968, Busta 78, Fasc. Visita in Jugoslavia 8-12 Nov. 1965, Telegrammi, Sottofasc. 5, “ANVGD,” October 28, 1965.

${ }^{125}$ Lucio Burlini, "L’Offensiva jugoslava contro Trieste in contraddizione con il buonvicinato: gli essenziali interessi Italiani in Adriatico vanno difesi," Difesa Adiratica (November 29-December 6, 1965).

${ }^{126}$ ACS, Carte Moro, Presidenza del Consiglio dei Ministri 1963-1968, Busta 78, Fasc. Visita in Jugoslavia 8-12 Nov. 1965, Telegrammi, Sottofasc. 5, "Unione Istriani to Moro,” November 3, 1965.

${ }^{127}$ ACS, Carte Moro, Presidenza del Consiglio dei Ministri 1963-1968, Busta 40, Telegrammi Mnistero Affari Esteri, “Telegramma Segreto 32729," November 10, 1965.
} 
of working as foreign agents. ${ }^{128}$ It also refused to extradite the leader of the Serbian community in Trieste whose anti-Titoist propaganda was harshly condemned by Belgrade. ${ }^{129}$ At the same time, the Yugoslav government still prosecuted and imprisoned Italian citizens for espionage on Yugoslav territory. ${ }^{130}$

Such issues, which produced temporary diplomatic tensions, were often minimized in official talks. For the same reason, the Italian government purposefully avoided any reference to the heated issue of the "foibe." Not only right-wing representatives but also Triestine Communist leader Vittorio Vidali proved very critical of Moro's decision to exclude this issue from his agenda for the Belgrade's meeting. Vidali called up the Christian Democrat leader to make an official statement condemning Yugoslav wartime violence and praising "Italians who had sacrificed their lives for the nation." ${ }^{, 131}$ Similar arguments that pointed to the lingering hostility between the Triestine and Yugoslav Communist parties also revealed the profitability of the political utility of history and wartime memories, especially in the frontier city of Trieste.

These issues, although provocative, only had a marginal impact on the ongoing process of gradual political reconciliation between Belgrade and Rome. Eager to achieve a significant success in foreign policy, Prime Minister Moro desired to accelerate diplomatic contacts throughout 1966. By contrast, Foreign Minister Fanfani suggested that Moro should have greater patience and promote a more gradual process of political normalization. It is noteworthy that, although Fanfani and Moro slightly disagreed on the pace of the Adriatic détente, both personalities agreed to exclude the problem of the territorial border from the planned talks with the President of Yugoslavia's Federal Assembly Edvard Kardelj in $1966 .{ }^{132}$

\footnotetext{
${ }^{128}$ ACS, MI, Gabinetto, Fasc. Correnti, 1964-1966, B. 246, Notizie Jugoslavia, Fasc. 15085/1, Folder on cittadini jugoslavi in Rubric Frontier (R.F), June 8, 1965.

${ }_{129}$ ACS, Carte Moro, Presidenza del Consiglio dei Ministri 1963-1968, Busta 77, Sottofasc. Visita in Jugoslavia 8-12 Nov. 1965, "Note from Yugoslav Government on Vurdelja Dragoliub," Undated.

${ }^{130}$ MAE, "Telegram Koper to Rome," August 26, 1965.

${ }^{131}$ ACS, Carte Moro, Presidenza del Consiglio dei Ministri 1963-1968, Busta 78, Fasc. Visita in Jugoslavia 8-12 Nov. 1965, Telegrammi, Sottofasc.5, "Vidali to Moro," November, 1965.

${ }^{132}$ ACS, PCM, Ufficio Consigliere Diplomatico, Busta 66, Sfasc. 4, “Correspondence Moro-Fanfani,” June, 1966.
} 
In summary, after the Hrescak case, the breach between the central government and the Triestine émigrés and patriotic associational network widened further. Local responses to Prime Minister Moro's visit to Yugoslavia clearly revealed that key segments of the local community proved unprepared to abandon their conservative views and formally recognize Yugoslav sovereignty over the ex-zone $\mathrm{B}$, despite rejecting nationalist extremism. ${ }^{133}$ At the same time, however, diplomatic negotiations were gradually moving forward and, within the context of Adriatic détente, the Italian government was determined to resolve the border dispute. Christian Democrats understood that people in Trieste, mindful of Yugoslav war-time occupation and experiencing increasing impoverishment, firmly opposed any further political, economic, and territorial concession to Tito's regime. Indeed, from a local perspective, the chronic economic crisis of Trieste and its port was a direct consequence of the Italian state's incompetence and the loss of its Istrian region. For its part, the Italian government had already implemented a new economic plan, the intent of which was to revamp the Triestine port and its economy. Its unintended consequences, however, were a weakening of local loyalties to the Italian state and a reawakening of Trieste's independent spirit.

\section{"Ora basta!" (Enough is Enough!): Trieste's Response to the CIPE Plan}

Since the early 1960s, Trieste's shipyard industry had fallen into a state of decay due to an irrational post-war reconstruction policy that had damaged its traditional competitiveness. ${ }^{134}$ Indeed, a comparative analysis of the port traffic showed that a steady revenue increase for the ports of Fiume and Hamburg, which were favorably supported by advantageous tariffs and infrastructure, had relegated Trieste's traffic to the level of $1940 .{ }^{135}$ In line with the European Community's economic provisions for the modernization of national shipyard industries, the central government therefore decided to restructure the productive capacities of the Triestine industry, in particular the

\footnotetext{
${ }^{133}$ ALN, Segreteria Politica, "Muratti to Franzil," May 30, 1966.

${ }^{134}$ Paolo Fragiacomo, L'industria come continuazione della politica: la cantieristica italiana, 1861-2011 (Milano: Franco Angeli, 2012), 178-193.

${ }^{135}$ ACS, Ufficio Consigliere Diplomatico, fasc. 319, Busta 90, Trieste, Porto.
} 
"San Marco" shipyard. During the 1963 parliamentary debate on how to increase the competitiveness of the Italian shipyard industry, the central government claimed its intentions to upgrade San Marco’s facilities. ${ }^{136}$

In 1965, the government publicly announced its plan for the San Marco facilities and, more generally, Trieste's port economy. The plan prospected the end of ship production in San Marco and the conversion of its facilities into a repair dock with the guarantee of reallocating its workers in other regional facilities to avoid any problem of unemployment. The terms of the plan, however, were harshly criticized by the political opposition which claimed that the government strategy for Trieste would lead to the closure of the San Marco shipyard facilities. Trieste's Commissioner Libero Mazza sent a note to Prime Minister Moro explaining that the complexity of the issue surpassed its pure economic dimension. The San Marco shipyard mattered not just for the workers but also for Trieste as a whole and its alleged prospective closure would only detrimentally affect local support for the central government. After years of Allied occupation and invaluable sacrifice in the defense of the border's "Italianità," Mazza argued, "Trieste would perceive Rome's decisions as a clear sign of disinterest toward the city," regardless of governmental claims that it needed to meet European expectations for the modernization of the Italian maritime sector. ${ }^{137}$ This note clearly stressed the inescapable interconnection between the economic and political aftermath of the CIPE plan on the Triestine community, which was eager to receive some proof of national solidarity after years of economic and social decay.

At the time, growing resentment toward the central government for years of inaction and empty patriotic rhetoric was expressed in ordinary conversations and jokes. In asking each other what the government would do at San Marco when it stopped making ships, people answered "they will make a tubular pipe from which politicians will proclaim that Trieste is dear to every Italian

\footnotetext{
${ }^{136}$ UZC, Sezione IV Trieste, Busta 6, "Response to Vidali's parliamentary motion," November 12, 1963.

${ }^{137}$ UZC, Sezione IV Trieste, Busta 12, Vol. I "Mazza to PCM," February 17, 1965,.
} 
heart." ${ }^{, 138}$ Despite its wealthy appearance, Trieste had indeed paid for its geographical isolation and lack of infrastructure. Beginning in 1956, the city's income rate had grown at a pace that was half of the national average.

Not only political opposition but also the Triestine local council, led by a center-left majority, stressed that the chronic crisis of the maritime sector of the shipyard industry needed state intervention to modernize and optimize its uncompetitive facilities and infrastructure. ${ }^{139}$ In his correspondence with Moro, Trieste's mayor Mario Franzil stressed that, due to its geo-political location, the implementation of the CIPE plan threatened to further suffocate rather than save Trieste's port economy. With an aging population, stagnant maritime traffic and comparatively lower incomes, the CIPE plan would have greatly benefited the Yugoslav Adriatic ports and fatally compromised Trieste's competitiveness, according to the mayor. In addition, Franzil emphasized the political backlash that would result from the government's decisions for both Trieste's local economy and politics. In confronting local reactions to the plan, "the local Christian Democrats would have been forced to break party discipline and align with the protests of the local population which would have had unpredictable consequences on the fall elections of 1966."

As outlined above, the national government was well informed about the potential downsides of the CIPE plan. In spite of this, it thought it could rely on the support of segments of the local Christian Democrats who hoped to negotiate with the central government and modify some of its crucial economic provisions. With regard to this issue, local Christian Democrat Sergio Coloni vigorously opposed the criticism coming from the Communist Party which had long advocated an alternative strategy based upon massive state investments and favorable tariffs to restore Trieste's lost competitiveness in the European market. Indeed, in Communist propaganda,

\footnotetext{
${ }^{138}$ Robert C. Doty, "Trieste Bitter on City’s Wane; Fights Loss of a key Shipyard," The New York Times (May 30, 1965).

${ }^{139}$ ACT, Meeting of June 14,1965.

${ }^{140}$ UZC, Sezione IV Trieste, "Franzil to Moro",November 25th, 1965, Busta 12, Vol.I
} 
ending the production of ships in the San Marco facilities represented a "deadly blow" to the Triestine economy. ${ }^{141}$

During a local economic conference that overlapped with the debate over the modernization of San Marco shipyard, the keynote speaker repeatedly stressed the steady regression of Trieste as compared to other Italian cities and the minimal growth of the port's traffic. The main reasons for its decline, he claimed, rested on the unnatural border that separated Trieste from its hinterland and the rising competitiveness of the other Adriatic ports, resulting in the mass emigration of qualified manpower and net redirection of maritime traffic toward ports better connected to East-Central Europe. This negative portrayal overlooked and unfairly minimized the achievements of the local administration since $1954 .{ }^{142}$ In addition, it also ignored the significant political achievements of the post-war governments in fostering political discussion with the Adriatic neighbor and opening the way to new economic opportunities. These new opportunities, however, required a specific intervention to replace and upgrade the outdated infrastructure of its shipyard industry. ${ }^{143}$

From the government's perspective, the CIPE plan responded to these needs. Between 1965 and 1966, the plan redesigned the national shipyard industry and optimized the conversion of the productive facilities of the San Marco shipyard from the production of ships to a repair dock. As a form of compensation for putting an end to the production of ships in San Marco, Trieste was granted the general headquarters of the state controlled company "Italcantieri." Despite the apparent prestige that came with locating the company in Trieste, the CIPE threatened to minimize Trieste within worldwide maritime traffic and, in the eyes of the Triestine population, further increased unemployment. Thus, the CIPE became object of a prolonged political debate in Trieste.

Christian Democratic leader Sergio Coloni, for example, predicted a bright future for the production of diesel engines, significant improvements to the transportation system between Trieste and the new facilities of Monfalcone, the modernization of San Marco, and the invaluable role that

\footnotetext{
${ }^{141}$ AFG, Fondo APC, Serie Regioni e Province (RP), MF0524, Conference on Triestine Economy, January 30-31, 1965.

${ }^{142}$ ACT, Verbali Seduta Ordinaria, March 1, 1966.

${ }^{143}$ UZC, Sezione IV, Busta 52, Folder conferenza economica problemi triestini, "Triestine Municipal Council to Moro," March 24, 1966.
} 
"Italcantieri" could play in revitalizing the local economy and reducing the drain of skilled workers. ${ }^{144}$ In contrast, the National League criticized the outdated use of diesel technology and its problematic absorption of a high number of workers employed in the Triestine maritime sector. As for the Monfalcone facilities, the National League argued that they would transfer prominent economic activities next to the Yugoslav border and further the ongoing depopulation of Trieste and concurrent Balkanization of the Italian Eastern border, which would then serve as a preliminary step to Yugoslav annexation.

In purely economic terms, the executive committee of the National League argued that the San Marco shipyard was ill equipped to face its new proposed task to serve as a repair dock. As a consequence, incoming ships would divert their routes to more prepared Yugoslav ports and the volume of maritime traffic in the Triestine port would decline. This result would jeopardize potential economic benefits coming from the transalpine oil pipe Trieste-Ingolstadt that, beginning in Trieste and running through Italy, Austria, and Germany, could boost the flow of maritime traffic through the Triestine port. The National League argued that the CIPE plan left the unfavorable trade tariffs for the port unresolved, would lead to the unemployment of 1,500 qualified Italian workers, and would increase the immigration of Slovene workers in Monfalcone. ${ }^{145}$

Similarly, the President of an Istrian group of ex-zone B sent a letter to the National League in which he argued that the weakness of the local Christian Democrats and the government's economic decisions had greatly facilitated the "Slavization" of Trieste. According the letter, the leadership of the local secretary of the Christian Democrats, Guido Botteri, a figure strongly connected to the politicians in Rome, had also facilitated this process and revealed the increasing marginalization of prominent Triestines and Istrians inside the city's political establishment. As a result, he said, local émigrés feared that the central government was gradually withdrawing from its traditional defense of Italian claim over the ex-zone B. ${ }^{146}$

\footnotetext{
${ }^{144}$ DT, Fondo Coloni, Busta 3.

${ }^{145}$ ALN, Segreteria Riservata, “Le mirabolanti promesse del CIPE e le bugie democristiane ai danni di Trieste,” 1966.

${ }^{146}$ ALN, Segreteria Riservata, Letter from Istrian Community, Fameia Gallesanega, October 26, 1966.
} 
In voicing their dissent against the CIPE plan, both the National League and the émigrés underscored the idea of "Slavization" as a consequence of Trieste's economic weakness and decline. Not only these associations but also large segments of the local population viewed the government's plan as a deadly threat to both the port economy and Italian identity of Trieste. Therefore, popular anger exponentially rose, targeting the local Christian Democrats who were accused of being submissive to Rome and ignoring Trieste's needs. However, local Christian Democratic Party representatives like Franzil repeatedly stressed the socio-economic repercussions of the CIPE plan, but their concerns were downplayed by the central government.

The national Christian Democratic leadership, indeed, had shown a lack of political foresight toward a city that during the post-war years had experienced continuous economic, political, and cultural marginalization from the rest of the nation. Over time, this process transformed the Triestine Christian Democrats into the main targets of both leftist and rightist propaganda. Socialist Bruno Pincherle, for example, accused the local Christina Democrats of complying with the central government which favored local private interests at expense of the local city's shipyard industry. He also added that all previous state commitments such as a new highway, railway, airport and port docking facilities, which could have removed Trieste from its geographical and economic isolation, remained on paper. After years of failing policies, Pincherle concluded, "the city's council should send a clear signal of discontent to the Roman authorities by opposing the closure of San Marco and, if necessary, taking over the industry." "147

Although the CIPE plan intended to convert the San Marco's facilities to a repair dock, the left and right-win political opposition publicly claimed its forthcoming closure. Rightist politicians such as the Italian monarchist Alfredo Covelli also harshly criticized the central government for the potential aftermath of the CIPE plan which would further Trieste's continuous economic marginalization. Covelli stated that the Julian city, the traditional core of Adriatic trade and patriotism, had slowly declined in the midst of the apathy of the national community and the

\footnotetext{
${ }^{147}$ IRSML, Fondo Burno Pincherle, Busta 11, Fasc. Cantieri, "Mozione sul San Marco," June 23, 1966.
} 
cynicism of its governing elites, despite the sacrifices that its population had consciously faced to reassert its "Italianità." Covelli, recalling Trieste’s past strivings for autonomy and independence, argued that "Trieste could demand to be free rather than beg for help."148

In a letter to Senator Giusto Tolloy, Prime Minister Moro proved aware of the growing popular animosity toward the central government that boiled in Trieste. ${ }^{149}$ These impressions were further confirmed by Commissioner Libero Mazza, who proposed to raise state financial support for Trieste to positively shape local public opinion and make the terms of the CIPE plan more acceptable. In particular, Mazza highlighted the renewed activism of the pro-Independence Front which best exemplified the discontent and disillusionment within the local community. However, he also labeled the phenomenon as socially marginal and politically insignificant. ${ }^{150}$

In contrast, Guido Botteri understood the possible negative effects of a rising local proindependence and nationalist opposition. In stressing the discrepancy between Rome's patriotic rhetoric and lack of attention to the real problems of the city, Botteri warned Moro once more of a possible political backlash in the November elections. ${ }^{151}$ Consequentially, a faction of the Triestine Christian Democrats decided to embrace the defense of Trieste's port economic interests and, by refusing to abide by the directives of the central government, ultimately broke ranks with the party's traditional discipline.

Meantime, neo-fascist propaganda claimed that the "closure" of the San Marco shipyard was the natural consequence of the foolish domestic and foreign policy of center-left coalition government. ${ }^{152}$ The right-wing press emphasized that Trieste, which had been already deprived of its natural hinterland after nine years of foreign occupation, was now on the verge of economic collapse. Indeed, the city's economy, untouched by the Italian economic miracle, drained by the competition of the ports of Fiume and Capodistria, and damaged by the absence of adequate

\footnotetext{
${ }^{148}$ AC, Fondo Covelli, Discorsi e Scritti, Busta 5, fasc. 109, 1966.

${ }^{149}$ UZC, "Moro to Tolloy," Sezione IV, Trieste, Busta 12, Vol. II, June 11, 1966.

${ }^{150}$ UZC, "Mazza to Moro," Sezione IV, Trieste, Busta 12, Vol. II, July 8, 1966.

${ }^{151}$ UZC, "Botteri to Moro," Sezione IV, Trieste, Busta 12, Vol. II, July 21, 1966.

${ }^{152}$ ACS, MI, Gabinetto, fasc. 12010/85, Busta 79, Attività dei partiti, 1964-1966.
} 
infrastructure, had been long forgotten by the political establishment in Rome. Above all, neofascists argued that the government's new plan only supported Genoa's maritime interests and would spark a process of Balkanization that would transform the eastern border into an open gate for Slavism rather than an opulent and prosperous outpost against Yugoslav Communism. ${ }^{153}$

Furthermore, the central government also had to respond to communist propaganda which called for workers' mass strikes in Trieste during both the summer and the fall of $1966 .{ }^{154}$ Luigi Longo, the secretary of the Italian Communist Party, assured the local trade unions that the workers' protests against the CIPE plan would have total support from the party. Moreover, Longo stressed the communists' commitment to the creation of a free trade area and a regional port authority in order to save Trieste's economy from policies that would only accelerate its decline and spur mass emigration. $^{155}$

Thus, the CIPE plan increasingly strained political relations between Trieste and Moro’s center-left coalition government. In a letter to Socialist leader Pietro Nenni, the ex-director of Triestine progressive newspaper Il Piccolo, Rino Alessi, articulated the feelings of discontent and isolation that pervaded Trieste and highlighted their main socio-political implications. Due to Trieste's proximity to Yugoslav Communism, Alessi argued that the escalation of the local protests could impair the progress of the Adriatic friendship. Indeed, Alessi added, "only a re-born Trieste, free of the seeds of past nationalisms" could be the fulcrum of a new Italian policy toward Yugoslavia. ${ }^{156}$ In a context of rising unrest in Eastern Europe and economic growth of the Istrian region, a prosperous Trieste could indeed function as a bridge between a new socialist Europe and Italy, Alessi asserted. Its economic crisis, however, had weakened feelings of confidence and trust toward the new progressive polices of the center-left coalition and needed to be promptly reversed to advance Italian interests in the Adriatic region. In his analysis, Alessi effectively summarized the

\footnotetext{
${ }^{153}$ Amedeo Principi, “Trieste come un rimpianto,” Il Borghese (September 1, 1966).

${ }^{154}$ An interesting video of the strike is available at Archivi AAMOD, Rome (Italy), Sciopero Generale a Trieste, July 7 , 1966.

${ }^{155}$ AFG, Fondo Apc, RP, MF0533, p.0216, "Longo to Venezian,” September 6, 1966.

${ }^{156}$ ACS, Carte Nenni, Busta 17, Fasc. Alessi Rino, "Letter from Alessi to Nenni," September 23, 1966.
} 
political costs of an economic plan that, along with the bitter disapproval of local politicians, boosted hostility toward the central government among the local population, as proven by mass protests and the distribution of a petition against the prospective "closure" of San Marco that collected 80,000 signatures. ${ }^{157}$

In a desperate attempt to minimize local tension and political antagonism, newspapers such as the Christian Democrat Il Popolo depicted the central government's decision to locate the new "Italcantieri" in Trieste rather than in Genoa as a sign of its intentions to make the Triestine port the cornerstone of a five-year plan to re-launch maritime traffic in the Adriatic. ${ }^{158}$ The local newspaper Il Piccolo also echoed this argument by praising the government's decision as an "act of justice for the Julian shipyard." ${ }^{159}$ Both the right and left-wing press, for its part, negatively portrayed the government's initiative. The right-wing newspaper Il Secolo d'Italia claimed that, while Genoa benefited from massive investments and financial support that made it the Italian maritime capital, Trieste continued to languish. ${ }^{160}$ Likewise, the national communist newspaper L'Unità argued that the downsizing of the local shipyard industry favored foreign private interests, minimized state commitment to Trieste's maritime sector and ultimately undermined the interests of the Triestine port workers. ${ }^{161}$ The journal, which had traditionally supported the internationalization of the Triestine port, reiterated an economic strategy that advocated Trieste's role as the engine of regional economic integration with the eastern and southern part of the Adriatic. ${ }^{162}$

The political debate within the Triestine public sphere showed that supporters and detractors of the government's economic strategy for Trieste used the CIPE plan to respectively point to state commitment or state disengagement from the city's port economy. The public campaign of both right and left-wing political parties ultimately overshadowed the state's compensation for the

\footnotetext{
${ }^{157}$ Manlio Cecovini, Del patriottismo di Trieste. Discorso di un triestino agli italiani nel cinquantenario della redenzione. (Milano: all'Insegna del Pesce d'oro, 1968), 130-132.

158،"Lo sciopero a Genova per i cantieri," Il Popolo (October 6, 1966).

159،"Trieste designata sede centrale dell'industria cantieristica di stato," Il Piccolo (October 6, 1966).

160 "Il CIPE ha deciso: Trieste sede dell'Italcantieri e provvedimenti compensativi per Genova," Il Secolo d'Italia (October 8, 1966).

161“"Balzo in avanti del capitale americano in Italia," L'Unità (June 26, 1966).

${ }^{162}$ Marco Marchetti, "Non si deve decidere sui cantieri prima del dibattito sul piano," L'Unità (October 4, 1966).
} 
conversion of the San Marco's facilities and persuaded the Triestine workers to mobilize against the imminent "closure" of the San Marco shipyard. Thus, in early October 1966, after months of political polemics and accusations against the central government, Trieste exploded in social and political turmoil. Mass demonstrations and worker strikes, which also saw the participation of rightwing groups on the side of the port's workers, met with the strong repressive actions of the local police. ${ }^{163}$ The communist press described the local incidents as the logical consequence of years of chronic depression and praised the unitary and heroic action of the workers of both Genoa and Trieste. ${ }^{164}$

The violent demonstration of October 8 represented the peak of Trieste's protest against the CIPE plan and was subsequently portrayed as the "dark days of the Triestine October."165 Protesters threw bricks as they headed towards the Christian Democrat headquarters and the main office of the newspaper Il Piccolo, which they perceived as supportive of the government. Workers created barriers and confronted local authorities in a prolonged riot which, according to local Christian democrat leader Sergio Coloni, was premeditated and incited by communist agitators, also defined as "sangiacomini." 166 The vandalism and violent nature of the protests resulted in 450 wounded and 50 arrests; among them, 22 had previous criminal records. External observers also depicted these urban riots as the outcome of the actions of a thousand angry workers who violently responded to the government's plan to convert the San Marco shipyard into repair docks. ${ }^{167}$

Instead, in its coverage of the riots, L'Unità stressed the repressive actions of the local police which it connected to the authoritarian nature of the Italian state. The newspaper depicted the urban riots and the indiscriminate police attacks against 7000 workers and unarmed bystanders in great detail. Such widespread violence, it argued, left the city in a state of unbelievable chaos until

\footnotetext{
${ }^{163}$ Vezzà and Comelli, 119.

164،"Trieste è scesa in piazza per difendere il lavoro," L'Unità (October 5, 1966).

${ }^{165}$ Audio-visual material, Archivi AAMOD, Rome (Italy), Trieste, October 8, 1966.

166“"Giornata di gravi disordini a Trieste," Il Piccolo (October 9, 1966).

167“"Workers in Trieste Clash with Police," The New York Time (October 9, 1966).
} 
late evening. ${ }^{168}$ This account, which highlighted the brutality of the local police, crystallized into the local communist narrative of the events which portrayed the days of October as one of the most important moments in the history of the city. These "glorious" days were later used in communist propaganda to enhance a local sense of victimization and fuel workers' animosity toward the government. ${ }^{169}$

Conversely, the right-wing newspaper Il Secolo d'Italia depicted the riots and the police repression against the San Marco's workers as the outcome of communist activities. ${ }^{170}$ The newspaper harshly criticized the workers and depicted them as communist believers who transformed "a justified reaction against unfavorable economic decisions into a political event with a strong anti-national accent." ${ }^{171}$ Christian democratic newspapers such as Il Popolo also emphasized the responsibility of the Communist Party which they believed had fomented urban fighting and had spread unfounded rumors about the imminent closure of the San Marco facilities. The communists, Il Popolo argued, had caused local workers to attack the Triestine Christian Democrats and claimed that the urban riots were part of a broader communist plan to gain support before the upcoming elections. ${ }^{172}$

During the parliamentary debate of October 10, 1966, members of the national government reiterated their belief in the planned rather than spontaneous nature of the Triestine accidents. They argued that, on the night before the incidents, the Communist Party had not only fostered local tensions against the Triestine authorities but had also profited from the support of agitators who had infiltrated across the Adriatic border and were very well-known to the Triestine communist movement. ${ }^{173}$ To further prove this point, Christian Democratic representatives also reported that

\footnotetext{
168،"Possente protesta operaia a Trieste, il governo scatena la polizia," L'Unità (October 9, 1966).

169“"Il piano CIPE un anno dopo," Il Lavoratore (October 1, 1967).

170 "Violenti scontri nelle vie di Trieste: barricate, sassaiole e vandalismi," Il Secolo d'Italia (October 8, 1966).

171،"Tumulti a Trieste minacce da Genova," Il Secolo d'Italia (October 9, 1966) .

172،"Gravi incidenti a Trieste fomentati dai comunisti," Il Popolo (October 9, 1966).

${ }^{173}$ Camera dei Deputati, Rome (Italy), Atti Parlamentari, October 10, 1966.
} 
the local Communists used Radio Capodistria to spread false news about the death of two workers. $^{174}$

A report from Commissioner Libero Mazza effectively confirmed the responsibility of the workers, infiltrated agitators, and the Independence Front especially. On October 8, Mazza argued, members of the Independence Front provoked local disorder with the specific aim to provide the mass demonstrations with a strong anti-national tone. Indeed, in the aftermath of the incidents the Independence Front partially succeeded in attracting support among workers and leftist extremists who favorably looked at the idea of a free and independent territory of Trieste not for "sentimental, but rather utilitarian goals." 175

The CIPE plan and its socio-political aftermath effectively undermined popular confidence in the government's ability to restore Trieste's port economy. In an interesting letter to Trieste's Christian Democratic secretary Sergio Coloni, local economist Maurizio Fanni argued that the CIPE plan and the prospective realization of the Trieste-Ingolstadt oil pipe were necessary yet insufficient measures to restore Trieste's traditional trade with its Danubian hinterland. The detail of utmost importance, Fanni argued, was the intensification of commercial agreements with the Eastern European socialist economies and "the transformation of Trieste into the eastern library of the Western world. "176 In such a view, the city would work as a sort of research center for the collection and elaboration of marketing information in order to better calibrate national economic strategies toward the countries of the Soviet bloc.

Thus, from this perspective, by employing political and economic pragmatism, the government would support Trieste's economic growth, the strengthening of local loyalty toward the Italian state, and the process of political relaxation with the Yugoslav neighbor. ${ }^{177}$ At the time, these goals occupied a prominent role in the government's agenda and best fit the new strategy for Trieste. In a note to Moro, members of the Ministry of Finance reiterated these views. They noted

\footnotetext{
${ }^{174}$ UZC, Sezione IV, Busta 32, Folder Radio Capodistria, 1966.

${ }^{175}$ UZC, Sezione IV Trieste, Busta 12, Vol. II, Confidential "Prefect to Ministry Council," October 17, 1966.

${ }^{176}$ DT, Fondo Coloni, B. 3, Folder Democrazia Cristiana, "Note from Maurizio Fanni," 1967.

${ }^{177}$ Cecovini (1968), 139.
} 
that the prolonged economic crisis as well as the political debate surrounding the CIPE plan had produced phenomena of political violence and had threatened the cohesion of the Christian Democrats; however, they added, public disorder also strengthened the attractiveness of the political experiment of the center- left as a barrier to political extremism. ${ }^{178}$

The days of violence had indeed shocked the Triestine population whose majority still traditionally voted for the Christian Democrats and deeply distrusted the communist movement. Despite this, Coloni argued, the violent protests of early October had also sent a clear message to Roman politicians: "Trieste needed to be given a specific role within the general interest of the nation. $" 179$ This issue took on specific importance in the context of the upcoming municipal elections and became a test of stability for the city, which was still in shock by the urban violence and was pervaded by the anti-governmental propaganda of the neo-fascist, communist, and independence movements.

In anticipating the local administrative elections, the central government claimed that the CIPE plan would lead to massive investments during a transition period of four to five years and ultimately save the local shipyard industry. ${ }^{180}$ These claims, however, only partially succeeded to persuade the local population which looked with increasing confidence toward the Independence Movement. After 1954, this movement had often highlighted the government's violations to the terms of the London Memorandum and repeatedly stressed its failure to rescue Trieste's local economy; however, popular support for the movement had remained minimal. ${ }^{181}$ Its popularity suddenly surged in 1966 in the aftermath of the CIPE. ${ }^{182}$ Perhaps predicting the electoral success of this movement, the Communist Party also sought an electoral alliance with the local independence

\footnotetext{
${ }^{178}$ UZC, Note from Members of the Chamber of Deputy, Sezione IV Trieste, Busta 48, October 9-10, 1966.

${ }^{179}$ DT, Fondo Sergio Coloni, Busta 3.

${ }^{180}$ DT, Fondo Coloni, B. 3, Folder Democrazia Cristiana, 1967.

${ }^{181}$ ACS, MI, Schedario Partiti Politici 1944-1966, B.106, fasc.,312/P, Trieste Movimento Interdipendentista, "Mazza to Gabinetto," July 23, 1966.

${ }^{182}$ See Stelio Spadaro, "Due momenti salienti dell' indipendentismo": il Boom del 1952 e il Piano Cipe del 1966, in Dalla liberazione agli anni '80, Trieste come problema nazionale, edited Armando Cipriani (Roma: Salemi editore, 1984), 119-147.
} 
group, the "Unione Triestina" (Triestine Union). ${ }^{183}$ Its refusal to enter a political alliance, however, further isolated the Communist Party. ${ }^{184}$

In the local administrative elections of November 1966, the Independence Front gained significant electoral support that did not go unnoticed by the local, national, and international press, including the New York Times which read the electoral result as a "rebuff to Rome."185 Even though the discrepancy in voting support for the independence front $(4.4 \%)$ as compared to the governing Christian Democrats (31.9\%) was evident, its rise and the Christian Democrats' decline in popular votes demonstrated the mounting disillusionment within the city. Above all, the ability of the independence movement to attract local support at this specific and critical moment highlighted the lasting tension between Trieste's autonomous economic ambitions and its identification with the Italian state. $^{186}$

According to local intellectuals such as Carl Schiffrer, the re-emerged Independence Movement, while nostalgically appealing to past and consolidated understandings of the special role played by the port city inside the Adriatic space, ultimately aimed to undermine the progressive measures taken by the central government to promote its European integration. Consequentially, Schiffrer argued, the problematic reality of Trieste was that it was a city in which the "municipal dimension was surpassed." ${ }^{187}$ Local resistance to the CIPE plan definitively exposed this tension between nostalgia for Trieste's past prosperity and the need to modernize its port economy, including the conversion of the San Marco facilities.

Although the CIPE plan had promised to break the vicious economic spiral that had relegated the city to a condition of "dependence" and re-integrate Trieste into the global economy, pro-independence political movements such as "Trieste ai Triestini" (Trieste to the Triestines) used Trieste's response to it to stress the lack of credibility of the national political class, its misleading

\footnotetext{
${ }^{183}$ ACS, MI, Partiti Politici, Schedario 1944-1966, Trieste Movimento Interdipendentista, fasc. 312/P, Busta 106.

${ }^{184}$ AFG, Fondo Apc, RP, MF0533, p.0228, "Lusvardi al Comitato Centrale,” December 12, 1966.

185“"Trieste Vote Seen As Rebuff to Rome", The New York Times (November 30, 1966).

${ }^{186}$ ACS, MI, Gabinetto, Fasc. Correnti, 1967-1970, B.23, Fasc.312P, "Memorandum from Triestine police," October, 1967.

${ }^{187}$ Carlo Schiffrer, “La dimensione sorpassata della città municipale,” Trieste (1966).
} 
economic strategy, and unnatural separation of Trieste from its Istrian hinterland in the slogan, "We are not eternal watermelons!"188 The watermelon and the halberd represented the old Triestine nobility and symbolized Trieste's autonomous ambitions which could now take a more aggressive path.

Thus, the government in Rome, while rhetorically promising to restore Trieste's port economy, also mobilized the local associations that had traditionally supported its post-1963 policy toward the border. Through the border office, the central authorities financially supported the activities of pro-governmental Italian cultural, recreational and Catholic associations as well as noncommunist trade unions. In addition, it financially sustained local newspapers and magazines such as La Voce Giuliana or Trieste which publicly supported the experiment of the center-left and its positive effects on Trieste's port economy. ${ }^{189}$ Furthermore, the Office of Border Zones (UZC) also reinstated former financial support for the Istrian C.L.N. which was led by an executive committee of Republicans, Christian Democrats, and Socialist Democrats. Governmental contributions to this émigré association were made on a regular basis and were also accompanied by extraordinary funding on special occasions such as the twentieth anniversary celebration of its foundation in 1965 . From a Christian Democratic perspective, the Istrian C.L.N., later renamed "Associazione delle Comunità Istriane" (Association of the Istrian Communities) in 1967, had played a crucial role in assisting the émigrés of the ex-zone B and the Italian community still living in the territory under Yugoslav administration. In particular, this association and its democratic propaganda had worked as a shield against the infiltration of right extremists within the émigré community in Trieste. ${ }^{190}$ At the same time, the Italian government drastically reduced governmental contributions to the national émigré association, the ANVGD. In firmly opposing Yugoslav sovereignty over the ex-

\footnotetext{
${ }^{188}$ ACS, MI, Dipartimento della Pubblica Sicurezza, Cat. G, Associazioni 1944-1986, B.238, Miscellaneous, November 9, 1967.

${ }^{189}$ UZC, Sezione VI, Busta 6, Folder spese per zone di confine, 1966-1967.

${ }^{190}$ UZC, Sezione V, Busta 9, Vol.I, Folder Comitato di Liberazione Istria, "Correspondence and Contributions 19651966".
} 
zone $\mathrm{B}$, the views of this association clashed with the new imperatives of the Christian Democratic foreign policy toward Tito's regime, among them the formal settlement of the Istrian problem. ${ }^{191}$

This strategy effectively aimed to draw local public opinion away from former intransigent positions, especially in relation to the status of the ex-zone B, an issue that still impeded the full normalization of political relations with the Yugoslav neighbor. In addition, this issue became object of political manipulation by local and national neo-irredentist associations whose extremist views found in the Italian neo-fascist party their main political referent. ${ }^{192}$ The National Italian Irredentist Association (ANII) was certainly representative of this broader phenomenon. In 1967, during the twentieth anniversary of the signing of the Paris Peace Treaty, the ANII organized a demonstration against the ignominy of the "dictated peace" in Rome. In his speech to the demonstrators, Bruno Coceani argued that while the fascist regime extended the nation's natural borders from "Brennero to Nevoso," the new Republic passively witnessed the territorial mutilation of the Julian region. ${ }^{193}$ In its correspondence with Prime Minister Moro, the ANII went so far as to claim that the government's policy would ultimately lead to the "Slavization" of Trieste. ${ }^{194}$ These arguments were saturated with radical nationalism and were rejected by other parts of the neoirredentist movement, such as the National League war veteran and patriotic formations that politically identified with the Christian Democrats. ${ }^{195}$

Although these groups condemned the strong neo-fascism that pervaded associations such as the National Italian Irredentist Association, they also opposed a definitive renunciation to the exzone B and supported the status quo that, established by the London Memorandum, best served the political, cultural, and economic rights of both the émigrés and the Italian minority of the ex-zone B. The Italian government, partially aligning with the objectives of these associations, still firmly

\footnotetext{
${ }^{191}$ ACS, PCM, Ufficio Consigliere Diplomatico, Busta 49, AssociazioneVenezia Giulia e Dalmazia, "Fanfani to Barbi," October 13, 1966.

${ }^{192}$ ACS, MI, Gabinetto, Fasc, Corrrenti, B.102, Fasc.12010/85, Trieste e Provincia Attivita' dei Partiti, "Prefect of Trieste to Gabinetto," July 19, 1967.

${ }^{193}$ ACS, PCM, Ufficio Consigleire Diplomatico, Busta 49, Associazione Nazioanle Italia Irredenta 1967, "Pamphlet on Bruno Coceani’s Speech,” February 26, 1967.

${ }^{194}$ ACS, PCM, Ufficio Consigleire Diplomatico, Busta 49, Associazione Nazionale Italia Irredenta, "Correspondence ANII-Moro," December 7-29, 1967.

${ }^{195}$ AST, Fondo Coceani, R/9, 565, March 17, 1967.
} 
monitored the situation of the Italians living in the ex-zone B and exercised political pressure on the Yugoslav government to improve their conditions. ${ }^{196}$ For example, in 1967, Minister of Foreign Affairs Fanfani agreed with Moro to interrupt commercial negotiations in order to safeguard the citizenship rights of the Italian residents of the ex-zone B who had experienced further restrictions.

Despite this, in a secret report from Belgrade, the Italian Ambassador Roberto Ducci informed the Italian political adviser Gianfranco Pompei that the government's show of strength toward the Yugoslav neighbor on the issue of the documents had been received only with moderate satisfaction among the Italian community living in the ex-zone B. The report stated that while Triestine entrepreneurs proved more interested in protecting good economic relations with Yugoslavia, Italians in the ex-zone B would have hardly protested against provisions that violated their rights to Italian citizenship; rather, they preferred to preserve good socio-political relations with the local Yugoslav authorities. Indeed, the report continued, Triestine entrepreneurs increasingly favored a definitive agreement on the eastern frontier, a decision that "would have caused tension some years ago, would foment popular protests now but will be accepted without excessive problems in a few years."197

This report aptly summarized mainstream thinking within the entrepreneurial segments of the Triestine community that mirrored the views of the Christian Democratic governing elites. It suggested that segments of the Italian community who were living along the Adriatic border gradually understood the limits of an outdated irredentist policy toward the ex-zone B which was almost depopulated of its Italian minority. It therefore overwhelmingly approved the state's policies that, while preserving the Italian cultural and linguistic identity of Trieste and its Istrian region, sought to boost local economic prosperity while largely abandoning ambitions of territorial reincorporation.

This strategy also explains why Ambassador Ducci proved critical of the Italian government's decision to interrupt commercial negotiations with Yugoslavia in 1967. This move,

\footnotetext{
${ }^{196}$ ASR, Sezione IV, Fanfani Diari, January 19, 1967.

${ }^{197}$ ACS, PCM, Ufficio Consigliere Diplomatico, Busta 66, Sfasc.5, "Note to Pompei,” March 8, 1967.
} 
along with the problematic issue of the Adriatic platform for fishing rights, was perceived by both the Yugoslav government and public opinion as a clear expression of irredentist feelings. ${ }^{198}$ Fanfani therefore suggested to Moro to cautiously re-open negotiations with the Yugoslav government and, when dealing with Italian sovereignty over the ex-zone B, "to conceal the fact that the Italian government would be ready for a future formal recognition of Yugoslav sovereignty without appropriate compensation." ${ }^{199}$ As this letter demonstrates, figures like Fanfani, who was later depicted as a strong defender of the border's "Italianità," also understood the problematic defense of formal Italian rights over the ex-zone B and agreed to seek maximum economic compensations for a territorial loss that was inevitable and could only be postponed.

Instead, the views and attitudes of the majority of the local neo-irredentist formations did not significantly change. Indeed, the commemorations as well as the promotion of the cultural legacy of leading irredentist figures remained central to the activities of multiple neo-irredentist formations. ${ }^{200}$ Groups of émigrés inside the National Italian Irredentist Association also proposed the creation of a new Parliament of Fiume, Istria, and Dalmatia to strengthen émigrés' political support for rightist political formations. In particular, they planned to better coordinate the activity of different associations, national parties and foreign governments that might be interested in sabotaging Italian and Yugoslav relations. This plan, however, did not meet significant support among associations such as the National League and the ANVGD which, once more, distanced themselves from the radical nationalist initiatives of the National Italian Irredentist association. As a result, the strength of the neo-irredentist associational network further faded. ${ }^{201}$

As discussed, amidst rising political disillusionment and chronicle economic stagnation, the CIPE plan was exploited by national and local political formations to weaken popular support for

\footnotetext{
${ }^{198}$ ACS, PCM, Ufficio Consigliere Diplomatico, Busta 66, Sfasc.5, “Ducci to Director Economic Affairs," October 3 , 1967.

${ }^{199}$ ACS, PCM, Ufficio Consigliere Diplomatico, Busta 66, Sfasc.5, "Fanfani to Moro,” October 31, 1967.

${ }^{200}$ ACS, MI, Divisione Affari Riservati, 1957-1960, B. 222, Folder Associazione Amici del Vittoriale, "Confidential Note on Legione del Vittoriale," September 8, 1967.

${ }^{201}$ US, Fondo Luigi Papo, Busta 3, fasc.17, "Relazione Riservata sugli Esuli Giuliano-Dalmati," 1967.
} 
the Christian Democratic coalition government. ${ }^{202}$ In Trieste, mass protests against the CIPE plan also facilitated the resurgence of popular pro-independence sentiments and resulted in a vortex of urban violence. Not only had the protest against the CIPE plan mobilized the port workers but also other key elements of the Triestine population who nostalgically looked at a past and obsolete industrial model. ${ }^{203}$ Local demonstrations underscored the classic populist themes of an inefficient, degenerate and corrupted democracy along with local accusations to have been "sold out" by Rome. $^{204}$

As former Mayor Bartoli argued, the city's prolonged economic stagnation decisively weakened Trieste's traditional patriotism and, I suggest, local loyalty toward the Italian state. ${ }^{205}$ In response, the Christian Democrats further supported associations and political movements that proved sympathetic to center-left coalition government while also opposing moderate and extremist neo-irredentist formations that demanded the reassertion of Italian territorial rights over the ex-zone B. At the same time, however, segments of the Triestine population were increasingly open to the renunciation of the ex-zone B if accompanied by significant economic benefits. Thus, Rome firmly pursued the formal settlement of the eastern border in the late 1960s and early 1970s.

\section{3-1968: Challenging the Politics of Identity}

This chapter has emphasized that Italy's defense of the territorial sovereignty over the exzone B was greatly affected by the political experiment of the Center-Left, and its abandonment became a mere matter of time and political opportunity. In this context, the Christian Democrats embraced the idea of a global negotiation in exchange for the definitive renunciation of the ex-zone

\footnotetext{
${ }^{202}$ Interestingly enough, the Julian independent movement was not unique in its gender. Other pro-independence groups emerged in South Tyrol and Udine. Even though their views and goals differed, they agreed to create an independecet autonomous union whose under the leadership of the Triestine front for the independence of the FTT. This organization envisioned a federal model of government with broad administrative autonomy for each region and the minimization of state powers, a program that somehow anticipated the 1980s inception of strong regional political formations, for example the Northern League. ACS, MI, Dipartimento della Pubblica Sicurezza, Cat.G, Associazioni, 1944-1986, B.342, Folder Movimenti Autonomisti Italiani, "Statute of UAI," September 14, 1968.

${ }^{203}$ Enzo Bettizza, "Progressisti all'est conservatori a Trieste," Domenica del Corriere (October 23, 1966).

${ }^{204}$ Yves Meny, Populismo e democrazia (Bologna: Il Mulino, 2004), 2.

${ }^{205}$ AST, Fondo Bartoli, Busta 47.
} 
B. This new approach promised to connect Tito's Yugoslavia to the Western world and, especially, restore Trieste's port's economy. Thus, it would directly strengthen the state's image on the border and, indirectly, Trieste's identification with the Italian state.

The Hrescak case, however, exposed the problematic nature of the new Christian Democrats' political project for Trieste. ${ }^{206}$ The controversy produced a sudden explosion of Italian nationalism in the city which revealed lingering political animosity, fear and distrust toward the Slovene minority. The heated local political debate was accompanied by the re-emergence of the confrontation between the forces perceived as pro or anti-Italian and marked a watershed for Trieste: a progressive path toward democracy or regressive turn to the old nationalist ground. In this fashion, the success of the "Morotei" in Triestine politics proved the strength and gradual affirmation of local views which underscored the idea of an open border and the use of political dialogue over violence. $^{207}$

At the same time, however, the protest against the CIPE plan vividly demonstrated the effect of years of local resentment toward Rome. Indeed, after 1954, the port's uninterrupted economic crisis had over time exacerbated political tensions between the disillusioned local population and the national government. The government's inability to extend the "Italian economic miracle" to the city and surpass Yugoslav economic competition transformed its past promises of economic prosperity into "empty words." The central government, eager to cope with the stagnant status of the local economy, firmly pursued a policy of economic modernization that attempted to compensate for the loss of the Triestine economic hinterland, the ex-zone B. The CIPE plan however, fell victim to widespread political manipulation from opposing parties whose propaganda escalated local tensions and contributed to a major outbreak of urban violence in October 1966.

People in Trieste, therefore, increasingly perceived the Italian state as a motherland indifferent to their needs and showed their dissent toward the central authorities by politically

\footnotetext{
${ }^{206}$ Roberto Spazzali, Trieste di fine secolo (1955-2004). Per una storia politica del secondo novecento. (Trieste: Edizioni Italo Svevo, 2006), 54.

${ }^{207}$ Valdevit (2004), 107.
} 
supporting the Independence Movement. The reemergence of pro-independence political attitudes among segments of the Triestine community also demonstrated the resilience of Trieste's past municipal traditions and administrative autonomy. ${ }^{208}$ In the words of scholar Liliana Lanzardo, over time Trieste had become "a small city whose past outweighed its size."209 Thus, local nostalgia for the city's prosperous past and its broad home rule strengthened the cosmopolitan rather than national identity of Trieste, ultimately weakening loyalty toward the Italian state. This perspective, however, remained that of a small though growing minority that opposed former irredentist views of Trieste's identity. ${ }^{210}$

Both the Hrescack case and the CIPE plan ultimately deepened the breach between the conservative thinking of the neo-irredentist associations, the aspiration of a part of the local population for considerable autonomy, and the progressive views of the Christian Democrats and their allies in the center-left coalition. Over time, the government's attempts to reverse Trieste's steady economic decline and uphold the fiction of Italian sovereignty over the ex-zone B had indeed adversely affected its local credibility and fostered a sense of apathy and indifference. By 1967, however, the renunciation of sovereign rights to the ex-zone B in exchange for significant economic benefits had already won the support of the majority of the governing elites and appeared a feasible solution also for the Triestine entrepreneurial elites; however, amid the hostility of the neoirredentist network, it still needed an external pretext to minimize its predictable political cost. As I explore in the next chapter, the Prague Spring worked as an ideal catalyst to consolidate the Adriatic friendship and resolutely pursue a formal settlement of the border dispute.

\footnotetext{
${ }^{208}$ See Alvise Savorgnan, La verità su Trieste: una cronistoria, una denuncia, una proposta (Trieste: Lint, 1980).

${ }^{209}$ Liliana Lanzardo, Grandi motori: da Torino a Trieste: culture industriali a confronto, 1966-1999 (Milano: Franco Angeli, 2000), 18.

${ }^{210}$ Pocecco, ed.Cocco, 133.
} 


\section{Chapter 5}

\section{The Final Farewell to Zone B: the Age of Détente and the Path to Osimo}

In 1853, U.S. President Abraham Lincoln wrote to Italian patriot Macedonio Melloni stating, "The Italian nation must be unified from Venice to Dalmatia and ... any further territorial depredation would be a matricide."1 More than a century later, in 1969, the National Italian Irredentist Association sent an excerpt of this letter to Richard Nixon with hope that the American President would challenge both the process of Adriatic detent and Yugoslav rule of the Istrian region during his visit to Italy. Despite their attempts to persuade Nixon, the territorial reincorporation of the ex-zone B within Italy's national borders had not been a political option for the US administration since 1948. Likewise, the Italian government understood that no change to the territorial status of the ex-zone B in Italy's favor would be made after 1954 and that it could only indefinitely postpone the formal resolution of the border dispute.

After 1954, however, the government's failure to restore Trieste's economy and stop Yugoslav discrimination against the Italian minority of the ex-zone B had increasingly fueled local socio-political animosity toward the Italian state. ${ }^{2}$ During the 1960 s especially, both the Adriatic détente and the experiment of the Center-Left were locally perceived as mounting threats to the restoration of Italian sovereignty over the Istrian region and, therefore, were firmly opposed by a variety of neo-irredentist associations. Thus, the progressive fringes of the Christian Democratic Party avoided any definitive recognition of Yugoslav sovereignty of the ex-zone B until the late 1960s.

However, the 1968 Warsaw Pact's repression of the Prague Spring persuaded the Italian establishment to formally end the border dispute over the ex-zone B. Diplomatic talks began during the official visit to Italy of representatives of the Yugoslav Federation in early 1969. ${ }^{3}$ This official visit was received with significant enthusiasm from segments of national public opinion which

\footnotetext{
${ }^{1}$ AUS, Fondo Luigi Papo, Busta 5, fasc, 50, "Letters to Nixon," 1969.

${ }^{2}$ ACS, PCM, Ufficio Consigliere Diplomatico, Busta 90, fasc.Trieste, "Chamber of Commerce and Trade to MAE," September 1, 1967.

${ }^{3}$ Bucarelli, ed. Perfetti (2011), 490-495.
} 
depicted it as the beginning of a new diplomatic process whose goal was the quick resolution of a wide range of pending bilateral problems. ${ }^{4}$ On the other hand, right-wing propaganda depicted the event as an "ignominy that offended the memory of the deaths of the "foibe." 5 Throughout the late 1960s and early 1970s these conflicting arguments repeatedly emerged within both national and local public discourse, ultimately aggravating the political debate over the Istrian problem.

Thus, in the early 1970s, the central government continued to firmly reassert its commitment to the preservation of Italian claims over the ex-zone B in public while privately undertaking secret negotiations. By doing so, it was greatly facilitated by the climate of international relaxation and the domestic shift toward the Communist Party which paved the way to the definitive recognition of Yugoslav sovereignty. This chapter focuses on the years from the Prague Spring to the 1975 Osimo Treaty and examines both the complex relationship between Trieste and Rome as well as the broader political process that led up to it. ${ }^{6}$ It suggests that the deceptive behavior of the Christian Democratic governing elites and Osimo's unclear economic benefits further weakened Trieste's loyalty to the Italian state and led to the emergence of a new political movement that radically challenged the Christian Democratic rule in Triestine politics.

\section{Consolidating the Adriatic Friendship: the Prague Spring and its Political Aftermath}

During the 1960s, the Christian Democrats' policy of both the center-left and Adriatic friendship encountered political and popular resistance. This was particularly true for Trieste, a city in which the division between "Morotei" and "Fanfaniani," supporters of Moro and Fanfani respectively, played a greater role than in the rest of the country. Segments of the local bourgeoisie and Istrians of center-left inspiration aligned with the "Morotea" faction of the party, which was willing to proceed with a final settlement of the eastern frontier by judicially recognizing Yugoslav

\footnotetext{
${ }^{4}$ Filippo Paliotta, "Un buon vicinato," Il Popolo (January 9, 1969).

5“"Una visita oltraggiosa," Il Secolo d'Italia (January 9, 1968).

${ }^{6}$ For a full version of the text of the Osimo Treaty, see

http://freeterritorytrieste.com/TREATIES/UN75111024848TRATTATOOSIMO.pdf and

http://freeterritorytrieste.com/TREATIES/UN75111024849TRATTATOOSIMO.pdf
} 
sovereignty over the ex-zone B. Others, instead, supported the "Fanfaniana" faction of the party and, therefore, supported the maintenance of Italian claims over the ex-zone B. This political division was best personified by its local leaders, Sergio Coloni and Giacomo Bologna, whose positions mirrored the views and approaches of the most progressive and conservative factions of the Christian Democrats. Interestingly enough, despite its geographical proximity to the border, Trieste was ruled by a "Morotea" Christian Democratic majority in which local Triestines outnumbered Istrians.

Outside of the party, associations such as the National Italian Irredentist Association (ANII) feared that the Christian Democrats were taking the party further to the left, greatly accelerating “the gradual, silent, and deceptive" renunciation of the ex-zone B. ${ }^{7}$ During the 1968 senatorial elections, members of the association sent a letter to Gianni Bartoli, a member of the executive committee of the National Association for the Adriatic Refugees, in which they urged him to tighten the local political forces of the center-right and oppose the possible affirmation of pro-Slovene and leftist candidates in Trieste. ${ }^{8}$ In his correspondence with the Christian Democratic national secretary Mario Scelba, Bartoli clearly stated that he feared the strengthening of the left in national politics and its detrimental effects on Trieste. Bartoli argued that the Yugoslav international strategy of peaceful coexistence ultimately aimed to "advance the Yugoslav national economy by suffocating the Triestine port economy.",9

The most progressive faction of the Christian Democrats repeatedly dismissed these arguments and instead highlighted the positive impact of the government's policies for Trieste. In his private correspondence with leading figures of the party, Coloni stressed that, although the CIPE plan had experienced some delay, the transformation of the shipyard industry had positively affected the Triestine economy. The government, however, still needed to introduce a set of economic policies that could effectively cope with the aging of the local population and the slight

\footnotetext{
${ }^{7}$ Piero Bruscaroli, "La questione adriatica è ancora aperta," Il Borghese (December 12, 1968).

${ }^{8}$ AUS, Fondo Luigi Papo, Busta 3, fasc. 18, "Letter to Bartoli," February 5, 1968.

${ }^{9}$ ASL, Fondo Mario Scelba, Versamento II, Corrispondenza, B.17, f.199, "Bartoli to Scelba," January 25, 1968.
} 
decline in both skilled and unskilled workers. To begin with, Coloni added, state institutions needed to integrate rather than assimilate the Slovene minority of the region both inside and outside Trieste. This strategy would ultimately strengthen the regional economy, improve relations between Slovenes and Italians, and also minimize local nationalist outbursts. At the same time, Coloni noted, the central authorities "had to protect the rights of the Italian minority in the ex-zone B, a problem that significantly affected the credibility of state institutions in Trieste."10

Coloni perceptively understood that the central government while restoring Trieste's port economy and weakening ethnic tension, also had to publicly support the rights of the Italian community still living in the ex-zone B. Indeed, a confidential report from the Italian Foreign Service reported that even in a city like Fiume where the Italian population had nearly disappeared, the emotional attachment to the idea of the Italian homeland still survived after years of Yugoslav repression. For example, during the meeting on October 4, 1969 at the Communist headquarters of Fiume, local Italians responded to the Triestine Communist delegation's harsh criticism of the Italian state by leaving the speech and voicing their disappointment. ${ }^{11}$

Most of the Italians living in Yugoslavia, however, were politically organized in the "Unione degli Italiani di Istria e Fiume" (Union of Italians in Istria and Fiume), an association which, according to the Triestine authorities, was gradually transformed by members of the Yugoslav Communist League into a mere tool of socialist propaganda. ${ }^{12}$ The association consistently stressed the failure of the Italian state to guarantee the protection of the minority rights of the local Italian community as well as the inability of the Italian administration to enforce the principle of reciprocity that underscored the London agreements of 1954. Trieste's former mayor, Bartoli, harshly criticized this association whose subservience to Tito's regime had long supported Yugoslav annexationist policies toward the ex-zone B. ${ }^{13}$ These accusations were further reiterated

\footnotetext{
${ }^{10}$ DT, Fondo Coloni, B.4, Folder 1968.

${ }^{11}$ UZC, Sezione IV, Busta 28, Vol.I, Folder Varie, "Confidential MAE to PCM," October 4, 1969.

${ }^{12}$ ACS, MI, Dipartimento della Pubblica Sicurezza, Cat.G, Associazioni, 1944-1986, B.363, Folder Unione degli Istriani dell' Istria e di Fiume, "CGFVG to PCM," March 2, 1968.

${ }^{13}$ AST, Fondo Bartoli, Busta 24, fasc.149, "Note on Unione Italiani," June, 1968.
} 
by the President of the National Venetia and Dalmatia Association (ANVGD), Paolo Barbi, who noted that the pro-Communist views of this association not only discredited its members, but, above all, sanctioned the definitive political isolation of about 26,000 Italians who were still living in Yugoslavia. $^{14}$

By 1968, the socio-political status of the Italian minority living under Yugoslav administration effectively remained a sensitive issue for the Italian government and was promptly exploited by the political opposition in Trieste. Intransigent nationalists like Bruno Coceani argued that the central government, while improving diplomatic relations with Yugoslavia, had pursued a set of mistaken economic policies which would ultimately result in the gradual "Slavization" of Trieste and the abandonment of any territorial claim over the ex-zone B. ${ }^{15}$ In his campaign for the ex-zone B, a few months before the Prague Spring, Coceani argued that the preservation of the status quo would preserve popular hope for the reintegration of the Istrian region within national borders after Tito's death and strengthen national security against a possible Communist threat. ${ }^{16}$

These arguments, however, hardly affected the Italian government which increasingly viewed the strengthening of the Adriatic friendship as the best means of opposing the Communist threat. The government's position was also largely shared by significant segments of national public opinion which remained unmoved by the neo-irredentist propaganda of both émigré and patriotic associations. In such a context, the conflicting relationships between the "Associazione Comunità Istriana" (Association of Istrian Communities, heir of the Istrian CLN), the "Lega Nazionale" (National League) and the ANVGD further weakened public support for the defense of Italian territorial rights over the ex-zone $\mathrm{B}$.

While both the ANVGD and the ex-Istrian CLN supported the new Christian Democratic policy of Adriatic friendship as well as a coalition government with the parties of the noncommunist left, the National League continued to firmly oppose any compromise with leftist parties

\footnotetext{
${ }^{14}$ AST, Fondo Bartoli, Busta 24, fasc.149, "Barbi to Bartoli," May 8, 1969.

${ }^{15}$ AST, Fondo Coceani, R/9, 565, January, 1968

${ }^{16}$ AST, Fondo Coceani, Serie 4, R/9, Fasc.565, Italia Irredenta, "Letter from Coceani to Ministry of Foreign Affairs Fanfani," February 8, 1968.
} 
and advocate the preservation of Italian formal claims to the ex-zone B. At the same time, however, this association repeatedly distanced itself from the revanchist claims of the neo-fascist movement whose territorial ambitions in the Adriatic region still called for an unrealistic revision of the Paris Peace Treaty and undermined reconciliation between national groups inside Trieste. ${ }^{17}$

In 1968, however, neo-irredentist claims were further debased by the Warsaw Pact invasion of Czechoslovakia which revived Italian fears of Soviet Communism. ${ }^{18}$ Tito's role as a buffer to contain Soviet aggressiveness persuaded the governing elites to decisively accelerate the resolution of the border dispute and ensure Italian national security along the Adriatic. From Italy's perspective, a permanent state border would consolidate Yugoslav political stability and alleviate Belgrade's fears. Indeed, the Yugoslav authorities had strengthened military security along the demarcation line, as they were increasingly concerned about the possible infiltration of anti-Titoist agents from the Italian border. ${ }^{19}$

Addressing the issue from Belgrade, Folco Trabalza, the Italian Ambassador to Yugoslavia, wrote to Foreign Minister Fanfani confirming that the Yugoslav leadership was experiencing the "psychosis of an external plot." 20 To mitigate these fears, Trabalza advised the central government to send Tito clear signals of political cooperation and support for the crumbling Yugoslav economy. Stronger Yugoslav involvement in the European markets would also work to advance Italian economic interests in the Balkans, Trabalza argued. Thus, the Italian government reassured Tito that, in case of Soviet aggression, Italy would not threaten the territorial integrity of the Yugoslav Federation in the Istrian region. ${ }^{21}$ This verbal commitment, which was warmly welcomed by Belgrade, ultimately confirmed the Italian government's unwillingness to challenge Yugoslav rule in the ex-zone B and demonstrated its future preparedness to renounce definitively claims to Italian sovereignty.

\footnotetext{
17، "Politica estera e diritti della minoranza," Il Lavoratore (January 28, 1968).

18،"Belgrado reagisce all'attacco sovietico," Il Piccolo (October 26, 1968).

${ }^{19}$ UZC, Sezione IV, Busta 28, Vol.I, Folder Arresto Floriano Antonio e Altri, "CGRFVG to PCM," September $28,1968$.

${ }^{20}$ ACS, PCM, Ufficio Consigliere Diplomatico, Busta 66, Sfasc.6, “Trabalza to Fanfani," May 9, 1968.

${ }^{21}$ Segni confirmed Fanfani that Tito expressed concern for a possible Soviet invasion. ASR, Sezione IV, Diari Fanfani, September 13, 1968.
} 
Although most of Italy's governing elite firmly supported Yugoslav geo-political stability, a small minority still feared a possible yet very unlikely Soviet-Yugoslav alliance and rhetorically portrayed Trieste as the Western stronghold against international Communism. During the crisis of the Prague Spring members of the Foreign Ministry in Rome sent a secret telegram to the Italian Embassy in Belgrade which equated "Adriatic irredentism with liberty and progress for the population of the Adriatic region." In promoting ideas of freedom by means of Italian language and culture, the telegram continued, the preservation of the region's Italian cultural legacy was particularly significant to oppose advancing Communism. ${ }^{22}$ This view, also shared by moderate segments of the neo-irredentist movement, emphasized the defense of Italian cultural as well as linguistic rights and, far removed from past expansionist territorial ambitions, diverged from the nationalist rhetoric of its neo-fascist wing.

Although these groups had experienced increasing political isolation inside and outside the neo-irredentist network, Soviet intervention in the Prague Spring had largely benefited its propaganda. ${ }^{23}$ In frontier cities like Trieste, neo-fascism sought to use past fears of the combined threat of both Yugoslav Communism and Slav nationalism to gain popular support. ${ }^{24}$ In a climate of anxiety and insecurity, neo-fascists created small military cells that, located on the Carsic hills, were prepared to confront a possible Yugoslav invasion. ${ }^{25}$ Terrorist organizations such as "Ordine Nuovo" (New Order), a movement that was inspired by the revolutionary program of fascist syndicalism, would have been able to mobilize up to 3,500 people inside Trieste. ${ }^{26}$ Its extremist tone and agenda, however, detrimentally affected popular support for the neo-Fascist Party (M.S.I.). ${ }^{27}$

\footnotetext{
${ }^{22}$ ACS, Carte Moro, Ministero Affari Esteri 1973-1974, Busta 163, Jugoslavia Questione Territoriale, "Telegram 7694," April 30, 1968.

${ }^{23}$ Panvini, 248.

${ }^{24}$ Scaliati, 90-94.

${ }^{25}$ AFG, Fondo Apc, RP, MF0306, p.2432, “Segreteria Triestina PC al Comitato Centrale PCI,” June 17, 1969.

${ }^{26}$ Led by the ex-Salò Pino Rauti, "Ordine Nuovo" was created in 1953 from dissidents of the MSI. ACS, MI, Gabinetto, Fasc. Correnti, 1967-1970, B.25, MSI, Folder Ordine Nuovo, "Note from Division for Public Security," August 25, 1966.

${ }^{27}$ ACS, MI, Gabinetto, Fasc. Correnti, 1967-1970, B.18, MSI, Fasc. 195/P/85, December 21, 1970.
} 
The responses of the most radical fringes of the neo-irredentist network were strongly motivated by ideological precepts and, above all, the desire to exploit local animosity toward Tito's regime. In this fashion, the National Italian Irredentist Association, which was eager to benefit from the Soviet-led invasion of Czechoslovakia, decided to organize its national convention in Trieste. The convention coincided with the fiftieth anniversary of the end of World War One which became objects of dispute between the National Italian Irredentist Association and the Italian government. Since the central government decided to neglect cities like Pola, Zara, or Fiume from the official celebration, neo-irredentists accused the Christian Democrats of subservience to the politics of relaxation. ${ }^{28}$ Thus, when the "Unione Istriani" also organized its national convention in Trieste in 1968, the Italian Foreign Ministry discouraged the central government from authorizing the event. In contrast, Minister of Interior Paolo Taviani claimed "deep trust in the behavior of the 50,000 émigrés who populated Trieste. ${ }^{, 29}$ Only after months of uncertainty and discussion of the precise themes and tones of the planned meeting, the national government authorized the event. ${ }^{30}$

The Istrian convention saw the massive participation of both émigrés and Army veterans who repeatedly emphasized their invaluable roles in the fulfillment of national unity and the defense of national territorial interests along the Adriatic border. Moreover, nationalist rhetoric pervaded the speeches of prominent political figures. For example, Gianni Bartoli defined Istria as a "distinct yet not detached part of the nation" which was indissolubly tied to the Italian community for economic, political, and moral reasons. The former mayor of Trieste then argued that the legacy of democratic irredentism, stemming from the experience of national Risorgimento, supported the peaceful revision of the Paris Peace Treaty and the rights of the Italian border community to selfdetermination. $^{31}$

\footnotetext{
${ }^{28}$ AUS, Fondo Luigi Papo, Busta 3, fasc.18, "Telegram to Ministry of Defense," September 5, 1968.

${ }^{29}$ ACS, MI, Dipartimento della Pubblica Sicurezza, Cat.G, Associazioni, 1944-1986, B.363, Folder Unione degli Istriani, "Confidential Notes and Correspondence CGFVG, MI, MAE," January-November, 1968.

${ }^{30}$ ACS, Carte Moro, PCM, Ufficio Consigliere Diplomatico, Busta 49, "Pompei al Ministro Affari Esteri," April 20, 1968.

${ }^{31}$ AST, Fondo Bartoli, Busta 4, Discorsi, 1968.
} 
Admittedly, personalities like Bartoli, who had shown strong democratic sentiments, still saw the Adriatic border that extended from Trieste to the Istrian region as a cultural and territorial space of indisputably Italian rather than European identity. In his view, the preservation of the geopolitical status quo of the Triestine territory would save its acclaimed "Italianità" and connect the Italian population living across the border to the rest of the nation. Despite the local strength of these views, the émigrés' ability to rally people around the irredentist flag outside Trieste was decisively impaired by the increasingly weak effect of patriotic rhetoric. ${ }^{32}$

Although the campaign for the ex-zone B had gradually lost resonance with the public, it was still being used as a valuable political tool to prove the Roman authorities' inability to cope with the problems of the Adriatic border in Trieste. To respond to local criticism, the Christian Democrats sought to strengthen local political support by including Slovene party formations within the 1969 coalition government with Socialists and Republicans. ${ }^{33}$ This political move was supported by the "Morotea'" fringe of the national Christian Democratic Party whose progressive strategy both in domestic and foreign policy had met increasing popular support outside Trieste. ${ }^{34}$

At the same time, however, this policy provoked the opposition of a variety of right-wing extremist formations, among them the "Associazione Fronte Nazionale" (National Front Association, AFN). This association, under the leadership of Valerio Borghese, ex-commander of the X-MAS and leading member of the National Italian Irredentist Association, relied on the support of past members of the former fascist Republic of Salò, dissidents of the neo-Fascist Party (MSI), industrial entrepreneurs, and right-wing Masonic groups. In 1969, the AFN and the National Italian Irredentist Association coordinated a mass demonstration in Rome which called for "the return of the unredeemed lands of Istria and Dalmatia under Italian sovereignty." ${ }^{35}$ Although the

\footnotetext{
${ }^{32}$ AUS, Fondo Luigi Papo, Busta 2, fasc.6, "National Assembly," November 3, 1968.

${ }^{33}$ DT, Fondo Coloni, B.4, Folder 1970.

${ }^{34}$ Ungari, ed. Perfetti, 246.

${ }^{35}$ ACS, MI, Dipartimento della Pubblica Sicurezza, Cat. G, Associazioni 1944-1986, B.291, Associazione Fronte Nazionale, "Report from Rome’s Chief of Police," March 13, 1969.
} 
nationalist press celebrated the demonstration and its popular massive participation in it, it generally went unnoticed by national public opinion.

As discussed, neo-irredentist rhetoric in support of the ex-zone B had little effect on popular sentiments, especially outside Trieste and after the Prague Spring. At this time, Tito was increasingly perceived within public discourse as a valuable partner in countering the Soviet threat within public discourse. Thus, the progressive views of the Christian Democratic government and its allies increasingly clashed with those of both moderate and extremist elements of the neoirredentist network. Meanwhile, diplomatic negotiations over the ex-zone B significantly accelerated.

\section{Moving Further the London Memorandum}

Over time, the idea of all-embracing negotiations to finally settle the territorial dispute over the ex-zone B had significantly strained political relations between the central government and its political opposition. In addition, the search for a formal agreement with Tito's Yugoslavia increasingly divided the progressive and conservative factions of the Triestine Christian Democrats, especially in Trieste. ${ }^{36}$ In response to the increasing discord within the party, Mario Scelba, former Prime Minister during the negotiation of the London Memorandum, invited the party's elites to recreate an internal committee that would draw up a single and unequivocal agenda in foreign policy and avoid internal factionalism. ${ }^{37}$

The political opposition indeed exploited the divergence of views inside the Christian Democrats to criticize the central government and its policy toward the border. They argued that the government, by adopting the new policy of Adriatic friendship, would ultimately renounce "legitimate Italian claims" over the Istrian region. ${ }^{38}$ In addition, liberal political leaders argued that even if Moscow threatened Yugoslav independence, the Italian government should not renounce its

\footnotetext{
${ }^{36}$ AST, Fondo Bartoli, Busta 98, Corrispondenza, "Letter from Ministry of Agriculture and Forestry to Bartoli," January 8, 1969.

${ }^{37}$ ASL, Fondo Mario Scelba, Versamento II, B.4, f. 69, "Scelba to Bernassola," February 3, 1969.

38، Nenni a Belgrado per tradire la zona B," Il Secolo d'Italia (May 27, 1969).
} 
territorial interests along the Adriatic. ${ }^{39}$ These views were greatly shared by the conservative segments of the Italian community in Trieste which understood the 1969 visit of Italian Foreign Minister Pietro Nenni to Yugoslavia as a prelude to the recognition of Yugoslav sovereignty over the ex-zone B. ${ }^{40}$ Effectively confirming these fears, the Italian Consul in Capodistria praised the positive effects of the Christian Democratic-led coalition of the center-left on Italian-Yugoslav relations. In his report to his superiors in Rome, he stated that the spirit of Adriatic detente had fostered cooperation between Italian and Slovene socialists both in Gorizia and Trieste and, above all, "exposed the anachronism of whoever was still anchored to nationalist myths and theories of limited sovereignty." ${ }^{41}$

This report confirmed that reasserting Italian formal territorial rights over the ex-zone B was no longer a part of the government's agenda. During his visit to Yugoslavia in September 1969, Moro revealed the intentions of the Italian government. The diplomatic talks, while covering a broad set of political and economic issues, also extended to the sphere of security and cooperation in Europe. As confirmed in a secret telegram sent from the Italian Embassy in Belgrade to Rome, both Italian and Yugoslav delegations agreed to proceed cautiously with confidential talks between Italian vice-director of Political Affairs Luigi Milesi Ferretti and Yugoslav Ambassador Zvonko Perisic on the major unresolved territorial issues. ${ }^{42}$

As expected, Moro's visit to Belgrade was criticized by both the National Italian Irredentist Association and the Istrian Union which refused to accept any change to the status quo of the zone B. ${ }^{43}$ In its telegram to the main political parties, patriotic associations, and national newspapers, the National Italian Irredentist Association claimed that, acting as heads of the national government at different times, both Moro and Fanfani had been committed to the defense of Italian territorial sovereignty over the ex-zone B. Therefore, it continued, the government had to uphold its former

\footnotetext{
${ }^{39}$ FN, Carte Nenni, B.60, Sez. C 1961-1969, Riservatissima "Cantalupo to Nenni," May 29, 1969.

${ }^{40}$ "Nel clima di buon vicinato la visita di Nenni a Belgrado," Il Piccolo (May 26, 1969).

${ }^{41}$ UZC, Sezione IV, Busta 28, Vol. I, Folder Varie, "Consulate of Capodistria to PCM," May 31, 1969.

${ }^{42}$ ACS, Carte Moro, Ministero Affari Esteri 1969-1972, Questioni Nazionali e Internazionali, Busta 148, Fasc. 12

Telegrammi in Arrivo, Riservatissimi, Segreti e Segretissimi, "Segretissimo 42076," October 10, 1969.

${ }^{43}$ Chino Alessi, "Dal buon vicinato nascerà l'amicizia," Il Piccolo (October 8, 1969).
} 
claims and oppose the ongoing de-Italianization of the Istrian region which had experienced the unforgivable tragedy of the "foibe." ${ }^{44}$ As in the past, the neo-irredentist associational network used the "foibe" to legitimize Italian territorial claims as a form of compensation for war-time Yugoslav violence and its opposition to the process of “peaceful coexistence" with Tito's regime. ${ }^{45}$

The steady improvement of economic and political relations, however, had allowed Italy and Yugoslavia to overcome past tensions and create the "most open border of Europe." ${ }^{46}$ From the perspective of the Italian government, the new climate of "Pax Adriatica" provided the ideal context to foster cross-cultural relations, pave the way for Tito's visit to Italy, and resolve unsettled issues. ${ }^{47}$ By contrast, war-veteran associations centered their propaganda upon figures like D'Annunzio to claim the undisputable Italian nature of the Istrian region under Yugoslav administration. ${ }^{48}$ Likewise, the Istrian Union promoted cultural events which, publicly presented as the highest expression of patriotism and sacrifice, underscored the legacy of Adriatic irredentism and hoped to reinvigorate the increasingly weak ideals of homeland within local and national public opinion. ${ }^{49}$

In the late 1960s, however, the broad use of political violence by right-wing extremist movements strongly discredited patriotic rhetoric, especially in Trieste. In November 1969, for example, the Triestine police found a deposit of explosive materials, weapons, and munitions in a cave about twenty kilometers from city. The ownership of the arms was attributed to one of the neofascist youth organizations that operated on the border. In addition, the following month the Triestine police arrested a group of local neo-fascists who were accused of bombing a Slovene school. During these investigations, the local police also determined that, contrary to the propaganda of the National Italian Irredentist Association, no Italian irredentist cells were operating inside Yugoslavia. Indeed, the Italian minority in Yugoslavia was not carrying out any organized

\footnotetext{
${ }^{44}$ AUS, Fondo Luigi Papo, Busta 2, fasc.8, "Telegram from National Secretary Borghese," September 19, 1969.

45،"Totale diversità di vedute tra Italia e Jugoslavia," Il Secolo d'Italia (October 5, 1969).

${ }^{46}$ Franco Petrone, "Saragat oggi a Belgrado," L'Unità (October 2, 1969).

${ }^{47}$ Marcello Gilmozzi, "Oggi Saragat conclude la visita in Jugoslavia,” Il Popolo (October 6, 1969).

${ }^{48}$ AUS, Fondo Luigi Papo, Busta 3, fasc. 19, "Papo to De Cesaris," September 4, 1969.

${ }^{49}$ AUI, 1967-1987, Busta 20, Folder 5/49, "Schedario Irredentismo," 1970-1973.
} 
terrorist actions in support of Italian irredentist ambitions. ${ }^{50}$ Although the police demonstrated the merely propagandist nature of the claims of the National Italian Irredentist Association, progressive media used this information as well as the aforementioned activities of neo-fascist groups to highlight the extremist nature of both émigrés and patriotic associations in Trieste.

To counter these claims, local neo-fascist groups attacked the Christian Democrats for their acquiescence toward the communist party which was accused of having betrayed Trieste's "Italianità" and cooperatinig with Tito during the tragedy of the "foibe." ${ }^{51}$ Although the central government had certainly shown a compromising attitude toward the Italian Communist Party, the most conservative factions of the Christian Democrats still harbored suspicion of its intentions. In his diary, Fanfani noted that the PCI, strongly supported by Moscow, planned to take control of the government by increasing commercial ties with the Soviet Union, controlling regional councils and trade unions, and finally by exploiting its popularity among soldiers in the national Army. ${ }^{52}$

These views revealed the long-standing effects of the climate of Cold War on leading figures of the central government. At the same time, they also explain why the Italian state continued to financially support anti-communist associations of Christian Democratic orientations. ${ }^{53}$ In Trieste, over time, anti-communist rhetoric and wartime memories had been used to infuse popular attitudes with hostility toward Tito and his regime.

\section{Tito's Visit: Bringing the Zone B Back within National Political Discourse}

By the late 1960s, the preservation of the Italian culture and language within the Triestine territory and the restoration of its port's prosperity had become complementary to any renunciation of Italian sovereignty over the ex-zone B for the Italian government. Indeed, any change in the geo-

\footnotetext{
${ }^{50}$ ACS, MI, Dipartimento della Pubblica Sicurezza, Cat.G, Associazioni, 1944-1986, B.357, Folder Organizzazione di Azione Patriottica, "Confidential Note from Triestine Police," November 27, 1969.

${ }^{51}$ ISRML, Fondo Poli, Busta 2, fasc. 24, Flyer "Fronte della Gioventú," 1969.

${ }^{52}$ ASR, Sezione IV, Diari Fanfani, "Picella to Fanfani," December 6, 1970.

${ }^{53}$ For example the "Associazione Volontari della Libertà" and "Associazione Nazionale Ragazzi del '99" were steadily financed by the Christian Democrats to spread the values of democratic patriotism and National resistance. UZC,

Sezione V, Busta 10, Folder Associazione Volontari della Libertà ex Ass. Partigiani Italiani.
} 
political status of the eastern border required some form of economic or political compensation; otherwise, it would be locally understood as proof of the state's indifference to Trieste's problem and strengthen local support for neo-irredentism, ultimately affecting Italian-Yugoslav relations.

In 1970, public discourse regarding the ex-zone B had crystallized around two irreconcilable positions. Center-left political parties and associations advocated the formal resolution of a senseless dispute whose terms had informally been resolved in 1954 and created the most open border in Cold War Europe. ${ }^{54}$ On the other side, center-right political parties and associations reasserted claims to formal territorial rights over the northern part of the Istrian region and stressed the negative effects of a definitive border that would physically separated Italians across the Adriatic. ${ }^{55}$ The demarcation line rather than a definitive state border, neo-irredentists argued, represented the best means to guarantee peaceful coexistence with Tito's regime.

Religious figures such as Bishop Santin had traditionally embraced these views. Thus, in February 1970, the news of Santin's possible resignation as Bishop of the Triestine diocese fostered a sense of disappointment inside the Adriatic city. In a private letter to the Pope, Bartoli begged the Pontiff “not to accept Santin's resignation, a fact that would further weaken the rights of the Italian minority living in the ex-zone B under an ignoble Socialist regime." ${ }^{\circ 6}$ These arguments were also echoed within the pages of both the nationalist and émigré press which publicly advertised the imminent separation of the dioceses of Trieste and Capodistria as a sign of the definitive partition of the ex-zones $\mathrm{A}$ and $\mathrm{B}^{57}$

Thus, in March, when the Yugoslav press agency "Tanjug" reported that the Croatian Communist party considered the political and territorial status of the ex-zone B under Yugoslav control unchangeable, the Istrian Union called upon the national government to release an official declaration disproving Yugoslav claims. ${ }^{58}$ In denying the claim of Yugoslav annexation, the Italian

\footnotetext{
54،"Efficace collaborazione fra italiani e sloveni," Il Popolo (December 1, 1970).

55،"Il centrosinistra prepara la cessione della zona B," Il Secolo d'Italia (December 1, 1970).

${ }^{56}$ AST, Fondo Bartoli, Busta 30, fasc.202, "Bartoli to Pope," February 1, 1970.

${ }^{57}$ Corrado Belci, Trieste memorie di trent'anni (1945-1975) (Brescia: Morcelliana, 1989), 188.

${ }^{58}$ AUI, 1967-1987, Busta 17, Folder 5/1/3, "Il problema della zona B," March 27, 1970.
} 
government's response was well received in Trieste, especially among the 60,000 émigrés from Istria and Dalmatia and their associations. Although the national government dismissed rumors about the imminent partition of the Adriatic border, it also sought to accelerate the recognition of Yugoslav sovereignty over the ex-zone B. As it happened in the past, the central government significantly reduced financial support for both émigré and patriotic associations that opposed the final settlement of the issue. ${ }^{59}$ Associations like the ANVGD, therefore, experienced a net decrease in government's contributions and were able to only partially assist the émigrés in their struggle to receive compensation for their lost properties and to maintain traditional recreational and cultural activities. $^{60}$

All of these factors certainly increased the émigrés' opposition to the course of events, which rose exponentially in October 1970 when Tito officially announced his visit to Italy. ${ }^{61}$ In his private correspondence with the President of the National Italian Irredentist Association, Gianni Bartoli stressed that the growing apathy of national public opinion toward the issue of the ex-zone B had endangered Italian territorial rights and, therefore, neo-irredentist associations should give Tito a "glacial welcome." ${ }^{62}$ Also firmly opposing Tito's visit, right-wing war veteran associations decided to hold thier national meeting in Trieste and claimed that "Italian territorial sovereignty over Istria was undisputed and further legitimized by the personal sacrifices of the Italian minority that became victims of Tito's crimes.",63

The neo-irredentist campaign against Tito's visit and its detrimental effect on Italian territorial claims over the ex-zone B was echoed elsewhere. For example, in one of its articles, the conservative Roman newspaper Il Tempo associated Tito's visit with the existence of ongoing negotiations between Italy and Yugoslavia over the definitive settlement of the Eastern border. This news was widely advertised by the émigré press as well as media, political parties, and movements

\footnotetext{
${ }^{59}$ ALN, Folder 1971/III, "Verbali Consiglio Direttivo Centrale 1968-1971," October, 1970.

${ }^{60}$ UZC, Sezione V, Busta 18, Folder ANVGD, "Contributions 1970-1975."

${ }^{61}$ Pino Romualdi, “Tito, l'Italia e l'occidente," L'Italiano (December, 1970).

${ }^{62}$ AUS, Fondo Luigi Papo, Busta 3, fasc.20, "Confidential pro-Memoria per la visita di Tito," October 9, 1970.

${ }^{63}$ ALN, Folder 1970/1, Segreteria Luglio-Dicembre 1970, "Press Release from Federazione Nazionale Arditi e Combattenti," November 10, 1970.
} 
of the center-right. The Istrian Union in particular, mobilized against any territorial concession to Tito's regime by actively coordinating its propaganda both at home and abroad in countries such as the United States, Australia, and Argentina. The association, while sending telegrams and letters to both national and local authorities, also established committees for the defense of the zone B and Istria. ${ }^{64}$ The émigré campaign proved successful and the national secretary of the Christian Democrats, Arnaldo Forlani, promised the President of the Istrian Union, Sardos Albertini, to exercise political pressure on the Ministry of the Foreign Affairs to reassert Italian claims to sovereignty over the ex-zone $\mathrm{B}^{65}$

In their public campaign for the ex-zone B, the Istrian émigrés were strongly supported by right-wing political parties and movements, in particular the neo-Fascist Party (MSI) and the National Italian Irredentist Association (ANII) ${ }^{66}$ In Trieste, they were also supported by the local newspaper, Il Piccolo, which opposed any change to the status quo in the ex-zone B. ${ }^{67}$ In anticipating Tito's visit, the ANII planned to prepare about 50 to 60 thousand flyers with a quotation from Gianni Bartoli which described the possibility of Yugoslav sovereignty over the ex-zone B as an "offense to those who live and an outrage to those who have died." The association also planned to distribute 5-10 thousand postcards as well as 25,000 stamps with images recalling the Italian past of Istria. In addition, it intended to send a series of letters to national media and relevant political personalities to advertise widespread popular opposition in Trieste toward Tito's visit. ${ }^{68}$ Aware of the widespread distrust for nationalist movements by significant segments of national public opinion and considering the positive views and international credibility acquired by Tito, the association decided to carefully control its protests. Above all, it attempted to prevent political violence by pre-emptively condemning it, as incidents would further jeopardize its already crumbling popularity.

\footnotetext{
${ }^{64}$ ALN, Folder 1970/1, Segreteria Luglio-Dicembre 1970, “Appello agli amici dell’Istria italiana,” November $28,1970$. ${ }^{65}$ AUI, 1967-1987, Busta 17, Folder 5/1/8, "Un primo importante successo," December 7, 1970.

${ }^{66}$ AUI, Miscellaneous, Folder rapporti con i partiti, Fasc. 2.6, "Almirante to Sardos Albertini," December 9, 1970.

${ }^{67}$ ACS, MI, Dipartimento della Pubblica Sicurezza, Cat.G, Associazioni, 1944-1986, B.363, Folder Unione degli Istriani, "Pamphlet la nostra comune azione ha salvato la zona B," December 1970-January, 1971.

${ }^{68}$ AST, Fondo Bartoli, Busta 170, Rapporti Mondo Esuli, "Note from Renzo Migliorini," October 7, 1970.
} 
Meanwhile, in Trieste, émigré and patriotic associations organized demonstrations against Tito's visit. Although these associations had over time manufactured a sense of threat to resist any change to the status quo over the ex-zone B, they were generally moderate in their tactics and opposed the instrumental use of the ex-zone B to legitimize outbursts of neo-fascist violence. ${ }^{69}$ Nonetheless, during the Triestine rally which was attended by about 2,000 people, the local protests quickly escalated into violence in which neo-fascists targeted both members of the Slovene minority and leftist organizations. ${ }^{70}$

Following the Triestine demonstration, Corrado Belci, the leading voice of the "Morotea" faction of the Triestine Christian Democrats, criticized the conservative views of local as well as national political leaders who proved unable to understand the positive effects of Tito's visit on both Italy's international credibility and national economic policies toward the Adriatic. ${ }^{71}$ These views, however, were firmly opposed by figures like Gianni Bartoli who identified with the conservative faction of the Triestine Christian Democrats and shared the views of figures such as Amintore Fanfani or Giacomo Bologna. In his letter to local Christian Democrat GiorgioTombesi, Bartoli emphasized that "eight years of failing Christian Democratic policies had resulted in both the rise of Slav and socialist political parties as well as an excessive acquiescence toward Tito.”72 As these statements suggest, opposition in Trieste to the progressive experiment of the center-left and closer relations with Yugoslavia certainly fed into popular animosity toward Rome.

A few days before Tito's visit, President Moro, eager to minimize both popular and political protests, restated the unchanged judicial status of the ex-zone B. ${ }^{73}$ This statement, while responding to the wishes of the émigrés and also decisively appeasing the most conservative factions of both local and national public opinion, clashed with the views of leftist parties which had long

\footnotetext{
69،'Si costituiscono i comitati per la difesa della Zona B,” Il Piccolo (December 6, 1970).

${ }^{70}$ ACS, MI, Gabinetto, Fasc, Corrrenti, B.102, Fasc.12010/85, Trieste e Provincia Attività dei Partiti, "Telegram to Gabinetto," December 8, 1970.

${ }^{71}$ ACS, Carte Moro, Atti Personali 1964-1977, Busta 177, Fasc.32, "Belci to Moro," December 10, 1970.

${ }^{72}$ ASL, Fondo Democrazia Cristiana, Segreteria Politica Forlani, Corrispondenza con gli Organi Periferici, Sc.198, Fasc.1, "Bartoli to Tombesi," December 11, 1970.

${ }^{73}$ Chino Alessi, "I legittimi interessi," Il Piccolo (December 10, 1970).
} 
recognized Yugoslav sovereignty over the ex-zone B. ${ }^{74}$ Above all, Moro's statement provoked Tito. ${ }^{75}$ Indeed, the Yugoslav President reiterated his personal criticism of Italy's inconceivable irredentist ambitions toward the ex-zone B and, consequently, decided to cancel his visit. ${ }^{76}$

A study of the main responses from the Italian newspapers to this news show the highly politicized nature of the issue which had become a powerful tool in the hands of the political opposition to dispute the acquiescence of the government toward mounting communism or resurgent neo-fascism. This news was indeed celebrated by the nationalist fringes of the Italian press which praised the pivotal role of the neo-fascist party rather than the pro-leftist government in defending Italian claims to the eastern border. ${ }^{77}$ The communist press, for its part, accused neofascists and the most conservative segments of the Christian Democrats of having forced Prime Minister Moro to proclaim the unchangeable nature of the border, despite the fact that both governments had been negotiating the border issue since $1969 .{ }^{78}$ Among these interpretations, which were driven by irreconcilable ideological views, moderate and progressive segments of national public opinion interpreted the cancellation of Tito's visit as the result of a mutual misunderstanding and greatly related it to the problematic nationality issue inside Yugoslavia. ${ }^{79}$

Meanwhile, Italians in Trieste responded to Tito's prospective visit in different ways. Triestine residents of progressive views, for example, responded to the appeal of local center-left parties and associations by condemning recent neo-fascist violence in the city with a mass demonstration that took place on December 14, 1970 and was attended by 15,000 people, a number that greatly surpassed the anti-Tito demonstration. ${ }^{80}$ While proving that post-war Trieste had moved forward in the process of democratization, the December 14 gathering also revealed local

\footnotetext{
${ }^{74}$ ACS, MI, Schedario Fascicoli Classificati, Partiti-Movimenti Politici 1971-1975, Faldone 3, Fasc. 160.P.187, PCI Trieste, "Confidential Note Commissariate Government FVG," January 24, 1971.

${ }^{75}$ Alfred Friendly, "Tito Put Off Italy Trip, Apparently Over Trieste," The New York Times (December 10, 1970).

${ }^{76}$ Bucarelli, ed. Perfetti, 500.

77،"Tito resta a casa," Il Secolo d'Italia (December 10, 1970).

${ }^{78}$ Franco Bertone, "Il viaggio mancato del Presidente Tito," Rinascita (December 18, 1970).

${ }^{79}$ Marcello Gimozzi, “Temporaneo rinvio della visita di Tito," Il Popolo (December 10, 1970).

80“'14 dicembre: Trieste ha voltato pagina," Il Lavoratore (December 24, 1970).
} 
antagonism toward forms of resurgent Fascism, a fact that was also positively received in Yugoslavia. $^{81}$

At the same time, émigré associations in Trieste, while receiving Tito's decision to cancel his visit to Italy positively, also exposed their concerns for the temporary success that still left future changes to claims of Italian sovereignty over the ex-zone B possible. Thus, the President of the Istrian Union, Sardos Albertini, argued that the national Istrian committees would continue to strictly monitor the actions and statements of both Italian and Yugoslav governments. ${ }^{82}$ In 1971, the Istrian Union created the "Centro Nazionale di Coordinamento per la Difesa Zona B e Istria" (National Center for the Coordination of the Defense of Zone B and Istria, hereafter C.N.C.). ${ }^{83}$ This new organization, whose members came from right-wing and Catholic political orientations, coordinated the efforts of the neo-irredentist network against any formal renunciation of Italian sovereignty over the ex-zone B. ${ }^{84}$ For example, the C.N.C. directly sent letters and telegrams to Italian politicians, calling upon them to defend the country's territorial claims. Such letters also denounced the Italian Foreign Ministry for its presumed complacency with the annexationist goals of the Yugoslav government. ${ }^{85}$

Following Tito's cancelled visit, local fears of a possible renunciation of Italian sovereignty to the Istrian region was again heightened by the controversial declaration of local judge Alberto Mayer. ${ }^{86}$ In his claims that "the foibe represented an act of revenge against years of fascist violence," Mayer implicitly justified Yugoslav war-time violence. His statement elicited a vehement and outraged reaction from many public figures in Trieste. ${ }^{87}$ In a series of letters to the national government, Bartoli also condemned the declaration which he believed derived from a

\footnotetext{
${ }^{81}$ ACS, MI, Gabinetto, Fasc, Corrrenti, 1971-1975, B.455, Fasc.15250/3, Radio Capodistria, "Rubrica le località vicine," December 19, 1970.

${ }^{82}$ Roberto Spazzali, "Prima e dopo Osimo: gli italiani in Istria," in Trieste 1900-1999, Cent'anni di storia, vol. IX, ed. Licio Bossi e Severino Baf (Trieste: Publisport, 2000), 199.

${ }^{83}$ AUI, Fondo C.N.C., Serie A, “Atti Organizzativi,"1971-1975.

${ }^{84}$ ACS, MI, Dipartimento della Pubblica Sicurezza, Cat. G, Associazioni 1944-1986, B.300, Folder Centro Nazionale di Coordinamento per la Difesa Zona B, "Note from Prefect of Trieste," May 29, 1971.

${ }^{85}$ AUI, Fondo C.N.C. Busta 3, Folder C/3, "Albertini to National Representatives," January 11, 1971.

${ }^{86 ، " F o r t e ~ a t t a c c o ~ a l ~ P G ~ d i ~ T r i e s t e, " ~ L ' U n i t a ̀ ~(J a n u a r y ~ 20, ~ 1971) . ~}$

${ }^{87}$ AST, Fondo Bartoli, Busta 69, fasc.152, "Bartoli to President of Ministry of Justice," January 16, 1971.
} 
broader and unacceptable national campaign against Trieste. ${ }^{88}$ In addition, Bartoli noted, the issue of the ex-zone B further reinvigorated local concern about the pace and depth of commercial agreements with Yugoslavia. According to Bartoli, the government's strategy, which claimed to integrate Trieste into the European market, had gradually strengthened the competitiveness of both Fiume and Capodistria, a situation that ran against the Trieste port's economic interests. ${ }^{89}$ These economic concerns, as cited by Bartoli, had over time reinforced local negative attitudes toward both the process of Adriatic friendship and center-left coalition governments. In addition, it facilitated the rise of the "Fanfaniani" faction of the Triestine Christian Democrats which, according to local state authorities, further strained relations between Triestine and Roman political governing elites. $^{90}$

Despite the intensity of the local political debate that followed the cancellation of Tito's visit, political parties and public opinion outside Trieste increasingly considered the issue of the exzone B as anachronistic. Indeed, many observers viewed West Germany's formal recognition of the Oder-Neisse line as a political decision that further reinforced Moro's aspiration of an Italian "Ostpolitik" toward Yugoslavia. In addition, the fact that in 1971 also the Vatican established diplomatic relations with Yugoslavia, a socialist country, decisively enhanced the image of Tito's regime. ${ }^{91}$ Thus, in the early 1970 s, crucial changes in international politics and the prospective inclusion of the Italian Communist Party into the coalition government further pressured the Christian Democrats to remove the issue of the ex-zone B from the international agenda. ${ }^{92}$

At this point, even the most progressive and moderate fringes of the local Italian community in Trieste increasingly understood the London Memorandum as a permanent rather than provisional agreement. In the words of Triestine poet Umberto Saba, the London Memorandum had served as an antidote to ethnic passion in a frontier region where, "patriotism, nationalism, and racism are

\footnotetext{
${ }^{88}$ AST, Fondo Bartoli, Busta 69, fasc.152, "Bartoli to President of Council Colombo," January 15, 1971.

${ }^{89}$ AST, Fondo Bartoli, Busta 69, fasc.152, "Bartoli to Andreotti," January 21, 1971.

${ }^{90}$ ACS, MI, Schedario Fascicoli Classificati, Partiti-Movimenti Politici 1971-1975, Faldone 7, Fasc. 165/P/87, DC

Trieste, "Confidential Commissariat Government FVG to PCM," February 22, 1971.

${ }^{91}$ Marcello Gilmozzi, “Un'esempio per l'Europa l'amicizia italo-jugoslava,” Il Popolo (March 28, 1971).

${ }^{92}$ Franco Soglian, “Tito, zona B, e interessi nazionali,” Il Ponte (March, 1971).
} 
related like health, neurosis, and craziness." ${ }^{93}$ From this perspective, the transformation of the demarcation line between Trieste and the ex-zone B into a state border appeared a mere matter of time. The Venice meeting of 1971 between Italian Foreign Minister Aldo Moro and Yugoslav Foreign Minister Mirko Tepavac removed the last obstacle that had stood in the way of Italian and Yugoslav diplomatic relations. During this meeting, Moro confirmed the territorial status established by the London Memorandum and, although local public opinion was not yet willing to accept a definitive renunciation, agreed to begin secret negotiations; an agreement on the ex-zone B would be announced at a more appropriate moment in the future. ${ }^{94}$

During the meeting Moro also suggested that Tito visit make a state visit to Italy, and in March 1971 the Yugoslav leader came to Rome. Sardos Albertini invited his fellow Istrians to accept Tito's visit yet part of the émigré community were still opposed to the idea of an official visit by the Yugoslav dictator as they considered him most responsible for the drama of the exodus and the "foibe." "95 In an exchange of letters with Bishop Santin, who will later retired in 1975, Albertini requested the Triestine Bishop to prepare a specific memorandum calling for the defense of Italian territorial rights over the ex-zone $\mathrm{B} .{ }^{96}$ While granting his support and contribution to both émigré and patriotic associations, Santin also revealed deep distrust toward the defeatist attitudes of the Italian authorities by stating that the government was giving Yugoslavia "what does not belong to it." 97

Meanwhile, foreign newspapers such as The New York Times, described Tito's March 1971 visit the act as an example of socio-political reconciliation and fruitful economic relations between countries with a conflicted past. ${ }^{98}$ This interpretation, which coincided with that of Italian progressive media, strictly contrasted with the views of right-wing newspapers which rather

\footnotetext{
${ }^{93}$ Giorgio Cesare, "Gli interessi reciproci fra Italia e Jugoslavia," Trieste (91) (1971).

${ }^{94}$ ACS, Carte Moro, Ministero Affari Esteri 1969-1972, Questioni nazionali e internazionali, Busta 147, "Resoconto segreto Italia-Jugoslavia," February 9, 1971.

${ }^{95}$ ASL, Fondo Democrazia Cristiana, Segreteria Politica Forlani, Corrispondenza con Organizzazioni Varie, Sc.218, fasc.16, "Local DC Trieste to Forlani," March 18, 1971.

${ }^{96}$ AUI, 1967-1987, Busta 23, Folder 6/6/1,Fasc. 5/6, "Albertini to Santin," July 5, 1971.

${ }^{97}$ AUI, 1967-1987, Busta 23, Folder 6/6/1, Fasc.5/6, "Confidential Santin to Albertini," July 9, 1971.

98"Tito on Piazza Venezia," The New York Times (March 27, 1970).
} 
emphasized popular hostility toward Tito and described in great detail the brutality and suffering that the victims of the "foibe" had experienced. Further condemning the meeting, it also labeled the Yugoslav dictator as "a butcher of Italians." 99 Rightist magazines also claimed that Tito's visit was attended by "more policemen than bystanders," a statement that clearly aimed to highlight the general public's apathy and indifference toward the Yugoslav leader. ${ }^{100}$ Moro, eager to minimize parliamentary opposition, therefore removed territorial issues from the agenda of his meeting with Tito and, throughout February and March, publicly stressed Italy's unwillingness to changes in the geo-political status of the border.

Despite these official statements, right-wing groups continued to exploit the fear and anxiety resulting from Trieste's geo-political proximity to Yugoslav Communism. ${ }^{101}$ In Trieste, organizations such as "Ordine Nuovo" (New Order) and "Avanguardia Nazionale" (National Avanguard), for example, intensified their anti-Slav propaganda against the Slovene minority and its institutions. ${ }^{102}$ The previously mentioned discovery of weapons and munitions in the Carso hills as well as the death of police officers who were killed in a terrorist attack by members of "Ordine Nuovo" discredited these organizations of the Italian radical right along with neo-fascist youth groups, such as "Giovane Italia" (Young Italy). ${ }^{103}$ These and other episodes of right-wing political extremism were widely advertised by the local Communist Party in the pamphlet "Il Calendario Nero" (The Black calendar) with the hope of undermining popular support for the neo-Fascist Party in the upcoming national elections. ${ }^{104}$ In Trieste, however, the neo-Fascist Party responded to communist propaganda by distancing itself from extremist formations and centering its campaign

\footnotetext{
99،"Roma ignora Tito: ospite sgradito e ambiguo," Il Secolo d'Italia (March 26, 1971).

${ }^{100}$ Paolo Berti, "Rapporti esemplari," Il Piccolo (March 26, 1971).

101 "Una centrale di provocatori," L'Unità (August 29, 1973).

${ }^{102}$ ACS, MI, Schedario Fascicoli Classificati, Partiti-Movimenti Politici 1971-1975, Faldone 18, Fasc. 195/P/87, MSI Trieste, "Note from Prefect," June 17, 1971.

103،"Agguato con un'auto carica di esplosivo,” Il Popolo (June 2, 1972).

${ }^{104}$ AFG, Fondo Vidali, Fascicolo 71 Trieste Neofascismo a Trieste inchiesta sulle attività di organizzazioni fasciste e parafasciste nel Friuli Venezia Giulia.
} 
on its traditional role in the defense of Italian rights on the ex-zone B, a strategy that gained supporters at this time. ${ }^{105}$

Meanwhile, diplomatic negotiations between Italy and Yugoslavia were slowly proceeding and, looking retrospectively, the Christian Democrats' plans toward the ex-zone B clearly pointed to a forthcoming resolution of the border dispute. For example, Social Democrat Mauro Ferri's statements that it was now time "to recognize the current demarcation line as the frontier between Italy and Yugoslavia" vividly exposed the views of the center-left coalition government in the spring of 1971. From their perspective, in order to end Trieste's economic crisis and the paternalist policy of the central state, it was necessary to resolve all contentious issues with the Yugoslav neighbor. In a city in which approximately 30,000 out of 270,000 people were Slovenes, this goal could be attained only by abandoning the intransigent defense of Italian former claims to the exzone B. ${ }^{106}$

Parties and associations of conservative orientations harshly responded to Ferri's declarations. One such response was from the Istrian Union which sent formal complaints to the leading figures of the central government. ${ }^{107}$ The émigré journal L'Esule (The Exiled) also published an open letter to Ferri in which it stressed the unconvincing nature of his arguments and accused the Social Democrat of secretly plotting with Tito's regime at the expense of the Julian population. ${ }^{108}$ Other Italian newspapers, however, suggested that Ferri's declarations should be read in parallel with West German chancellor Willi Brandt's Ostpolitik, especially its strategy of a quick resolution of border disputes to advance political relaxation with the Socialist bloc. ${ }^{109}$

Ferri's declarations anticipated the upcoming trip of American President Nixon to Belgrade by a few weeks, which further exacerbated the apprehension of the émigrés. Indeed, they feared that

\footnotetext{
${ }^{105}$ Mario Tedeschi, “La destra vince: la DC spalle al muro," Il Borghese (October 31, 1971).

${ }^{106}$ DT, Fondo Coloni, B.6, Folder relazione su Ferri, 1971.

${ }^{107}$ ALN, Folder 1970/I, Segreteria 1971, “Unione degli Istriani,” September 11, 1971.

${ }^{108}$ Paolo Venanzi, “Lettera aperta all'On. Mauro Ferri,” Tribuna Monarchica, October 15, 1971.

109“'Governo e zona B," Il Giornale d'Italia (October 22, 1971).
} 
the American President would pressure both Rome and Belgrade to definitively settle the issue. ${ }^{110}$ Thus, the Istrian Union, which still had the support of approximately 24,000 members, asked Nixon to disregard Tito's territorial goals for the ex-zone B and uphold Italian sovereignty. ${ }^{111}$ The National Italian Irredentist Association also addressed a telegram to President Nixon. ${ }^{12}$ It reported that any territorial concession over the ex-zone B to the Yugoslav Federation, a country affected by socio-political instability, would direct the Yugoslav imperialist gaze toward the Italian border and eventually lead to the communist takeover of the Italian peninsula. ${ }^{113}$ Bartoli instead, more concerned about the Italian minority under Yugoslav authority, called upon the American President to ask Tito about the Italians imprisoned in Yugoslavia as well as the protection of the Italian minority in the ex-zone B. ${ }^{114}$

These letters revealed the deep concerns that local personalities and neo-irredentist associations still harbored toward any compromise over the Istrian region in the early $1970 \mathrm{~s} .{ }^{115}$ Their apprehensions were also shared by the National League, which attempted to win public attention in Trieste by arranging a set of cultural events to celebrate the epic trajectory of Adriatic irredentism. The Communist Party condemned this initiative as an expression of revanchist neoirredentism. In particular, it attacked the central government for providing financial support to the National League which it regarded as a nationalist and reactionary organization that had been highly compromised by Bruno Coceani, whom the communists had often had portrayed as a "Quisling" due to his role as Trieste's Prefect after September 1943. Fully aware of the influential role that the National League played in Triestine politics, the central government responded to these accusations by depicting Coceani as a "respectable figure." 116

\footnotetext{
${ }^{110}$ Valdevit (2004), 114.

${ }^{111}$ AUI, 1967-1987, Busta 23, Folder 6/21, Fasc. 5/21, "Albertini to Nixon," October 29, 1971.

${ }^{112}$ ACS, MI, Dipartimento della Pubblica Sicurezza, Cat.G, Associazioni, 1944-1986, B.363, Folder Unione degli Istriani, "Note from Rome Chief Police," October 31, 1971.

${ }^{113}$ AUS, Fondo Luigi Papo, Busta 5, fasc.50, "Letter from President of ANII to Nixon," 1971.

${ }^{114}$ ASL, Fondo Democrazia Cristiana, Segreteria Politica Forlani, Corrispondenza con gli Organi Periferici, Sc.202, S. fasc.3, "Bartoli to Nixon," October 26, 1971.

${ }^{115}$ Fabio Lonciari, "Davanti ai problemi del confine orientale," L'Italiano (October 10, 1971).

${ }^{116}$ AST, Fondo Coceani, Serie 1, Documenti Personali, "Reponse to Parliamentary Motion from Ministry of Public Education," October 11, 1971.
} 
When considering the Christian Democratic financial support to associations and figures of patriotic and anti-communist sentiments, this affirmation of Coceani was certainly informed by reasons of political opportunism. More than any other post-war personality, Coceani embodied the nationalist ideals of irredentist intellectual Attilio Tamaro. In upholding the idea of Italian territorial sovereignty not only over the ex-zone B but also over Fiume and Dalmatia, Coceani refused to recognize both the anachronism of post-war irredentism as well as the strength of the new Cold War's logic of détente. In such a context of international and domestic political changes, neoirredentist ambitions unavoidably vanished from Italian politics. ${ }^{117}$

\section{Confronting Detente}

After the Venice meeting between Italian Foreign Minister Aldo Moro and Yugoslav Foreign Minister Mirko Tepavac in February 1971, Italian and Yugoslav bilateral relations decisively improved. Later that year representatives of Italian veteran associations also made an official visit to Yugoslavia for the first time ever. During this visit, spokesmen reasserted the inviolability of existing frontiers and the principle of national independence. Led by ex-partisans who had failed to notify the Italian Embassy of their intentions, the visit caused embarrassment and disappointment among leading political personalities as well as the Foreign Service. ${ }^{118}$ Any reference to the inviolability of the borders indeed would have been understood as recognition of Yugoslavia's provisional or definitive sovereignty over the ex-zone B. In the government's view, this unauthorized visit could ultimately disturb the ongoing negotiations over an issue that, regardless of its minimization within national public opinion, remained politically significant in Trieste.

In early 1972, in response to public concern over possible changes of the geo-political status of the ex-zone B, Triestine members of the local Christian Democrats asked Rome to respond to the

\footnotetext{
${ }^{117}$ AUS, Fondo Luigi Papo, Busta 1, fasc.4, "Letter from President of Milan branch to Papo," December 31, 1971.

${ }^{118}$ ACS, PCM, Gabinetto, Affari Generali 1968-1972, Associazione Nazionale Combattenti e Reduci 14=2 28900/2/1, Sottofasc.1, "Letter to President of Council Colombo," November 12, 1971.
} 
rumors. Members of the Ministry of Foreign Affairs replied by stating that, despite friendly relations between Italy and Yugoslavia, both states mutually recognized each other's independence and territorial sovereignty within national borders. Although this response did not specify which Italian and Yugoslav borders were mutually recognized, a subsequent note by the national head of the Christian Democrat Committee for Foreign Policy confirmed the on-going validity of the London Memorandum. ${ }^{119}$

Meanwhile, the Istrian Union identified Fanfani as a champion for the Istrian cause and hoped his appointment as the head of government would block possible secret negotiations over the fate of the Istrian region. ${ }^{120}$ However, despite his public persona, Fanfani had already recognized that Yugoslav sovereignty was indisputable and had privately abandoned the cause. By the early 1970s, the Christian Democrats' commitment to dispute Yugoslavia over of the ex-zone B had also dwindled, not only among its center-left factions but also its most conservative leaders outside Trieste. As Giorgio Tombesi recalls, conservative politicians such as Christian Democrat Giulio Andreotti would say, "You all forgot that we were the losers. Tito was the winner." ${ }^{121}$ This statement, directed at local patriotic rhetoric, reveals a sense of political realism that inevitably undermined irredentist dreams toward the eastern border.

At the time, however, the party's deceptive statements were being positively received by the émigrés whom, while still dreaming of an unlikely return of the ex-zone B to Italy, proved even more concerned about preserving Italian culture inside the Istrian region. Indeed, multiple reports from Italian organizations in Yugoslavia emphasized that the Italian minority was still subjected to discrimination in the fields of education and language as well as in public offices. ${ }^{122}$ These issues were also intertwined with the issue of the citizenship of the Italian residents in the ex-zone B, a problem that had been formally resolved by the Paris Peace Treaty and later confirmed in the

\footnotetext{
${ }^{119}$ DT, Fondo Coloni, B.6, "Letter Bernassola to Tonutti," January 14, 1972.

${ }^{120}$ ACS, MI, Dipartimento della Pubblica Sicurezza, Cat.G, Associazioni, 1944-1986, B.363, Folder Unione degli Istriani, "Confidential Note from CGFVG to PCM," February 20, 1972.

${ }^{121}$ Tombesi's Interview, March 2012.

${ }^{122}$ DT, Fondo Coloni, B.6, Folder Minoranza Italiana, 1972.
} 
London Memorandum. ${ }^{123}$ The Italian border community, which was discouraged by the Italian state's ineffective response to Yugoslav violations, sought support from other institutions, in particular the Popular University of Trieste and the General Consulate of Capodistria.

In the early 1970 s these institutions effectively replaced the Association of Istrian Communities (formerly Istrian CLN) which had witnessed a gradual and steady cut in governmental contributions and only survived with the support of the local Triestine authorities and the Office of Border Zones. While the former provided a financial contribution of three million lira for the 19721973 year, the latter provided extraordinary contributions to the former CLN Istria that were categorized under the broader frame of "expenses for the defense of Italianità" in $1972 .{ }^{124}$ This concession suggests that, in line with the post-1954 strategy toward the border, the central government still considered the preservation of Italian culture in the ex-zone B an important factor in minimizing possible criticism toward its policy of Adriatic detente from the political opposition but especially from the émigré associational network. ${ }^{125}$

A few months after Turin's newspaper La Stampa stated that "Italian and Yugoslav cooperation requires the sacrifice of the zone B," the French right-wing magazine Combat claimed that the Italian government had definitively recognized Yugoslav sovereignty over the ex-zone B. ${ }^{126}$ Indeed, in April 1972 it reported on the secret negotiations in great detail and claimed that the final agreement had been achieved between February 28 and 29 as part of a broader agreement between Italian Social Democrats and German Socialists in support of Brandt's “Ostpolitik." ${ }^{127}$ Foreign Minister Moro reacted to the article by promptly writing to Bartoli and insisting that the claims of

\footnotetext{
${ }^{123}$ The Paris Peace Treaty regulated such an issue for both the territory lost to Yugoslavia and the Free Territory of Trieste. It established that all Italian citizens who were resident in zone A and B of the FTT before June 1940 maintained their Italian citizenship without any need of opting for it and unless decided to renounce to it. AUI, Fondo C.N.C. Busta 7, Folder F/1, "Note to Il Piccolo," April 4, 1972.

${ }^{124}$ UZC, Sezione V, Busta 9, Vol. I, Folder Associazione delle Comunità Istriane già Comitato di Liberazione Nazionale dell'Istria, "PCM Note," April 15, 1972.

${ }^{125}$ ASL, Fondo Democrazia Cristiana, Segreteria Politica Forlani, Corrispondenza con gli Organi Periferici, Sc.205, "Local DC Trieste to Forlani," February 22, 1972.

${ }^{126}$ ALN, Folder 1972/1, Segreteria Generale, “C.N.C. to La Stampa,” April 7, 1972.

${ }^{127}$ ACS, Carte Moro, Ministero Affari Esteri 1969-1972, Questioni nazionali e internazionali, Busta 154, "Telegramma 16665," April 26, 1972.
} 
Combat were completely unfounded. ${ }^{128}$ While admitting that the principles of Brandt's Ostpolitik effectively threatened the judicial status of the ex-zone B, Andreotti also tried to reassure the émigrés. $^{129}$

Throughout 1972 rumors about the ex-zone B were rife and the émigré associations naively sought political reassurance from the central government. ${ }^{130}$ During the summer, for example, the vice-President of the Slovene government claimed that the territorial border with Italy had been definitively set in 1954. The President of the Istrian Union, Sardos Albertini, wrote Prime Minister Andreotti to ask for personal clarifications. ${ }^{131}$ In his letter, Albertini also called for an official declaration from the Italian government, which indeed he received. ${ }^{132}$ In discussing the governments' response, Bartoli expressed his personal appreciation to President Moro for his heartfelt defense of the émigrés' rights. ${ }^{133}$ Although the duplicitous statements of the government temporarily strengthened the émigrés' confidence and trust in the central authorities, they would later arouse popular animosity and anger. More important, the government's claims about the exzone B became statements for public consumption which, in a border city like Trieste, enhanced popular support for the Christian Democrats and their fictitious politics of identity.

Within national public discourse, however, the issue of the ex-zone B was discussed in pragmatic terms and became increasingly connected to the broader process of Adriatic detente. Thus, in an article of Il Corriere della Sera from December 1972, Dino Frescobaldi argued that the "ex-zone B was the right price to pay for a successful and credible Italian Ostpolitik." "134 The Istrian Union responded to Frescobaldi's article by claiming that the preservation of Italian formal rights over the ex-zone B stemmed from recurrent governmental reassurances about Istria's unchanged

\footnotetext{
${ }^{128}$ AST, Fondo Bartoli, Busta 98, Corrispondenza, "Moro to Bartoli," April 28, 1972.

129،Nessun progetto d'accordo è in discussione: una seconda smentita di Roma sulla zona B," Il Piccolo (May 6, 1972).

${ }^{130}$ Right-wing newspapers and magazines published news which reported the existence of secret agreements or the firm response of the neo-fascist party to any attempt to Italian formal sovereignty of the ex-zone B. For instance, see "Trieste tricolore con Almirante per l'Italia contro i cedimenti," Il Secolo d'Italia (April 24, 1972) and "Provata la cessione della zona B: i retroscena dell'accordo," Il Borghese (May 14, 1972).

${ }^{131}$ AUI, Miscellaneous, Folder Corrispondenza con Personalità del Governo 1961-1973, "Albertini to Andreotti," June 7, 1972.

132،“Assicurazioni sulla zona B di Andreotti all’Unione Istriani,” Difesa Adriatica (May 16-27, 1972).

${ }^{133}$ ACS, Carte Moro, Atti Personali 1964-1977, Busta 177, Fasc.21, "Telegram from Bartoli," June 29, 1972.

${ }^{134}$ Dino Frascobaldi, “Italia e Jugoslavia. Un'amicizia da rafforzare," Corriere della Sera (December 1, 1972).
} 
sovereignty and was intended to compensate for the Italian territorial renunciations after 1947 as well as the continuous discrimination against the Italian minority in Yugoslavia.

This conflicting dialectic between émigrés' associations and progressive segments of national public opinion demonstrated the complexity of reconciling Italy's national and international interests. Indeed, in the context of international détente, past irredentist claims became untenable and further divided the neo-irredentist network itself. For example, during the summer of 1972, Renzo Migliorini, a leading member of the National Venetia Julia and Dalmatia Association (ANVGD) harshly criticized other émigré associations for their propaganda and support of Moro's center-left strategy. Migliorini accused these associations of pandering to Moro's policy toward Tito in exchange for financial support from both the central government and Trieste's mayor, the Christian Democrat Marcello Spaccini. This behavior, Migliorini argued, clashed with the desires of the Julian population and weakened Italian claims over the ex-zone B. ${ }^{135}$ Not to be outdone, the neo-fascist Renzo De Vidovich argued that an internal coup in the Triestine branch of the ANVGD had resulted in the appointment of Christian Democrats who leaned toward Fanfani's leadership. Contrary to De Vidovich's arguments, however, the appointment of Paolo Barbi as President of the ANVGD aimed to minimize tension between the most moderate and radical factions of the association. In addition, the gradual reduction of governmental contributions to the ANVGD confirmed that the Christian Democrats only partially trusted its leadership and wished to minimize any resistance to the Adriatic detente. ${ }^{136}$

The political context of détente weakened not only Italy's former irredentist claims but it also aroused Yugoslav expectations for a quick resolution of the disputed border. In December 1972, during his visit to Montenegro, Tito harshly criticized the orthodox views of the Italian émigré associations which openly displayed their unrepentant irredentist nature. In contesting Yugoslav rule over the ex-zone B, Tito continued, the émigrés detrimentally affected the credibility

\footnotetext{
${ }^{135}$ AST, Fondo Bartoli, Busta 64, Zona B, "Letter from Migliorini," July 20, 1972.

${ }^{136}$ ALN, Folder 1973/I, Segreteria 1973, “Colpo di mano fanfaniano nell’ANVGD di Trieste per rompere l'unitá degli esuli: replica dell'On. De Vidovich al Vice Presidente Drago.”
} 
and international reputation of the Italian national government. In one of his last public statements before dying in April 1973, Bartoli promptly responded to Tito. He emphasized the sober political conduct of both émigré and patriotic associations as well as the numerous manifestations of solidarity and appreciation for their cause from both national and international public opinion. In addition, Bartoli argued that Tito's words insulted the memory of the Italian victims of Yugoslav violence and could be interpreted as a sign of renewed Yugoslav rapprochement with the Soviet Union. Bartoli concluded by writing that "when comparing the privileged treatment of the Slovene minority in Trieste to that of the Italian minority in Yugoslavia, the grievances of the Yugoslav dictator appear foolish." 137

The émigré associations responded to Tito's declarations of December 1972 and not only sought political reassurance from both members of the government and the Christian Democrats but also from other conservative parties. In response, Prime Minister Giulio Andreotti confirmed that "the Italian government considered its territorial rights over the ex-zone B indisputable."138 Similarly, Giorgio La Malfa, the Secretary of the Republican Party, confirmed that Foreign Minister Giuseppe Medici would firmly protest against Yugoslav claims. ${ }^{139}$ Furthermore, the central government also decided to publicly protest against the decision of the Yugoslav government to nationalize all of the property of the Italian citizens who had previously left the ex-zone $\mathrm{B}$. This provision indeed clashed with former promises to respect the right of Italain émigrés to the properties that had been abandoned during the exodus. ${ }^{140}$

Thus, throughout 1973, while repeatedly contesting the Yugoslav administration's unilateral violations of the London agreements, the Italian government pursued the amendment of such unfair provisions. ${ }^{141}$ The firmness of the Italian government, however, barely affected Yugoslav legislative

\footnotetext{
${ }^{137}$ AUS, Fondo Luigi Papo, Busta 37, Fasc. Istria Zona B, "Bartoli risponde a Tito," December 30, 1972.

${ }^{138}$ AUI, Miscellaneous, Folder Corrispondenza con Personalità del Governo 1973-1976, "Andreotti to Cobolli," January $17,1973$.

${ }^{139}$ AUI, Fondo C.N.C. Busta 3, Folder C/3, "Medici to La Malfa," January 21, 1973.

${ }^{140}$ AUI, Miscellaneous, Rapporti con i Partiti Politici, fasc.2/6, "La Malfa to Sardos Albertini," February 7, 1973.

${ }^{141}$ AUI, Fondo C.N.C. Busta 3, Folder C/3, "State Undersecretary for Foreign Affairs to Representative De Vidovich," December 28, 1973.
} 
provisions toward the ex-zone B. Indeed, the Republic of Slovenia had come to consider the exzone B as an integral part of its territory. Mail that was sent from Trieste to the ex-zone B and addressed only with the Italian names of the cities was regularly returned. Both parliamentary representatives and émigré associations formally protested and the Italian government, after discussing the issue with the Yugoslav authorities, stated that it was merely a problem of mismanagement. It also added that the bilingual place names had already been agreed upon by the Yugoslav authorities yet, by March 1973, the only names used by the postal service were those in the Slovenian language. ${ }^{142}$

As shown, in the early 1970s, the territorial dispute over the ex-zone B, although minimized in national political discourse, remained a contested issue between the émigrés in Trieste and the Italian state. At the same time and regardless of rhetorical claims of the Italian and Yugoslav frontier as "the most open border in Europe," the Istrian problem continued to plague bilateral relations between Belgrade and Rome. ${ }^{143}$ Within the climate of international relaxation of the $1970 \mathrm{~s}$ any delay in Italy's formal recognition of Yugoslav sovereignty over the ex-zone B could no longer be postponed. Thus, between March 19 and 20, 1973, Yugoslav Foreign Minister Miloš Minic and Italian Foreign Minister Giuseppe Medici met in Dubrovnik, Croatia. ${ }^{144}$ As demonstrated by Italian scholar Massimo Bucarelli, during this meeting the two Foreign Ministers agreed on eighteen points to resolve the border dispute and to continue its secret negotiations which on the Italian side were entrusted to an official of the Ministry of Industry and Commerce Eugenio Carbone and Foreign Economic Relations Committee Chairman Boris Snurdel. ${ }^{145}$

\footnotetext{
${ }^{142}$ AUI, Fondo C.N.C. Busta 7, Folder F/4/2, "De Vidovich to Ministro Poste e Telecomunicazioni," March $14,1973$.

${ }^{143}$ Spazzali (2006), 209-213.

${ }^{144}$ Domenico Sassoli, "In clima di cordialità cominciati i colloqui di Medici a Dubrovnik," Il Popolo (March 20, 1973).

${ }^{145}$ Bucarelli (2008), 68.
} 


\section{The Signage Dispute of 1974: the Last Crisis across the Border}

After the Dubrovnik meeting, the distrust and suspicion of local as well as national neoirredentist associations toward the Italian government exponentially increased. ${ }^{146}$ In May 1973, Giusto Muratti, the President of the National League sent a letter to the President of the Istrian Union Sardos Albertini in which he cited the existence of a confidential document stating that Italy and Yugoslavia had been carrying out secret negotiations for the final territorial settlement of the border. According to this document, the results of the clandestine meetings would be formally announced after the regional elections of $1973 .{ }^{147}$ Muratti also reported that he was informed about this document by a member of the office of Foreign Affairs. Although the letter does not provide any further information about Muratti's informer or any additional details to verify the content of this confidential document, the events of the following months confirmed the behind-the -scenes actions of the Christian Democrats.

After receiving Muratti's letter, Albertini wrote to Minister of Interior Rumor to denounce Moro's assurances to Yugoslavia in Venice in 1971 as well as those of Medici at the meeting in Dubrovnik (which he referenced with the Italian name Ragusa). In his letter, Albertini also accused the Christian Democrats of weakening Italian claims and facilitating the transformation of the demarcation line into the Adriatic frontier. These actions, he argued, not only violated Italy's rights of sovereignty but also threatened Trieste's economy, as they would have extended Yugoslav territorial waters to its port. To prevent such a scenario, Albertini asked Rumor to support the appointment of a personality other than Moro or Medici as Minister of Foreign Affairs: a nonpartisan representative who had not taken part in former talks with the Yugoslav neighbor. ${ }^{148}$ Furthermore, Albertini asked Bishop Santin to "directly approach the national Christian Democratic governing elites and advertise the defense of the Italianess of the Istrian region within the pages of

\footnotetext{
146،La zona B questione fondamentale afferma il Ministro Medici a Ragusa,” Il Piccolo (March 21, 1973).

${ }^{147}$ ALN, Folder 1973/I, Segreteria 1973, "Muratti to Albertini," May 15, 1973.

${ }^{148}$ AUI, Miscellaneous, Folder corrispondenza con personalità del governo 1973-1976, " Sardos Albertini to Rumor," July 3, 1973.
} 
the Catholic magazine Vita Nuova. ${ }^{149}$ As these examples suggest, the émigré network exerted increasing pressure on political and religious figures who over time had proved sympathetic toward the Istrian problem.

Consequently, when Andreotti left office in the summer of 1973, the émigrés perceived the appointment of Rumor as head of the center-left coalition government and, especially, Aldo Moro as Minister of Foreign Affairs as proof of the Christian Democratic intentions to formally settle the issue of the ex-zone B. ${ }^{150}$ In the views of the émigrés, Andreotti had avoided any concession to the Yugoslav government over the Istrian region and, therefore, had often been depicted as a defender of Italian interests on the eastern border. ${ }^{151}$ This view, however, was significantly skewed. The Triestine Christian Democrat Sergio Coloni's private papers show that before the fall of his government, Andreotti had metaphorically signed a "blank check" to concede Yugoslav sovereignty over the ex-zone B. Indeed, during the regional elections of June 1973, Andreotti met with Christian Democrats Belci, Coloni, and Rinaldi whom, with the support of local experts, had prepared a plan for a package deal with Yugoslavia. The plan covered the main issues related to the frontier economy, the territorial borders, the minorities, and the abandoned property. After discussing aspects of the border dispute with the local Christian Democrats, Andreotti approved the plan. ${ }^{152}$ Thus, the year 1973 marked the end of a political process that, beginning in the early 1960s with the support of the most progressive fringes of the Christian Democratic Party, had gradually met the consensus of conservative figures like Andreotti.

At that time, however, Triestine conservatives looked with great confidence to the Christian Democrats who generally identified with Fanfani's leadership and largely distrusted progressive leaders like Moro. After his appointment as Minister of Foreign Affairs, Moro, aware of widespread local opposition, reiterated that all news reporting the on-going negotiations toward a final

\footnotetext{
${ }^{149}$ AUI, 1967-1987, Busta 23, Folder 6/6/1, Fasc, 5/6, "Confidential Albertini to Santin," July 3, 1973.

${ }^{150}$ ALN, Folder 1973/I, Segreteria 1973, “Unione degli Istriani,” July 5, 1973.

${ }^{151}$ AUI, Miscellaneous, Folder corrispondenza con personalità del governo 1973-1976, "Unione Istriani," July 9, 1973.

${ }^{152}$ DT, Fondo Coloni, B.7, Folder politica 1974, "Note of a Global Plan 1974."
} 
settlement between the two governments were not only untrue but also harmful to their diplomatic relations. $^{153}$

Throughout 1973, not only political but also military considerations affected the decisions of the Italian government to quickly end the border dispute. Italian military analysts stressed that Yugoslavia's deep economic crisis had exacerbated phenomena of local ethno-nationalism and, while undermining its domestic stability, also threatened Italian security. In envisioning a post-Tito Yugoslavia, the 1973 report of the Italian intelligence agency (Defense Information Service, SID) emphasized the possibility of an intervention in Yugoslavia by the Soviet Union. Despite the positive status of Italian and Yugoslav diplomatic relations, military analysts concluded, "a local conflict between the Adriatic neighbors remained a possible scenario." 154 Thus, the report confirmed that the Italian government could simultaneously strengthen its security and Yugoslav stability by recognizing the territorial provisions of the London Memorandum as a definitive solution and establishing the Italian southeastern border along the demarcation line.

Political and military factors, therefore, played an especially important role in the acceleration of the final settlement of the Adriatic border yet it still required an external catalyst. In the summer of 1973, the Conference on Security and Cooperation in Europe (hereafter CSCE) provided the ideal context within which the Italian government could legitimize the recognition of Yugoslav sovereignty over the ex-zone B as both a consequence of the unchangeable nature of Europe's post-war borders and an example of Italy's major contribution to international peace. ${ }^{155}$

While the Italian government saw the climate of international relaxation between opposing blocs as a unique opportunity to advance Adriatic friendship, the National Center for the Coordination of the Defense of Zone B and Istria (C.N.C.) understood it as an impending threat which expedited the formal annexation of the Istrian region by Yugoslavia. ${ }^{156}$ In an attempt to gain

\footnotetext{
${ }^{153}$ S.D.’Il preciso impegno del governo circa i nostri diritti sulla zona B," Difesa Adriatica (October15-30, 1973).

${ }^{154}$ ASM, Ufficio Operativo, Folder I-5, Raccoglitore 32, Secret "La difesa della frontiera nord-orientale," 1973.

${ }^{155}$ Garzia (2011), 104.

${ }^{156}$ ACS, MI, Dipartimento della Pubblica Sicurezza, Cat.G, Associazioni, 1944-1986, B.363, Folder Unione degli

Istriani, "Letter from Sardos Albertini to CGFVG and PCM," August 2, 1973.
} 
popular support, the C.N.C. conducted a public campaign whose ultimate goal was to draw national and international public attention to the problem of the ex-zone B and its émigrés. Its campaign was particularly successful in Australia, a continent that had experienced mass immigration from the city and its surrounding territory during the post-war years. ${ }^{157}$ Julian émigrés who had permanently settled in Australia, United States, or South America, indeed, continued to support the Italian claims to their native Istria by occasionally making financial contributions to the émigré associational network. $^{158}$

At the same time, however, major international consensus toward the Helsinki principle of the inviolability of the frontiers and Moro's strategy of including the Italian Communist Party within the center-left coalition government created a growing sense of powerless among the émigrés. Disillusionment and discouragement also pervaded the most intransigent fringes of the neo-irredentist movement. Istrian war veterans like Giorgio Cobolli, who received the WWII gold medal of military service, argued that, although he personally believed in the need to carry on the defense of Italian claims to Istria, the prolonged silence of the national government on the issue "represented a clear sign of the defeatist attitudes of the current political class."159

Likewise, the correspondence between the C.N.C. and the Istrian Union confirmed that the national government was perceived, especially among the few Italians residents of the ex-zone B, to have come to terms with Tito. Nonetheless, phrases such as "Down with Tito" or "We are Triestines not Slavs" could still occasionally be found on the walls of cities in the ex-zone B along the demarcation line such as Buie. ${ }^{160}$ These demonstrations of a continued Italian existence in Istria were widely praised by the émigrés, patriotic, and right-wing press and were taken very seriously by the Yugoslav administration. In reading such graffiti as symptoms of Fascism on the border, the Yugoslav authorities mistakenly believed that an Italian center-right government in Rome would

\footnotetext{
${ }^{157}$ AUI, Fondo C.N.C. Busta 5, Folder D/20/4, "C.N.C. to Director of local newspaper Il Globo," September 5, 1973.

${ }^{158}$ AUI, Fondo C.N.C. Busta 5, Folder D/20/5, "Benedetti to Albertini," October 3, 1973.

${ }^{159}$ AUI, Miscellaneous, Folder corrispondenza con personalità del governo 1961-1973, "Cobolli to Sardos Albertini," December 1, 1973.

${ }^{160}$ AUI, Fondo C.N.C. Busta 8, Folder G/2, "Varie 1972-1973."
} 
have a better chance at settling the issue of the zone B rather than a center-left government; the latter it believed would require at least an additional ten years. ${ }^{161}$

As this statement suggests, the Yugoslav authorities were aware of the complexity of the issue as well as Trieste's hostility to any change in the judicial status quo of the ex-zone B. Despite this and within the favorable context of the Helsinki talks, Yugoslavia publicized its intentions to definitively close the border dispute. Thus, in January 1974, the Yugoslav government erected signs approximately thirty meters from the demarcation line that stated "S.F.R Jugoslavija-S.R.

Slovenija." ${ }^{162}$ Upon learning of the decision, the C.N.C. sent a note of formal protest to both the CSCE and leading personalities of the Italian government, among them Christian Democrats Rumor, Moro, and Fanfani. In its message, the C.N.C. stressed that "Yugoslav annexationist ambitions violated the spirit of the London Memorandum and contradicted the Helsinki principles that underscored contemporary European territorial agreements." ${ }^{163}$ The claims of the C.N.C. were interestingly supported by a Serbian committee of popular defense which, criticizing Yugoslav communism for the steady repression and discrimination toward the Italian minority of the ex-zone B and Dalmatia, drew a parallel between Italian and Serbian resistance to Yugoslav assimilation policies. $^{164}$

Both in February and March the Italian government sent two notes of formal protest to Belgrade in which it stressed that Yugoslav sovereignty had never extended over the ex-zone B. ${ }^{165}$ Condemning the fascist and irredentist tones of the Italian complaints, the Yugoslav government unsuccessfully requested that the Italian government withdraw them. On March 15, 1974, the Yugoslav authorities sent a new letter in which it reiterated that the London Memorandum sanctioned the partition of the former Free Territory of Trieste and therefore recognized Yugoslav

\footnotetext{
${ }^{161}$ ACS, Carte Moro, Ministero Affari Esteri 1973-1974, Busta 162, Jugoslavia questione territoriale, "Macotta to Moro," September 14, 1973.

${ }^{162}$ ACS, Carte Moro, Ministero Affari Esteri 1973-1974, Busta 162, Jugoslavia questione territoriale, "Secret report to Moro," February 3, 1974.

${ }^{163}$ AUI, Fondo C.N.C. Busta 7, Folder F/3/1, "C.N.C. to Fanfani," January 25, 1974.

${ }^{164}$ Translated note coming from "Srpska narodna Odbrana" Odbor o2. AUI, Fondo C.N.C. Busta 7, Folder F/3/1, "Difesa popolo serbo Comitato O2," February, 1974.

165، Aspra risposta a una nota della Farnesina: definitive per Belgrado le frontiere con l'Italia,” Il Piccolo (March 17, 1974).
} 
territorial sovereignty over the zone B. From a Yugoslav perspective, "if the territorial status of the zone B had to be questioned, the same had to be done for Trieste."166

Although the London Memorandum did not invalidate Italy's formal territorial sovereignty over the ex-zone B, external observers believed that the Italian position was strongly influenced by national irredentist circles. ${ }^{167}$ Years of Italian and Yugoslav rule over the two halves of the former FTT indeed made any revisionist proposal untenable for both governments. At the same time, however, revisionist statements still evoked popular responses on both sides of the border, further confirming the strength of a politics of identity inside Trieste and its territory. Indeed, in an article entitled "Disdain and Perplexities among the Adriatic Émigrés," the C.N.C. labeled the protest of 10,000 Slovenes in Capodistria and their anti-Italian slogans as clear expressions of Yugoslav annexationist ambitions and called for a firm response from the Italian government. Italian national and local newspapers also highlighted the illegitimacy of Tito's claims and condemned the aggressive expressions of anti-Italian sentiments that had transpired from the Slovenian demonstration.

On March 24, 1974, the Yugoslav government undertook military exercises and mobilized its forces along the demarcation line. While this move provoked the harsh criticism of conservative elements of Italian public opinion, progressive newspapers such as Il Corriere della Sera depicted the exercises as a clear sign of rising Yugoslav fears of Soviet threats to its territorial integrity. In definitively recognizing Yugoslav sovereignty over the ex-zone B, the newspapers suggested, the Italian government would ultimately consolidate international peace, an argument that had been repeatedly advanced by the Christian Democrats and its center-left coalition government. ${ }^{168}$

While already coping with mounting local criticism for its weak response to Belgrade's aggressiveness, Rome was also harshly criticized by the émigré associations for its decision to first suspend in early 1974 and then, in the summer, restore its contributions to the Italian associations in

\footnotetext{
${ }^{166}$ ACS, Carte Moro, Ministero Affari Esteri 1973-1974, Busta 162, Jugoslavia questione territoriale, "Note from Belgrade," March 30, 1974.

${ }^{167}$ Chino Alessi, "Zona B: la vertenza rimbalza alla conferenza europea di Ginevra,” Il Piccolo (March 23, 1974).

${ }^{168}$ FBIS (March 28, 1974).
} 
the ex-zone B. As discussed above, governmental contributions had indeed been drastically reduced from L.5.000.000 in early 1971 to L. 1.700 .000 in $1974 .{ }^{169}$ In local views, these measures stood in stark contrast to the state's financial contributions to the Slovene minority in Trieste. By March 1974, Slovene associations had experienced an impressive increase in state support from about five to one hundred million lira in state contributions. Between 1963 and 1973, the regional government had also exponentially increased its support, from 2 to 85 million lira. Among the émigrés, economic support for the Slovene minority was therefore largely understood as symptomatic of the government's intentions to finally resolve the border dispute. ${ }^{170}$

External observers, however, hardly believed in a quick end to this dispute. While closely following the events, for example, American Intelligence (C.I.A.) reports predicted that the current dispute over the zone B would "probably continue to be noisy and sharply worded" and that Tito wouldn't compromise in fear that it would "encourage other neighbors to raise similar irredentist claims." ${ }^{171}$ Indeed, the report stated, members of the Yugoslav Ministry of Foreign Affairs would be willing to publicly reveal information about the secret talks that could embarrass the Italian government. Tito, the report concluded, would also publicly use NATO military training in the Adriatic as a threat to Yugoslav security and provoke an outburst of domestic nationalism which would further postpone a definitive settlement over the ex-zone B. ${ }^{172}$

The Yugoslav sign controversy and military exercises had certainly drawn national and international attention toward the border dispute between Italy and Yugoslavia. ${ }^{173}$ Both the C.I.A. and the Italian Foreign Ministry agreed that the unyielding behavior of the Yugoslav authorities was ultimately motivated by the belief that the border dispute was part of a Soviet plan aiming to further

\footnotetext{
${ }^{169}$ UZC, Sezione V, Busta 9, Vol.I, Folder Associazione delle Comunità Istriane già Comitato di Liberazione Nazionale dell'Istria, "PCM Note," August 3, 1974.

${ }^{170}$ ACS, MI, Dipartimento della Pubblica Sicurezza, Cat. G, Associazioni 1944-1986, B.340, Folder Minoranza

Slovena, "Confidential from Commissariat FVG to PCM," March 21, 1974.

${ }^{171}$ NARA, CREST, Central Intelligence Bulletin, Yugoslavia-Italy, March 22, 1974.

${ }^{172}$ NARA, CREST, Central Intelligence Bulletin, Yugoslavia-Italy, March 26, 1974.

${ }^{173}$ ACS, Carte Moro, Ministero Affari Esteri 1973-1974, Busta 163, Jugoslavia questione territoriale, "Incoming Secret Telegrams," March-April, 1974.
} 
destabilize Tito's regime and facilitate its overthrow. ${ }^{174}$ The Yugoslav press had effectively criticized the Soviet Union for its lack of support of Tito during the border dispute with Italy and had harshly criticized Western anti-Yugoslav propaganda. ${ }^{175}$ As in the past, the Yugoslav behavior exposed a sense of endangerment and self-encirclement that was strongly informed by the regime's views of the external world. Although Italian and Yugoslav governing elites had rhetorically portrayed the Triestine territory as the "most open border" of Europe, mutual political distrust remained regrettably strong along the frontier. ${ }^{176}$

In April 1974, Tito's speech in Sarajevo decisively reiterated former accusations against the imperialist intentions of the Italian government and its Atlantic allies toward the Yugoslav Federation. ${ }^{177}$ These statements were further echoed by the Yugoslav press which reinvigorated the strong campaign against the supposedly revanchist and proto-fascist fringes of the Italian government, which were unwilling to renounce Italy’s territorial claims. ${ }^{178}$ These declarations provoked the harsh response of the Istrian Union which, in its correspondence with leading members of the government, claimed the "illegitimate nature of the Yugoslav occupation of the exzone B and called for a future plebiscite under the protection of the UN." $" 179$

In response, Andreotti, now Minister of Defense, claimed that the "Italian government would irrepressibly defend Italian national rights." ${ }^{180}$ Differently from former occasions, however, his letter did not firmly reassert Italian sovereignty over the ex-zone B, a detail that was hardly noticeable yet exposed his compromising attitude toward Tito's requests. Meanwhile, the C.N.C. enthusiastically praised the initiative of a few Christian Democrats whose parliamentary request for

\footnotetext{
${ }^{174}$ ACS, Carte Moro, Ministero Affari Esteri 1973-1974, Busta 163, Jugoslavia questione territoriale, "Secret Telegram 14709," March 26, 1974.

${ }^{175}$ NARA, CREST, Central Intelligence Bulletin, Belgrade-Rome Dispute, April 3, 1974.

176،"L'amicizia dei ricattatori," Il Secolo d'Italia (April 2, 1974).

${ }^{177}$ ACS, Carte Moro, Ministero Affari Esteri 1973-1974, Busta 162, Jugoslavia questione territoriale, "Tito's speech in Sarajevo," April 15, 1974.

${ }^{178}$ ACS, Carte Moro, Ministero Affari Esteri 1973-1974, Busta 163, Jugoslavia Questione Territoriale, "Telegram 20262," April 24, 1974.

${ }^{179}$ AUI, Miscellaneous, Folder Corrispondenza con Personalità del Governo 1973-1976, "Cobolli to Andreotti," April 22, 1974.

${ }^{180}$ AUI, Miscellaneous, Folder Corrispondenza con Personalità del Governo 1973-1976, "Andreotti to Cobolli," April, 1974.
} 
the firm defense of the London Memorandum was rhetorically portrayed as an appeal to end the Yugoslav occupation of the Istrian region. ${ }^{181}$ Consequently, Moro's response, which reiterated Italian commitment to fully apply the Memorandum's clauses, boosted the expectations of the neoirredentist movement.

Meanwhile, Tito again proclaimed Yugoslav sovereignty over the Istrian region during the Tenth Congress of the Yugoslav Communist Party. Tito argued that, at a moment in which the unchangeable nature of Europe's post-war borders had become the hallmark of both the Conference on Security and Cooperation in Europe and a blueprint for international peace, Italian territorial claims were merely distortions. Tito's position was generally shared by the heads of the different Yugoslav regional communist parties which additionally emphasized that, under Allied pressure, “the Yugoslav regime had already paid for international peace by renouncing Trieste after $1945 . " 182$

Thus, the views of Rome and Belgrade appeared irreconcilable. Although the executive committees of the émigré associations continued to look with confidence to the central government, a sense of anxiety and disillusionment pervaded its popular base. In a letter to the Istrian Union, an ex-Army officer wrote that "for thirty years the democratic and corrupted national elites have shown a defeatist and subservient attitude toward Tito."183 This behavior, the letter continued, had sanctioned the death of national patriotism and produced nationwide apathy and indifference toward the fate of the Istrian region. While the national government had paid considerable attention to international issues such as Vietnam, Chile, Greece, or Spain, the issue of the ex-zone B had been forgotten. Thus, he concluded, the émigré association should resort to political violence and terror, imitating extremist groups such as Fedayeen in Palestine, South-Tyrol irredentists, and the IRA.

The majority of patriotic and émigré associations members, however, were increasingly suspicious of political extremism and entrusted the defense of the ex-zone B to the Christian Democrats. Trieste itself had expressed its opposition to any renunciation over the ex-zone B firmly

\footnotetext{
${ }^{181}$ AUI, Fondo C.N.C. Busta 3, Folder C/3, "Note from C.N.C.," May 14, 1974.

${ }^{182}$ AUI, Fondo C.N.C. Busta 7, Folder F/3/1,"Tito's speech at X Congress Communist League," May 27, 1974.

${ }^{183}$ AUI, Fondo C.N.C. Busta 7, Folder F/3/1, "Letter from ex-officer to Unione Istriani," April 23, 1974.
} 
yet civilly. ${ }^{184}$ While political right-wing formations had traditionally embraced the radical revision of the Paris Peace Treaty and the reincorporation of Istria, Dalmatia, and Fiume within national borders, the right-wing of the Christian Democrats had, over time, simply espoused the maintenance of the status quo as "an act of justice toward the Istrian community.",185

In addition, by the early 1970s generational change had significantly reduced both the strength and popularity of intransigent views among the émigrés. ${ }^{186}$ In 1966, for example, émigré associations in Fiume counted approximately 13,000 members and monthly distributed 6,000 copies of the journal La Voce di Fiume (The Fiume Voice) whereas by 1974 its membership and distribution had dropped to a few thousand. ${ }^{187}$ Moreover, since the first experiment of the center-left government in 1963, mutual suspicions and latent tensions had weakened the cohesion of the neoirredentist associational network. Indeed, after its moderate turn in the early 1970s, the ANVGD had been often accused of misrepresenting the views of the Adriatic community and working toward a compromise on the ex-zone B. ${ }^{188}$

In retrospect, neo-irredentist protests only impeded a quick resolution to the border dispute in 1974. Although significant key elements of the Triestine population and moderate fringes of the neo-irredentist movement increasingly understood the anachronistic nature of their struggle, they refused to comply with the logic of detente and accept the formal recognition of Yugoslav sovereignty over the ex-zone B. For Italians outside Trieste, however, the London Memorandum of 1954 had ended the border dispute with Yugoslavia and its sovereignty over the ex-zone B could be hardly disputed. These views had been greatly promoted by the most progressive fringes of the Christian Democrats, who, at the same time, wished to remove any sign of diplomatic tension with Tito's regime, consolidate the Adriatic friendship, contribute to the process of international political

\footnotetext{
${ }^{184}$ R.M., "Il volto del nuovo irredentismo," Difesa Adriatica (October 28-November 11, 1972).

${ }^{185}$ AST, Fondo Tombesi, Busta 18, "Speech at Duino-Aurisina", April 22, 1974.

${ }^{186}$ AUS, Fondo Luigi Papo, Busta 5, fasc.47, "Ritagli stampa sul Trattato di Osimo", November 25, 1974.

${ }^{187}$ ACS, MI, Dipartimento della Pubblica Sicurezza, Cat. G, Associazioni 1944-1986, B.292, Folder Libero Comune di Fiume in Esilio,"Confidential Note from Prefect of Padua," June 20, 1974.

${ }^{188}$ ALN, Folder 1974, Segreteria 1974, "Unione degli Istriani, Italia Centro Meridionale," July 16, 1974.
} 
relaxation between blocs, and accelerate the inclusion of the Italian Communist Party while minimizing its local political cost. ${ }^{189}$

\section{And then, Osimo...}

“Tito's regime did the foibe and forced the émigrés to flee from the Istrian region." ${ }^{190}$ With these words, Triestine Christian Democratic Giorgio Tombesi bluntly explained Trieste's opposition to the Osimo Treaty. According to Tombesi, this agreement, whose ambiguous economic benefits became a bone of contention between the city and the Christian Democratic-led government in Rome, certainly sanctioned the postwar borders between Italy and Yugoslavia; at the same time, however, it morally offended majority opinion in the city and eliminated residual hope for the return of the ex-zone B.

As discussed above, the making of the Osimo Treaty significantly accelerated in the early 1970s, especially after the Dubrovnik meeting of 1973. Bucarelli argues that, following the sign dispute and under the pressure of American Secretary Kissinger, Italian and Yugoslav diplomats entered the final stage of their secret diplomatic negotiations for official Italian recognition of Yugoslav sovereignty over the ex-zone B in the last few months of $1974 .{ }^{191}$ At this time, the Italian Ambassador to Belgrade Walter Maccotta sent an interesting telegram to the Director of Political Affairs in the Foreign Ministry Roberto Ducci in which he stated that Italian national public opinion would look positively at the end of the border dispute. Maccotta also added that "Yugoslav concerns toward Fanfani's former statements in support of Italian sovereignty of the ex-zone B were completely unfounded." 192 Indeed, the secrecy and good standing of the negotiations made any external interference from Italian opponents to a final territorial settlement highly unlikely.

\footnotetext{
${ }^{189}$ Sergio Romano, Guida alla politica estera italiana (Milano: Rizzoli, 2002), 199-201.

${ }^{190}$ Tombesi's Interview, September, 2012.

${ }^{191}$ Bucarelli (2008), 70.

${ }^{192}$ ACS, Carte Moro, Ministero Affari Esteri 1973-1974, Busta 162, Jugoslavia questione territoriale, "Secret Notes from Ambassador Macotta," October 16 and October 31, 1974.
} 
In his personal notes from 1975, Sergio Coloni also anticipated a significant change within Triestine local public opinion and stated that "people's political orientations in Trieste were gradually shifting from a traditional Christian Democrat to a Socialist and Communist majority.",193 The local Christian Democrats, therefore, now needed to undertake an increasingly vigorous shift to the left, in line with the sharp turn that national politics had experienced throughout the 1960s. For Trieste, this shift meant the government's abandonment of the defense of the provisional status of the demarcation line and recognition of its permanent character. However, Coloni noted, this step was greatly complicated by the large presence of the émigrés, who were unwilling to passively witness the end of an Italian Istria.

Despite the émigrés' wishes, this process appeared inevitable. As outlined above, even the most conservative factions of the Christian Democrats had agreed to settle the border dispute to prevent, among other factors, threats to Italy's eastern border such as a possible implosion of the Yugoslav Federation. ${ }^{194}$ Concerns for post-Tito Yugoslavia were indeed widespread within the Italian establishment. For example, in their reports of 1975, military analysts reiterated the potentially dangerous effects of Tito's death and foresaw a possible Yugoslav return within the Soviet sphere. ${ }^{195}$ Interestingly enough, in a letter to Communist secretary Enrico Berlinguer, local communist leader VittorioVidali drew the party's attention to Yugoslavia's rising internal instability. Vidali reported that Tito, facing a chronic domestic economic crisis, was conducting a new anti-Cominformist campaign to silence political opposition. In addition, Vidali added, mounting Bulgarian and Greek threats to Yugoslav sovereignty and territorial integrity had strengthened the nationalist orientation of the Slovenian Communist Party in Ljubljana and, consequentially, that of the Slovene minority inside Trieste. ${ }^{196}$

\footnotetext{
${ }^{193}$ DT, Fondo Coloni, B.7, Folder politica 1975, "Notes from Coloni."

${ }^{194}$ Walter Maccotta, "Osimo visto da Belgrado," Rivista di Studi Politici Internazionali 1 (1993): 45-54.

${ }^{195}$ ASM, Ufficio Operativo, Folder I-5, Raccoglitore 32, Secret "La difesa della frontiera nord-orientale," 1975.

${ }^{196}$ In a note to Berlinguer, Vidali criticized the nationalist tones of the Slovenian Communist Party which condemned the political discrimination to which the Slovene minority became object from both Christian Democrats and Triestine communists. AFG, Fondo Apc, RP, MF0204, p.324, "Vidali to Berlinguer," February 18, 1975.
} 
Thus, during its 1975 regional convention, the Triestine Communist Party claimed that "the national government needed to settle the border issue definitively by formally recognizing the status quo" and by aleviating Yugoslav apprehension about its territorial integrity. ${ }^{197}$ More important, its spokesmen implicitly suggested that any further delay in settling the issue could discredit Italy's international reputation and interfere with the historical compromise between Communists and Christian Democrats in national politics. ${ }^{198}$ In his unfinished manuscript on Osimo, Tombesi confirmed that, in his last meeting with Christian Democratic parliamentary groups of February 28, 1978, Moro confirmed that the definitive renunciation to Italian formal rights over the ex-zone B was dictated by the necessity to safeguard the prospective inclusion of the Communist party in a governing coalition. ${ }^{199}$

As these examples show, the national government, under both international and domestic pressure, could no longer postpone the final resolution of the border dispute any longer. Although the émigré community strongly opposed any change to the geo-political status of the ex-zone B, it appears that Triestines were more likely to tolerate the renunciation of the ex-zone B if it brought significant economic compensation. A positive trade-off between territorial renunciation and economic gains could indeed minimize Trieste's emotional response to the definitive lost of the exzone B.

The Italian government, however, had continually denied the existence of any negotiations over the ex-zone B and had never publicly revealed its economic aspect; rather, rumors of secret negotiations had significantly strained relations between the neo-irredentist network and the central government. ${ }^{200}$ Thus, any initiative aiming to enhance Italian and Slovene cooperation was perceived by local irredentists as a threat to Trieste's Italian identity. For instance, in February 1975, the creation of an Italian-Yugoslav association that aimed to intensify cultural relations

\footnotetext{
${ }^{197}$ AFG, Fondo Apc, RP, MF0210, p.0777, “Livi to Berlinguer,” November 15, 1975.

${ }^{198}$ ACS, MI, Schedario Fascicoli classificati, partiti-movimenti politici 1971-1975, Faldone 3, Fasc. 160.P.187, PCI

Trieste, "Report from Local Prefect," March 7, 1975.

${ }^{199}$ Tombesi, Unpublished Manuscript (2006).

${ }^{200}$ IRSML, 340-351.
} 
between the Adriatic neighbors was believed to facilitate Yugoslav plans to annihilate the Italian culture inside the Istrian region. ${ }^{201}$ Such arguments were advertised by the right-wing press and were shared by local nationalists whose numbers had steadily increased also inside the National League. Even though its leadership remained overwhelmingly Christian Democratic, the National League also refused to abide by party policy and endorse the renunciation of the ex-zone $\mathrm{B} .^{202}$ Local resistance against Osimo, however, proved futile. In the summer of 1975, the Vatican's decision to separate the dioceses of Trieste and Capodistria marked a first step toward the official recognition of Yugoslav sovereignty of the ex-zone B. ${ }^{203}$ In addition, the signing of the Helsinki Final Act and the resignation of an Italian member of the Mixed Yugoslav-Italian Committee over personal differences with the foreign policy of Moro's government, also signaled the coming of Osimo. ${ }^{204}$ In such a context, the reconstruction of the C.N.C., which had been disbanded in 1974, represented a last desperate attempt to save the ex-zone B. ${ }^{205}$ For their part, the émigré associations, perhaps aware of the weakness of neo-irredentist arguments, increasingly stressed the unbearable economic damage that the Italian recognition of the border would have on the Triestine economy. ${ }^{206}$

A few days before its announcement in the national Parliament, the Triestine newspaper $I l$ Piccolo, labeled the imminent Italian-Yugoslav agreement as a "lie lasting for twenty long years," and described what Moro would later explain as a decision that was "dictated by reasons of state above any emotional consideration" in detail. ${ }^{207}$ The communist press, for its part, welcomed the prospective resolution of the Adriatic dispute which abided by the Helsinki principle and removed a visible legacy of the fascist war. ${ }^{208}$ Inside the Parliament, however, right-wing representatives

\footnotetext{
${ }^{201}$ ACS, MI, Dipartimento della Pubblica Sicurezza, Cat. G, Associazioni 1944-1986, B.293, Folder Associazione ItaliaJugoslavia, "Report from Chief of Police," February 3, 1975.

${ }^{202}$ ACS, MI, Dipartimento della Pubblica Sicurezza, Cat. G, Associazioni 1944-1986, B.338, Folder Lega Nazionale, "Letter to Ministry of Interior Gui," April 11, 1975.

203،'L’Unità, la zona B, e i comunicati della S. Sede,” Difesa Adriatica (August 1, 1975).

${ }^{204}$ Luigi Romersa, “Come si è giunti a rinunciare alla zona B," Il Giornale d'Italia (September 25, 1975).

${ }^{205}$ Baroni, 670-675.

${ }^{206}$ UI, 1967-1987, Busta 21, Folder 5/55, "Movimento Giovanile dell’Unione degli Istriani," September 25, 1975.

${ }^{207}$ Chino Alessi, “Il governo Moro-La Malfa rinuncia agli ultimi diritti sull'Istria italiana," Il Piccolo (October 2, 1975).

${ }^{208}$ “Il governo espone lo stato delle trattative con la Jugoslavia per l'intesa sui confini," L'Unità (October 2, 1975).
} 
accused the government of severing the historical borders of the nation. Meanwhile, groups of neofascists gathered outside the residence of the President of the Republic to chant "Tito's executioner." 209 These symbolic protests, however, were small in size and went generally ignored within national public discourse.

In a speech on October 4, 1975, Foreign Minister Mariano Rumor presented the Osimo Treaty as an opportunity to restore Trieste's traditional role as a crossroads between people and cultures. ${ }^{210}$ Although Rumor claimed that the Treaty with Yugoslavia was "painful yet unavoidable," he stated that Osimo had facilitated the definitive return of Trieste to Italy, had included a favorable border adjustment and had ended any residual issues with Yugoslavia. ${ }^{211}$ The Treaty also opened the door to new agreements on the creation of a free trade zone, a more efficient use of Adriatic resources, and an improvement in the mobility of people and goods throughout the border region. $^{212}$

International public opinion, while praising Italy for making a great sacrifice to consolidate Yugoslav geo-political stability, presented the agreement as "a worthy example of genuine statesmanship to resolve international problems with patience, goodwill, and a pinch of political courage." 213 The leftist press welcomed the agreement as "a proof of political realism which healed a wound of the fascist war, advanced security and cooperation in Europe, and weakened the petty nationalism of right-wing propaganda." ${ }^{214}$ By contrast, the Italian right vehemently attacked the Treaty which was depicted as the outcome of American and Soviet pressure on the Italian government. ${ }^{215}$ Neo-fascist representatives echoed these arguments and during the parliamentary

\footnotetext{
209"I combattenti a Leone delitto di lesa patria," Il Secolo d'Italia (Ocotber 1, 1975).

${ }^{210}$ Alfredo Orlando, "Ridare all'area di Trieste una funzione europea," Il Popolo (October 4, 1975).

${ }^{211}$ FBIS (October 4, 1975).

${ }^{212}$ For a detailed description of the terms of the Osimo Treaties see Manlio Udina, Gli accordi di Osimo: lineamenti introduttivi e testi annotati (Trieste: Edizioni Lint, 1979).

213“"Trieste as a Symbol," The New York Times (October 9, 1975).

214“"L'accordo definitivo sulla zona B," Rinascita (October 10, 1975).

${ }^{215}$ Trestelle, "Giro del mondo: zona B," L'Italiano (October 9, 1975).
} 
debate labeled Osimo as "an ignominy that was used to remove a bureaucratic burden from Moro's agenda." 216

Whereas the London agreements of 1954 had boosted popular enthusiasm both inside and outside Trieste, Osimo went almost unnoticed in national public opinion. ${ }^{217}$ In Trieste, however, the Treaty was received with a mix of anger and resignation from the émigré associations which portrayed it as a "dirty business." 218 They also took part in symbolic actions that were filled with nationalist rhetoric. In one such instance, disgruntled irredentists like Prince Hardouin, who had been inspired by D'Annunzio's flight over Vienna of 1918, flew over the ex-zone B to distribute leaflets that claimed the "Italianissima" nature of the Istrian region. ${ }^{219}$ Meanwhile, Father Flaminio Rocchi, the spiritual leader of the émigrés, wrote a pamphlet that harshly attacked the secrecy of the negotiations and the content of the agreement. Rocchi highlighted Osimo's violations of international law, recalled the drama of the "foibe" and the Istrian exodus, exposed the contrasting views of different national political parties, and concluded that the "only zone B that was known in Italy was in the soccer."220 This last statement aptly summarizes the atmosphere of apathy and indifference that encompassed the issue outside Trieste. ${ }^{221}$

Above all, the Osimo Treaty led to political consequences that were neither unpredictable nor unexpected and fostered an upsurge in political localism. ${ }^{222}$ Indeed, the Triestine city council experienced a significant fragmentation among the parties of the governmental coalition whose irreconcilable views on the nature and terms of Osimo later led to the emergence of the "Lista per Trieste" (List for Trieste, LPT). ${ }^{223}$ During the political debate inside the Triestine municipal council, Christian Democratic mayor Marcello Spaccini presented the Italian-Yugoslav agreement as the continuation of the historical and political compromise that began with the London

\footnotetext{
216“"Zona B: la Caporetto del compromesso storico,” Il Secolo d'Italia (October 5, 1975).

${ }^{217}$ For a detailed overview of the reaction of national public opinion to Osimo see Valentina Picariello, Politica estera e opinione pubblica. Il Trattato di Osimo (M.A. Thesis, University of Milan, 1996).

218“'L'Italia ha ceduto la zona B," Difesa Adriatica (September 24, 1975).

219،"Zona B: anche dal cielo un'invocazione all'Italianità," Il Secolo (October 10, 1975).

${ }^{220}$ Padre Flaminio Rocchi, L'Accordo di Osimo sulla zona B (Roma: ANVGD, 1976), 19.

${ }^{221}$ “Non è perduta la causa della zona B," Il Secolo d'Italia (October 10, 1975).

${ }^{222}$ Ara and Magris (2007), 181-186.

${ }^{223}$ See Manlio Cecovini, Trieste ribelle. La lista del melone. Un insegnamento da meditare (Milano: Sugarco, 1985).
} 
Memorandum of 1954. Furthermore, he stated, this agreement was the result of the foolishness of the fascist war, the true cause of the loss of Istria.

Spaccini's speech well summarized the main arguments of the political forces that supported Osimo and identified with the center-left coalition. According to Spaccini, Osimo definitively reasserted Italian sovereignty over Trieste and reinforced the long-standing friendship of the Adriatic populations. While strengthening Yugoslav security and defense against Soviet Communism, Spaccini added that the agreement also restored Trieste's traditional role as a city of "indisputable Italian culture and sentiments but with a European vocation." ${ }^{224}$ In addition, Osimo formalized Yugoslav sovereignty which had been informally granted twenty-one years earlier and finally eradicated any possible future tensions over Trieste.

On the other hand, right-wing political parties attributed the post-war configuration of the border to the fallacious behavior of the national resistance and the cowardly actions of the national government that had signed the Paris Peace Treaty of 1947. Thereafter, rightist representatives argued, the FTT immediately became unfeasible and the London Memorandum, which was fictitiously presented as provisional, could still be rejected by the national Parliament. The renunciation of Italian sovereignty over the ex-zone B was therefore depicted by right-wing parties as a dangerous political act that not only insulted the memory of both the martyrs of November 1953 and recently deceased former mayor Bartoli, but also shocked those who had undoubtedly believed in the government's commitment to safeguarding Italian sovereignty of the eastern border. Osimo's dubious benefits and the extension of Yugoslav territorial waters, the right claimed, would ultimately inflict a deadly blow to the Triestine economy. For its part, the Independence Movement, while highlighting Osimo's violation of the principle of self-determination and mobilizing about a thousand people in Trieste's square, also claimed that Trieste's economy would suffer. ${ }^{225}$

\footnotetext{
${ }^{224}$ ACT, Verbale Consiglio Comunale, "Seduta Ordinaria," October 8-9, 1975.

${ }^{225}$ ACS, MI, Dipartimento della Pubblica Sicurezza, Cat. G, Associazioni 1944-1986, B.352, Folder Movimento TLT, "Confidential from Tireste Prefect," October 28, 1975.
} 
These opposing and irreconcilable views were also debated within a partially empty Italian Parliament that "sanctioned the definitive exile of the émigrés from their native Istria." 226 Prime Minister Moro received numerous letters from Istrian groups which were filled with disillusionment, anger, and disdain toward a national political class which, in their views, had repeatedly lied and ignored the fate of the nation's natural borders. ${ }^{227}$ For the émigrés, in particular, the signing of Osimo transformed the national government form a "mother into a wicked stepmother, deserving now and forever only the contempt of the Istrian community and the Redipuglia's dead." 228 Although the National League harshly criticized the Treaty, it also argued that the despicable agreement provided the associational network an opportunity to remove Julian patriotism from its demonized nationalist past and contribute to the forging of a new European identity. ${ }^{229}$

On November 10, 1975, Italian Foreign Minister Mariano Rumor and Yugoslav Foreign Minister Milos Minic signed the Osimo Treaty at Villa Leopardi in Ancona. ${ }^{230}$ The Triestine newspaper Il Piccolo portrayed Osimo as "an agreement that unifies rather than divides people across the Adriatic frontier." ${ }^{231}$ Meanwhile, members of the local conservative factions of the Christian Democrats advanced both pragmatic and emotional arguments to oppose the Treaty. Among them, Giorgio Tombesi played a pivotal role in opposing the terms of Osimo, citing its moral injustice and unclear economic benefits. Aware that the Italian cultural and linguistic identity of Trieste had long coexisted with its multinational entrepreneurial foundation, Tombesi used Osimo's economic drawbacks to expose the fallacy of the governmental policy toward the city. ${ }^{232}$ Distancing himself from fascist and revanchist claims, the Triestine Christian Democrat portrayed his opposition to Osimo as a choice of political and moral conscience. In resigning Italian

\footnotetext{
${ }^{226}$ Giuseppe Tramarollo, "Saluto agli esuli," Il Pensiero Mazziniano (November 4, 1975).

${ }^{227}$ “Ne disperati, ne velleitari, una linea per l'irredentismo," Difesa Adriatica (October, 1975).

${ }^{228}$ AUI, Miscellaneous, Folder corrispondenza con personalità del governo 1973-1976, "President of an Istrian association to Moro," October 10, 1975.

${ }^{229}$ In 1975 the vice-President of the "Lega Nazionale" Guido Nobile expressed this concept while reflecting on the meaning of Osimo. Redivo, 159-162.

${ }^{230}$ See Map VII.

231 "Firmato l'accordo sulla zona B," Il Piccolo (November 11, 1975).

${ }^{232}$ Tombesi Interview, March 2012.
} 
Map VII: the State Frontier between Italy and Yugoslavia after Osimo

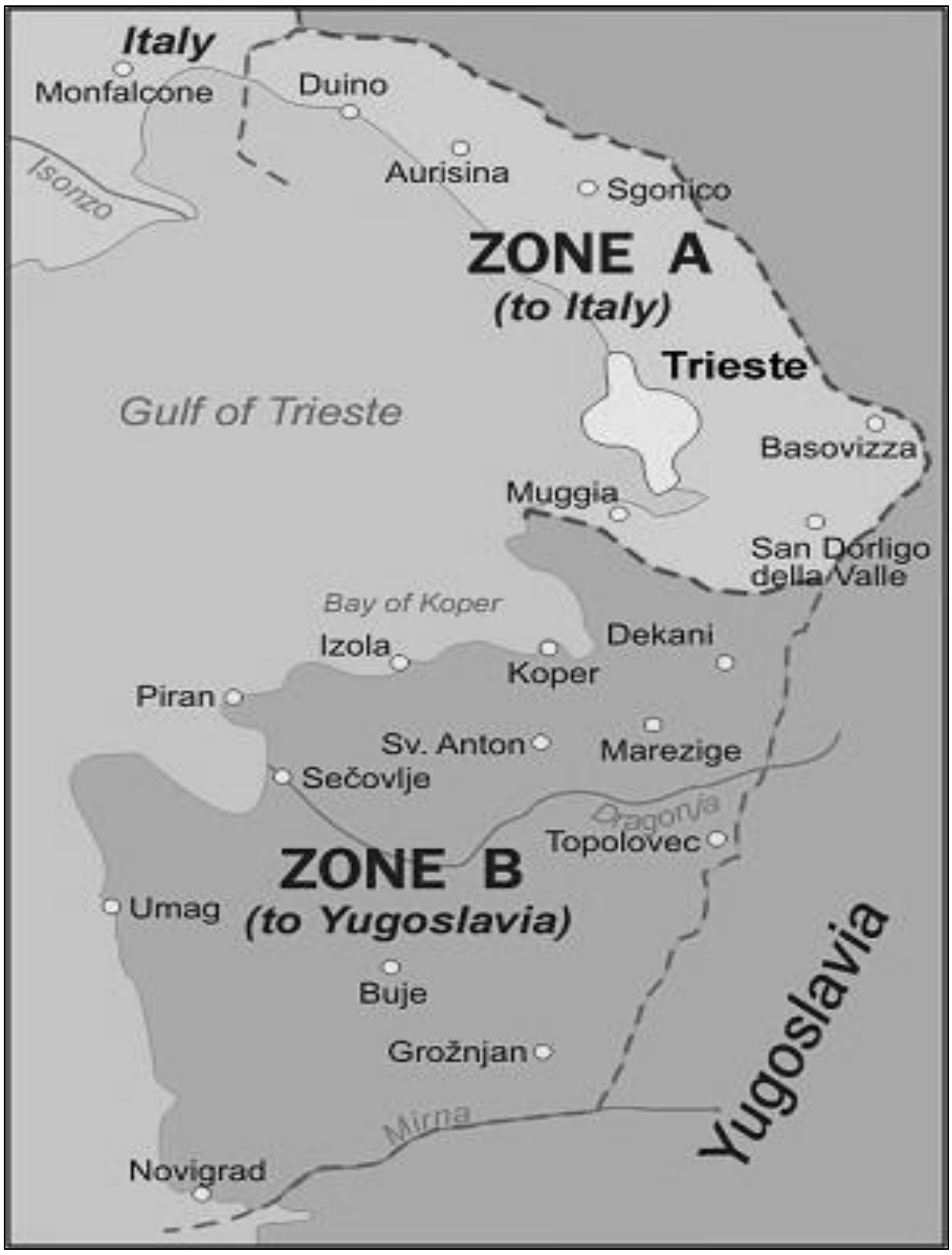


sovereignty over a tiny strip of land that had formally remained under international jurisdiction for the previous thirty years, Tombesi argued, the Italian government ultimately weakened rather than strengthened Italian security along the eastern border. ${ }^{233}$

In Tombesi's views, not only pressure from NATO allies but also Moro's defeatism and personal belief in a political future with the Left had paved the way to Osimo. The "Morotea" faction of the Christian Democrats had indeed prepared for the renunciation of Italian rights to the ex-zone B while simultaneously searching for a compromise with the left. ${ }^{234}$ In addition, the detractors of Osimo were fined by the Christian Democrat secretary for violating party discipline, a fact that only fostered more animosity toward the national party and the state institutions that it dominated. Relying on widespread popular opposition to the economic terms of the treaty, Osimo's detractors in Trieste were able to collect 65,000 signatures in support of the creation of a full free trade zone and administrative autonomy for Trieste. ${ }^{235}$

The Italian government, however, appeared unconcerned about popular disillusionment in Trieste. ${ }^{236}$ Indeed, in multiple reports from the meetings of the Council of Ministers between October 1975 and July 1976, the most heated phase of the protests against Osimo in Trieste, not one reference was made about the border settlement. ${ }^{237}$ Moreover, the parliamentary discussions that anticipated the ratification of the Treaty hardly saw more than twenty to twenty-five representatives participating in the debate, which further confirms its marginalization in Italian national politics. ${ }^{238}$

In Trieste, by contrast, religious figures like Bishop Santin continued to harshly criticize the Christian Democratic Party which, supported by Socialists and Communists, had disregarded the injustice of the Istrian exodus and agreed to the "the sordid barter." ${ }^{239}$ Meanwhile, the National Italian Irredentist Association also led a public campaign against an agreement which they claimed

\footnotetext{
${ }^{233}$ AST, Fondo Tombesi, Busta 20, "Speech at a Local Committee," 1975.

${ }^{234}$ AST, Fondo Tombesi, Busta 21, "Letter from Secretary of DC local section to Tombesi," January 7, 1976.

${ }^{235}$ Gianni Giuricin, Meloni, melonismo, melonaggine (Trieste: Edizioni La Cinigia, 1982), 198.

${ }^{236}$ Flaminio Rocchi, "La zona B regalata alla Jugoslavia," Difesa Adriatica (March 2, 1976).

${ }^{237}$ ACS, PCM, "Verbali Adunanze," October 10, 1975-July 28, 1976.

${ }^{238}$ Tombesi, Unpublished Manuscript (2006).

${ }^{239}$ Santin,"Crisi e vergogna," Vita Nuova (1976).
} 
had "violated the moral duty of the Italian people to accomplish the geo-political unification of the nation." 240 In their views, Osimo was nothing but "an infamous barter."241

The political and popular debate sparked by the Osimo Treaty affected Trieste's loyalty to and identification with the Italian state. ${ }^{242}$ On April 13,1976, in an effort to oppose the prospective creation of a custom zone across the border that would economically benefit Yugoslav companies, local socialist, liberal, republican and pro-independence leaders decided to create a committee named "Il Comitato dei Dieci" (The Ten People Committee). ${ }^{243}$ This committee represented the nucleus of the future "Lista per Trieste" (LPT) movement and proposed the creation of an integral free trade zone to oppose the one foreseen by Osimo. ${ }^{244}$ Most important, the LPT used economic rather than irredentist arguments to demonstrate the wrongful nature of the Osimo Treaty and stressed its detrimental effects on Trieste. ${ }^{245}$ This new movement of political protest represented not only a strong response to national partitocracy but also a reawakening of civic consciousness for a city that was not nationalist but still Italian under a secularly-oriented majority. ${ }^{246}$ Its symbol, the watermelon, which was previously used by the independence front in 1966, symbolized a simple and common man who opposed the intrigues of a corrupt and inefficient political system. ${ }^{247}$

Despite local protests, however, the Triestine city council formally approved the Osimo Treaty and depicted it as a "bridge between West and East" in $1976 .{ }^{248}$ During the political debate, neo-fascist, liberal, and pro-independence political representatives opposed the center-left coalition. ${ }^{249}$ Although the base of the local Republican Party condemned the ignominy of the treaty, the party approved Osimo. ${ }^{250}$ This decision, motivated by the party leadership's support for the

\footnotetext{
${ }^{240}$ AUS, Fondo Luigi Papo, Busta 2, fasc.8, "ANII," June 3, 1976.

241 "Firmato nella clandestinità il patto della vergogna," Il Secolo d'Italia (November 11, 1975).

${ }^{242}$ Alfredo de Donno, “Italia e Jugoslavia," Il Pensiero Mazziniano (December 10, 1975).

${ }^{243}$ Roberto Spazzali, “Trent'anni fa il trattato di Osimo," Tempi \& Cultura (2005).

${ }^{244}$ Valdevit (2004), 120-130.

${ }^{245}$ Cecovini (1968), 204.

${ }^{246}$ Cecovini (1985), 71.

${ }^{247}$ Gianni Giuricin, Origini della Lista per Trieste: storia documentata (Trieste: Edizioni Italo Svevo, 2006), 160.

${ }^{248}$ Massimo Bucarelli e Luciano Monzali, L 'amicizia come destino storico. Italia e Slovenia fra passato, presente e futuro (Roma: Studium, 2009), 109.

${ }^{249}$ FN, Carte Nenni, B.82, Sez.C, "Spaccini to Nenni," November 19, 1976.

${ }^{250}$ Oddo Biasini, "Decisione necessaria," La Voce Repubblicana (October 4, 1975).
} 
process of Adriatic friendship and opposition to neo-fascist propaganda, consequently shattered the party's unity in Trieste. In 1977, the Osimo Treaty was also ratified by the national Parliament. Moro began his speech in Parliament stating that the Yugoslav administration in zone B "was neither alterable with force nor with negotiation." 251 Thus, Moro added, the agreement was a valuable instrument which, even though painful and understandably opposed by the Julian community, finally buried the residual tension that had remained from the Second World War and fostered international peace.

Similar to Italy's signature of the London Memorandum in 1954, Moro attempted to minimize the government's responsibility by presenting the agreement as the outcome of external factors that forced the Christian Democrats to accept a de facto situation that had lasted for thirty years. Moro's parliamentary opponents, for their part, reiterated their criticism of the incredibly secretive nature of the agreement, the lack of significant economic benefits, and its contribution to the advancement of international Communism. ${ }^{252}$ All of these arguments were certainly filled with nationalist rhetoric yet also highlighted some of the main flaws of the Osimo Treaty.

These flaws were also noted by conservative Christian Democratic figures, among them Triestine representative Giacomo Bologna. Bologna opposed the treaty stating that Osimo was “avoidable, unnecessary and useless. ${ }^{, 253}$ Bologna argued that the London Memorandum had fostered mutual cooperation between Italy and Yugoslavia over time and had created the most open border in Europe. The formal recognition of Yugoslav sovereignty, while finally dashing the aspirations of the émigrés and violating the Helsinki spirit, he continued, stemmed from the increasing political pressure that Tito exercised on the Italian government. In Bologna's words, "while the London Memorandum was comprehensible, Osimo was suicidal and unacceptable." 254

These views were also echoed by the C.N.C. in 1977. Indeed, while arguing that the ItalianYugoslav agreement was constitutionally illegitimate and violated international law, the Committee

\footnotetext{
${ }^{251}$ Aldo Moro, Senato della Repubblica, VII Legislatura, February 23,1977.

${ }^{252}$ See Carlo Montani, Il trattato di Osimo (10 novembre 1975) (Firenze: Risma, 1991).

${ }^{253}$ Giacomo Bologna, A salvare la patria c'ero anch 'io. Forse (Trieste: Italo Svevo, 2001), 115.

${ }^{254}$ Ibid., 88.
} 
appealed to Italian President Giovanni Leone, urging him to not sign the Osimo Treaty. ${ }^{255}$ The treaty, however, was formally ratified and, outside of Trieste, was perceived for the most part as a constructive model for an Adriatic bridge. ${ }^{256}$ Within public discourse, the political opposition sought to exploit the sentimental value of the ex-zone B and accused the Christian Democrats of betraying national interests. Local political conservative groups also stressed that Osimo had created an irreparable fracture between the Triestine people and the state.

This argument became central to the propaganda of the LPT. The movement, which was led by local social-democratic and liberal political representatives who were former members of the Triestine center-left coalition government, opposed the Christian Democratic Party in Trieste. Their protest against Osimo won increasing popular support and culminated in the election of its leader, liberal Manlio Cecovini, to the position of mayor of Trieste in $1978 .{ }^{257}$ The LPT identified itself with Trieste's past municipal tradition and advocated the protection of the city's cultural and economic interests over those of the Italian nation-state. In particular, the LPT became the political voice of the diverse Italian, cosmopolitan, and municipal identities that coexisted in the city. ${ }^{258}$ The movement ultimately prevented a possible new escalation of dangerous nationalist feelings and enhanced sentiments of local identity or "Triestinità.",259

As Tombesi effectively summarized in his 1978 parliamentary speech, the success of the LPT not only exposed local animosity against the ambiguous economic benefits of Osimo but it also revealed Trieste's hostility toward the Christian Democratic governing elites, whom over the years had not been able to respond to Trieste's needs. ${ }^{260}$ Indeed, years of ineffective state administration ultimately fuelled local nostalgia for past forms of administrative autonomy and, at

\footnotetext{
${ }^{255}$ See Centro Nazionale di Coordinamento per la Salvezza di Trieste nell'interesse della pace. Il trattato di Osimo. (Trieste: Centro Culturale G.R. Carli, 1976).

${ }^{256}$ FBIS (February 25, 1977).

${ }^{257}$ Vezzà and Comelli, 216.

${ }^{258}$ Lanzardo, 20.

${ }^{259}$ Ara and Magris (2007), 186.

${ }^{260}$ AST, Fondo Tombesi, Busta 12, "Tombesi’s Speech in Parliament," June 1978.
} 
the same time, weakened local allegiance to the Italian state idea. ${ }^{261}$ While championing the city's former role as a gate to the East as well as crucible of Italian, German, and Slovene civilizations, the political phenomenon of the LPT represented the fervent response of the border's community to the state's perceived violation of both its Italian and commercial identity. ${ }^{262}$ These two specific features united Socialists, Republicans, Liberals, and Democrats who felt unrepresented in Rome.

One of its main figures, Socialist representative Gianni Giuricin, argued that Osimo was hardly disputable in rational terms yet was unacceptable on the basis of morality, justice, and political conscience. Due to Osimo's violation of self-determination Giuricin had decided to abstain from voting on the Treaty in the Triestine city council. ${ }^{263}$ Meanwhile, Giuricin also proposed a demonstration of Trieste's opposition to the Treaty through the closure of the city council for a day and the flying of the Italian flag at half staff. In rallying together multiple political formations whose ideological views appeared to be irreconcilable, Osimo effectively deepened the existing political fracture between Roman and Triestine political elites.

To contain the detrimental effects that the local campaign against Osimo could potentially have on the regional elections of 1978, the Christian Democrats imposed strict discipline on the local party and replaced local candidates who had shown their hostility to the Italian-Yugoslav agreement. $^{264}$ The party also increased its support for pro-Osimo candidates and cut financial support to its detractors. In spite of this, the LPT won the Triestine elections with 51,561 votes (27.5\%). In addition, at the national elections of 1979, Christian Democratic candidates like Giorgio Tombesi, who counted on the support of the émigré community, received more votes that Corrado Belci, a strong supporter of Osimo in Trieste. ${ }^{265}$ Both the 1978 victory of the LPT and Tombesi's election in 1979 proved the widespread hostility toward the center-left majority of the Christian

\footnotetext{
${ }^{261}$ Carl Schiffrer, "La Città declassata," in Dopo il ritorno dell'Italia. Trieste 1954-1969. Scritti ed interventi polemici, ed. Giorgio Negrelli (Udine: Del Bianco, 1992), 89-96.

${ }^{262}$ Sapelli, 323.

${ }^{263}$ Giuricin (2006), 28.

${ }^{264}$ In this context Bologna, a traditional supporters of the "Italianitá" of the zone B, was replaced byTombesi for the 1979 national elections.

${ }^{265}$ Tombesi received 11,173 vote against 10,126 for Belci while in overall term the DC achieved the $36 \%$ of popular support.
} 
Democratic Party whose policies were perceived as subservient to advancing socialism and offensive to the moral, political, and historical values of the city and its émigrés.

\section{Ending the Istrian Question}

This chapter has stressed that the Osimo Treaty was the conclusion of a long-term diplomatic process that decisively accelerated after the Prague Spring and ultimately sanctioned the definitive partition between Trieste and its Istrian region. ${ }^{266}$ The Treaty also represented the end of residual popular irredentist ambitions that had survived the territorial agreements of both 1947 and 1954. In the views of the local Italian community and, especially, the émigrés, the creation of the state frontier broke the historical, cultural, and economic foundation that made Trieste and Istria a "unique entity within the nation's imagined community."267

After 1954 Triestine and Istrian dreams of territorial reunification had indeed gradually diminished and perceptions of Trieste frontier's identity decisively changed. Although local conservatives and intransigent nationalists firmly opposed any change to the geo-political status of the ex-zone B, the most progressive segments of the Triestines population increasingly assessed the border's relationship to the Italian nation-state through the lenses of both the survival of Italian language and culture across the demarcation line and Trieste's economic prosperity.

Thus, in 1975, years of negotiations culminated in Italian recognition of Yugoslav sovereignty over the ex-zone B; however, Trieste's disillusionment with the deceptive behavior of the Christian Democratic governing elites and the economic terms of the agreement sparked an unparalleled revival of local identity. ${ }^{268}$ From the Triestine perspective, after years of promises and lies, not only did the national elites sell out Istrian martyr Nazario Sauro's dreams but they also

\footnotetext{
${ }^{266}$ Bucarelli, ed. Garzia (2011), 148.

${ }^{267}$ The idea of nation as an abstract space of brotherhood and liberty that crossed the Adriatic border was well summarized in Pantaleo Ingusci, "Mazzinianesimo e patriottismo in Italia," Il Pensiero Mazziniano (April 25, 1971).

${ }^{268}$ Manlio Cecovini, Dare e avere per Trieste: scritti e discorsi politici, 1946-1979 (Udine: Del Bianco, 1991$), 107$.
} 
imposed an artificial border which, located in a tiny and historically borderless region, further threatened Trieste's economy. ${ }^{269}$

Outside Trieste, however, Osimo was the final step to complete the partition of a border that faced a Communist threat, had already been lost, and would finally remove the ghosts of past nationalism. ${ }^{270}$ Indeed, for the Christian Democratic elites, Osimo offered Trieste an outstanding opportunity to play a pivotal role in the Danubian economy. ${ }^{271}$ The emotional reasoning of the neoirredentist associations, however, strongly clashed with the pragmatism of the central government. ${ }^{272}$ Above all, these divergent understandings of the meaning and importance of Osimo marked the last chapter of the legacy of the "mutilated victory" which, in post-war Italy, ironically became a mutilated defeat, this time by means of diplomacy and politics rather than war and violence.

\footnotetext{
${ }^{269}$ Sapelli, 257.

${ }^{270}$ Belci (1989), 192.

${ }^{271}$ Sergio Segre, “Un avvenire per Trieste,” Rinascita (December 17, 1976).

${ }^{272}$ Domenico Sassoli, “Firmato l'accordo Italia-Jugoslavia," Il Popolo (November 10, 1975).
} 


\section{Conclusion}

Although historians have extensively studied the Trieste question for the years from 1945 to 1954 , only a few have paid close attention to the prolonged dispute over the territory south of the city of Trieste, namely the zone B, the northern part of the Istrian region. In labeling this issue as less significant, the narrative of the Cold War dispute over Italy's eastern border, therefore, has remained incomplete. This in-depth study of the border dispute over Trieste and its territory has shown that the northern area of the Adriatic region, located on the southern point of the "Iron Curtain," actually remained an object of contention between the Italian and Yugoslav governments within the broader context of the Cold War until the 1970s.

In discussing the problem of Trieste and its territory, this work has broadened the historical understanding of the political process that led to the definition of the Italian and Yugoslav frontier, almost thirty years after the Paris Peace Treaty. It has proven that the post-war Republic underscored the image of the Triestine territory as the geo-political extension of both the Italian nation and Western democracy. As in the past, Trieste and its territory were used by a variety of political actors to promote national unity and, above all, redefine the new political identity of a shattered nation as an anti-thesis to Yugoslav Communism. Once more, Italy's eastern border became the defining force of Italian nationhood after 1945.

In investigating the post-war dispute over Trieste and its territory, this study has made two main contributions. First, it has provided valuable insight into the politics of identity and the fluid nature of borders during the Cold War. Second, it has demonstrated that, in a context of post-war reconstruction, border disputes significantly affected both local and national politics, ultimately strengthening or weakening people's loyalty toward state institutions.

From World War Two to the Osimo Treaty, the territorial dispute over Italy's eastern border was greatly affected by both the dynamic logic of the Cold War and changes in national politics. As Italian central authorities, mainly Christian Democrats, attempted to maximize political and economic interests, they were also determined to shape the image of Italy's Yugoslav neighbor, 
initially in hostile terms, but subsequently in conciliatory terms. To achieve this goal, they employed a wide network of newspapers, political groups, and state agencies. The border dispute, therefore, became a powerful political resource to shape both local as well as national views toward Tito's regime either as a threat to the young Italian democracy or a bastion against Soviet imperialist goals.

Consequently, the boundary between Trieste and its territory transformed from a wall into a bridge within public discourse. Until 1954, the Cold War's ideology of containment made the Adriatic city a stronghold of Western civilization and barrier to Slav-Communism. Housing the ideological confrontation between supporters of the Western and the Eastern world, Trieste also experience episodes of urban violence and became the "Berlin of the Adriatic." This perspective, which relates to the arguments outlined in the previous chapters, offers an interesting key to better understand the impact of the Cold War on urban communities. ${ }^{1}$ Indeed, both cities became the object of a war-time "race" between the Allied and the communist forces, resulting in weeks of prolonged Communist occupation which left an indelible mark on the cities' memories. After the end of war, both Trieste and West Berlin experienced Allied occupation and greatly benefited from the massive financial support of the Marshall Plan to accelerate the reconstruction of their post-war economies and sustain their processes of democratization.

Despite this, the cities' experiences and trajectories also significantly differed from one other. The Triestine territory was disputed between the Cold War's junior powers and never witnessed Allied and Soviet troops confronting each other across the Adriatic. In addition, the Trieste question was characterized by an ethno-political dimension that did not apply to Berlin; the German city, instead, was divided along ideological lines which separated Germans in the West from Germans in the East. Although Italian residents did not experience physical separation inside Trieste, the majority of the population living inside the Triestine territory was ethnically Italian.

\footnotetext{
${ }^{1}$ For a work that investigates the rise and fall of the Berlin wall and its geo-political ramifications see Fred Taylor, The Berlin Wall: a World Divided 1961-1989 (New York: Harper Collins, 2006). Also, for a recent work that explores how the Berlin Wall affected ordinary East Germans, see Patrick Major, Behind the Berlin Wall: East Germany and the Frontiers of Power (Oxford: Oxford University Press, 2010).
} 
Thus, Italy and Yugoslavia competed to affirm their ideologies and assert their territorial rule over a border which they believed was Italian or Slav in its essence.

Moreover, while Berliners were physically separated by a wall, both Italians and Slovenes inside the Triestine territory were separated by an extremely porous demarcation line. Although political tension, military incidents, and restrictions on the movement of people and goods applied to the boundary between Trieste and its territory, it ultimately became the most open border of the Cold War, a condition that did not apply to Berlin. Finally, the territorial dispute over Trieste ended with a diplomatic agreement in 1954 while the dispute over Berlin lasted until 1989 and marked the end of the Cold War.

Nonetheless, in both cities the political language and representation of their respective neighbors emphasized the stark contrast between democracy and Communism, ultimately reinforcing Cold War stereotypes that would crystallize in public views and re-emerge after the end of the bi-polar confrontation. In Trieste, for example, local Slovenes were portrayed as an extension of Tito's Communism and the medium to achieve Trieste's Balkanization. This perceived threat remained central to the propaganda of a variety of political groups, movements, and associations that, aligning or diverging from the official rhetoric of the central government, accentuated or debilitated the peril of Yugoslav Communism.

Most importantly, both Trieste and Berlin became barometers of the Cold War in Europe, witnessing political tensions that brought states with opposing ideologies to the brink of military confrontation. While Trieste was marred by conflict in the immediate post-war years, it later greatly benefited from political relaxation. Indeed, as this study has shown, 1954 marked a watershed for Trieste. After returning under Italian sovereignty, Trieste was portrayed as an invaluable bridge toward the Socialist world. The Italian government, therefore, while hoping to restore Trieste's port economy and prove the advantages of democracy, firmly pursued a Cold War strategy of détente toward Yugoslavia. Although the Istrian problem continued to pollute the diplomatic relationships between Rome and Belgrade, the Italian establishment pursued a new understanding with Tito and, 
greatly anticipating future developments in international politics, minimized national interests in favor of "habits of mutual restraint, coexistence, and ultimately cooperation."2

In addition, studying the Italian and Yugoslav dispute over the border has offered a unique opportunity to further deepen our understanding of the political relationship between national governments and frontier cities during the Cold War. What emerges from this study is the image of Trieste as a city that, located at the forefront of the Cold War, experienced a sense of gradual isolation, decadence, and abandonment. In recent years, literary works such as Jan Morris's “Trieste and the Meaning of Nowhere" have magnificently exposed this distinct character of the city and its population. In furthering Morris' perspective, this study has depicted post-war Trieste as a city that, while being crossed by political uncertainty and fear, was in search of its past prosperity and well being.

Thus, in the immediate post-war years, multiple political actors elaborated a wide set of political allegiances which firmly supported the extension of Italian statehood to the city and its territory. Local and central governing elites, which were dominated by the Christian Democrats, indeed, worked together to maximize territorial ambitions that were best served by the logic of the early Cold War in the Adriatic. Although their original goals coincided with each other and mirrored the expectations of the local population, their strategies gradually diverged, ultimately producing tension, misunderstanding, and incidents of political violence.

This complex legacy also affected the relationship between Trieste and Rome after 1954. The Italian government, firmly distancing itself from its past nationalist outbursts and confrontational politics, opened to the political forces on the left of the Italian political spectrum. When dealing with the border, therefore, it gradually downplayed its previous anti-communist rhetoric in favor of a new and fruitful political relationship with Tito's regime. Thus, the search for a new progressive policy toward leftist political forces transposed from the realm of domestic to

\footnotetext{
${ }^{2}$ John Lewis Gaddis, Strategies of Containment: a Critical Appraisal of American National Security Policy During the Cold War (Oxford: University Press, 2005), 281.
} 
foreign policy, significantly proving the existence of mutual influence and interaction between national and international politics in the age of the Cold War.

The dissertation has stressed that this political process, greatly facilitated by the political pragmatism of a new progressive leadership, the practice of secret negotiations, and an international consensus on the unchangeable nature of post-war borders, led to the final settlement of the border dispute, the Osimo Treaty. This agreement, however, strained political relations between local and central governing elites and, more importantly, challenged Trieste's loyalty toward the Italian state. The result was the aftermath of a historical process that began after 1945 and eroded Trieste's reservoir of confidence toward the Italian state and its institutions. Above all, while undermining the identification of local Italians in Trieste with state institutions, Osimo also exposed the inescapable connection between local, national, and international politics.

Not only has the study of this border dispute highlighted the complex interaction between multiple political layers, but it has also provided insight into the invaluable role that the politics of identity played in the most heated days of the Triestine problem. Indeed, until 1954, the strong antiCommunist and nationalist rhetoric of the central government projected the image of a border that was both ethnically and territorially Italian and located on the southern frontier of the "Iron Curtain.” In making the geographical extension of Italy’s eastern border the territorial frontier of Western democracy, it also greatly reinforced local political loyalty toward the state.

Trieste's return to Italian sovereignty, however, marked the end of Italy's residual nationalist ambitions toward the territory under Yugoslav administration. Above all, it forced the Italian government to re-think its politics of identity according to the new imperatives of the Cold War. Consequently, while the zone B became a political issue for public consumption, the Italian state attempted to project a new image of Trieste that highlighted the city's role as a point of contact rather than conflict with the East. Trieste, therefore, was defined in European and cosmopolitan terms, as a radiating center of Western modernity and opulence. 
While this new image best responded to changes in international and national politics, it only partially accounted for local political views. Indeed, the wartime memories of the city, the legacy of the Allied occupation, and years of Cold War propaganda reinforced negative views toward Tito's Yugoslavia. Consequently, years of nationalist and anti-Communist rhetoric combined with a seemingly relentless economic decline which, while discrediting the efforts of the Italian administration, ultimately consolidated local views of a state which proved indifferent to the city's needs. As a result, local ambitions for home rule gradually re-emerged and, following the public debate on Osimo, Trieste witnessed the success of autonomist movements. Thus, the Triestine case has proven that while the new course of Cold War politics might have decisively molded former political views, peripheral communities continued to view their lives through the lenses of their past and reacted accordingly to it.

In sum, this intensive study of Trieste has demonstrated that the complex "Pax Adriatica" of the 1960s anticipated international détente, was accompanied by the rise of progressive views in Italian politics, and produced public acquiescence as well as resilience to the state's representation of the communist neighbor. This process of re-conceptualization of the "other" was centered upon political practices of cooperation and dialogue which, over time, changed and strongly affected the post-war rhetoric of nationhood. In frontier cities such as Trieste, the politicization of its acclaimed Italian identity or "Italianità" furthered the goals of the early Cold War. At the same time, it also significantly impaired the process of socio-political rapprochement with Yugoslavia and the local Slavic community, ultimately unleashing local expressions of hostility against the Italian establishment once it turned to a new friendly policy toward Yugoslavia.

Above all, the Triestine and Istrian question has shown the fluidity of the Cold War's Adriatic border, its changing representation within public discourse, and its malleable nature. While this region became a theatre of ideological confrontation until 1954, it then transformed into a space of negotiation that best exemplified the policy of peaceful co-existence. Years of political tensions 
between Rome and Belgrade that were concealed under the rhetoric of Adriatic friendship, however, left a turbulent legacy that re-emerged after 1989.

Following the collapse of Yugoslavia's communist regime, the atrocities of the Yugoslav wars of succession and its related phenomena of mass migration were used by both right-wing Italian political parties and the Italian press to draw parallels with the suffering of the Adriatic émigrés and re-open the heated question of their abandoned properties. In particular, the right-wing coalition government retrieved the tragedy of the "foibe" from years of silence and publicly used it to reinforce Italian sentiments of national unity. From this perspective, the Day of National Remembrance, originally intended to commemorate the victims of the "foibe," became the object of political manipulation and highlighted the detrimental effects of the public use of history. Meanwhile, the end of the Cold War also offered Trieste a unique opportunity to play its past role of a cosmopolitan and entrepreneurial maritime city.

From this perspective, the accession of the Republic of Slovenia and other Eastern European countries to the European Union in 2004 marked a decisive step in the political process of European enlargement toward the East. Europe, which experienced the disruptive effects of competing nationalisms and Cold War ideology, furthered its process of political unity across what was once known as the Iron Curtain. For Trieste and its former territory this meant the return to its Habsburg past, a time in which the north-eastern part of the Adriatic was a unique and borderless region. Thus, this multilingual and multicultural space, which thrived as a wealthy Habsburg municipality, and symbolized both the madness of twentieth-century nationalism and the political dialectic of anti-Communism, has again become a crossing point of different cultures and people who now may fulfill Tommaseo's dreams of unity within diversity. 


\section{Bibliography}

\section{Primary Sources}

a. Unpublished Archival Sources

Archivio Centrale di Stato (ACS), Rome (Italy)

Carte Moro

Atti Personali 1964-1977

Presidenza del Consiglio 1963-1968

Ministero Affari Esteri 1969-1972

Ministero Affari Esteri 1973-1974

Fondo Ministero Interni (MI), Fasc. Permanenti, Prefetture-Prefetti 1944-1966

Fondo Ministero Interni (MI), Schedario Partiti Politici 1944-1966

Fondo Ministero Interni (MI), Divisione Affari Riservati 1954-1975

Fondo Ministero Interni (MI), Gabinetto 1954-1975

Fondo Ministero Interni (MI), Direzione Generale Assistenza Pubblica 1949-1977

Fondo Ministero Interni (MI), Dipartimento della Pubblica Sicurezza 1944-1986

Fondo Presidenza del Consiglio dei Ministri (PCM), Verbali Adunanze 1954-1977

Fondo Presidenza del Consiglio dei Ministri (PCM), Ufficio Consigliere Diplomatico 1954-1975

Archivio Comune di Trieste (ACT), Trieste (Italy)

Verbali Consiglio Comunale 1954-1976

Archivio di Stato Trieste (AST), Trieste (Italy)

Fondo Commissarriato Generale del Governo del Territorio di Trieste (CGGTT)

Fondo Bartoli

Fondo Coceani

Fondo Tombesi

Archivio Diocesi di Trieste (DT)

Fondo Coloni

Archivio Fondazione Istituto Gramsci (AFG), Rome (Italy)

Fondo Archivio Partito Comunista (Apc), 1954-1975

Fondo Mosca

Fondo Vidali

Archivio Fondazione Ugo Spirito (AUS), Rome (Italy)

Fondo Luigi Papo

Archivio Ministero Affari Esteri (MAE), Rome (Italy)

Telegrammi 1954-1975

Archivio Ufficio Zone di Confine (UZC), Rome (Italy)

Sezione II,

Fondo Comitati e Associazioni

Fondo Contributi, Sussidi e Spese

Fondo Fiume

Fondo FVG 
Fondo Jugoslavia e Varie

Fondo Pola e Venezia Giulia

Fondo Profughi

Fondo Trieste

Sezione IV, Ufficio Zone di Confine all'Ufficio Regioni (Trieste e Provincia)

Sezione V, Dall'Ufficio per le Zone di Confine all'Ufficio Regioni Friuli Venezia Giulia Fondo Trieste Contributi

Sezione VI Dall'Ufficio Zone di Confine all'Ufficio Regioni-Capitoli di Spesa (Trieste e Provincia)

Archivio Lega Nazionale (ALN), Trieste (Italy)

Segreteria Riservata 1954-1975

Segreteria Politica 1954-1975

Segreteria Speciale 1954-1975

Carteggio Nobile

Archivio on-line Senato, Rome (Italy)

Fondo Cassiano

Archivio Stato Maggiore Esercito Italiano (ASME), Rome (Italy)

I-5 SIM 1

Archivio Storico Camera dei Deputati (AC), Rome (Italy)

Fondo Covelli

Archivio Storico Senato della Repubblica (ASR), Rome (Italy)

Fondo Martino

Fondo Fanfani (Diari 1954-1972)

Attività Politica

Archivio Unione Istriani (AUI), Trieste (Italy)

Fondo Partizione 1954-1967

Fondo Partizione 1967-1987

Fondo Miscellaneo

Fondo CNC

Fondazione Istituto per la Storia dell'Età Contemporanea (ISEC), Milano (Italy) Fondo Gasparotto

Fondazione Museo Storico del Trentino (FMSdT), Trento (Italy)

Fondo Associazione Nazionale Trento Trieste

Fondazione Nenni (FN), Rome (Italy)

Carte Nenni

Istituto Don Sturzo (ASL), Rome (Italy)

Fondo Democrazia Cristiana 1954-1975

Fondo Mario Scelba

Istituto Regionale per la Cultura Istriana (IRCI), Trieste (Italy)

Fondo CLN, Dichiarazioni Politiche 
Istituto Regionale per la Storia del Movimento di Liberazione Friuli Venezia Giulia (IRSML FVG), Trieste (Italy)

Fondo Venezia Giulia

Fondo Bruno Pincherle

Fondo Poli

Library of Congress (LC), Washington DC (USA)

Records of Clara Boothe Luce

National Archives and Records Administration (NARA), College Park, MD (USA)

CREST, Central Intelligence Bulletin, Yugoslavia-Italy

Foreign Intelligence Aid

National Intelligence Estimates Microfish

RG 59, Records of the Office of the Western European Affairs, 1941-1954, Subject Files

RG 84, Foreign Service Posts of the Department of State, Italy, U.S. Embassy Rome

RG 263 Records of the Central Intelligence Agency

b. Published Archival Sources

FRUS Foreign Relations of the United States

UN Official Records of the Security Council

OCI Office of Current Intelligence, Central Intelligence Agency

AP Atti Parlamentari, Camera dei Deputati (Parliamentary Acts, Chamber of

Representatives)

c. Public Press

Avanti

Corriere di Trieste

Difesa Adriatica

Domenica del Corriere

Il Borghese

Il Corriere della Sera

Il Giornale d'Italia

Il Lavoratore

Il Pensiero Mazziniano

Il Piccolo

Il Ponte

Il Popolo

Il Secolo d'Italia

Il Tempo

L'Indipendente

L'Italiano

L'Unità

La Grande Italia

La Voce della Patria

La Voce Repubblicana

Le Ultime Notizie 
Rinascita

Tempi \& Cultura

The Nation

The New York Times

Tribuna Monarchica

Trieste

Vita Nuova

\section{d. Governmental materials}

Foreign Broadcast Information Service (FBIS)

Istituto Centrale di Statistica del Regno d'Italia, VIICensimento Generale della Popolazione

Istituto Centrale di Statistica del Regno d'Italia, VIIICensimento Generale della Popolazione

e. Oral Interviews

Giorgio Tombesi, March-September 2012, Trieste (Italy)

f. Coeval literature

Agnelli, Arduino. Questione nazionale e socialismo. Bologna: Il Mulino, 1969.

Battisti, Ernesta. Italianità di De Gasperi. Firenze: Parenti Editore, 1957.

Coceani, Bruno. Milano centrale segreta dell'irredentismo. Milano: La Stampa Commerciale, 1962.

Cusin, Fabio. Antistoria d'Italia: una demistificazione della storia ufficiale: un'Italia sotto luce diversa. Milano: Mondadori, 1970.

Fogar, Galliano. Dall'irredentismo alla resistenza nelle provincie adriatiche:Gabriele

Foschiatti. Udine: Del Bianco, 1966.

Gayda, Virginio. Modern Austria, Her Racial and Social Problems. London: T.F. Unwin, 1915.

Mirabelli, Roberto. Dalla Libia a Vittorio Veneto et ultra. Milano: Società Editrice Dante Alighieri, 1932.

Sabbatucci, Giovanni. I combattenti nel primo dopoguerra. Roma: Laterza, 1974.

Silvestri, Claudio. Dalla redenzione al fascismo. Trieste 1918-1922. Udine: Del Bianco, 1959.

Tamaro, Attilio. L'Adriatico golfo d'Italia l'italianità di Trieste. Milano: Treves, 1915.

Tamaro, Attilio. Trieste, storia di una città e di una fede. Milano: I.E.I, 1946.

Valussi, Pacifico and Constantino, Ressman. Trieste e l'Istria e le loro ragioni nella questione italiana. Milano: Libreria Brigola, 1861.

Vivante, Angelo. L'Irredentismo Adriatico. Trieste: Italo Svevo Edizioni, 1984.

Slapater, Scipio. Il mio Carso. Milano: Mondadori Editore, 1962.

Tamburrano, Giuseppe. Storia e cronaca del centro-sinistra. Milano: Feltrinelli Editore, 1971.

\section{g. Audio-Visual Material}

Fondazione Archivio Audiovisivo del Movimento Operaio e Democratico (Audio-Visual Archive of the Worker Democratic Movement, AAMOD), Rome (Italy) 


\section{Secondary Sources}

Aaslestad, Katherine. Place and Politics. Local Identity, Civic Culture, and German Nationalism in North Germany during the Revolutionary Era. Boston: Brill, 2005.

Albertini, Paolo Sardos. Lega Nazionale storia di un sodalizio che attraversa tre secoli. Trieste: Lega Nazionale, 2011.

Anderson, Benedict. Imagined Communities. London: Verso, 1983.

Anonymous. La Jugoslavia sotto il terrore di Tito. Roma: Edizioni di Cultura Sociale, 1949. Apih, Elio. Trieste. Bari: Laterza, 1988.

Apollonio, Almerigo. Autunno istriano: la rivolta di Pirano del 1894 e i dilemmi dell'irredentismo. Trieste: Edizioni Italo Svevo, 1992.

Ara, Angelo e Eberhard Kolb. Regioni di frontiera nell'epoca dei nazionalismi: Alsazia e Lorena / Trento e Trieste. Bologna: Il Mulino, 1995.

Ara, Angelo e Claudio Magris. Trieste: un'identità di frontiera. Torino: Einaudi, 2007.

Arthurs, Joshua. Excavating Modernity: the Roman Past in Fascist Italy. Cornell: University Press, 2012.

Ashbrook, John. "Politicization of Identity in a European borderland: Istria, Croatia, and authenticity, 1990-2003." Nationalities Papers 39 (6) (November 2011): 877-897.

Atkin, Nichola (ed.). Daily Lives of Civilians in Wartime Twentieth-Century Europe. London: Greenwood Press, 2008.

Ballinger, Pamela. History in Exile. Princeton: University Press, 2003.

Ballini, Pier Luigi, Alfredo Canavero e Francesco Malgeri. Alcide De Gasperi. Catanzaro: Soveria Mannelli, 2009.

Banti, Alberto. La nazione del Risorgimento: parentela, sanità, e onore alle origini dell'Italia unita. Torino: Giulio Einaudi, 2000.

Banti, Alberto, e Roberto Bizzocchi. Immagini della nazione nell'Italia del Risorgimento. Roma: Carocci Editore, 2002.

Barbagallo, Francesco (ed.). Storia dell'Italia Repubblicana. Torino: Giulio Einaudi, 1995.

Baroni, Rino. Gli istriani in difesa dell'Istria italiana: dal Memorandum d'Intesa al Trattato di Osimo. Trieste: Unione degli Istriani, 2004.

Battini, Michele. The Missing Italian Nuremberg: Cultural Amnesia and Post-War Politics. New York: Palgrave MacMillan, 2007.

Bedani, Gino, and B. A. Haddock (ed.). The Politics of Italian National Identity: a Multidisciplinary Perspective. Cardiff: University of Wales Press, 2000.

Belci, Corrado. Trieste memorie di trent'anni (1945-1975). Brescia: Morcelliana, 1989.

Bergholz, Max. "Sudden Nationhood: the Mycrodynamics of Intercommunal Relations in Bosnia-Herzegovina After World War II." The American Historical Review 118 (3) (June, 2013): 679-707.

Bianchini, Stefano. Partitions: Reshaping States and Minds. New York: Frank Cass, 2005.

Blackbourn, David and Richard J. Evans (ed.). The German Bourgeoisie: Essay on the Social History of the German Middle Class from the late Eighteenth to the Early Twentieth Century. New York: Routdlege, 1991.

Bologna, Giacomo. A salvare la patria c'ero anch 'io. Forse. Trieste: Italo Svevo, 2001. Bonucci, Silvia. Voices From a Time: a Novel. New Hampshire: Steerforth Press, 2006.

Bosworth, R.J.B, and Patrizia Dogliani (ed.). Italian Fascism: History, Memory, and Representation. New York: St. Martin Press, 1999.

Brubaker, Rogers. Nationalism Reframed: Nationhood and the National Question in the New Europe. New York: Cambridge University Press, 1996.

Bossi, Licio e Severino Baf. Trieste 1900-1999, Cent'anni di storia, Vol. IX. Trieste: Publisport, 2000. 
Botta, Franco e Italo Garzia (ed.). Europa adriatica: storia, relazioni, economia. Bari: Laterza, 2004.

Bucarelli, Massimo. La "Questione jugoslava" nella politica estera dell'Italia Repubblicana, 1945-1999. Roma: Aracne, 2008.

Bucarelli, Massimo e Luciano Monzali. L'amicizia come destino storico. Italia e Slovenia fra passato, presente e futuro. Roma: Studium, 2009.

Cattaruzza, Marina. L'Italia e il confine orientale, 1866-2006. Bologna: Mulino, 2007.

Cavazza, Silvano, e Giuseppe Trebbi. AttilioTamaro e Fabio Cusin nella storiografia triestina: atti del convegno in ricordo di Arduino Agnelli, Trieste, 15-16 Ottobre 2005. Trieste: Deputazione di Storia Patria per la Venezia Giulia, 2007.

Cecovini, Manlio. Del patriottismo di Trieste. Discorso di un triestino agli italiani nel cinquantenario della redenzione. Milano: all'Insegna del Pesce d'oro, 1968.

Cecovini, Manlio. Trieste ribelle. La lista del melone. Un insegnamento da meditare. Milano: Sugarco, 1985.

Cecovini, Manlio. Dare e avere per Trieste: scritti e discorsi politici, 1946-1979. Udine: Del Bianco, 1991.

Centro Italo-Romeno di Studi Storici. La Stampa italiana e la "Polveriera" d'Europa" (19051919). Verona: Edizione Unicopli, 1988.

Centro Nazionale di Coordinamento per la Salvezza di Trieste nell'interesse della pace. $I l$ trattato di Osimo. Trieste: Centro Culturale G.R. Carli, 1976.

Cervani, Giulio. Gli Scritti Politici di Fabio Cusin nel "Corriere di Trieste." Gli anni della polemica dura 1946-1948. Udine: Del Bianco Editore, 1991.

Cervani, Giulio. Gli Scritti Politici di Fabio Cusin nel "Corriere di Trieste." Gli anni dell'opposizione ragionata 1949-1951. Udine: Del Bianco Editore, 1994.

Cipriani, Armando. Dalla liberazione agli anni '80, Trieste come problema nazionale. Roma: Salemi editore, 1984.

Clementi, Marco. L'Alleato Stalin: l'ombra Sovietica sull'Italia di Togliatti e De Gasperi. Milano: Rizzoli, 2011.

Cocco, Emilio e Everardo Minardi (ed.). Immaginare l'Adriatico: contributi alla riscoperta sociale di uno spazio di frontiera. Milano: Franco Angeli, 2007.

Cohen, Gary. Educational and Middle-Class Society in Imperial Austria 1848-1918. West Lafayette, Indiana: Purdue University Press, 1996.

Cole, Laurence (ed.). Different Paths to the Nation. New York: Palgrave MacMillan, 2007.

Confino, Alan. The Nation as a Local Metaphor: Wurttemberg, Imperial Germany, and National Memory,1871-1918. North Carolina: University Press, 1997.

Cooke, Philip. The Italian Resistance: An Anthology. New York: St. Martin Press, 1997.

Cooke, Philip. Luglio 1960: Tambroni e la repressione fallita. Milano: Teti Editore, 2000.

Cooke, Philip. The Legacy of the Italian Resistance. New York: Palgrave MacMillan, 2011.

Cresciani, Gianfranco. Trieste Goes to Australia. Lindfield, NSW: Padana Press, 2011.

D'Alessio, Vanni. "From Central Europe to the Northern Adriatic: Habsburg Citizens between Italians and Croats in Istria." Journal of Modern Italian Studies 13(2) (2008): 237-258. .

D'Amelio, Diego. "Il cambio della guardia. Correnti, generazioni e potere nella Democrazia Cristiana di Trieste (1954-1966)." Quaderni del centro studi economico politici Ezio Vanoni (3-4) (2009): 1-64.

Damien, Elsa. "The Reversal of the Myths: Venetian Historiography and Adriatic Nationalism (1897-1922)." Paper presented at the annual conference for the Association for the Study of Modern Italy, London, UK, November 19-20, 2010.

De Castro, Diego. La questione di Trieste: l'azione politica e diplomatica italiana dal 1943 al 1954 (2 vols).Trieste: Lint, 1981.

Delbello, Piero. I Ragazzi del '53: l'insurrezione di Trieste cinquant'anni dopo. Trieste:

Edizioni Italo Svevo, 2003. 
Delbello, Piero. Esodo. Trieste: I.R.C.I., 2004.

Delbello, Piero, e Roberto Spazzali. La sconfitta rimossa: 1947-2007 a sessant'anni dal Trattato di Pace. Trieste: IRCI, 2008.

De Leonardis, Massimo. "Il Confine Orientale dell'Italia." Storia Urbana 117 (2007): 71-87.

Dessardo, Andrea. Vita Nuova 1945-1965. Trieste nelle pagine del settimanale diocesano.

Trieste: Irsml, 2010.

Di Nolfo, Ennio. Power in Europe? II: Great Britain, France, Germany, and Italy and the Origins of the EEC, 1952-1957. New York: W de G, 1992.

Doumanis, Nicholas. Inventing the Nation: Italy. New York: Oxford University Press, 2001.

Donati, Sabina. A Political History of National Citizenship and Identity in Italy 1861-1950. Standford: University Press, 2013.

Drakulic, Slavenka. Cafè Europa: Life after Communism. New York: W.W. Norton \& Company, 1996.

Duggan, Christopher, and Christopher Wagstaff (ed.). Italy in the Cold War: Politics, Culture, and Society, 1948-1958. Washington D.C.: Berg, 1995.

Eley, Geoff, and Ronald Suny (ed.). Becoming National. New York: Oxford University Press, 1996.

Finzi, Roberto, Claudio Magris, e Giovanni Miccoli (ed.). Il Friuli Venezia Giulia. Torino: Einaudi, 2002.

Fragiacomo, Paolo. L'industria come continuazione della politica: la cantieristica italiana, 1861 2011. Milano: Franco Angeli, 2012.

Gaddis, John Lewis. Strategies of Containment: a Critical Appraisal of American National Security Policy During the Cold War. Oxford: University Press, 2005.

Galli Della Loggia, Ernesto. La morte della patria: la crisi dell'idea di nazione tra resistenza, antifascismo e Repubblica. Roma: Editori Laterza, 1996.

Ganapini, Luigi (ed.). Anche l'uomo doveva essere di ferro: classe e movimento operaio a Trieste nel secondo dopoguerra. Milano: Franco Angeli, 1986.

Garzia, Italo, Luciano Monzali, e Massimo Bucarelli (ed.). Aldo Moro, l'Italia Repubblicana, e $i$ Balcani. Nardò: Besa, 2011.

Gentile, Emilio. La Grande Italia: ascesa e declino del mito della nazione nel ventesimo secolo. Milano: Mondadori, 1997.

Ghisilberti, Carlo. Adriatico e confine orientale: dal Risorgimento alla Repubblica. Napoli: Edizioni Scientifiche Italiane, 2008.

Giuricin, Gianni. Meloni, melonismo, melonaggine. Trieste: Edizioni La Cinigia, 1982.

Giuricin, Gianni. Origini della Lista per Trieste. Storia documentata. Trieste: Edizioni Italo Svevo, 2006.

Gon, Diego. "Il problema di Trieste 1945-1954." Osservatorio Strategico (7) (July, 2004): 1-87.

Grainger, Ian. "Trieste and the Foibe:Nation and Memory." Bullettin of the Society for Italian Studies 37 (2004): 5-23.

Grassi, Alberto. "Il Corriere di Trieste" tra propaganda e realtà. Un'interpretazione dell'Indipendentismo nel Territorio Libero. Trieste: Hammerle Editori, 2009.

Graziano, Manlio. The Failure of Italian Nationhood: the Geopolitics of a Troubled Identity. New York: Palgrave MacMillan, 2010.

Gualtieri, Roberto. Il PCI nell'Italia Repubblicana1943-1991. Roma: Carocci, 2005.

Hametz, Maura. "Naming Italians in the Borderland, 1926-1943." Journal of Modern Italian Studies 15(3) (2010): 410-430.

Hametz, Maura. Making Trieste Italian, 1918-1954. New York: Royal Historical Society, 2005.

Hametz, Maura. In the Name of Italy: Nation, Family, and Patriotism in a Fascist Court. New York: Fordham University Press, 2012.

Hochscherf, Tobias, Christoph Laucht, and Andrew Plowman (ed.). Divided but not Disconnected: German Experiences of the Cold War. New York: Berghahn Books, 2010. 
Istituto Regionale per la Storia del Movimento di Liberazione nel Friuli-Venezia-Giulia (IRSML). Nazionalismo e Neofascismo nella lotta politica al confine orientale 1945-1975. Trieste: IRCM, 1977.

Judson, Pieter. Guardians of the Nation: Activists on the Language Frontiers of Imperial Austria. Cambridg. Mass: Harvard University Press, 2006.

Karlsen, Patrick, e Stelio Spadaro. L'Altra questione di Trieste: voci italiane della cultura civile giuliana 1943-1955. Gorizia: LEG, 2006.

Karlsen, Patrick. Frontiera Rossa: Il PCI, il confine orientale, e il contesto internazionale 1941-1955. Gorizia: Libreria Editrice Goriziana, 2010.

King, Jeremy. Budweisers into Czechs and Germans: A Local History of Bohemian Politics in 1848-1948. Princeton: University Press, 2002.

Klopp, Charles (ed.). Bele Antiche Storie: Writing, Borders, and the Instability of Identity Trieste, 1719-2007. New York: Bordighera Press, 2009.

Krmac, Dean. "La Popolazione di Trieste a Metà Ottocento. Una Prima Ricostruzione della Topografia dei Flussi Migratori." Rivista Storica Italiana 119(2) (2007): 835-895.

Lanzardo, Liliana. Grandi motori: da Torino a Trieste: culture industriali a confronto, 1966 1999. Milano: Franco Angeli, 2000.

Laven, David. Venice and Venetia under the Habsburg,1815-1835. New York: Oxford University Press, 2002.

Laven, David and Timothy Baycroft. "Border Regions and Identity." European Review of History 15(3) (June, 2008): 255-275.

Lawton, Richard and Robert Lee (ed.). Population and Society in Western European Port-Cities, 1650-1939. Liverpool: University Press, 2002.

Leschi, Vittorio. Le milizie triestine. Mariano del Friuli: Edizioni della Laguna, 2006.

Lorenzo, Nuovo, e Stelio Spadaro. Gli italiani dell'Adriatico Orientale: esperienze politiche e cultura civile. Gorizia: Libreria Editrice Goriziana, 2012.

Maccotta, Walter. "Osimo visto da Belgrado." Rivista di Studi Politici Internazionali (1) (1993): 45-54.

Maggio, Cinzia. La questione giuliano-dalmata nelle carte del Pci : i rapporti tra comunisti Italiani, Sloveni e Croati e l'alba della Guerra Fredda. Roma: Società Dalmata di Storia Patria, 2010.

Maier, Bruno. Gli scrittori triestini e il Fascismo. Trieste: Italo Svevo, 1975.

Major, Patrick. Behind the Berlin Wall: East Germany and the Frontiers of Power. Oxford: University Press, 2010.

Mallett, Robert. Mussolini and the Origins of the Second World War, 1933-1940. New York: Palgrave MacMillan, 2003.

Malnati, Ettore. Antonio Santin: un Vescovo tra profezia e tradizione 1938-1975. Trieste: Mgs Press, 2003.

Mammone, Andrea. "A Daily Revision of the Past: Fascism, Anti-Fascism, and Memory in Contemporary Italy." Modern Italy 11(2) (2006): 211-226.

Mapelli, Marco. "La destra italiana e la Questione di Trieste (1946-1954): la ricerca di una rileggitimazione italiana." Quaderni Giuliani di Storia (2) (1987): 25-62.

Maranzana, Silvio. Border Crossing: Vecchi e Nuovi Intrighi Attraverso Trieste. Trieste: Hammerle Editori, 2001.

Mazower, Mark. Salonica, City of Ghosts:Christians, Muslims, and Jews 1430-1950. New York: Random House, 2006.

Mazower, Mark. Hitler's Empire: How the Nazis Ruled Europe. New York: Penguin Press, 2008.

McCourt, John. The Years of Bloom: James Joyce in Trieste, 1904-1920. Wisconsin: University Press, 2000.

McDermott, Kevin, and Matthew Stibbe. Revolution and Resistance in Eastern Europe: Challenges to Communist Rule. New York: Berg Publisher, 2007. 
Mellinato, Giulio. "Tra mercato e propaganda; la ricostruzione del settore marittimo nella Trieste del secondo dopoguerra."Acta Histriae 13(2) (2005): 447-460.

Meny, Yves. Populismo e democrazia. Bologna: Il Mulino, 2004.

Meyr, George, e Raoul Pupo. Dalla cortina di ferro al confine ponte: a cinquant'anni dal Memorandum di Londra, l'allargamento della NATO e dell'Unione Europea. Trieste: Edizioni Comune di Trieste, 2008.

Millo, Anna. La Difficile intesa. Roma e Trieste nella questione giuliana 1945-1954. Trieste: Italo Svevo, 2011.

Minca, Claudio. "Trieste Nazione and its Geographies of Absence." Social and Cultural Geography 10 (3) (2009): 257-277.

Misztal, B. “The Sacralization of Memory.” European Journal of Social Theory 7 (1) (7) (2004): 67-84.

Montani, Carlo. Il trattato di Osimo (10 novembre 1975). Firenze: Risma, 1991.

Monzali, Luciano. The Italians of Dalmatia:from Italian Unification to WWI. Toronto: University Press, 2009.

Moore, Bob. Resistance in Western Europe. New York: Berg, 2000.

Morgan, Philip. The Fall of Mussolini: Italy, the Italians, and the Second World War. New York: Oxford University Press, 2007.

Morris, Jan. Trieste and the Meaning of Nowhere. New York: Simon \& Schuster, 2001.

Nabradalik, Bartosz. "South-Eastern Poland between 1939 and the Final Soviet Frontier Demarcation in 1951-The Destruction of an Ethnic Mosaic." Journal of Slavic Military Studies 21(2008): 17-37.

Negrelli, Giorgio. Dopo il ritorno dell'Italia. Trieste 1954-1969. Scritti ed interventi polemici. Udine: Del Bianco, 1992.

Nello, Paolo. Trieste 1945-1954: Un sogno tricolore. Firenze: Alinari, 2004.

Nimni, Ephraim."Nationalism, Ethnicity, and Self-Determination: A Paradigm Shift?" Studies in Ethnicity and Nationalism 9 (2) (2009): 319-332.

Nuovo, Lorenzo e Stelio Spadaro (ed.). Gli Italiani dell'Adriatico orientale: esperienze politiche e cultura civile. Gorizia: Libreria Editrice Goriziana, 2012.

Pacini, Giacomo. Il cuore occulto del potere. Roma: Nutrimenti, 2010.

Pahor, Milan. "Sloveni e Italiani insieme nella liberazione della città di Trieste. L'azione del comando città di Trieste e di Unità Operaia." Qualestoria 31(1) (2006): 73-93.

Pallante, Pierluigi. La tragedia delle "foibe." Roma: Editori Riuniti, 2006.

Parlato, Giuseppe. Fascisti senza Mussolini: le origini del neofascismo in Italia, 1943-1948. Bologna: Il Mulino, 2006.

Parlato, Giuseppe. Trieste nella politica italiana (1945-1954). Trieste: Comune di Trieste, 2007.

Patriarca, Silvana. Italian Vices: Nation and Character from the Risorgimento to the Republic. Cambridge: University Press, 2010.

Pavone, Claudio. Una guerra civile: saggio storico sulla moralità nella Resistenza.

Torino: Bollati Boringhieri, 1991.

Pelaschiar, Libero. Edoardo Marzari: sacerdote in terra di confine. Brescia: Morcelliana, 2003.

Perfetti, Francesco, Andrea Ungari, Daniele Caviglia e Daniele De Luca (ed.). Aldo Moro nell'Italia contemporanea. Firenze: Le Lettere, 2011.

Petacco, Arrigo. A Tragedy Revealed: the Story of the Italian Population of Istria, Dalmatia, and Venezia Giulia, 1943-1956. Toronto: University of Toronto Press, 2005.

Picariello, Valentina. Politica estera e opinione pubblica. Il Trattato di Osimo. M.A. Thesis, University of Milan, 1996.

Pilotto, Stefano. La politica di non allineamento della Jugoslavia di Tito. Gorizia: Libreria Editrice Goriziana, 2008.

Pirjevec, Jozè. Niccolò Tommaseo tra Italia e Slavia. Venezia: Marsilio Editori, 1977. Pirjevec, Jozè, and Kacin Milica. Storia degli sloveni in Italia. Padova: Marsilio, 1999. 
Pirjevec, Jozè. Foibe: una Storia d'Italia. Torino: Einaudi, 2009.

Pizzi, Katia. A City in Search of an Author. London: Sheffield Academy Press, 2001.

Pupo, Raoul. Foibe. Milano: Mondadori, 2003.

Pupo, Raoul. Il lungo esodo. Istria: le persecuzioni, le foibe, l'esilio. Milano: Rizzoli, 2005.

Pupo, Raoul. Il confine scomparso: saggi sulla storia dell'Adriatico orientale nel Novecento.

Trieste: Irsml Friuli Venezia Giulia, 2007.

Pupo, Raoul."Fonti e Archivi." Quale Storia (2) (December, 2010): 7-79.

Rabel, Roberto. Between East and West: Trieste, the United States, and the Cold War, 19411954. Durham: Duke University Press, 1988.

Ramet, Sabrina. The Three Yugoslavias: State Building and Legitimation,1918-2005.

Washington: Woodrow Wilson Center Press, 2006.

Rebeschini, Monica. "Organigrammi e Carriere nel GMA dellaVenezia Giulia." In Dopoguerra di confine, ed. Tullia Catalan, Giulio Mellinato and Pio Nodari, 113-125. Trieste: Tipografia Adriatica, 2007.

Redivo, Diego. Le trincee della nazione: cultura e politica della Lega Nazionale (1891-2004). Trieste: LN, 2004.

Reill, Dominique.Nationalists who Feared the Nation: Adriatic Multi-Nationalism in Habsburg Dalmatia, Trieste, and Venice. Standford: University Press, 2006.

Riall, Lucy. Risorgimento:The History of Italy from Napoleon to Nation State. New York: Palgrave MacMillan, 2009.

Rizi, Fabio Fernando. Benedetto Croce and Italian Fascism. Toronto: University of Toronto Press, 2003.

Rocchi, Flaminio. L'Accordo di Osimo sulla zona B. Roma: ANVGD, 1976.

Romano, Sergio. Guida alla politica estera italiana. Milano: Rizzoli, 2002.

Romero, Federico, e Antonio Varsori. Nazione, interdipendenza e integrazione: le relazioni internazionali dell'Italia (1917-1989) Volume II. Roma: Carocci Editore, 2005.

Rossi, Elena Aga. Una nazione allo sbando. L'armistizio italiano del settembre 1943 e le sue conseguenze. Bologna: Il Mulino, 2003.

Rossi, Elena Aga e Victor Zaslavsky. Togliatti e Stalin: Il PCI e la politica estera staliniana negli archivi di Mosca. Milano: Il Mulino, 2007.

Rusconi, Gian Enrico (ed.). Nazione, etnia, cittadinanza in Italia e in Europa. Per un discorso storico-culturale. Brescia: Editrice La Scuola, 1993.

Sapelli, Giulio. Trieste italiana. Mito e destino economico. Milano: Franco Angeli, 1990.

Sartori, Chiara. Strong Identities: Localism and Nationalism in Gorizia. PhD diss., Brown University, 2012.

Savorgnan, Alvise. La verità su Trieste: una cronistoria, una denuncia, una proposta.

Trieste: Lint, 1980.

Scaliati, Giuseppe. Trame nere: i movimenti di destra in Italia dal dopoguerra ad oggi. Genova: Frilli Editori, 2005.

Schiffrer, Carlo. Le origini dell'irredentismo triestino (1813-1860).Verona: Del Bianco, 1978.

Setta, Sandro. La destra nell'Italia del dopoguerra. Roma: Editori Laterza, 1995.

Slapater, Scipio. Lettere triestine: col seguito di altri scritti vociani di polemica su Trieste.

Trieste: Edizioni Deadolibri, 1988.

Sluga, Glenda. The Problem of Trieste and the Italo-Yugoslav Border: Difference, Identity, and Sovereignty in Twentieth Century Europe. New York: State University Press, 2001.

Spazzali, Roberto. Contributi di ricerca per una storia della Lega Nazionale 1946: la ricostituzione. Trieste: Edizioni Trieste Press, 1987.

Spazzali, Roberto. L'Italia chiamò: resistenza politica e militare italiana a Trieste 1943-1947 Gorizia: Libreria Editrice Goriziana, 2003.

Spazzali, Roberto. Trieste di fine secolo (1955-2004). Per una storia politica del secondo novecento. Trieste: Edizioni Italo Svevo, 2006. 
Spazzali, Roberto. Volontari della libertà: dalla resistenza politica all'insurrezione armata: documenti e testimonianze. Udine: Del Bianco Editore, 2008.

Spazzali, Roberto. "Il secondo Risorgimento. Un riferimento non banale a Trieste."Risorgimenti d'Italia (2011): 1-19.

Spazzali, Roberto. Secondo irredentismo: tra patriottismo democratico e rivendicazione integrale dell'italianità sulla Venezia Giulia. Trieste: Università di Trieste, 2011.

Tamaro, Attilio. Storia di Trieste. Trieste: Edizioni Lint, 1976.

Tatò, Grazia. Gianni Bartoli e il suo tempo. Trieste: Deputazione di Storia Patria per la Venezia Giulia, 2011.

Taviani, Paolo Emilio. Politica a memoria d'uomo. Bologna: Il Mulino, 2002.

Taylor, Fred. The Berlin Wall: a World Divided 1961-1989. New York: Harper Collins, 2006.

Tobia, Simona. Advertising America. The United States Information Service in Italy (1945-1956). Milano: LED Edizioni Universitarie, 2009.

Tonel, Claudio. Dossier sul neofascismo a Trieste (1945-1983). Trieste: Edizioni Dedolibri, 1991.

Toninelli, Pier Angelo, Bianca Cuderi, Adriano Dugulin, Giulio Mellinato, e Annamaria Vinci. La città reale. Economia, società e vita a Trieste 1945-1954. Trieste: Comune di Trieste, 2004.

Tranfaglia, Nicola. La "Santissima Trinità." Mafia, Vaticano e servizi segreti all'assalto dell'Italia. Milano: Bompiani, 2011.

Udina, Manlio. Gli accordi di Osimo: lineamenti introduttivi e testi annotati. Trieste: Edizioni Lint, 1979.

Valdevit, Giampaolo. Trieste 1953-1954. L'ultima crisi? Trieste: OTE Spa, 1994.

Valdevit, Giampaolo (ed.). La crisi di Trieste: maggio-giugno 1945: una revisione storiografica. Trieste: Istituto Regionale per la Storia del Movimento di Liberazione nel Friuli Venezia Giulia, 1995.

Valdevit, Giampaolo. Trieste: storia di una periferia insicura. Milano: Bruno Mondadori, 2004.

Verrocchio, Ariella. Trieste tra ricostruzione e ritorno all'Italia (1945-1954). Trieste: Irsml, 2004.

Vetter, Cesare, e Andrea Stefanel.” Giuseppe Mazzini: felicità, reincarnazionismo e sacralizzazione della politica." Contemporanea: rivista di storia dell'800 e del '900. 14 (2011) (1) 5-32.

Vezzà, Andrea. Il C.L.N. dell'Istria. Trieste: Associazione delle Comunità Istriane, 2013.

Vezzà, Andrea, e Pietro Comelli. Trieste a destra. viaggio nelle idee diventate azione lontane da Roma: dalle origini del Msi alla svolta di An, dalla fusione nel Pdl allo strappo dei futuristi. Trieste: Battello Stampatore, 2013.

Vidali, Vittorio. Ritorno alla città senza pace, il 1948 a Trieste. Milano: Vangelista, 1982.

Vowinckel, Annette, Marcus M.Payk, and Thomas Lindenberger. Cold War Cultures: Perspective on Eastern and Western European Societies. New York: Berghahn Books, 2012.

Zuccari, Maurizio. Il dito sulla piaga: Togliatti e il Pci nella rottura fra Stalin e Tito 1944-1957. Milano: Nursia, 2008. 